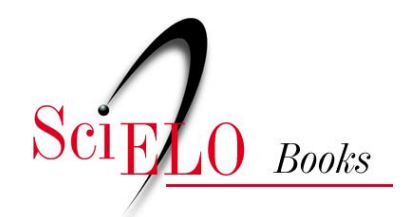

\title{
Seduepb
}

\section{Educação Universitária}

práxis coletiva em busca de veraz qualidade e de precisa cientificidade

\author{
Pedro Bergamo
}

\section{SciELO Books / SciELO Livros / SciELO Libros}

BERGAMO, P. Educação universitária: práxis coletiva em busca de veraz qualidade e de precisa cientificidade [online]. Campina Grande: EDUEPB, 2012. 295 p. ISBN 978-85-7879-189-6. Available from SciELO Books < http://books.scielo.org>.

\section{(2)(1)(2)}

All the contents of this work, except where otherwise noted, is licensed under a Creative Commons Attribution-Non Commercial-ShareAlike 3.0 Unported.

Todo o conteúdo deste trabalho, exceto quando houver ressalva, é publicado sob a licença Creative Commons Atribuição Uso Não Comercial - Partilha nos Mesmos Termos 3.0 Não adaptada.

Todo el contenido de esta obra, excepto donde se indique lo contrario, está bajo licencia de la licencia Creative Commons Reconocimento-NoComercial-CompartirIgual 3.0 Unported. 


\section{Universidade Estadual da Paraíba}

Profa. Marlene Alves Sousa Luna

Reitora

Prof. Aldo Bezerra Maciel

Vice-Reitor

\section{Aeduepb}

\section{Editora da Universidade}

\section{Estadual da Paraíba}

\section{Diretor}

Cidoval Morais de Sousa

Coordenação de Editoração

Arão de Azevedo Souza

\section{Conselho Editorial}

Célia Marques Teles - UFBA

Dilma Maria Brito Melo Trovão - UEPB

Djane de Fátima Oliveira - UEPB

Gesinaldo Ataíde Cândido - UFCG

Joviana Quintes Avanci - FIOCRUZ

Rosilda Alves Bezerra - UEPB

Waleska Silveira Lira - UEPB

\section{Editoração Eletrônica}

Jefferson Ricardo Lima Araujo Nunes

Leonardo Ramos Araujo

\section{Capa}

Arão de Azevedo Souza

Comercialização e Divulgação

Júlio Cézar Gonçalves Porto

Zoraide Barbosa de Oliveira Pereira

\section{Revisão Linguística}

Elizete Amaral de Medeiros

\section{Normalização Técnica}

Elisabeth da Silva Araújo 


\section{Pedro Bergamo}

\section{Educação Universitária \\ Práxis coletiva em busca de veraz qualidade e de precisa cientificidade}

\section{@eduepb}

Campina Grande/PB

2010 
Copyright $\odot 2010$ dos Organizadores

A reprodução não-autorizada desta publicação, por qualquer meio, seja total ou parcial, constitui violação da Lei n 9.610/98.

A EDUEPB segue o acordo ortográfico da Língua Portuguesa de 1990, em vigor no Brasil, desde 2009.

Depósito legal na Biblioteca Nacional, conforme decreto $n^{\circ}$ 1.825, de 20 de dezembro de 1907.

FICHA CATALOGRÁFICA ELABORADA PELA BIBLIOTECA CENTRAL - UEPB

378

B493e Bergamo, Pedro.

Educação universitária: práxis coletiva em busca de veraz qualidade e de precisa cientificidade/ Pedro Bérgamo. - Campina Grande: EDUEPB, 2010.

$296 \mathrm{p}$.

ISBN - $978-85-7879-055-4$

1. Educação Superior. 2. Educação - Aprendizagem. 3. Educação - Qualidade I. Titulo.

21. ed. CDD

\section{EDITORA DA UNIVERSIDADE ESTADUAL DA PARAÍBA}

Rua Baraúnas, 351 - Bodocongó - Bairro Universitário - Campina Grande-PB - CEP 58429-500 Fone/Fax: (83) 3315-3381 - http://eduepb.uepb.edu.br - email: eduepb@uepb.edu.br

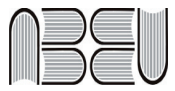

Editora filiada a ABEU 


\section{Nota dos editores}

Este livro deverá ultrapassar um mero ensaio, porque nele se encontram argumentos pouco ou nada comuns sobre caráter veraz de qualidade e sobre precisa cientificidade de certa educação universitária. Concomitantemente, e é o que mais importa, presume objeto de uma pedagogia que, a partir da sua autoafirmação enquanto práxis coletiva em ambiência acadêmica, há de enfim se tornar apta a romper com o vezo colonizador do seu humano campo de atuação.

Os argumentos, em questão, respondem, antes de tudo, a uma persistente inconformidade com a tirania das circunstâncias em que se processa o processo educativo. Resultam de uma mediada pesquisa-ação que houve de acontecer desde 2002 e, na atualidade, conta com um grupo de pesquisadores incondicionalmente voluntários sob a denominação de "CONSER" (ser junto) e com o beneplácito de servir-se da infraestrutura da Faculdade São Francisco de Barreiras (FASB), no oeste do Estado da Bahia.

A rigor, a autoria do texto é coletiva. Entretanto, ainda não tem sido possível dispensar uma mediação, a recair sobre um pesquisador educacional que, para tanto, não se furta a responder nominalmente por eventuais falhas expositivas dos referidos argumentos, inclusive porque anteriormente já assumira o desafio de investigar os fundamentos do objeto assim pesquisado, em nível de pós-doutoramento, junto à Faculdade de Educação da Universidade Estadual de 
Campinas (FE/UNICAMP), sob o título de "FILOSOFIA, EDUCAÇÃO E O MUNDO DO TRABALHO: a relação dialética presente no paradigma da sustentabilidade constituído na dinâmica entre apropriar e produzir e a implantação da pedagogia histórico-crítica como fundamento de um projeto político-pedagógico e institucional de formação superior emancipatório em Barreiras - BA (FASB)".

Desde a entrega dos resultados da investigação teórica, na FE/UNICAMP, até o encaminhamento do presente texto para publicação, avançaram inferências obtidas à base da práxis coletivo-experimental que passou a ser denominada "Autoaplicação da Proposta Pedagógica Fasbiana". Quanto, assim, a avançar, cumpre ter em vista não apenas corroboração das hipóteses originárias da investigação procedida junto à FE/UNICAMP, bem como intensificação dessa mesma práxis.

Peculiarmente, cumpre ressaltar oportuno apoio de pesquisadores das Universidades Estadual e Federal da Paraíba, assim como de voluntários paraibanos que, por exercerem docência na FASB na ária da Comunicação Social, têm sido assíduos frequentadores e, inclusive, corresponsáveis pela dinâmica do "CONSER". 


\section{Lista de siglas}

CES: Câmara de Educação Superior (Conselho Nacional de Educação; Ministério da Educação)

CIC: Congresso de Iniciação Científica (da Faculdade São Francisco de Barreiras)

CONAES: Comissão Nacional de Avaliação do Ensino Superior

CONSER: "Ser junto" (nome de grupo de pesquisa-ação da Faculdade São Francisco de Barreiras)

CPA: Comissão Própria de Avaliação.

ENADE: Exame Nacional de Desempenho de Estudantes

ENDIPE: Encontro Nacional de Didática e Prática de Ensino

FASB: Faculdade São Francisco de Barreiras (BA)

FE/UNICAMP: Faculdade de Educação da Universidade Estadual de Campinas

IAESB: Instituto Avançado de Ensino Superior da Bahia (Mantenedor da Faculdade São Francisco de Barreiras)

IES: Instituição de Ensino Superior

INEP: Instituto Nacional de Estudos e Pesquisas

Educacionais Anísio Teixeira 
LDB: Lei de Diretrizes e Bases da Educação Nacional MEC: Ministério da Educação

PAIDEIA (educação na Antiguidade Clássica grega): no caso, nome de grupo de pesquisa da Faculdade de Educação da Universidade Estadual de Campinas

POIETHOS (I): Simpósio Nacional sobre Política, Ética e Educação (Primeiro)

PUCRS: Pontifícia Universidade Católica do Rio Grande do Sul

SINAES: Sistema Nacional de Avaliação do Ensino Superior

UEPB: Universidade Estadual da Paraíba

UNEB: Universidade Estadual da Bahia

UFBA: Universidade Federal da Bahia 


\section{Glossário}

"Afetividade inequívoca" é o que se desvela como sociabilidade isenta de desejos interesseiros. É percebida na aparência corpóreo-pessoal, por conta da vivência das necessidades humanas, a começar pelas vital-básicas e da reprodução da espécie e, graças a essa vivência, acaba por determinar processo cerebral na perspectiva de este processo ser mediador por entre a exsurgência das necessidades e a sensibilidade para perceber o que as atende. Desequivocação da afetividade há de responder à valoração das necessidades por elas mesmas e a partir das vital-básicas e da reprodução da espécie. À medida que vier a ser vivenciada tal valoração, ficará evidente que a "afetividade inequívoca" co-fundamenta a dinâmica da individuação, a partir do âmago da subjetividade.

“Alteridade de concepção dialética" é o processar-se do pensamento cuja fonte esteja a assumir produção intelectual de modo inequívoco e opcionalmente empreendido e, por isso, se apoie em "incontinuidade", seja por entre a identidade a toda prova do "modo de existir "privacional" (dos objetos de desejo ainda irrealizado ou irrealizável) e as diferenças pelas quais se manifesta o "modo de existir "presencial"' (dos apropriados suportes das utilidades), seja por entre as abstrações correspondentes ao "modo de ser 'ausencial" " como teleconvergem entre si o sentido do exsurgir das necessidades vital-básicas e o sentido do exercício das funções que as atendem, seja ainda por entre as concepções da "afetividade" e da "vontade", ambas ao padecer desequivocação. 
"Alteridade institucional" coincide com a ocorrência do que é humanamente imprescindível, vale dizer, com o acontecer da produção inequívoca e opcionalmente empreendida. Se viesse a ser efetiva e, na medida disto, tal produção implicaria em reduzir o ônus sustentatório das vigentes instituições, ou seja, estas se tornariam menos absurdas ou menos supérfluas.

"Arrogância reivindicalista" é desvelada por atitudes e condutas, as quais desvinculam obrigações em relação a direitos e tendem a se intensificar junto a vítimas da irreflexa aquisição de conhecimentos fragmentados e fragmentários. Traduz conduta pseudoadulta, por usurpar o natural e frágil sentido do coletivo cujo fulcro é a espécie em reprodução ou a imaturidade naturalmente ainda autoinsustentável. A fonte de pseudoadultez humana não se dá conta de que viver já implica em ela estar remunerada, peculiarmente em espécie (alimentos, abrigo e condições de ir e vir no âmbito do coletivo). É-lhe irreconhecível que assumir atividades parcialmente gratuitas signifique limites para uma apropriação estritamente particularista, uma vez que produzir meios de vida também incide em limites singular-pessoalmente não ultrapassáveis.

"Avaliação também por produção" é constatação de aprendizagem pela qual se desvele singularidade pessoal-humana de forma que esta se explique por um excesso em sua autorreprodução e por destinar este excesso ao soerguimento do coletivo cuja suficiência há de justificá-la. Para tanto, há de escudar-se nos resultados concretos das suas atividades inequivocamente produtivas, os quais têm como refletir caráter único da correspondente fonte - outra fonte jamais os obteria com as mesmas características. 
"Autoridade educacional" significa, embora enquanto rito de passagem, reprovar ou aprovar um educando, mediante o ajuizamento de que, respectivamente, não produz ou produz de modo inequívoco. Nos casos concretos em que é gerada oportunidade de tal ajuizamento, cumpre ter em conta os graus de residual imaturidade ou de afluente maturidade.

"Criação da escassez" é o que resulta de apropriar, por além e à revelia de produzir, para atender à necessidade histórico-culturalmente engendrada de espontaneamente só valorizar o que garante plena e prévia certeza quanto a atender às necessidades vital-básicas, alheando-se, para tanto, à questão de critérios na escolha de meios e fins. Por si mesmas, as necessidades vital-básicas nada significam, tal como acontece com o exercício de funções próprias para atendêlas em reciprocidade de coerência com intercâmbio orgânico com a natureza livre. Autoentrega pessoal assim a valorizar não tem como prevenir excessiva aquisição de propriedades externas à pessoa e/ou desejo de acumulá-las ilimitadamente. Mas, suportes de propriedades têm limites físicos, cuja tácita inaceitabilidade desanda em desejos ainda não realizados e/ou irrealizáveis de expandi-los ilimitadamente. Acumulação efetiva de propriedades externas à pessoa perfaz um somatório cujo artifício corresponde ao número de propriedades multiplicado pela quantidade de seus proprietários, mas, ao mesmo tempo, um outro somatório astronomicamente maior, o qual perfaz os resultados da multiplicação de cada propriedade vezes todos os (seus) não proprietários. A diferença quantitativa entre o primeiro e o segundo desses somatórios incide em negatividade (carência ou privação), à qual cumpre adicionar aquela correspondente aos incontáveis e incomensuráveis objetos de desejos ainda não realizados e/ou irrealizáveis. Assim projetada, a negatividade detém "modo de existir 'privacional"' (vazio, imaterial, insensorial) que é próprio 
da escassez enquanto necessidade histórico-culturalmente engendrada cuja impossibilidade de pleno atendimento tem feito com que insuficiência de remunerações adentre enigma e inclusive mistério. Já inconformidade com tal insuficiência, a par da remediação de conflitos, tem incidido em ônus cuja cobertura houve de responder pelo inchaço de uma proporção dos preços das utilidades, inclusive daquelas que são imprescindíveis para a produção inequívoca se processar sem incidir no absurdo de sua fonte humana ter sempre mais de pagar e sempre menos de receber para encará-la.

"Crise da historização" vem a ser instabilidade ético-moral e institucional, a recorrerem no âmbito, respectivamente, da subjetividade e dos processos sociais originários no Ocidente e em vias de globalização. Deve-se ao acúmulo de eventos que decorrem de o ser humano precisar fazer guerra contra outrem e contra tudo, para não guerrear contra si mesmo ou contra as suas próprias interessenças, ainda que estas interessenças e ele próprio se evidenciem demolidores do sentido também coletivo da sustentabilidade. "Historização", enquanto implicadora de crise, é decorrência da autoentrega individualista e corporativista à dinâmica do desejo, desandando na "criação da escassez" e na acumulação de propriedades cuja disseminação gera incontavelmente mais problemas do que soluções.

"Crítico-teoria" vem a ser saída para avançar no questionamento da involuntariedade da inserção nas relações sociais de produção, avanço não consumado pela teoria crítica que se propõe, por tácito que o ocorra, a qualificar as humanidades. Tal questionamento se impõe, uma vez que a crítica de Marx, correspondente à inversão da dialética hegeliana, ainda não implicou superar, de uma vez por todas, o absoluto da ideia pelo absoluto do trabalho, dado que este e, tão só este, 
sempre houve de processar a sua própria divisão, além de que, subsumido à revolução proletária, ainda haveria de mudar a sua própria história. Na falta de tal avanço teórico-crítico, a concepção de trabalho tem incidido em acentuado esgarçamento, juntamente com o interesse emancipatório da espécie. Alterinamente, a imprescindibilidade de a pessoa ser parcial e opcionalmente gratuita no processo produtivo há de lograr que este mesmo processo se depure de equívocos e acabe por complementar o sentido emancipatório do trabalho na ortodoxia marxiana. "Crítico-teoria" também é o que resulta do pensar cuja fonte se depare por entre o sentido (de nascer e de subsistir tendo necessidades, as vitais-básicas antes das demais), e o absurdo (de criar escassez, à conta de apropriar, por além e à revelia de produzir, para atender a necessidade histórico-culturalmente criada de não valorizar as vitais-básicas, cujo atendimento tem incidido em desvalorização de outrem e da natureza, os quais padecem esse mesmo atendimento, sob pena de exclusão até mesmo fatal).

"Despossessão do coletivo natural-mínimo" é o que ocorreria, caso a pessoa humana vivenciasse, ao menos enquanto rito de passagem e no limiar da sua natural adultez, a situação de sustentar a si mesmo e a um ou mais dependentes, todos em total isolamento em meio à natureza livre. Em contraponto, ver: "Posse do coletivo natural-mínimo".

"Dialeticidade da razão" é pensar por entre existir e ser, ou seja, por entre, de uma parte, a oposição existente entre a diferença do "modo de existir "presencial"” e a identidade a toda prova do "modo de existir "privacional", e, de outra parte, teleconvergir por entre o exsurgir das necessidades vital-básicas e o provir das funções de as atender, ambos - exsurgir e provir - a procederem de origens antagônicas e sob "modo de ser 'ausencial"” (imperceptível nas respectivas 
intencionalidades). É pensar que incide em "incontinuidade" entre diferenças, entre identidades ou entre umas e outras, assim como efetivo ou potencial "contato" entre os suportes de diferenças e/ou identidades. É co-fundamental à unidade que, enquanto tal, presume ruptura entre seus co-fundamentos, anterior ou posteriormente à própria efetividade.

"Formação" tem como vir a ser concebida como capacitação da singularidade pessoal-humana a aperceber-se e a interpretar-se situada por entre dois sentidos diretamente sempre imperceptíveis ou que se encontram fenomenicamente ocultos. Para ambos esses sentidos deixarem de restar meros candidatos a teleconvergirem, urge que não mais ocorram mediados, tanto pela socrático-platônica dinâmica do desejo, quanto pela marxiana alienação no trabalho. Há de ocorrer como "'ausencial' forma de ser por entre sentidos", a começar por entre o sentido do exsurgir das necessidades vital-básicas e o sentido do provir das funções voltadas para as atender.

"Fundo do poço da injustificação" traduz esgotamento da esperança radical de haver melhores condutas no âmbito do que é totalizado pela conjunção de hegemonia política, de reducionismo econômico e de abstracionismo científico-técnico. Ausência de melhores condutas responde à circunstância de que sempre houve desconforto, para não dizer dolorosidade, para assumir produção em reciprocidade de coerência com intercâmbio orgânico com a natureza. A perspectiva de resultados, os mais amplos possíveis, sempre constituiu natural, quiçá divina, compensação por assumir esse desconforto. Todavia, esta compensação está a ser revertida em ônus, ao perfazer, por ocultado que ainda o precise subsistir, proporção do preço dos meios de produzir, à qual correspondem rendas devidas a estritas propriedades, ou seja, a direitos histórico-culturalmente criados (tributos e rendas 
privadas, destas deduzidos os tributos). Em consequência, a fonte humana de esforço produtivo adentra desânimo ou apela para o apropriar ideologizado como produzir, transferindo para outrem o seu próprio desânimo. Trata-se de tipicamente desumano componente da construção do absurdo. No limite da tendência ("fundo do poço"), o preço final de quaisquer utilidades seria totalmente explicado por tributos e demais rendas de estrita propriedade sobre resultados da produção, de tal forma que toda a renda pessoal teria que se destinar à compra de meios para produzir (a pessoa e a máquina-robô se equivaleriam, à medida que esta condição viesse a satisfazer a pessoa que a nada mais se dedicasse do que àquilo que gosta ou que lhe realize o pertinente desejo, a exemplo do imemorial e sempre ilimitadamente desejado exercício do poder de criar obrigações para os seus semelhantes).

"Historicidade" expressa possibilidade de mudança inerente a uma realidade singular-pessoal ou mesmo corporativa, mudança a se constituir em desapossamento de coletivos sempre mais complexos, a começar por aquele relativo ao natural-mínimo ou à incondicional dependência da sustentação advinda de outrem. Trata-se de mudança que, por irracional que sempre o tenha subsistido entre adultos, tem chegado a ser fonte de gratuidade para as novas gerações e para a suficiência de coletivos, inclusive alterinos e, por isso, ainda a serem mais complexos do que os ora vigentes.

"Historização" expressa a mudança a ser condicionada por excludente avanço em científica-tecnologia e por insistência em substituir originárias potencialidades subjetivo-humanas em favor de aquisições cuja origem é extrínseca à pessoa. Reflete autoentrega pessoal e organizacional à dinâmica do desejo, desandando na "criação da escassez" 
- na acumulação de propriedades cuja disseminação gera incontavelmente mais problemas do que soluções.

"Incontinuidade-contato" coincide com a unidade da qual perfazem co-fundamentos: (a) abstrações relativas a diferenças ou a identidades; (b) suportes real-concretos de diferenças ou de identidades; e, (c) nulidade da relação espaço-tempo por entre abstrações entre si irredutíveis " $\mathrm{e}$ " por entre os correspondentes suportes real-concretos entre si expostos a entrarem em contato, de forma que ambas as nulidades incidam em determinada conjunção ("e"), enquanto esta mesma conjunção se torna tão co-fundamental à unidade quanto esses suportes e aquelas abstrações.

"Individuação íntegra" é a singularidade pessoal-humana a se conduzir coerentemente com "sustentabilidade também coletiva", ou seja, parcial-gratuitamente contributiva para a suficiência de coletivos sempre mais complexos, mas a partir do natural-mínimo. Para assim se conduzir, passa por "despossessão do coletivo natural-mínimo", despossessão que atualiza o sentido da "maiêutica" socrática (processo operativo de uma parteira conjuntamente com o da parturiente) e que hoje acaba interpretável como desequivocação quanto a produzir, a ser dolorosamente padecida. Tal singularidade se desvelaria com "vontade inequívoca" (autoimpulsão para assumir "gratuidade"), "afetividade" (sociabilidade isenta de desejos interesseiros) e "inteligência interflexa" (por entre "vontade" e "afetividade", assim desequivocadas).

"Ínfero referencial" corresponde à situação, que é básica e inarredável, por entre assumir opcionalmente "gratuidade" e criação do absurdo da propriedade, esta enquanto matriz de incontavelmente mais problemas do que soluções e aquele a se desdobrar em sociabilidade alterina. 
"Inteligência interflexa" é o que se desvela como pensar por entre "vontade inequívoca" (autoimpulsão para assumir opcionalmente "gratuidade") e "afetividade inequívoca" (sociabilidade isenta de desejos interesseiros). Este pensar perfaz um momento da "dialeticidade da razão", o qual há de suprir insuficiência mediativa do "intelecto ativo" em relação ao "passivo" e ao "contemplativo" em Aristóteles.

"Intercâmbio material-comunicativo" é antídoto à sincrônico-topounicidade ou ao resultado da "criação de escassez". Para tanto, são-lhe presumidas oportunidades enquanto fissuras, brechas ou poros no bojo da onipresente apropriação do poder político e domínio econômico. "Gratuidade" subjetivo-humana vem a ser a fonte de tais oportunidades. No caso, criar escassez coincide com denegar, mediante inserção na propriedade, acesso a fontes de meios de vida, desde as pessoal-próprias ou subjetivas, até aquelas objetivas ou inerentes à natureza livre.

"Interdisciplinaridade" responde à necessidade ou ao problema de esta ou aquela pessoa chegar, antes de tudo o mais, à sua "individuação íntegra". Trata-se, então, de educar-se de modo inequívoco e opcionalmente empreendido. Todavia, educar-se só ultrapassa mera intencionalidade, porque há de existir sua própria utilidade, objetivo que é deflagrado ("interdisciplinarizado") pelo ensino do que seja produzir em contraponto a tão só apropriar, no âmbito de cada campo de atuação e à base da especificidade (fundamento de disciplina, ou de aspecto desta). Apesar de imprescindível, o mero ensino de tal discernimento é insuficiente. Atividades-fim ("trabalhos interdisciplinares") hão de existir e as correspondentes reais-concretizações têm como incidir no que fundamenta o sentido mesmo de uma "avaliação também por produção". 
"Lacuna metafísica" expressa irreconhecível inserção em vazio ou falta de algo que, real-concretamente, coincida com fim-começo ou começo-fim que é limítrofe, não apenas por entre duas ou mais subcategorias enquanto pensadas, como também entre cada uma destas e a categoria principal que corresponde à representação do todo, da unidade ou do próprio indivíduo. A propósito, vazio teria que ocorrer absolutamente indiferenciável, enquanto perfizesse estrita forma. Assim, sem a interveniência de "incontinuidade" (fim-começo ou começo-fim, os quais sejam limítrofes a categorias), torna-se inalcançável "pensar o pensamento" (filosofar). [É expressão cujo significado foi construído a partir de aventada interpretação do que se encontra esboçado em Williams (2000, p. 45-53), enquanto eventual tentativa de teorizar a forma em Platão].

"Maiêutica da vontade" coincide com "parir" (subtrair) o mover-se pessoal para fora da dinâmica do desejo, ou seja, ocorrência do dispor-se, opcionalmente, a gerar "gratuidade". Vem a ser a deflagração do processo de o ser humano e de a sociabilidade se tornarem íntegros.

"Necessidade superior" é aquela de contar, de antemão e garantidamente, com o atendimento das demais necessidades, a partir das vital-básicas e da reprodução da espécie, graças ao experto expediente de transferir, para outrem, a obtenção dos imprescindíveis meios em reciprocidade de coerência e de pertinência quanto à sustentabilidade também coletiva e ao intercâmbio orgânico com a natureza, livre e humana.

"Pagar para produzir" decorre de o preço final de quaisquer utilidades acabar sempre mais explicável por tributos e demais rendas de estrita propriedade, ambos - tributos e rendas - incidindo sobre resultados da produção, de tal forma que a renda pessoal tenha que se destinar em proporção 
crescente à compra de meios para tão somente produzir. É concomitante com a extirpação do caráter produtivo do trabalho e com a entronização de outro caráter, aquele de acentuada inserção em consumo sempre mais custoso e superfluamente esgotante do pensar.

\section{"Paradigma da insustentabilidade coletiva" é o} conhecimento sobre a criação das condições de se tornar inevitável que se questione a direta ou indireta detenção da propriedade das fontes dos meios de vida, externos à pessoa, como excludente critério de acesso aos resultados do processo de produção acentuadamente científico-tecnologizado. Esse questionamento tende a se tornar proibitivamente custoso, o que reforça seu princípio-motor, ou seja, uma espécie de inchaço da proporção compreendida por tributos e por outras rendas de estrita propriedade na determinação dos preços finais das utilidades. Tal reforço decorre de aumentos de tributos que somente se tornam viáveis com sinalização institucional de variações positivas na taxa de rentabilidade privada.

\section{"Paradigma da sustentabilidade também coletiva"} é o conhecimento de que é imprescindível ou alternativamente institucional que ocorram sobras da produção fora da propriedade das correspondentes fontes. Sobras geradas no âmbito da propriedade singular-pessoal de outrem incidem na reprodução do "paradigma da insustentabilidade coletiva". (O sentido do coletivo, tendo por fulcro a prole ainda autoinsustentável, coincide com a condição do que é devoluto, vale dizer, a criança ignora, enquanto abstração, que possui ou que seja posse de outrem).

"Posse do coletivo natural-mínimo" vem a ser a condição ainda autoinsustentável da prole, cuja subsistência há de estar a cargo de outrem, até que naturalmente se esgote tal 
condição. A prole incorpora, paradigmaticamente, o sentido do coletivo, por sua fragilidade ou por contar incondicionalmente com outrem. Assim, ela perfaz suporte deste sentido, que, por sua vez, significa não se fazer por si mesmo ou não ter como coincidir com a fonte do que há de constituí-lo.

"Razão material-comunicativa" é percebida objetivadamente ou fora da subjetividade, além de coincidir com intercâmbio por entre um dilema de subsistência e uma questão disputacional. O dilema compreende opostos: o bem-estar individual e geral, que ora é vivenciado, teria como ser possível à conta dos resultados de uma inauditamente reduzida parte do esforço que vem sendo despendido sob sujeitação, ou alterinamente, seria várias vezes maior, se o mesmo esforço contasse com fissuras, brechas ou poros para ser exercido parcial-opcionalmente gratuito. A questão comunicativa tem a ver com o quase-impasse em que se insere a percepção dos teores desses opostos em disputa, pois a tentativa de comunicá-los se depara com desinteresse de quem mais necessita de os perceber e interpretar.

"Relação entre prole e quem, direta ou indiretamente, a sustenta" corresponde ao real-concreto cujo processar-se traduz a "sustentação também coletiva" no âmbito domiciliarmente natural-mínimo. Adulto(s) assume(m) atividades subsistenciais por além do que o faria(m) apenas por si mesmo(s), garantindo a perpetuação da própria espécie. É precisamente o que constitui real-concretamente esse "por além" ("gratuidade") que não se desenvolveu na espécie humana, ao passo que subsumir irracionalidade em tal mister acabou no que, de forma ainda não qualificada, permaneceu meramente espontâneo nas humanidades - a relação em causa não se tornou objeto fundante de ciências humanas. Os teores dessa relação perfazem um paradigma cujo substrato-chave 
há de incidir em desapossamento, ético-educacionalmente mediado, de coletivos progressivamente mais complexos.

"Situação epistêmica" trata-se do apoio do observador ainda imaturo (naturalmente ainda autoinsustentável). Tal apoio sempre incidiu em uma irreconhecível insignificância para quem assim se apoia, uma vez que coincide, seja com um inexpressivo ponto dentre incontáveis outros na totalidade real-concreta, seja com a circunstância de se estar do lado de fora de toda especificidade. Tal "situação" tem feito com que esta especificidade não passe de uma totalidade cujos componentes interiores permanecem não observados, além de conterem residuais incertezas quanto a possíveis influências na totalização. Também significa levitar propriedades extrínsecas à pessoa como instrumento de se garantir autossustentação.

"Trabalho interdisciplinar" é a execução de uma atividade pessoal ou grupalmente empreendida, ao menos como "rito de passagem" quanto a produzir de modo inequívoco, execução na qual teleconvergem duas ou mais disciplinas. Assim, a aplicabilidade de teores disciplinares passa a ser aquilatada em um único produto que, desde ao ser projetado, confere sentido também operacional às especificidades dos conteúdos de ensino.

"Vontade inequívoca" é o que se desvela como autoimpulsão para assumir "gratuidade" em reciprocidade de coerência com direto ou indireto intercâmbio orgânico com a natureza livre. 



\section{Sumário}

Introdução

\section{I.Prática sócio-seletivista de uma educação universitária}

A.Contextualização histórica junto

à exclusão continental e nacional

B.Situação local-regionalmente interiorizada. 58

C.Mediação pelo "paradigma da insustentabilidade coletiva".

\section{II.Problematização quanto a qualidade}

A.Concomitância de imprecisão sobre qualidade e de ameaça vinculada à obrigatoriedade de avaliação externa

B.Concepção de qualidade, heteronomicamente exposta a disputas ideológicas

1.Imprecisões da qualidade sob disputa

2.Procedimentos autoavaliativos: do alcance estratégico ao caráter "crítico-teoricamente" autoafirmativo

3.Alteridade de argumentação quanto à institucionalidade avaliativo-educacional

C.Cientificidade da pedagogia - síntese de um problema ainda em aberto 


\section{III.Instrumentalização para a busca de veraz}

qualidade e de precisa cientificidade da educação a promover

A.A notícia sobre uma situação real-concretamente básica e inarredável

B."Historização" enquanto "paradigma da insustentabilidade coletiva"

1.Absurdidade em construção

2.Perspectiva de "crise da historização" e seus dois horizontes mais visíveis

3.Questões alternativamente inadmissíveis

C.Especificidade dialética

1. "Forma por entre opostos" inerente ao real-concreto da dinâmica do desejo

2."Forma mediativo-configurativa" por entre os sentidos da exurgência das necessidades vital-básicas e do mover-se das funções que as atendem

3.Avanço coerente com a história da dialética por entre opostos

D.Categorias fenomenicamente compreensivas do que está escondido sob o que está manifesto......151

IV.Catarse pedagógico-propositiva

A.“Crítico-teoria” a descondicionar percepção e interpretação do fenômeno pedagógico

B.Autoconcepção da pedagogia na inteiridade da ambiência acadêmica.

1.Alternativas e alteridade quanto a fundamentar a pedagogia

2.Desconstrução da presumida e imprecisa qualidade da educação.

3.Autoconstituição da práxis educativa.

4.Ultrapassagem de equívocos quanto a identificar faculdades humanas. 
C.Projeto pedagógico, a abrir-se à

própria alteridade

1."Alteridade de concepção dialética" de ser humano e de sociabilidade.

2.Práxis coletiva, conexa à "interdisciplinaridade"

e à "avaliação também por produção"

3.Às costas da pós-modernista "atitude limite".

D.Qualidade e cientificidade da educação a promover.

V.Das percepções sincréticas à síntese

A.Autoridade educacional e a questão do valor intangível da liberdade.

B.Uma "pequena narrativa" da

(in)-justificação das instituições vigentes

C.Projeto político-pedagógico

1.Projeto enquanto opção inerente

à própria concepção.

2.Sentido propositivo-pedagógico de transitar por entre política e ética

3. “Alteridade institucional”: proteção à fragilidade da autoafirmação propositivo-pedagógica

4.Síntese dialeticamente arrazoada. 249

\section{Educação universitária em Barreiras} e no extremo-oeste da Bahia 253

A. Missão 253

B. Objetivos 256

C. Resultados alcançados 258

Considerações finais 279 



\section{Introdução}

Os teores do texto, a seguir, correspondem a resultados de uma pesquisa-ação, os quais entraram em fase de serem expostos à validação em alcance também intersubjetivo e externamente à práxis educativo-coletiva em cujo âmbito serão ainda mais aprofundados.

A deflagração das investigações remonta ao ano de 2002, no momento em que se tornou relevante a uma instituição de ensino superior (IES) ${ }^{1}$, isolada e interiorizada, buscar apoio para desenvolver atividades de pesquisa, as quais viessem a favorecer sua autoafirmação local-regional, mediante qualidade e rigor científico da educação a ser promovida. Nesta mesma perspectiva, passou a sediar, anualmente, um Congresso de Iniciação Científica (CIC), junto com "Encontro de Educação" e "Simpósio de Saúde".

No processar-se dessas iniciativas, emergiu oportunidade de ser noticiado, a um palestrante do II Encontro de Educação, o objeto da mencionada pesquisa, assim como alguns resul-

1 Trata-se da Faculdade São Francisco de Barreiras (FASB). A cidade de Barreiras se situa no extremo oeste do Estado da Bahia. (À frente, em I. A, será brevemente visto o significado sócio-histórico e geográfico dessa cidade e, notadamente, da cultura que a caracteriza). 
tados já obtidos ou previstos ${ }^{2}$. Concomitantemente, veio à tona a necessidade ou, segundo Saviani (2004, 10-16), o problema de como aquilatar, junto a uma reconhecida instituição educacional, o eventual alcance científico desse objeto, a par do sentido da qualidade da educação que nele se prenunciava. Aventou-se, ainda, a possibilidade de tal aquilatação ocorrer junto ao programa de pós-graduação da Faculdade de Educação da Universidade Estadual de Campinas (FE/ UNICAMP). Para tanto, um determinado mediador deveria frequentar o referido programa, no nível de pós-doutorado.

Essa possibilidade foi gradativamente amadurecida, no sentido de aproximar, entre si, o caráter pioneiro e já notório de pesquisas centradas na concepção dialética da educação na FE/UNICAMP e o caráter educativo-coletivo de uma específica e situada práxis na IES em apreço. Nesta, entrementes, uma proposta educacional que emergia da pesquisa-ação passara a ser admitida em um horizonte de possíveis aplicações da pedagogia histórico-crítica, cujo mais reconhecido protagonista - o educador e pesquisador Dermeval Saviani compõe a equipe de professores da FE/UNICAMP. Ademais, a própria pesquisa-ação já estava a se prenunciar como saída metódica para empreender busca de veraz qualidade e precisa cientificidade da educação universitária a ser interioranamente promovida.

Em decorrência e após a apresentação de um programa de estudos, assim como de alguns acertos institucionais, a

2 Em 2006, por ocasião do II Encontro de Educação, o Dr. César A. Nunes, professor-pesquisador da Faculdade de Educação da Universidade Estadual de Campinas (FE/UNICAMP), aceitou convite para proferir palestra sobre "A Formação do Educador: Desafios e Perspectivas". Após esse evento e durante o longo percurso de automóvel, ao retornar de Barreiras para Brasília, entrou em pauta a referida proposta educacional e sobre ela foi estabelecido um incipiente, mas profícuo diálogo. 
proposta educacional da referida IES, tendo por fulcro o caráter coletivo da pertinente práxis pedagógica, veio a se expor à crítica na pós-graduação da FE/UNICAMP. Paralelamente, na própria IES, a autoafirmação da pedagogia passou a contar com inusitado apoio gerencial-institucional, tendo-se em conta a fragilidade que é própria de quem assume responsabilidades educacionais.

Logo a seguir foi constituído um grupo de pesquisa-ação na própria IES $^{3}$, no qual passou-se a refletir, na medida do possível, sobre os reais fundamentos do caráter coletivo da práxis pedagógica em implementação, tendo por espelho o proceder dialético e os avanços teóricos, os quais caracterizam o grupo de pesquisa em filosofia da educação denominado PAIDEIA junto à FE/UNICAMP.

Entrementes, no contexto da práxis educativo-coletiva junto à IES e por intuitivo que ainda o fosse, deixara de constituir despropósito anuir a certa abertura para questionar a marxiana involuntariedade da inserção das fontes humanas de trabalho nas relações sociais de produção, a começar pela produção de serviços educativos. A inaugural intuição da possibilidade desse questionamento deveu-se a questões evocadas nas entrelinhas da tese de Mello (1982), especificamente quanto à potencialidade de a competência técnica nas atividades educativas motivar compromisso político ${ }^{4}$. Já anteriormente ao que veio a ser sugerido pela leitura daquela tese, estava a se consolidar determinada dúvida nos contrafortes da

3 Este grupo veio a se intitular "CONSER" ("ser junto"). Tem havido reunião mensal, em dois momentos. A frequência se caracteriza por ser opcional e é aberta a docentes, discentes, funcionários.

4 A partir de uma determinada crítica, conforme Nosella (2005), a tese em causa acabou por provocar acirradas disputas entre educadores. Estas mereceram mediação de Saviani (2005, p. 23-64), que, posteriormente, veio a formular "onze teses sobre educação e política" (2007, p. 81-91). 
pesquisa-ação. Deve-se esta dúvida à circunstância de a investigação estar a ocorrer mediada pelos teores referenciados sob o título de "paradigma da insustentabilidade coletiva". Por seu turno, esta mediação era dinamizada por um curso voltado para aperfeiçoamento da docência ${ }^{6}$, o que favoreceu percepção e interpretação dos fundamentos da mencionada involuntariedade e de implicações da pertinente reprodução.

Em contraponto a esses fundamentos, foi possível aventar hipóteses, ao menos isto, a respeito da emergência de uma necessidade, aquela de se promover, na educação de nível universitário e a favor da dinamização do seu processo, determinado descondicionamento do pensar em pedagogia, uma vez que o (contraposto) condicionamento teria a ver com omissão educacional de não prevenir o que, em insustentabilidade coletiva, veio a ser admitido como "posse do coletivo

5 Trata-se da criação das condições de se tornar inevitável que se questione a direta ou indireta detenção da propriedade das fontes dos meios de vida, externamente à pessoa, como excludente critério de acesso aos resultados do processo de produção acentuadamente científico-tecnologizado. Tal questionamento tende a se tornar proibitivamente custoso, o que reforça seu princípio-motor, ou seja, a proporção compreendida por tributos e por outras rendas de estrita propriedade nos monetizados preços finais das utilidades. Os teores deste princípio-motor foram publicados em uma coletânea de alcance internacional, conforme Bergamo (2007). Tentativamente, esses mesmos teores já haviam sido registrados, a título de divulgação entre eventuais leitores, em duas etapas da pertinente elaboração: BERGAMO, P. Atalhos para a equidade. Brasília: SEDAEX, 1997. (mimeo); BERGAMO, P. Autovaloração humana e (in)sustentabilidade global: uma investigação teórico-crítica sobre a relação entre devida adultez humana e presumido respeito à natureza. Barreiras/BA: FASB/ COTEB, 2001.

6 O referido curso de extensão foi intitulado "O Alcance Interdisciplinar da Relação Produção/Sustentabilidade (em Educação)”, resultando em um texto intitulado "Livro dos Docentes" e que acabou sendo enviado ao MEC, entre os apêndices do relatório de autoavaliação institucional, correspondente ao ano acadêmico de 2005. (A propósito ver: IAESB/FASB/CPA. Relatório Final. Barreiras/BA: CPA/FASB, 2006. Apêndice 2). 
natural-mínimo"7, a se perpetuar por além do período que a própria natureza determina à prole humana. Em outros termos, trata-se da hipótese de não acontecer, em tempo oportuno e em bases propriamente culturais, "despossessão" desse mesmo coletivo ${ }^{8}$.

As expressões entre aspas têm por fundamento real-concreto os teores da relação entre prole ainda autoinsustentável e quem, direta e/ou indiretamente, a sustenta. Trata-se de relação cujos teores têm sido marginalizados, informalizados e sócio-subjetivados, juntamente com a oportunidade de analisá-los. Todavia, por força do seu significado em humanidades, tal relação passa a ser o suporte real-concreto de toda a investigação. Por isso, a correspondente expressão aparecerá, doravante, entre aspas, além de motivar, ao longo do texto, certa proliferação de outras também assim entre aspas, a par

7 "Posse do coletivo natural-mínimo" vem a ser a condição ainda autoinsustentável da prole, cuja subsistência há de estar a cargo de outrem, até que naturalmente se esgote tal condição. A prole incorpora, sinteticamente, o sentido do coletivo, por sua fragilidade e/ou por contar incondicionalmente com outrem. Assim, ela incide na vicariedade deste sentido que, por sua vez, significa não ter como coincidir com a fonte do que há de constituí-lo.

8 "Despossessão do coletivo natural-mínimo" é o que ocorreria, caso o indivíduo vivenciasse, ao menos enquanto rito de passagem e no limiar da sua natural adultez, a situação de sustentar a si mesmo e a um ou mais dependentes, todos em total isolamento em meio à natureza livre. Mas, dada a efetiva e (histórico-culturalmente criada) impossibilidade dessa vivência, tem emergido oportunidade para a vigente sociabilidade se caracterizar pela preferência de transferir, para outrem, o atendimento das necessidades próprias, inaugurando-se, na própria subjetividade humana, o fenômeno da dominação política, a coincidir com aquele da divisão social do trabalho. Por sua vez, a efetivação dessa transferência desanda no problema cultural da criação da "necessidade superior", ou seja, aquela de contar, de antemão e garantidamente, com o atendimento das necessidades básicas e da reprodução da espécie, recorrendo-se, para tanto, ao experto expediente de transferir, para outrem, a obtenção dos imprescindíveis meios e a condição de tal recurso ter de assumir reciprocidade de coerência com sustentabilidade também coletiva e com intercâmbio orgânico com a natureza, livre e humana. 
de numerosas notas de rodapé. [No caso de ser necessário recordar o significado de uma ou outra de tais expressões, em número de trinta e uma, está disponível um glossário que consta já ao início do texto e que está compilado em ordem alfabética do primeiro termo.

À luz dos teores da referida relação, urgiria desmarginalizar, formalizar e sócio-objetivar que a sustentação da prole implique em alguém assumir atividades, e/ou resultados destas, por além ou em excesso do que o faria apenas por si mesmo e que, em rigor, esse excesso é gratuito por ter de emergir no exterior da propriedade da sua fonte. Alternativamente a tal geração, entende-se que esse excedente esteja a ocorrer de modo inescapavelmente forçoso, incidindo-se no recorrente pressuposto de a prole, tal qual seus progenitores, ser incapaz de emancipação, a partir da material-autossustentatória.

Na trama dos relacionamentos a se processarem no âmbito do coletivo natural-mínimo, torna-se inferível, no caso da sustentação própria e da prole, o que seja um inequívoco produzir, pois este implica atividades, e/ou resultados destas, parcialmente no exterior da propriedade singular-pessoal das pertinentes fontes. Por atender, ademais, as necessidades da reprodução da espécie - esta representada, tão só nesta circunstância, pela prole - há como a pessoa se explicar e ser justificada. Explica-se, porque seu produzir só é concebível, à medida que parte dos resultados se destina ao coletivo ou à perpetuação da própria espécie. Inversamente, é justificado porque o coletivo sequer subsistiria sem a contribuição da parte.

Produção e apropriação se equivalem no todo histórico-culturalmente criado, de tal forma que indiferenciá-las significa imaturidade natural-humana a ser vicária do próprio todo e a se perpetuar como usurpadora da condição de "posse do coletivo natural-mínimo". Aém disso, alcance inequívoco 
do que seja apropriar também procede da "relação entre prole e quem, direta ou indiretamente, a sustenta". Assim, apropriar é inequívoco, se a pessoa-parte não gera produção equivalente ao necessário à própria subsistência, sendo procedente apenas no caso de incapacidade natural (criança e portador de necessidades especiais, inatas ou supervenientes, como a invalidez e a senilidade).

À base dos teores inerentes à relação em causa, há como emergir "discernimento entre apropriar e produzir" que, paralelamente, acompanha o que passa a ser reconhecido como "paradigma da sustentabilidade também coletiva". Esta expressão, por seu turno, traduz-se na circunstância de ser imprescindível ou alternativamente institucional a ocorrência de sobras da produção fora da propriedade das correspondentes fontes.

Por força de tal institucionalidade, chega-se a uma outra expressão que veio a ser denominada "crítico-teoria" e que se reporta a incondicionamento do pensar, após a descoberta de que a vigência do "paradigma da insustentabilidade coletiva" sempre significou usurpação marginalizadora, informalizadora e sócio-subjetivadora dos excedentes destináveis à reprodução da espécie ${ }^{9}$. Em decorrência, esta reprodução continuaria a ocorrer à conta da irracionalidade que é inerente ao meiocomportamental, restando admissível que o nascimento do ser humano se deva ao acaso e que seu futuro há de depender do caos. Nasceríamos necessariamente em excesso e, por isso, de antemão disputantes de espaços vitais, mesmo que apenas

9 A inversão da dialética hegeliana por Marx implicaria superar, de uma vez por todas, o absoluto da ideia pelo absoluto do trabalho, dado que este e tão só este teria coincidido com o processo da sua própria divisão, além de que, subsumido à revolução proletária, haveria de mudar sua própria história. Na falta dessa mudança, “(...) depreende-se que o tema do trabalho é hoje muito polêmico sobretudo porque o debate a seu respeito assenta sobre dubiedades a respeito do que efetivamente se entende por trabalho" (GOERGEN, 2001, p. 22). 
dois de nós ocupássemos todo o Planeta, tirante à analogia bíblica da expulsão do paraíso. Ilustra-se tal incondicionamento do pensar, à base das três seguintes inferências: (a) a falta do excesso de atividades, e/ou de resultados destas, no exterior da propriedade individual e/ou organizacional tem impedido concepção dialética do sentido do que seja propriamente bem-comum - sentido que é inalienável à educação; (b) efetividade desse sentido presumiria contrapartida, opcionalmente assumida, de meios subsistenciais; entretanto, na ausência desta contrapartida emerge o problema ou a necessidade de impingi-la a outrem, a par de que a apropriação desta mesma necessidade é o que (pseudo)-fundamenta as relações sociais vigentes, assim como as instituições que lhes garantem a reprodução, a começar pela instituição educacional; e, (c) dado o vazio de tal sentido, a educação se converte na grãvilã do conservadorismo, à conta de sua omissão em assumir e promover "discernimento entre apropriar e produzir", o que equivale a não denunciar e fazer com que se torne inercial a extemporânea "posse do coletivo natural-mínimo".

Análise e síntese, assim entendidas, vêm a ser instrumentação que é imprescindível para prevenir ambiguidades dos termos sob os quais acaba subsumido o coletivo natural-mínimo (família, domicílio e escola). Ademais, ambas - análise e síntese - facultam, não só projeção de objetos de saber tão duradouros e concretos quanto a própria espécie humana, como também surpreendente questionamento do método em economia política, ou seja, ao suporte procedimental em que se apoia o fulcro da involuntariedade da inserção das fontes humanas de trabalho nas relações sociais de produção, vislumbrando-se, inclusive, "alteridade institucional" a abrir horizontes de questionamento de tal involuntariedade, a partir daquela das fontes humanas de trabalho educativo. Então, 
a partir de questionamentos assim abertos, tornou-se sempre mais justificado o caráter coletivo da práxis pedagógica ${ }^{10}$.

Com efeito, as escolhas ou eleições de conteúdos têm presumido inseparabilidade, entre política, epistemologia e economia, a condicionar o significado dos currículos, perfazendo-lhe ponto cego, peculiarmente no âmbito do ensino superior cujo sentido universitário lhe é, por isso, boicotado. Já este boicote, ponderada a inesgotabilidade das referências a pesquisar, vem incidindo em determinada omissão. Esta, na totalidade real-concreta do processo educativo, passa a estar "crítico-teoricamente" apontada como preventiva de primordialidade da ética que, por sua vez, precisaria se "historicizar"11 antecipadamente a ciências, para ambas se configurarem como estética no perfil do egresso de um processo antes humanizador do que educacional.

No âmbito desse processo humanizador, veraz qualidade e precisa cientificidade da educação universitária hão de corresponder ao fundamento real-concreto da "relação entre prole e quem, direta ou indiretamente, a sustenta". É que subjaz omissão em inverter autoinsustentabilidade na "historicidade" pessoal dos atuais educadores e dos educandos, uma

10 A vivência do caráter assim coletivo da práxis pedagógica foi tema de uma "sala de conversa", inserida na programação do XIV ENDIPE (Encontro Nacional de Didática e Prática de Ensino) que ocorreu no período de 27 a 30 de abril de 2008, na Pontifícia Universidade Católica do Rio Grande do Sul (PUCRS).

11 O termo "historicização" assume conotação peculiar ao longo do texto. Expressa mudança que é inerente a uma singularidade pessoal que ultrapassa a "posse do coletivo natural-mínimo" (incondicional dependência de quem a sustenta) e chega, por irracional que sempre o tenha subsistido junto a presumidos adultos, a ser fonte dessa mesma "posse" para as novas gerações. Estas, por sua vez e ao longo da inicial e finita autoinsustentabilidade, hão de passar pela mesma mudança, ou seja, por aprendizagem de como sustentar tal coletivo por além do que virão a fazer por elas mesmas. Já esta aprendizagem há de incidir em gradativa "despossessão" deste mesmo coletivo. 
vez que o processar-se desta mesma "historicidade" se inicia como "posse do coletivo natural-mínimo" e precisa terminar como possibilitação desta mesma "posse" para as novas gerações, por irracional que isto sempre tenha subsistido junto a presumidos adultos e ao longo da inicial e finita autoinsustentabilidade de cada um e de todas as pessoas.

Para chegar a ser fonte de tal possibilitação, toda singularidade humana ainda autoinsustentável há de passar por cultural "despossessão do coletivo natural-mínimo", vale dizer, por aprendizagem de como sustentar este coletivo, por além do que o fará para si própria, objetivo cuja implementação ainda tem sido postergada, moral e eticamente, a partir do miolo do processo educativo. Isto configura uma omissão a se traduzir como alheamento ao que cabe ser tratado como autoentrega de cientistas à confusão entre apropriar e produzir, o que os faz vitimar-se a inercial autoinsustentabilidade, inclusive na esfera das suas estritas pessoal-singularidades.

Assim, omissão educacional tem coincidido com inercial e antiética autoinsustentabilidade de pessoas (que são tidas) por adultas $^{12}$, vale dizer, com "posse do coletivo natural-mínimo" por além do que a própria natureza o determina, criando-se cultura como antinatureza, artifício ou dominação.

12 Sintoma de tal (pseudo)-adultez reside na raridade, para não dizer ausência, dos quatro seguintes questionamentos: “(1) Por que, sempre e em toda parte, nenhuma importância é dada à certeza de que cada uma e todas as pessoas capazes de autossustentação estejam mais a contribuir do que a se beneficiarem, a respeito da (re)-produção do bem-estar geral? (2) Por que a pessoa mesma não estabelece e divulga critério próprio de chegar a essa certeza? (3) Por que, em todos os casos, a falta dessa certeza precisa ser contornada pelo arbitrio do outro (do dono do micropoder, do proprietário de meios de vida, da autoridade legal, até chegar à divindade, cuja não aparência faz tudo voltar ao começo dos começos)? (4) Quem seria o outro do outro, um mistério?” (FASB/DA, 2006, mimeo. Grifos no original). 
Em decorrência, cabe propor razão para a ética anteceder ciências em determinado processo "crítico-teoricamente" humanizador, em vez de continuar-lhes posteriorizada no plano principal dos componentes do processo educativo.

Ética e autoafirmação pedagógica, por ainda hipotético que se o admita, tendem a se imbricarem, graças à referência do que seja produzir no âmbito incontestavelmente universal e objetivo da "relação entre prole e quem, direta ou indiretamente, a sustenta". Ambas - ética e autoafirmação - terminariam por coincidir com inequívoca produção de serviços educativos, ou seja, adentrariam coerência de condutas com sustentabilidade também coletiva.

Em desfecho, haveria alteridade de suporte procedimental para o indivíduo se explicar como fonte de possibilitação de coletivos mais complexos que o natural-mínimo e a realconcretização destes coletivos coincidiria com justificação da própria e também complexa pessoal-singularidade. E ambas - explicação e justificação - facultariam à ética preceder ciências no plano principal dos componentes do processo "crítico-teoricamente" humanizador ${ }^{13}$.

As colocações acima explicitadas constituem ponto de partida para acessar os teores do texto à frente elaborado. Esta elaboração, por sua vez, não chegaria a termo não fossem mediações que, ético-politicamente, influenciam a inescapável eleição dos diversos aspectos do objeto sob pesquisa-ação. Assim, cumpre alertar o leitor a respeito dessas mediações cuja pré-ciência há de facilitar a leitura.

13 Circunstancialmente, o significado dessa precedência veio a coincidir com o evento do "I POIETHOS - Simpósio Nacional sobre Política, Ética e Educação", ocorrido entre 11 e 13/06/2008, nas dependências da FE/UNICAMP. 
Dentre elas, há a própria - a educação, ela mesma, a perfazer mediação - e aquelas da concepção de mais-valia, conforme exemplificada por Max em "O Capital” (1984, p. 246), e da percepção de que é imprescindível ou institucional a geração de "gratuidade", forçosa ou opcionalmente.

Pedagogia veraz e cientificamente educativa não tem como prescindir de objeto de per si mediador. Mas chegar a este objeto depende de serem desnudos os teores que têm ficado escondidos à conta da omissão quanto a não desapossar o educando do coletivo natural-mínimo, ou seja, quanto a retardar, para não dizer sonegar, o acesso do alunado ao discernimento entre apropriar e produzir. Vislumbra-se que tal acesso há de induzir os egressos à certeza do que é errado e do desafio de assumir o que é certo, em matéria de relações sociais, a começar por aquelas de produção.

Quanto à concepção de mais-valia, previne-se recurso à conceituação contida em "Salário, Preço e Lucro" (MARX, 1983, p. 62-65), cujas rubricas se circunscrevem tão somente a instituições de direito privado e, como tais, voltadas para a realização de lucros em sentido restrito. Prefere-se aquela exemplificada em "O Capital” (MARX: 1984, p. 246) e cujas rubricas ficaram para ser posteriormente analisadas. Tal conceituação da mais-valia, além de conter a anterior, abrange também tributos. Tem sido usual silenciar sobre esta outra concepção, inclusive em textos de inspiração crítica. É que as implicações de um tal silêncio não se restringem a meros detalhes metodológicos, uma vez que a inclusão dos tributos na mais-valia atinge, às costas, a qualidade de determinada educação política e, de roldão, a qualidade da educação na sua integridade. É que tributação é inconciliável com alteridade institucional ou com humanização que se caracterize, tam- 
bém, por abertura ao caráter íntegro da pessoal-singularidade, por complexo que seja este caráter.

Quanto à geração de "gratuidade", cumpre elucidar que é a inauditamente humanizadora vivência dessa geração que faculta aprofundar e adensar a dialeticidade do pensamento. Já este pensamento é aquele que se apercebe de que seu próprio mover-se não é acessível à lógica formal, pois é desse automovimento que resultam diferenças e identidades, as quais, ao serem apropriadas, possibilitam fundamentar formalidade lógica. Especificamente, torna-se imediato à dialeticidade e apenas mediato à logicidade acessar a coincidência entre trabalho e sua própria divisão na determinabilidade do ser social, em aditamento à interpretação deste ser apresentada por Lessa (2007, p. 139-146) que o recolhe em Marx e Lukács. Por isso, ao longo do texto, a categoria trabalho há de acabar ultrapassada por inequivocação e desequivocação quanto a produzir, junto ao educando e ao educador, respectivamente.

Outros alertas talvez precisassem de imediata explicitação. Mas, cumpre considerar que os mais significativos sejam os dois acima apresentados; antes de tudo, em razão dos correspondentes significados humanizadores, ou seja, educativos. Ademais, a tarefa do leitor da (presente) investigação tenderá a ser menos árdua.

Já a estruturação do sumário deixa manifesto que a elaboração do texto segue os cinco momentos do método em pedagogia histórico-crítica: prática social, problematização, instrumentalização, catarse e síntese. Neste momento final, entra em pauta o significado da proposta educacional, na perspectiva de este significado ser entendido como antisseletivo ou em peculiares e quiçá possíveis horizontes da pedagogia histórico-crítica. 
A prática social (I), adjetivada como sócio-seletivista, é assumida com seu teor sincrético, porque já emerge condicionada a ocorrer exposta a ter de considerar também a pessoa do universitário, apesar de inexistirem graus de liberdade e perspectiva de sustentação coletiva para a docência ir ao encontro desta consideração. Beira já um impasse atentar para veraz qualidade e precisa cientificidade da educação universitária a ser promovida.

A problematização (II) é encaminhada, antes de tudo o mais, à conta de heteronomia e na superveniência de imprecisão sobre o que seja interpretável por qualidade educacional, ainda que existência de qualidade seja indispensável à inserção político-institucional no (pseudo)-sistema de ensino superior brasileiro. A relação, entre qualidade e cientificidade, também adentra insanável polissemia, de modo que houve de nascer, a partir do âmago da sócio-subjetivada, informalizada e marginalizada competência pedagógica, a necessidade ou problema de a qualidade ser hipotetizada às costas das pertinentes ideologias.

A instrumentalização (III), graças a amplo contexto de objetos de pesquisa disponibilizados por mestres-pesquisadores da FE/UNICAMP, contou com revisitação das circunstâncias em que emergiu a (então) nova paideia clássico-antiga ${ }^{14}$, com a tendência de o recurso à dialética se acentuar na instrumentalização de pesquisas mais recentemente empreendidas no campo de atuação humana da pedagogia ${ }^{15}$, bem assim com o caráter inusitadamente situado do sentido histórico-crítico

14 NUNES, 1999a; 2003a; 2003b; 2006. NUNES; GAMBOA, 1998.

15 GAMBOA, 1997; 2003; 2007. WACHOW ICZ, 2001. ALMEIDA; OLIVEIRA; ARNONI, 2007. MANACORDA, 2006. 
das ideias pedagógicas ${ }^{16}$. A partir destes últimos e incomuns marcos de produção acadêmica, tornou-se possível ao menos uma tentativa de propor especificidade dialética para se ir ao encontro de concepção, ainda que hipoteticamente também dialética, da educação universitária a ser promovida, partindo do real-concreto da socratiana dinâmica do desejo, passando pela proposta marxiana de desapossamento das fontes dos meios de vida e chegando à síntese do que faculta conceber caráter íntegro da pessoal-singularidade. Reflexivamente, a instrumentalização presume a si mesma, assim como os outros quatro momentos do método em pedagogia histórico-crítica, presunção que, até certo ponto, foi seguida, conforme algumas subunidades da pertinente abordagem: (a) absurdidade em construção (prática sócio-seletivista); (b) perspectiva de "historização" em crise e seus dois horizontes mais visíveis, assim como questões alternativamente acatáveis (necessidadeproblema); (c) forma, por entre opostos, do real-concreto da dinâmica do desejo, em contraponto à forma mediativoconfigurativa por entre os sentidos das necessidades e das funções que as atendem (especificidade dialética); (d) avanço coerente com a história da dialética (discernimento da forma); e (e) categorias fenomenicamente compreensivas do que está escondido sob o que está manifesto (concurso do método filosófico).

A catarse (IV) vem a ser o autodesvelamento da competência pedagógica, esta a se "historicizar" graças ao caráter inarredavelmente opcional da práxis coletiva a incidir no fulcro da autoafirmação da própria pedagogia. Por sua vez, esta autoafirmação passa a mediar, em intensidades diversas, as atividades docentes também externamente ao próprio e

16 SAVIANI, 2004; 2005; 2006; 2007b; 2007c. MELLO, 1998. NOSELLA, 2005. GASPARIN, 2007. LOMBARDI; SAVIANI; SANFELICE (Orgs), 2005. 
específico campo de atuação, abrindo perspectivas não apenas de (auto)-descolonização deste campo, como também de que ancoragem em desequivocação quanto a produzir serviços educativos carece de ser a fonte da pertinente cientificidade. Neste sentido, é essencial a divisão entre imaturidade ainda autoinsustentável e maturidade que sustenta a si mesma e, também, essa mesma imaturidade. Trata-se de divisão antitética àquela "historizada" no âmbito do trabalho e, tal como esta, cinde o real-concreto das relações sociais desde o coletivo natural-mínimo até a sociedade global. Esconder essa cisão incide na dualidade do que fundamenta o que é oculto e o que é manifesto no próprio método em fenomenologia, o que teria como explicar, sem que o justifique, alheamento fenomenológico à dialeticidade do produzir intelectual, assim como ao imaturo e culturalmente inercializado sobre-estar epistêmico da autoinsustentabilidade adulta. É que a sustentação deste sobre-estar significa subtrair os meios de sustentação da coletividade que é sintetizada pela própria imaturidade humano-natural. Se tal antítese à divisão do trabalho não incidir em ciência, então, há de responder, pelas (in)justificações em geral, nada mais do que a síntese entre anticiência e a própria ciência - o sentido natural-divino ou divino-natural da liberdade, enquanto valor intangível.

Na síntese $(\mathrm{V})$, à qual se chega a partir das iniciais e sincréticas percepções da educação universitária, é caracterizada a mediação competentemente pedagógica entre autoconhecimento e heteroconhecimento. Autoconhecimento coincide com a ciência de que, absurdamente, pessoas têm precisado pagar a outras para que as façam produzir de modo inequívoco, enquanto este fazer-produzir incide em trabalho improdutivo, cuja fonte tem sido remunerada por força de já e ainda estar viva, pura e simplesmente. Ademais, esta remuneração é usurpante daquela que é imprescindível à 
imaturidade ainda naturalmente autoinsustentável e à (re)produção das condições nas quais precisa desenvolver-se a maturidade cultural ainda a ser atingida. Admite-se um tácito e espontâneo posicionamento, pelo qual sempre se fez valer a omissão de educadores, ao preterirem evocação do inato potencial do educando para gerar gratuidade. Tal posicionamento já emerge político e antiético, porém, desde tempos imemoriais, tem sido irreconhecível, inclusive pela própria conveniência em ignorá-lo. Já esta conveniência perfaz ponto cego da (in)-justificação das instituições vigentes, cujo sistema tem precisado de autorreprodução e, com esta, do processo educativo. Cabe à competência pedagógica fazer minguar "metafisicidade" (descontinuidade de antemão criada) por entre política e ética, até que junção de ambas incida em alteridade institucional que proteja a inescapável fragilidade da autoafirmação propositivo-pedagógica.

A educação universitária a ser local-regionalmente promovida (VI) coincide com a definição do marco inicial de um processo de inarredáveis mudanças. Por sua vez, estas mudanças hão de responder à reciprocidade de coerência entre as hipóteses que explicitam esse mesmo marco. Neste sentido é que tão só a práxis coletiva, ainda que frágil e exposta a drásticos e incontáveis riscos, constitui real-concreto a se ter em conta. Cabe, então, auscultá-la, inclusive porque indisponibilidade, até mesmo de vias procedimentais a tanto imprescindíveis, não é explicação e, menos ainda, justificativa da condição hermética da explicitação formal-mediativa dos resultados da investigação obtidos até este momento. [Neste peculiar aspecto, talvez sirva de consolo remontar a Gramsci (1975), citado por Nosella (2005, p. 232), que "defende frequentemente a necessidade de se produzir e se ler textos difíceis, quando o assunto é complexo, rejeitando textos panfletários e dissimuladores"]. 
Nas considerações finais, urge aquilatar que qualidade educacional perfaz patrimônio de "agências-propriedade" da proliferação de pertinentes ideologias. Isto, talvez, concorra para se insistir na defesa das ideologias na esfera do discurso sobre educação. Todavia, reciprocidade de coerência e de pertinência quanto à diferenciabilidade do processo educativo faculta a gestores deste processo admitir que essa qualidade ultrapasse vezo ideológico por condicionar critério de cientificidade. Ritos de passagem, ao menos estes, em produção inequívoca hão de adentrar o sincrético miolo do exercício de liberdades que tem impedido tal ultrapassagem.

Antes de iniciar a leitura da proposta educacional adiante apresentada, urge assumir dizeres de Cunha (1978) que os explicitou ainda nos anos de 1970. São palavras que traduzem a saga desse emérito estudioso dos pretensos vínculos entre (a até então havida) educação e desenvolvimento social no Brasil.

Este livro é dedicado aos milhares de brasileiros que, generosamente, acreditam ser a educação escolar o caminho para a construção de uma sociedade aberta. Pensando assim e agindo conforme, eles rejeitam (implícita ou explicitamente) as condições de vida existentes. Mas, ao pretenderem transformá-las pela educação escolar, alimentam as ideologias que amparam e dissimulam as mesmas condições de vida que rejeitam. Reforçam, então, paradoxalmente, aquilo que desejam enfraquecer. Ao dedicarlhes este livro estamos reconhecendo a procedência das suas críticas, conscientes ou não, e manifestando nosso respeito pela motivação que os anima, 
embora nosso intuito seja o de chamar a atenção para as contradições possivelmente existentes entre suas práticas e suas intenções (CUNHA, 1978, p. 3. Grifos nossos).

Dentre as contradições em questão, embora ausente em ampla amostra dos textos do próprio autor, cumpre elucidar que a generosidade docente não tem evocado nem desenvolvido aquela dos alunos. Ao que tudo indica, usa-se a generosidade da juventude para que esta aprenda a se conduzir de forma estritamente interesseira.

Quanto às ideologias de educadores, as quais amparam e dissimulam o que eles próprios rejeitam, há de ser ainda elucidado que elas se apresentam com um vezo que lhes é comum, aquele de que é necessário apossar e desapossar as fontes dos meios de vida estritamente exteriores à pessoa, não importando o que, como e para que ou para quem. Já a pessoa mesma, ainda que egressa do processo educativo, jamais parece optar por desapossar-se, para que acabe por produzir o que é imprescindível à posse de quem justamente precisa desapossá-la, sob pena de a espécie e, com esta, tudo o mais não fazerem sentido. Assim, as pessoas estão todas demais e, ao mesmo tempo e lugar, absolutamente escassas. No primeiro caso, é porque não haveria como escapar à sina de competir até mesmo por espaço vital, o que se tornou inalcançável sem educação. Na segunda circunstância, haveria, no mínimo, como explicar o que está a acontecer, se educação apontasse alteridade de conduta, mediante ao menos abertura ao sentido de gerar "gratuidade" para fundamentar o senso do coletivo. Se adultos, a começar por educadores, persistirem na denegação de tal abertura em "soma zero" com seu autofechamento no interesse, as novas 
gerações precisarão restar condenadas a internalizar o errado em vez de externalizar o certo.

Efetividade do contraditório entre intenção e prática coincidiria com o mero conservadorismo. O que cumpre, ousada e modestamente, é enxergar ao menos fissuras na realidade, para ultrapassar a omissão adiante problematizada e chegar a autoconvencimento a respeito da proposta educacional a seguir exposta à crítica e a eventual validação. É óbvio que seria preferível menor esforço do leitor, conquanto, deixar de ser omisso não baste para prevenir, total e necessariamente, as limitações quanto à arte de comunicar. 


\section{Prática sócio-seletivista de uma educação universitária}

\section{A. Contextualização histórica junto à exclusão continental e nacional}

Por sua precoce presença no continente das Américas Central e do Sul, ou mais precisamente na América de colonização espanhola, a educação universitária constitui motivo para uma reflexão que encaminha para determinado questionamento: por que, mesmo após a independência política e subsequente marginalização de ambas essas Américas no contexto internacional, a erudição acadêmica não se deu conta de que sua inserção, inicialmente em contextos sócio-autóctones e ao final também em marginalização sociocontinental, deva fazer-lhe diferença e que esta diferença precise ser buscada, mediante competência em ao menos criticar o metropolismo de antanho enquanto residual e oculto na atual globalização?

Em sua análise sobre o alcance necessário da universidade na América Latina, Darcy Ribeiro manifesta sua percepção sobre tal questionamento.

Nas universidades latino-americanas, mantidas exclusivamente ou quase que exclusivamente pelo Estado, o problema da democratização do ensino superior ou da seletividade deve ser expresso claramente. Nelas há inversão 
de fundos públicos e apropriação individual deles por uma minoria. Que é que justifica esta apropriação? $\mathrm{Na}$ prática, apenas a explica o fato de que as famílias mais ricas, contando com recursos para subministrar melhor formação de segundo nível a seus filhos e para mantê-los enquanto disputam as vagas na universidade, os habilitam a apropriar-se das inversões públicas representadas pelo custo de formação de cada egresso. Aos privilégios existentes se soma, desta maneira, o de acumular novas regalias para aqueles que já gozam de muitas vantagens (RIBEIRO, 1969, p. 138).

Como já assinalou Aristóteles a respeito do comunismo em Platão, este esquecera a necessidade de igualar os desejos ou, após o moderno Habermas (1982), os interesses. Dado que desejo ou interesse tem sido inescapável mediação do proceder fragmentador dos reais-concretos, ou seja, dos próprios objetos expostos à escolha de pesquisadores, a proposta da universidade necessária de Ribeiro para a América Latina não passou do "problema da universidade". Ademais, ao propor uma tal universidade, o próprio Ribeiro (1969, p. 167-212) projeta-a como alternativa ao modelo que ele considerou utópico:

[...] contam com maiores possibilidades de autossuperação e de desenvolvimento e que se propõem serem centros dinamizadores da criatividade cultural de uma nação ou de uma região determinada (devendo, para tanto, dentre outras funções) opor aos projetos de 
colonização cultural da América Latina e de perpetuação de seu subdesenvolvimento e dependência através da modernização reflexa, um projeto próprio que preencha, no âmbito universitário, os requisitos fundamentais de desenvolvimento autônomo da nação (RIBEIRO, 1969, p. 171- 172. Nossos os termos entre parênteses).

Cabe questionar Ribeiro se "criatividade cultural" e "âmbito universitário" teriam como não mais permanecer, sociogeograficamente, fenômenos privilegiados. Assim, em contraponto a Ribeiro, aventar-se-ia que tal criatividade seja necessária para que o âmbito universitário tenha por referência, nele mesmo, substrato humano real-concretamente comum ou universalmente mediativo-dialético, partindo-se, neste sentido, dos posicionamentos de Sócrates, Platão e Aristóteles a respeito da dinâmica do desejo, e tendo em conta o alcance, há pouco planetário, do abalo provocado pela iniciativa marxiana de subtrair, aos eternos vitoriosos, as propriedades das fontes dos meios de vida e, com isto, fazer com que também tais vitoriosos enxerguem o modo de existir vazio, imaterial ou não sensorial dos objetos de desejo irrealizado ou irrealizável, objetos que correspondem a ilimitações dos seus patrimônios e a carências dos despossuídos daquelas fontes. Além disso, urge que tais vitoriosos descubram que esse modo de existir tem sido criado por eles próprios e que implicaria em todos o padecerem, em vez de tão somente os derrotados. Assim, humanização teria que intervir, antes e propriamente, nos teores de ensino e a partir das entranhas da universidade, além de que apenas tal intervenção possibilitaria chegar ao sentido da autenticidade universitária, em vez de a este ou àquele modelo situadamente sociogeográfico. 
De toda forma, urge reconhecer que Ribeiro (208-211) ao menos tentou desmarginalizar o processo educativo em seu modelo de universidade para a América Latina, ao propor um "status" institucional mais condizente para as faculdades de educação. Todavia, inclusive em sua originalidade, essas faculdades continuam só tendo a ver com o que fique abaixo de um tal "status", pois, acima, a superioridade cultural se traduz na hegemonia de definidores de oculta "educação das educações” a colonizar o campo da atuação pedagógica.

De toda forma, tem havido ao menos uma promessa de força autentificadora da universidade latino-americana, aquela da participação dos estudantes nas recorrentes tentativas de mudar os rumos da educação que se pretende superior. A propósito e segundo Cunha (1983, p. 209-210), já (e apenas) em 1908, em Montevidéu, realizou-se o "1º Congresso dos Estudantes Latino-Americanos", seguido da iniciativa do governo uruguaio de instituir representação estudantil na universidade. Esse Congresso voltou a ser realizado em Buenos Aires em 1910 e, a seguir, em Lima em 1916. Mas, um marco histórico da mobilização estudantil deu-se, no nível nacional, em Córdoba, Argentina, do qual resultou a "Carta de Córdoba". Neste registro histórico de 1918, acabou formulada uma série de reivindicações para uma reforma da universidade naquele País, "contra um regime administrativo, contra um método docente, contra um conceito de autoridade", os quais vinham caracterizando a universidade oligárquica e clerical. Apesar da trilha reformista dessa Carta, o desfecho emergiu pouco ou nada significativo.

[...] coloca-se predominantemente em termos de uma universidade aberta, porém, de uma abertura que trazia implícito seu sentido classista, pois aqueles que podiam chegar aos estudos 
superiores não eram precisamente os operários nem os camponeses. Abrir a universidade ao povo se converte no lema favorito da pequena burguesia e classe média intelectualizada; o signo desta "abertura" teve distintas expressões segundo as épocas: departamentos de extensão universitária, aumento de bolsas, eliminação dos exames de ingresso, incremento das verbas, mais tarde, campanhas de conscientização (CUNHA, 1983, P. 210-211).

Assinalem-se, nessa citação, objetos de desejo e/ou de interesse, cujo estudo carece de recurso à "maiêutica socrática”, para tanto atualizada como desequivocação entre desejo e vontade ético-política, assim como ao "desapossamento marxiano" como inversão, em âmbito objetivamente prático, entre tese e antítese. Ambos - desapossamento e desequivocação - têm como constituírem motivos de conflito na esfera também da subjetividade, ou seja, em alteridade de via ao longo da qual cumpre tratar dialeticamente desde a presença dos tentáculos da velha metrópole ibérica com a elite sua preposta, seguida pela elite politicamente autônoma e (re)produtiva desses tentáculos.

Todavia, em se tratando de jovens ainda em fase culturalmente prolongada da natural-finita autoinsustentabilidade, suas reivindicações não emergem de todo descabidas. Mas, na esfera de adultos, a não vacilarem em propor rumos críticos para a universidade, cumpriria ultrapassar um mero "estar contra" aquela (re)-produção, conforme o discurso da universidade a se modernizar preferencialmente em avanço científico-técnico, seja este autônomo ou nacionalista, seja integrado ou internacionalista. Trata-se de avanço que ainda 
hoje está sendo projetado, de forma alheia até mesmo ao que Chauí (1999a, p. 215) aponta como "democracia fundada na noção de direitos, e por isso mesmo está apta a diferenciá-los de privilégios e carências", pois os privilégios “são, por definição, particulares, não podendo generalizar-se num interesse comum nem universalizar-se num direito".

Em desfecho, a presença da universidade no bojo da marginalização - esta, desde a abrangência continental, passando pela nacional e chegando à local - ainda não incidiu na diferença de existir devotada ao que seja generalizável somente a partir do "miolo" da realidade, uma vez que seus prepostos e partícipes continuam alheios ao princípio de que deveres precedem direitos e à noção de que cidadania há de implicar, sempre e antes de tudo, em dar conta de certas rubricas da mais-valia, cujas análises acabaram adiadas "ad aeternum” por Marx (1984, p. 246), nem foram visualizadas por seus intérpretes e continuadores, ainda que "frankfurtianamente" teórico-críticos. Cabe, então, indagar: até quando especialistas, mestres e doutores - peculiarmente se de esquerda, progressistas e, inclusive, críticos - persistirão em silenciar nos interstícios de suas falas e nas entrelinhas de seus textos que tributo também é lucro e que a pertinente inserção no processo produtivo (hoje nos monetizados preços dos meios de trabalho) vem a ser a mais decisiva causa da exclusão social? Por que precisa ser mais fácil dar a volta ao cosmos do que dar conta do entendimento de que a equivalência de paga por tudo o que se faça tem coincidido, em primeira e última instância, com o próprio fenômeno da tributação? Por que se tornou imprescindível que o Estado estimule lucro privado para aumentar o próprio? Por acaso o que é sustentado por tributos teria como ser inequivocamente público? Por que, afinal, essas informações têm tido que ser sonegadas aos jovens, já enquanto ambiência em que 
crescem, tornando-os precoces cúmplices da adultez teimosamente imatura?

No Brasil, a educação superior, exceto Medicina e Direito, só teve início já avançada a primeira metade do século XX. Pouco depois desta deflagração, começou a ser sacudida pela apropriação de (importadas) categorias marxistas, cuja influência veio a colocar em campos opostos, não apenas os então dominantes alcances laico-público e católico-confessional da universidade, como também conservadorismo e revolucionarismo no âmago da própria concepção da academia laico-pública ${ }^{1}$.

$\mathrm{Na}$ atualidade, há uma marcante diferença nos discursos educacionais em que se opõem, entre si, as instituições mantidas pelo poder público e as demais de direito civil. As primeiras, por mais que se insista em não o admitir em defesa contra o cerco neoliberal, gozam de uma socialmente cotada qualidade acadêmica, da qual há como se valer, mediante apelo a um discurso de sua "excelência", em busca de excludente prioridade no acesso a recursos (ditos) públicos e de autonomia nas atividades acadêmicas. Já as instituições privadas, estas se encontram em situação assimétrica. Por mais que nelas ocorresse ou mesmo se buscasse até mesmo uma autenticidade de conceituação de qualidade, todo o empenho, neste sentido, estaria de antemão frustrado. Restar-lhes-ia apelar para as ciências de vender e para a inciência de comprar

1 Em termos filosóficos (ABBAGNANO: 2007, p. 691-3), existir escola só pública ou só irreligiosa contradiz laicismo, pois, se este incidisse em excludência, acabaria contraditório nos próprios termos. Assim, cumpre ao menos hipotetizar que a influência revolucionarista nos labirintos da apropriação de (importadas) categorias marxistas tem a ver com oposição entre, de uma parte, desejos irrealizados e/ou irrealizáveis de despossuídos de poder, e de outra, interesses enquanto desejos realizados e realizáveis de egressos de um ensino superior a dinamizar e consolidar seletividade. 
serviços educativos, a par de padecerem uma heteronomia em cujo âmbito acabam largamente imprecisos, entre si, o cumprimento de leis e um usurpar poder legislante junto à burocracia oficial. Em notório contraponto a essa assimetria, a participação estudantil, nos órgãos colegiados, tende a permanecer meramente ouvinte e aparentemente atônita. Representa participação estudantil alienadamente politizada.

A partir dessa síntese, mesmo que expressa de forma excessivamente densa, emerge uma inevitável indagação: na vigente realidade educacional brasileira, não se estaria a realimentar a tentação da conquista de privilégios? Trata-se de indagação que já transparecia na crítica de Cunha (1989, p. 59-61) contra "Os equívocos dos remendos" ao modelo universitário de 1968, ano da maior, mais memorável e, sobremaneira, mais inconsequente revolta estudantil até na velha Europa. Entretanto, nem esse notório estudioso da educação superior, no Brasil, atenta para a circunstância de que a conceituação de qualidade vem a ser a raiz da problemática da educação universitária e que, por isso mesmo, é condição para se buscar mudança a montante (educação pré-universitária) e a jusante (pós-graduação).

Segundo Demo (1978; 1987; 1985), qualidade há de compreender política (participar), assim como cultura (perfazer formalidade), além de não ser facilmente enxergada. Por isso, talvez, qualidade esteja a ser reduzida a estrita cotação social do ensino nos três principais níveis do processo educativo (pré-universitário, universitário e pós-graduação). Em todos esses níveis, tem respondido à abundância ou escassez de meios objetivo-exteriores à pessoa do estudante e tem coincidido com o abandono, à própria sorte, da subjetivointerioridade do educando com suas potencialidades. Em 
rigor, estas potencialidades têm de acabar marginalizadas, informalizadas e sócio-subjetivadas, em favor de nada mais do que aquisições provindas do seu exterior.

Na perspectiva de menor cotação social, há o nível de ensino pré-universitário público que vem sendo socialmente menos cotado que o seu equivalente particular, à conta de depender de um federativamente desestruturado setor público que, por isso, não tem atribuído suficiente prioridade a esse nível de ensino. Contrariamente, o ensino universitário (dito) público tem tido maior cotação social pela circunstância de sancionar a seletividade processada no nível inferior, o que deriva do enredamento de três facilitadores: (a) oferta firme sem paga direta pelo estudante; (b) rigorosidade nos exames vestibulares; e, (c) discurso da excelência ou da hegemonia da "qualidade das qualidades".

A propósito da resposta à abundância ou à escassez de meios objetivo-externos ao educando, tem sido menor a cotação social do ensino no nível pré-universitário público, uma vez que se encontra inserido em carências diversas, a começar pela insuficiência, inclusive crônica, de renda domiciliar, com suas conexas mazelas de desnutrição, precariedade da habitação e adjacências desta, a par do abandono da criança e do jovem à própria sorte, por ser impossível considerar a pessoa de cada um e de todos. Já a cotação social da escola particular é maior, porque tais carências estão menos presentes, ou mesmo inexistam, e o estudante, uma vez amparado por seus responsáveis ao longo da própria e natural autoinsustentabilidade, tem tido como desenvolver uma "menos pior" aprendizagem nas devidas idade e intensidade em prol de defensiva autosseletividade.

No âmbito do ensino superior, a relação entre a subjetivo-interioridade do aluno e a objetivo-exterioridade dos 
meios precisa ser cotejada com uma mais difusa concepção de aprendizagem para que se entenda a maior cotação do ensino superior (dito) público. É que essa concepção está a ter, por seu fulcro, assimilação de narrativas de saberes (tidas por conhecimentos), bastando que esta assimilação seja aquilatada em posições mais elevadas de escalares "olímpicos" de notas obtidas em testes verificativos. Trata-se de assimilação que presume plena disponibilidade pessoal para assistir aulas e desenvolver atividades correlatas. Nesta circunstância, autossustentação do estudante se torna problemática, porque sua natural-finita dependência acaba indevidamente prolongada, além de restar favorecida, para não dizer incentivada, indiferenciação entre apropriar e produzir.

Assim, qualidade educacional presumiria mais aprofundado reconhecimento das implicações coletivo-sustentatórias dessa concepção de aprendizagem, prevenindo-se necessidade de ideologizar relações sociais e de acabar, até mesmo conveniente, a marxiana involuntariedade de inserção nestas mesmas relações. E, por força desta inserção, ideologiza-se qualidade à base de escores preferencialmente mais aproximados do ápice do referido escalar "olímpico" e em correlação com disponibilidade de meios objetivo-exteriores ao estudante, peculiarmente titulação dos docentes e infraestrutura.

As instituições privadas, na atualidade majoritariamente receptoras de estudantes, têm tido que imitar os procedimentos das públicas, sob pena de os prepostos da burocracia estatal asfixiá-las com controles que, além de veraz-qualificativamente inúteis, intentam que suas vítimas lhes apontem o que ignoram, ou seja, sentido veraz de qualidade e preciso de cientificidade sobre o que seja aprendizagem em resposta a ensino.

Sintoma de que a referida cotação social esteja a ser ideologizada como qualidade do ensino superior reside em que 
a determinação constitucional (Art. 205) do "pleno desenvolvimento da pessoa" do estudante está a ser preterida, por subsunção a abstrações veiculadas por códigos e correspondentes escalares de assimilação de narrativas de saberes. Reforça-se tal sintoma, por exclusão do oposto, pois resta de antemão inviável aquele desenvolvimento vir a ser considerado. Para tanto, não há disponibilidade de métodos, nem de imprescindíveis recursos humanos e, inclusive, de meios infraestruturais.

Em síntese, a condição superior do ensino teria que passar pelo crivo de questionamento da sua qualidade. Afinal, custaria não suspeitar de que, estando assim desvinculada de humanização e de relações interpessoais, à conta do alcance abstrato de códigos e escores avaliativos, superioridade de ensino estaria a servir de "álibi" para que este mesmo alcance abstrato compense a própria desvinculação.

Resta, ao menos, problemático que seja veraz "a” qualidade que povoa o discurso sobre o alcance superior da educação no Brasil. E, se de fato não for veraz, o quê a mudará?

Em resposta a esta pergunta e, por ainda hipotético que o tenha que permanecer, cumpre ter em vista que educar perfaz mediação, o que também acontece com a dialeticidade da própria desequivocação quanto a produzir serviços educativos, junto a educadores antes de tudo. Por isso, admite-se formular, ao menos em hipótese, que a associação de ambas essas mediações potencialize cientificidade e determinabilidade da qualificação educacional propriamente universitária. Eis o que cumpre considerar, a seguir, partindo-se de determinada inserção do ensino superior em uma realidade local. 


\section{B. Situação local-regionalmente interiorizada}

Antes que estivesse sequer cogitada a instalação da IES em causa no Oeste Baiano e em Barreiras, precedeu-lhe uma diagnose a respeito do impasse da sustentação real do intencionado desenvolvimento socioeconômico do Brasil ao longo das décadas que sucederam as mudanças decorrentes da depressão mundial ocorrida em 1929. Esse impasse acabou confrontado com a residual alternativa de se apelar para poupanças financeiristas internas e/ou externas, alternativa que acabou por prevalecer, uma vez que saída oportuna e propriamente real acabou preterida ao longo dos anos 40 e 50 do século recém-findo.

A diagnose apontava para omissões que persistiam nos bastidores políticos em que triunfou o "Plano de Metas", implantado a partir de 1956, tendo por eixo locacionaldesenvolvimentista a transferência da Capital Federal para Brasília.

Nos mencionados bastidores, poderiam ter sido apontados dois fenômenos a serem, à época e regional-politicamente, aquilatados nas perspectivas de "saída mineira" x "omissão baiana" 2 . A primeira, vitoriosa nas eleições de 1955, representou notórios desdobramentos em termos de lançamento de infraestrutura de energia e transportes, assim como um nada surpreendente descaso em termos político-educacionais. Quanto a este descaso, não era considerado, à época, o aprofundamento do já inegável desencontro entre, de uma parte, ensino - peculiarmente, enquanto acesso a

2 A respeito desta (devida e alternativa) aquilatação, chegou a circular entre amigos um texto mimeografado sobre a pertinente problemática, conforme BERGAMO, P. Atalhos para a equidade. Brasília: SEDAEX, 1997. (mimeo). 
especificidades científico-tecnológicas - e, de outra, desenvolvimento socioeconômico regional-nacional. Presumia-se, político-inercialmente, que fosse possível dar continuidade ao velho modelo de exploração e apropriação metropolista de resultados do trabalho de fonte humana sem tal ensino, bem como de gratuitas contribuições de recursos naturais (fertilidade natural do solo, depósitos minerais e flora, basicamente) em novas fronteiras, sobretudo na Amazônia e a começar por aqueles disponíveis ao longo do eixo Belém-Brasília³

Entretanto, a principal questão social dos tempos então em curso derivava do desequilíbrio entre população e produção, estando praticamente ainda restrita ao Nordeste, de onde sucessivas levas de migrantes, sem perspectivas de retorno, aportavam no Sudeste e, a seguir, seriam desviadas, ao menos parcialmente para o Centro-Oeste, na esteira das influências decorrentes da construção da nova Capital.

Era, então, gritantemente óbvio que aquele ensino precisasse ser priorizado no Nordeste, emblematicamente no Estado da Bahia, onde (ainda hoje, 2008) ocorre o mais expressivo bolsão de pobreza rural. Este Estado também é aquele de maior contingente de eleitores da Região Nordeste, sendo possível à sua representação política liderar regionalmente as demais.

3 À época (entre 1946 e 1962), segundo Saviani (2007b, p. 277-302), eram objeto de discussões os teores da Primeira Lei de Diretrizes e Bases da Educação (Lei n. 4.024, de 20.09.1962), elaborada para dar conta da "competência da União para legislar sobre diretrizes e bases da educação nacional" (artigo $5^{\circ}$, inciso XV, alínea d, da Constituição de 1946). As preocupações então vigentes estavam relacionadas com as disputas ideológicas entre a corrente laica (estatal) e a corrente religiosa (católica) da questão educacional, a par do predomínio da pedagogia da Escola Nova com seu viés seletivo ou elitista. 
Por que, afinal, priorização do processo educativo no Nordeste não foi atendida, junto aos prepostos do Poder Público e nas pertinentes esferas? Resposta a esta indagação deveria incidir no esgotamento do secular modelo de exploração da gratuidade da natureza livre e da fonte humana de trabalho. A continuar tal modelo, seriam implantadas capitais de novos estados, reproduzindo-se, no eixo Brasília-Nordeste, o que sucedera com os artifícios urbanos de Belo Horizonte e Goiânia. De fato, o artifício veio a acontecer com a implantação de Palmas no novo Estado de Tocantins. E também viria a ocorrer com a (tacitamente possível) implantação de uma capital para o futuro Estado do São Francisco (extremo oeste da Bahia). Logo a seguir, esgotou-se de vez o modelo em questão.

A ocupação do extremo oeste da Bahia teve sua remota origem nos mais isolados e distantes sertões da antiga Capitania Hereditária de Pernambuco. Ao longo dos séculos XVI a XVIII, para lá se deslocavam foragidos do regime escravagista, assim como criadores de gado, na antiga tradição extensiva da "Casa da Torre". Estes últimos se expandiram, conforme Rocha $(1983,26-7)$, a partir da atual cidade de Barra (antiga São Francisco de Chagas da Barra do Rio Grande). Na virada do Século XVIII para o XIX, migrantes procedentes de Barra subiram o Rio Grande até onde era possível navegá-lo (as barreiras), onde passaram a produzir alimentos para suprir populações exploradoras de depósitos minerais e de pedras preciosas, destacando-se a garimpagem de diamantes na Chapada Diamantina.

Esses migrantes acabaram por implantar, a pouca distância antes das referidas barreiras, um avançado e pioneiro entreposto de comércio entre Nordeste e Brasil Central ${ }^{4}$, cuja

4 Conforme: ALMEIDA, I. P. Barreiras: uma história de sucesso. Barreiras, BA: CANGRAF, 2005, 4;15;24. 
história faz lembrar uma temporã "feitoria" lusitana. Junto a esse entreposto surgiu o povoado, depois a vila e finalmente a cidade de (São João das) Barreiras. Foi a partir desse entreposto que, gradativamente, Barreiras veio a se tornar polo de outros núcleos urbanos regionais, vindo a criar e concentrar uma cultura que, por sua vez, é traduzida por uma peculiar busca de romper com o isolamento dos migrantes, cuja origem os caracterizou como ribeirinhos, denominação já atribuída aos residentes ao longo da calha do médio Rio São Francisco e do Rio Grande. Um traço marcante, talvez o mais representativo dessa busca, sempre se manifestou por uma interiorana e silenciosa epopeia, tecida de persistência, ousadia e suor, em prol de soluções para romper com o seu isolamento sociogeográfico. Essa epopeia deixou seus vestígios nas relações sócio-locais de produção, vestígios que se caracterizam, de uma parte, por englobarem esforço produtivo e mercado local e, por outra parte, por desenvolverem intercâmbio orgânico com a natureza, sob notório risco de não acabarem compensados, peculiarmente no devotamento de meeiros à pecuária extensiva e à navegação fluvial (ROCHA, 1983, p. 32-34) ${ }^{5}$. A necessidade de produzir e intercambiar determinou o atributo de "produtivos" até aos grandes proprietários ("coronéis") por ali instalados. Estes proprietários não costumavam cercar suas propriedades, mantendo-as peculiarmente abertas à cooperação de despossuídos.

5 Esta referência continha uma proposta de redirecionamento da contemporânea indústria têxtil, tendo por matéria-prima algodão, a ser produzido em plantações também irrigadas, bem como de obras públicas voltadas para a regularização do Rio São Francisco. Ainda que o autor contasse com meio próprio de divulgação na Capital da República e com apoio de banqueiros internacionais, sua proposta, de surpreendente sentido integrador do território nacional, não mereceu atenção dos políticos contemporâneos, inclusive nordestinos. 
Ao se iniciar o "ciclo da borracha", a coleta de látex de mangabeiras acarretou notório impulso à vila de Barreiras, na qual também veio a surgir um surpreendente surto industrial entre as décadas de 1920 e de 1960, a par da implantação de um aeroporto (financiada pelos EUA), para embarcar alimentos nas aeronaves que se deslocavam para o "front" na Europa. Porém, logo ao início do regime militar, os barreirenses vieram a sofrer o maior dos golpes nas suas conquistas contra seu originário isolamento, pois foram desativadas as barcas de navegação fluvial, assim como a usina hidroelétrica e o aeroporto internacional.

Desde essa época, acentuaram-se na cultura local-regional os impactos de um (até precoce) processo de globalização, inicialmente de cunho religioso procedente do Sul dos EUA e, a seguir, com a chegada de um batalhão rodoviário do Exército, o qual se instalou em vila própria, ameaçando deflagrar, localmente, o contraste entre o "novo" e o "velho", conforme categorias utilizadas pelo geógrafo-humano Milton Santos. Com a abertura de estradas, interligando Barreiras com Salvador (BR 242) e com Brasília (BR 020), o comércio e a prestação de outros serviços urbanos passaram a se expandir, enquanto aqueles resíduos de cultura autóctone vieram a se defrontar com uma espécie de crise. Por outra parte, a predominante influência de Salvador veio a ser contrabalançada pela acentuada polarização ao eixo Brasília-Goiânia e ao "enxerto" regional de aspectos culturais ditos "sulistas", sobremaneira após a criação do Município de Luís Eduardo Magalhães, a $92 \mathrm{~km}$ a oeste de Barreiras e na rota migratória para o Centro-Oeste.

A presente situação sociogeográfica de Barreiras e do Oeste Baiano responde a dois supervenientes e cumulativos impulsos de abertura, os quais atropelam, ou ao menos 
ameaçam, o sentido da busca, até então prevalecente, de ultrapassar o referido isolamento e, com isto, passam a determinar questões de desenvolvimento humano de significado pouco ou nada perceptível aos olhares habituais: (a) impulso produtivo-tecnicista: avanço, ainda em realimentação, da fronteira agrícola do Centro-Oeste até os cerrados baianos, em cujo apoio local-regional, o comércio e a infraestrutura de serviços urbanos, por insatisfatórios que ainda hoje se os julguem, foram os poucos disponíveis até a recente emancipação do referido Município de Luís Eduardo Magalhães; e, (b) impulso educacional, em plena ocorrência, devido à atuação de campos avançados de duas instituições públicas - Universidade Estadual da Bahia (UNEB) e Universidade Federal da Bahia (UFBA) - e à presença de cinco IES privadas, com destaque para a Faculdade São Francisco de Barreiras (FASB).

A inserção local-regional da educação superior precisaria ocorrer no sentido de remediar e prevenir, a partir das suas ambiências interna e externa, implicações injustificadas e injustificantes do impulso produtivo-tecnicista. É peculiarmente em tal sentido que cumpre ao menos intuir a presença local-regional de uma IES privada sem fins lucrativos, como tem sido o caso da FASB.

No caso de traços culturais, ainda cabe ter em conta que se reproduzem notórios resíduos da mencionada "cultura do isolamento", porém em circunstâncias sempre mais adversas às condições em que emergiram. Nos bastidores das estórias a comporem a cultura regional-local, a educação almejada nos tempos de isolamento era a oferecida em Salvador e chegava até o nível universitário ${ }^{6}$. Localmente, apresentou certo viés

6 Conforme: ROCHA, G. op. cit., p. 27 e ALMEIDA, I.P. op. cit., p. 25-26. 
voltado para a conquista de "status" social, excetuando-se os pioneiros esforços da UNEB em promover formação de professores.

Nas circunstâncias atuais desse contexto, educação tem prioridade extremamente díspar no nível das pessoas e criticamente precária, para não dizer que é nula, junto aos poderes local-regionalmente constituídos. Ainda é incipiente uma socializada percepção de significado para categorizar educação no plano sócio-representativo de "bem público" de "elevado valor científico e social" - conforme termos dos textos oficiais. Paralelamente, não é claramente percebido pela juventude local-regional, candidata ao ensino superior, o "guiso" metropolístico a impelir jovens por força de que "ruim com diploma, pior sem ele", cuja exploração vem permitindo que a mera "dação de aula" seja apregoada por sua "excelência” e seduza a juventude em seu já emblemático impasse (auto)-orientativo. De outra parte, à conta do alcance institucional dos propósitos avaliativos do macrossistema oficial (MEC e órgãos conexos), é difícil não admitir que atributos de qualidade do ensino superior, no Brasil, não estejam a (re)-produzir superioridade metropolista.

As circunstâncias impõem "propagar" serviços educacionais em bases radicalmente inovadas, deixando para trás certos desvios do modelo "dação-escuta" de aulas, voltado para acumular e reproduzir narrativas de saberes a título de conhecimentos. Tal ultrapassagem está a ser desafio da autoafirmação pedagógica na própria IES.

Nas ambiências interna e externa da IES, têm sido difusas e imperantes as restrições para a educação ser assumida como prioridade, precisando, para tanto, valer-se de fissuras, poros ou lacunas, nos quais logre desenvolver raízes. E é precisamente essa busca que perfaz o alcance propriamente 
"crítico-teórico" da relevância e do significado das condições em que a FASB projeta sua missão, além de fazer sua história e sua diferença. Os profissionais de educação nela atuantes têm precisado vivenciar tais circunstâncias, para se aperceberem do teor do desafio que é buscar veraz qualidade e precisa cientificidade da educação a ser promovida.

\section{Mediação pelo "paradigma da insustentabilidade coletiva"}

Constata-se uma situação em que há coincidência entre desafio gerencial da "impulsão para o ganho" (WEBER: 1983, p. 4) e hipótese de trabalho em pesquisa-ação, no âmbito de uma IES que se encontra inserida em uma sócio-ambiência interiorana. Nesta sócio-ambiência, as injustificações em geral, (desigualdades políticas, disparidades econômicas e desníveis de acesso à tecno-ciência) têm a ver com ônus impingido por tentáculos metropolísticos a incidirem sobre as atividades sustentatórias das vigentes relações sociais. É ônus que tende a ficar ampliado, por força de esses tentáculos se disseminarem em alcance local, regional, nacional, continental e global.

No "miolo" dessa IES, têm sido frequentes os conflitos entre professores e alunos, os quais recorrentemente ameaçam impedir uma periódica aquilatação político-institucional de como está a se processar a realidade da relação entre ensino e aprendizagem. Em busca de múltiplos determinantes de uma tal recorrência de conflitos, aventou-se embasar os requeridos procedimentos nos objetos de ciências positivoadministrativas correspondentes às análises de ambiências, simultaneamente externa e interna, assim como delimitar, mediante pesquisa-ação, o problema a ser enfrentado por 
ações de alcance pedagógico. Após sucessivas aproximações a respeito daqueles determinantes, a busca acabou por apontar uma problemática, pois, se a docência fosse agir na perspectiva de melhorar a ambiência educativa, a situação tenderia a uma crise institucional por força da imprecisão e pluralidade de interpretações a respeito do significado do próprio termo melhorar. Olhando-se obliquamente para a situação da docência, o fulcro de tal problemática residia na tendência a se incidir em total falta de graus de liberdade - envolvimento em uma espécie de "camisa de força" - para abraçar outra busca, aquela de veraz qualidade da educação a ser promovida e, na conjuntura, antídoto a uma intensificada ameaça de autoinsustentabilidade da própria IES (da ocupação de pessoas ou do próprio "ganha-pão" destas). Já a intensificação dessa ameaça é resposta ao discurso midiaticamente veiculado sobre qualidade educacional - esta, acentuadamente convertida em "signo-mercadoria", à conta de burocratizante intervenção das próprias autoridades educacionais que até deliberadamente se propõem a dinamizar competição entre instituições do sistema de ensino superior.

Dentre os principais determinantes daquela "camisa de força", quatro deles se desvelavam mais decisivos: (a) heteronomia político-institucionalmente hegemônica, a qual tem condicionado o processo educativo, desde o ensino fundamental e médio, até a pós-graduação, mas a assumir peculiar presença no caso de instituições isoladas de ensino superior privado; (b) anomia de estudantes, à medida que muitos destes têm persistido autoinadministráveis no âmbito de suas subjetividades, além de omissamente se deixarem representar por oportunistas que sequer enxergam a injustificação que soe acompanhar autoentrega a "arrogância reivindicalista" - esta a desvincular obrigações em relação a direitos, entre vítimas de irreflexa aquisição de fragmentadas e fragmentárias 
narrativas de saberes (tidas por) conhecimentos; c) superveniência de marco regulatório para as remunerações das atividades docentes, marco no qual a hora-aula se tornou excludente suporte processual para remunerações serem determinadas, além de favorecer a propensão a transformar aulas em oportunidades de exercício de micropoderes na relação entre fala docente e escuta discente; e, (d) a estressante condição sustentatória de uma IES de direito privado, em que nenhuma prioridade se faz valer, se a receita não for, pelo menos, igual à despesa.

Cumpre, todavia, aquilatar que esses determinantes sempre se encontram mediados por involuntariedade que caracteriza a inserção nas relações sociais, a começar por aquelas de produção e, inclusas nestas, as de produzir serviços educacionais. É que, em primeira e última instância, tal involuntariedade tem decorrido de as pessoas deterem necessidades cujo atendimento implica a imprescindibilidade de produzir, ainda que, para tanto, o presumido intercâmbio orgânico com a natureza esteja a contar com acentuada instrumentalização científico-tecnológica, cuja propriedade se tornou o fulcro do que carece ser contestado, uma vez que produzir, por impreciso que o seja, tem constituído excludente critério de acesso aos resultados de tal intercâmbio, assim como determinante de os seres humanos se sentirem de sobra, demais ou absurdos. Já à conta da detenção de necessidades, aquela involuntariedade abarca despossuídos e possuidores das fontes de meios de vida, fontes estas tanto externas quanto internas às próprias pessoas.

A mediação daquela involuntariedade sempre incidiu na condição de a dinâmica do desejo ou da interessença se transformar na necessidade culturalmente criada de as outras, as naturais-básicas, serem até mesmo antivaloradas, 
juntamente com quem precise ocupar-se com atendêlas, sem interpor outrem por entre este atendimento e os imprescindíveis meios.

Assim, a busca de veraz qualidade de uma educação a ser promovida passava a se expor ao risco de aqueles que a abraçassem se depararem em uma encruzilhada: exporem-se à (auto)-aquilatação de estar "bobo da corte", assim que se empenhassem em pesquisar e testar tal qualidade, ou então, que se entregassem à cômoda, para não dizer conveniente tese, de continuar sociofuncionais à (re)-produção das injustificações, uma vez que a única alternativa possível persistiria em um amálgama entre cruzar os braços e contribuir para o caos total em que a universalidade da revolução acabe bemsucedida, quiçá à base de materialismo histórico e dialético, e seja extirpado o vigente modo de produção.

Circunstancialmente, já estava a intervir nesse contexto a discussão das relações entre "paradigma da insustentabilidade coletiva" e sustentação da educação universitária, esta enquanto tema-chave em pedagogia. Em tal discussão, foi apontado o problema da falta de discernimento entre apropriar e produzir, assim como a hipótese de que inequivocação quanto a produzir serviços educativos se tornara já imprescindível.

À época, uma preocupação com ensino para a competência, mediante objetivos concebidos da perspectiva do educando e não do educador, insinuava que existisse qualidade de um processo educativo, desde que este fosse encaminhado com o apoio científico-tecnologicamente pedagógico de três indagações e em relação a um recorrente produzir, sobre cuja inequivocação mal e mal se ensaiavam os primeiros questionamentos. 
(...) (1) o que é necessário produzir como resultado das ações dos atuais aprendizes, quando estiverem "formados", (2) com que aspectos da realidade os aprendizes terão de lidar, quando estiverem "formados", para produzir esses resultados e (3) o que os aprendizes necessitarão estar aptos a fazer para lidar com esses aspectos da realidade de forma a produzirem resultados que sejam significativos para a própria vida e para os demais (KUBO; BOTOMÉ, 2001, p. 160-161. Grifos nossos).

Para pesquisar contexto de produção em que não fosse possível discernir entre vício e virtude e no qual inequivocação quanto a produzir sequer fosse admissível, evocou-se saída procedimental tirante à "maiêutica" socrática que, por sua vez, foi abordada à base da dialeticidade que é inerente à (também socrática) dinâmica do desejo, além de testada por implicação, nessa mesma dinâmica, das propostas de Platão e de Marx da despossessão de propriedades extrínsecas à pessoa. Assim, a investigação veio a apontar que o produzir inequívoco e ainda não forçosamente assumido - ainda tem tido como ocorrer na "relação entre prole e quem, direta ou indiretamente, a sustenta". Esta sustentação sempre se caracterizou como "posse do coletivo natural-mínimo" (condição de o indivíduo ainda autoinsustentável contar incondicionalmente com outrem para que sejam atendidas suas necessidades básicas, sob pena de perecimento). É que, na ausência de gratuidade de parte das atividades ou dos resultados destas ("despossessão do coletivo natural-mínimo"), a espécie humana sequer se reproduziria. 
Assim, a relação em causa veio a ser paradigma para se questionar a procedência das próprias relações sociais, à medida que, nestas, houvesse inserção real-concretamente voluntária. Enfim, esse paradigma acabou em práxis docente empreendida de modo radicalmente opcional, conquanto por apenas um punhado de voluntários. Todavia, foi o bastante para deflagrar surpreendente mudança na ambiência interna da IES, no sentido de também se ir ao encontro do desenvolvimento da pessoa do estudante, desde que teores disciplinares também acabem mediados por produzir inequívoco e por ensino e aprendizagem avaliados também por produção.

Entrementes, sobreveio uma heteronômica determinação de a IES sujeitar-se a responder às demandas sociais com pertinência, qualidade e internacionalização, assim como de se transformar, segundo Chauí (1999a, p. 218-219), de instituição em organização - esta última, a ser funcional, operacional e resultativa. Tal determinação passou a ser objeto de compulsórias avaliações internas e externas. De imediato, tornou-se imperativo elaborar uma proposta institucional de mudança, a qual teria de ser periodicamente atualizada.

Por seminais que ainda fossem, as atuações daqueles poucos e voluntários pioneiros passaram a concretizar a proposta em causa. Assim, autoafirmação pedagógica veio a encontrar oportunidade para ao menos respirar. Logo a seguir, entrou em pauta uma hipótese de trabalho, cuja justificativa se voltava para um possível elo entre inequivocação quanto a produzir e fúria burocratizante. Esta fúria teria tudo a ver com a necessidade ou o problema de que acabasse solucionado o que tem feito existir a própria burocracia, ou seja, inciência quanto ao que há de constituir solução, peculiarmente em questões de qualidade educacional. Então, bastaria buscar, 
compromissada e honestamente, veracidade sobre qualificação do processo educativo, para que até mesmo a burocracia viesse a ser atendida.

Inicialmente, um tentáculo interno da burocracia - no caso, uma Comissão Própria de Autoavaliação - houve de obter apoio na proposta de autoafirmação pedagógica, o que houve de resultar em teste de atendimento da mais extensa e imperiosa burocracia externa.

Já em crucial necessidade de dinamizar o processo da autoafirmação pedagógica, uma oportuna iniciativa políticoinstitucional interveio no contexto. Foi, então, deflagrado um programa de apoio à docência. Este tem permitido unir hipóteses sob pesquisa-ação com práticas da relação entre ensino e aprendizagem, fenômeno que, gradativa e inusitadamente, veio a ser assumido como práxis a se coletivizar. No âmbito desta práxis, a difusão da proposta de autoafirmação pedagógica passou a se dinamizar. O caráter voluntário da cooperação, sem apelo a "proselitismo", expandiu-se e se intensificou, uma vez que liberdade para anuir é critério inalienável da qualidade já em franca busca. 



\section{Problematização quanto a qualidade e a cientificidade}

Inexiste determinação explícita do que deva ser entendido por qualidade do processo educativo, a par de que cientificidade deste mesmo processo não está intersubjetivamente a ser admitida como questão também qualificadora. A aceitação de que ciências, ética e arte-estética compõem a totalidade educativa ainda não se tornou condição em cuja prevalência se considere qualificativo inteirar o que há de compor a própria educação. Contrariamente, ciências estariam a caminho de ser excludente objeto desse processo. Neste aspecto, um mensurado nível mais alto de desempenho na aprendizagem estritamente de ciências passaria a ser aceitável como educação de qualidade. Assim, recorrência de "a" qualidade no discurso institucional-avaliativo das instituições educacionais traduz uma necessidade cuja persistente imprecisão transforma qualidade e cientificidade do processo educativo em um problema de inconsistência de concepções.

Já a obrigatoriedade de avaliação institucional, interna e externamente processada, tem por fulcro "padrões mínimos de qualidade de ensino, definidos como a variedade e quantidade mínimas, por aluno, de insumos indispensáveis ao desenvolvimento do processo de ensino-aprendizagem" (Lei 9.394 de 20.12.1996, Art. 4 , IX. Grifos nossos). Assim, ao se considerar que nos dicionários filosóficos não consta padrão como categoria, recorre-se a determinado léxico (BUENO, 
1988), nos quais o termo significa modelo oficial de peso e de medida. Paralelamente, insumos evocam teoria geral de sistemas. Então, na ausência de um sistema rigorosamente determinado como científico, restam poucas dúvidas de que o texto legal desvela tentativa de não adentrar o labirinto das inconsistências em que se situa a questão de "a" qualidade. Já esta questão há de continuar exposta a desvarios de ficção propagandista, em duas principais vertentes: (a) alegações de interesse institucional-público; e, (b) tácitas interessenças no âmbito da competição entre organizações privadas.

Se a lei se omite, as autoridades educacionais passam a legislar, à margem das atribuições próprias, sem avançar, senão retroceder, em tal questão. Disto tem sido inegável sintoma a determinação de mensurar qualidade, mediante expedientes de vezo sistêmico, recorrendo-se a exames de assimilação de acumuladas narrativas de saberes tidas por conhecimentos nos níveis de alunos ingressantes e de concluintes do processo de ensino-aprendizagem. Entretanto, desde Aristóteles (apud ABBAGNANO: 2007, p. 957-8), qualidade coincide com "qualquer determinação de um objeto" em resposta à pergunta "qual?", ultrapassando as propriedades ou características quantificáveis de tal objeto, as quais, na atualidade da concepção, perfazem condição secundária das determinações, enquanto a condição primária permanece fora do espaço perceptivo, em "um $x$ vazio" que, para Husserl (Ibid.) "se torna portador das determinações matemáticas e das fórmulas inerentes".

Em síntese, os educandos resultam nas principais vítimas da imprecisão sobre o que seja qualidade educacional e sobre a relação desta qualidade com eventual alcance científico do processo de ensino-aprendizagem. Não há ética e, inclusive, honestidade nos discursos a respeito. Mas, cabe engendrar ao 
menos hipótese de que tais discursos sejam deseducativos e que ultrapassá-los resultaria educativo.

Todavia, até a mera fundamentação dessa hipótese se vê ameaçada de incidir em iniciativa que se expõe a riscos de ser inconsequente, por enredar-se no paradoxo de estar coagida a atender ficção ilusionista e, ao mesmo tempo, buscar veracidade real. É o que, nesta unidade do texto, cabe peculiarmente problematizar.

Qualidade e cientificidade de educação universitária não têm emergido desalheadas em relação ao viés metropolístico de mero ensino superior. A inferência deste viés não está pronta, convindo investigá-lo em fontes caracterizadas por abertura crítica ${ }^{1}$.

Trata-se, a rigor, de recorrente e predizível silêncio quanto a se aperceber de que metropolismo coincide com sincrônico-topocentria, ou seja, com a cultural-artificialmente criada matriz de contraditórios - a tríade compreendida por hegemonismo político, abstracionismo epistemológico e reducionismo econômico.

$\mathrm{Na}$ estrutura dessa tríade, cujos tentáculos sustentatórios de tributação, de contribuições e de retornos (líquidos de tributação e de contribuições) açambarcam todas as fontes de meios de vida, não há como isentar as IES, inclusive as latino-americanas, de perfazerem o suporte gnoseológico de tal açambarcamento.

1 Dentre tais fontes, cabe destacar: CUNHA: 1978; 1983; 1983; 1988; 1989; 1999. DIAS SOBRINHO: 1999. CHAUÍ: 1999a; 1999b. RIBEIRO: 1969; NUNES: 1999b. Paralelamente, crítica e/ou defesa do viés metropolístico de todo o processo educativo caberia constar de fontes que abordem a influência liberal e neo-liberalista nesse processo, a exemplo de SILVA, 2002. LOMBARDI (Org.), 2003. LOMBARDI; SAVIANI; SANFELICE (Orgs.), 2005. SOUZA, 2005. 
Assim, viés metropolístico traduz o que, segundo Novaski (2005, p. 79-85), compõe algo de oculto no fenômeno do ensino superior, peculiarmente da pós-graduação "stricto sensu", além de incidir em funcionalidade sociológica ao "espírito do capitalismo" que, na Civilização Ocidental a se tornar global, move o "desenvolvimento universal em seu valor e significado” (WEBER: 1983, p. 1. Grifo no original).

\section{A. Concomitância de imprecisão sobre qualidade e de ameaça vinculada à obrigatoriedade de avaliação externa}

(Auto)-avaliação institucional é concepção que deriva de uma política educacional (declarada) pública no âmbito do macrossistema MEC-Inep. As implicações dessa política estão a merecer pesquisa e reflexão, peculiarmente da parte de responsáveis por faculdades particulares, isoladas e interiorizadas, a exemplo da IES em apreço - a Faculdade São Francisco de Barreiras/BA (FASB).

De antemão, e neste exemplo pelo menos, cumpre elucidar que (auto)-avaliação institucional se tornou inescapavelmente compulsória e, por isto, traduz-se em tensão dialética entre ameaça externa e oportunidade interna, a primeira de feitio burocrático-estratégico e a segunda administrativo-organizacional. Assim, caracterizar os teores dessa tensão, assim como as forças que os impulsionam, a par de certas implicações de sua (re)-produção, vem a ser o objetivo fundamental deste tópico a investigar.

Torna-se oportunidade interna no sentido de que há como induzir mudança, continuidade ou correção de rumos das atividades acadêmicas (ensino, pesquisa e extensão), 
precipitando estreitamento de interações nos três principais níveis institucionais: mantenedores (e seus funcionários), docentes e discentes.

Já a ameaça externa carece de atenção pouco ou nada encontradiça no pertinente marco regulamentar, bem como nas práticas avaliativas (à base de planejamento estratégico, acompanhamento e controle). Trata-se de ameaça que advém da condição de tais práticas compreenderem conteúdos imprecisos, fragmentados, extensos e pouco ou nada autopoliciados contra eventual mediação de tendências meramente ideológicas, além de estarem em franca dissonância com o alcance englobalizante, moldador e até reducionista, dos procedimentos avaliativos, quer de instituições, quer de cursos, quer ainda de estudantes. Ademais, são procedimentos que não se pautam em bases pedagógicas, mas antes em teorias administrativas cujo suporte metódico é integrado por recorrência e similaridade de pertinentes práticas e, por isto, disfuncional a mudanças de menos duvidoso sentido qualitativo e, a rigor, de precisão científica. Então, para prevenir riscos de sucumbir a tal ameaça e, coincidentemente, favorecer mudança, há urgente necessidade de contra-avaliar a atual política educacional (declarada) pública.

$\mathrm{Na}$ tentativa de atender essa necessidade, cabe formular ao menos hipótese de trabalho, a qual emerge desdobrada em três aspectos básicos: (a) é admissível que, entre si, coincidam alcance crítico da qualidade educacional a ser promovida pela IES e responsabilidade social dos egressos, desde que tal promoção se entenda interiorizada nos alcances tanto sociogeográfico quanto individual-subjetivo do educando; (b) até a mera abertura à busca de qualidade educacional assim crítica necessita de argumentação ainda inaudita, pois, de outra forma, pesquisadores hão de estatelar-se contra 
um intervencionismo que tem sido radicalmente alheado à dissonância entre "status" (dos teores do marco legal-regulamentar em que se escuda) e ímpeto reducionista (das práticas administrativas, mediante as quais insiste em se afirmar); e (c) procedimentos autoavaliativos, coerentes com um discurso ainda não usual de argumentação, carecem de projetos tecno-cientificamente validáveis, além de libertos em relação à compulsoriedade, vale dizer, sem desta serem vítimas e tampouco cúmplices.

Antes de tudo o mais, cumpre deixar claro que procedência, veracidade e validade, referentes ao que deverá corroborar os teores da hipótese em apreço, reportam-se a objetos aos quais se chega por procedimentos "interdisciplinares", cujo suporte metódico medeie por entre inequivocação quanto produzir intelectualmente (tirante a um avanço na "maiêutica” socrática) e regras cientificizantes do método.

Já a justificativa de um tal suporte metódico reside na situação da fonte do olhar que possibilita percepção e, graças a esta, discernimento pessoal entre apropriar e produzir, desde educação e conhecimentos, passando por meios de vida, até condições de sustentação também coletiva. Todavia, tal discernimento se circunscreve a estrita mediação e jamais substitui pertinência e cientificidade de outros conhecimentos disponíveis. 


\section{B. Concepção de qualidade, heteronomica- mente exposta a disputas ideológicas}

\section{Imprecisões da qualidade sob disputa}

$\mathrm{Na}$ vigente Constituição Federal, a questão da qualidade de ensino emerge correlata a qualificação para o trabalho, a par de promover o "pleno desenvolvimento da pessoa", em pé de igualdade com o também pessoal "preparo para o exercício da cidadania" (Art. 205). Assim, e em termos propriamente legitimados, a qualidade de ensino implicaria considerar a pessoa do educando. Mas, e apesar desta implicação, contará com um princípio de padrão assegurável (Art. 206, Inciso VII $)^{2}$. Ademais, será passível de implementação pela iniciativa privada (Art. 209, Caput), conquanto não sejam dispensadas autorização e avaliação por parte do Poder Público (Inciso II). Assim, e ainda que de forma implícita, precisará de melhoria a ser avaliada no âmbito de um plurianual plano nacional de educação (Art. 214, Inciso III).

Enquanto a Lei Maior se refere a ensino de todos os níveis, a LDB assume "educação escolar, que se desenvolve, predominantemente, por meio de ensino em instituições próprias" e que deverá vincular-se ao "mundo do trabalho" e à "prática social" (Art. $1^{\circ}$, IS $1^{\circ}$ e $2^{\circ}$ ). Nesta perspectiva, a LDB acaba por não mais do que subsumir desenvolvimento da pessoa, ao interpretar qualidade, determinada pela Lei Maior, como

2 Peculiarmente por se tratar de um princípio de seguimento compulsório ao se ministrar ensino, "garantia de padrão de qualidade" é determinação incompatível com o (jamais padronizável) caráter singular-pessoal da qualidade a ser efetivamente implementada. Assim, ultrapassagem dessa incompatibilidade postularia expressões diversas daquela de "qualidade garantida por padrões de condições de oferta" e que prevaleceu no texto da LDB (Inciso IX, Art. $4^{\circ}$, Lei $n^{\circ}$ 9.394, de 20.12.1996). 
ensino mediado por "educação, dever da família e do Estado, inspirada nos princípios de liberdade e nos ideais de solidariedade humana" (Art. $2^{\circ}$ ). A par disso, ensaia realimentar o entendimento de que qualidade seja assunto em cujo teor precisem coincidir institucionalidade e sustentabilidade, além de manter imprecisão sobre qualidade na interação entre pessoa e trabalho, ao repetir a expressão: “(...) insumos indispensáveis ao desenvolvimento do processo de ensino-aprendizagem" (Art. $4^{\circ}$, Inciso IX. Grifo nosso). Em decorrência, é assegurado "em primeiro lugar o acesso ao ensino obrigatório" (Art. 5 , $\$$ $2^{\circ}$ ), e, paralelamente, imputa-se "crime de responsabilidade" no caso de comprovada negligência da autoridade envolvida $\left(\$ 4^{\circ}\right)$. Por outra parte, resta cabalmente implícito que em tais insumos se enquadrem infraestrutura e demais recursos material-técnicos, bem como, a despeito da pessoalidade das condutas a tanto imprescindíveis, docentes cujos perfis a tanto hão de coadunar-se, quanto mais elevados forem os respectivos títulos ou aprofundadas as correspondentes especialidades de tipo de conhecimento e de método.

Conforme Botomé (1996, p. 27-29) a formação de docente de nível universitário presume, além de ser professor, outras quatro profissões - técnico e especialista; pesquisador ou cientista; administrador; e, escritor. Para tanto, a preparação tem sido desigual, além de que a pós-graduação "stricto sensu" tende a intensificar a especialização técnica em um só assunto e no recurso a "algumas (quando não uma única!) técnicas de pesquisa”. Assim, esse profissional há de encarar certos desafios.

[...] desenvolve uma "experiência" que, com frequência muito grande, não o leva a completar as lacunas em sua formação, mas a desenvolver e fortalecer o que é "aceito", o que "funciona" ou 
o que lhe dá "poder", "capacidade de influência", etc. no meio social e institucional. Com isso, consolida-se, progressivamente, um poder cada vez maior (...) que o leva a agir sobre os demais e sobre a instituição de maneira a consolidar não o que vale a pena a longo prazo, para a instituição e para a sociedade, mas o que o leva a "ganhar", "sentir-se seguro", "obter mais poder", "ser aceito e reconhecido", etc. (BOTOMÉ, 1996, p. 27).

A propósito desse risco no processar-se da profissão de professor universitário, cumpre autopoliciamento no sentido de prevenir dissonância de concepções sobre qualidade educacional, inclusive entre avaliadores institucionais, externos e/ou internos.

Apesar do entendimento da LDB sobre educação, bem como da determinação constitucional (Art. 209) a propósito da presença e da sustentação de instituições privadas nas atividades de ensino, há lacunas no pertinente marco regulamentar. As atividades das IES privadas acabam inseridas no mero varejo da regulamentação cabível, assim como à obrigatoriedade de processos burocráticos desfocados quanto à devida pertinência à questão real e socialmente relevante, vale dizer, quanto à referida qualidade educacional na interação entre pessoa e trabalho. Neste sentido, cumpre ressaltar que pesquisa e extensão das IES filantrópicas de direito civil estão constitucionalmente legitimadas a receber recursos do Poder Público (Art. 213, $\ 2^{\circ}$ ). Entretanto, e a princípio, a avaliação institucional externa está legitimada a prejudicar tais IES, à conta de alegadas insuficiências de extensão e, peculiarmente, da circunstância de as cabíveis atividades 
avaliativas incidirem em custos que precisam recair sobre as mensalidades, a ponto de isto significar exclusão à margem de candidatos a estudantes. Ademais, e por força das mencionadas lacunas, proliferam entendimentos imprecisos sobre qualidade e tende a ser enfraquecida sua pertinência ao fenômeno propriamente educacional, a exemplo dos seguintes: (qualidade) de ambiente de trabalho (Parecer CES, no 908/98); (qualidade) determinada por fatores diversos e abrangidos por procedimentos e critérios avaliativos (Lei 9.131/95, Art. 3º); e, (qualidade) de pessoas jurídicas de direito civil, sem fins lucrativos (Decreto no 3.100/99).

Peculiarmente, cabe maior atenção ao entendimento de qualidade educacional no âmbito do macrossistema MECInep, âmbito em que dois ciclos precisam vir diferenciados: (a) ao longo da deflagração da avaliação das IES no sistema federal de ensino superior (na elaboração, tramitação e divulgação da Lei $\mathrm{N}^{\circ}$ 10.861, de 14.04.04, bem como da Portaria $\mathrm{N}^{\circ}$ 2.051, de 09.07.04); e (b) após o teste de campo da obrigatoriedade da autoavaliação institucional das IES particulares (elaboração e divulgação do texto sobre Diretrizes e Instrumento da Avaliação Externa de Instituições de Educação Superior, bem como do Decreto $N^{\circ}$ 5.773, de 09.05.06).

$\mathrm{Na}$ deflagração em causa, houve de emergir entendimento sobre qualidade das autoavaliações, se nestas houver participação dos seus sujeitos - corpos docente, discente e técnico-adminitrativo (MEC/Conaes: s/d, p. 5). Vem a ser qualidade que é passível de patamares e estes devem refletir transformações e mudanças (p. 7). Também significa compromisso com a melhoria da própria qualidade das atividades de cada uma e do conjunto das instituições educacionais ( $\mathrm{p}$. 8). Aparece ainda uma "qualidade do sistema de educação superior" (p. 9). A seguir, como instrumento de política 
educacional, surgem outros entendimentos sobre qualidade, nos quais esta aparece não apenas passível de melhoria e pertinente às atividades de formação de futuros egressos, como também de produção de conhecimentos e de extensão no estrito âmbito de cada IES (p. 9). Há, ainda, qualidade de um bem público, a própria educação, se esta for promovida em acordo com princípios (p. 13), ou que seja "compatível com modalidades de ensino, pesquisa e extensão (p. 17)3. Por fim, cabe destacar uma qualidade institucional que não pode provir de fora e na condição de modelo externo e abstrato, mas precisa ser, em cada IES, "modelo institucional nos termos de sua missão e, a partir dele, deve ser avaliada a instituição real” (p. 18).

Após o teste de campo da obrigatoriedade da autoavaliação das IES, especialmente (e tacitamente) das particulares, o entendimento sobre qualidade tende a desandar em construto, a atingir patamares sempre mais altos e pertinentes à educação superior brasileira em seu conjunto (MEC/Conaes/Inep,

3 Dentre os 7 (sete) princípios arrolados, os 2 (dois) primeiros são preocupantes: $\left(1^{\circ}\right)$ "A responsabilidade social com a qualidade da educação", o qual intriga por ter sido eleito sem ouvir os sujeitos ou agentes, ou seja, a despeito da recorrência e da predizibilidade de conflitos entre autoridade administrativa (MEC/Conaes/Inep) e autoridade de especialista, esta última sendo peculiar a instituições universitárias, ou mesmo, de estrita pesquisa, assim como de tensões organizacionais entre informalidade e formalidade, entre clientes e organização, ou ainda, entre profissionalidade e disciplina burocrática, paralelamente àquela peculiar tensão entre necessidade de iniciativa individual, como imprescindível fonte de criatividade, e planejamento centralizado enquanto veiculador de se recorrer a meios tecnológicos cujo avanço, ao se converter em um fim em si mesmo, inibe criatividade" (MUNIZ; FARIA, 2001, p. 73-74); e $\left(2^{\circ}\right)$ "O reconhecimento da diversidade do sistema", o qual também intriga por dar margem a pretexto de as instituições educacionais públicas acabarem por omitir-se quanto à qualidade educacional inerente à interação entre pessoa e trabalho (alheamento ao problema de a falta de solução ser tida como a própria solução, dada uma conveniente inciência quanto a tributos, e não apenas retornos privados, precipitarem insustentabilidade coletiva). 
2005, p. 4), assim como a ser cultural, verificável (mediante avaliação externa) e atribuível à instituição e à formação dos estudantes (p. 7). Também passa a ser pertinente a processos a serem realizados, assim como à atuação acadêmica e social, além de ser objeto de compromisso e atributo de informações e do sistema como um todo (p. 8). É objeto de destaque, por ser de per si condizente com instituições de educação, sendo, neste aspecto, passível de promoção e referente a processos educativos e científicos (os quais incidem "em uma prática social que afeta e modifica as pessoas, assume perspectiva histórica, plena de sentidos e valores"), assim como atributo, ou conjunto de atributos, do cumprimento da missão de forma a satisfazer expectativas internas dos sujeitos da comunidade acadêmica e externas da sociedade, com padrões aceitáveis de desempenho (p. 8). Resulta referenciada por "estatuto de responsabilidade democrática”, devido a ser promovida pela combinação de critérios científicos e de participação dos atores acadêmicos e sociais (p. 8). Detém valor, definível por parâmetros e, por isso, tende a reinterpretar pertinentes padrões. Estes devem ampliar, ilimitadamente inclusive, o seu significado legal de "insumos" por educando, atendendo tanto a objetivos que, por sua vez, direcionam o processo educativo, quanto a projeto pedagógico e científico da IES (p. 9). Apresenta-se sob referentes que emergem em alcance tanto universal quanto particular. No primeiro caso, tais referentes são compreendidos por “(...) a adequação e a pertinência dos processos de formação, o rigor acadêmico e científico, a condição social, científica e cultural da produção acadêmica, a construção da cidadania e o exercício da democracia" (p. 9). No segundo caso, esses mesmos referentes são específicos (ou) particulares, desde que "vinculados à missão de um conjunto de instituições ou de uma só instituição, que reafirmam as suas peculiaridades e caracterizam seus propósitos 
autoinstituídos" (teor da missão própria e coerência, com este teor, do projeto pedagógico institucional, bem assim com "contextos, atores, processos e atividades, dando atenção às especificidades e, ao mesmo tempo, permitindo o delineamento de uma visão global da instituição" (p. 9). Ademais, (e enquanto institucional) tem "indicadores, em distintos níveis e enfoques", os quais são passíveis de construção e consolidação por diretrizes para a avaliação externa das IES (p. 10). Já enquanto assim passíveis, dependem de exercício permanente de autorreflexão à base de referentes universais e particulares (p. 11). Além disso, e na condição de atributo de informações, incidem em bases (qualitativas) da avaliação externa, bases que "são estruturadas a partir da análise do referencial quantitativo (também de informações) e da comparação, em diferentes níveis de observação, entre o que a IES se propõe a cumprir e a sua capacidade para tal" (p. 12) ${ }^{4}$.

Enfim, e após tantos entendimentos sobre qualidade, em nada surpreende que esta acabe definida de forma circular (o definido, ocorrendo no que o define), inclusive em assertivas de decisiva relevância para a operacionalidade do processo de avaliação externa.

4 A comparação aponta para um desajuste entre situação projetada e situação atingida de atividades acadêmicas, cuja qualidade, diversamente do admitido, há que provir dos respectivos valores intrínsecos ou dos motivos pelos quais, para tanto, acabaram eleitas. Não há máxima aproximação entre as duas situações, questão que se traduz também como riscos interpretativos dos seguintes dizeres (sic): "As bases qualitativas são estruturadas a partir da análise do referencial quantitativo e da comparação, em diferentes níveis de observação, entre o que a IES se propõe a cumprir e a sua capacidade para tal" (p. 12. Grifo nosso). As qualidades objetivas (determinações matemáticas e fórmulas inerentes), segundo Abbagnano (2007, p. 958. Grifo nosso), “... delineariam a natureza de um objeto transcendente à percepção sensível, ao qual esta acenaria como a algo distante”. Em suma, resta cômico, se não fosse trágico, fazer escarcéu midiático, seguido de ameaças de sanções institucionais, à conta de notas arbitrariamente atribuídas a uma IES. 
A dimensão qualitativa tem o objetivo de captar os movimentos institucionais na direção das referências de qualidade estabelecidas nas dez dimensões ${ }^{5}$ do sistema Nacional de Avaliação. A avaliação qualitativa desenvolve-se a partir de indicadores que objetivam compreender e analisar a qualidade dos processos e práticas vivenciados, em uma perspectiva dinâmica e auto-referenciada ( $\mathrm{p}$. 12. Grifos nossos).

A ocorrência do definido na definição desvela a circunstância de que os teores desse excerto de texto destinam-se a avaliadores externos, cuja iniciação lhes favorece entender os próprios entendimentos. Entretanto, avaliadores não assim iniciados têm de admitir que imprecisões conceituais estão a permear situação interna e superposição externa de avaliações, urgindo dar conta da circularidade desses teores.

Após tantas apreciações de entendimentos sobre qualidade, cuja melhoria vem a ser o objetivo justificador das avaliações, internas e externas, há três tendências a levantar: (a) intensifica-se imprecisão sobre significado de qualidade, inclusive enquanto mero atributo de atividades acadêmicas, sem que se desconfie da influência do metropolismo nos contrafortes

5 As dez dimensões são as seguintes: (1 ${ }^{a}$.) a missão e o plano de desenvolvimento institucional; $\left(2^{\mathrm{a}}\right.$.) perspectiva científica e pedagógica formadora: políticas, normas e estímulos para o ensino, a pesquisa e a extensão; $\left(3^{a}\right.$.) responsabilidade social da IES (nas perspectivas da inclusão social, do desenvolvimento econômico e social, meio-ambiente e preservação da memória e do patrimônio cultural); $\left(4^{\mathrm{a}}\right.$.) comunicação com a sociedade; (5 ${ }^{\mathrm{a}}$.) políticas de pessoal, carreira, aperfeiçoamento e condições de trabalho; $\left(6^{a}\right.$.) organização e gestão da instituição; $\left(7^{\mathrm{a}}\right.$.) infraestrutura física e recursos de apoio; $\left(8^{\mathrm{a}}\right.$.) planejamento e avaliação; $\left(9^{\mathrm{a}}\right.$.) políticas de atendimento aos estudantes; e, $\left(10^{\mathrm{a}}\right.$.) sustentabilidade financeira. 
dos discursos oficial e oficioso; (b) a concepção de qualidade enquanto algo inerente à interação entre pessoa e trabalho, apesar de seu "status" constitucional, acaba em sempre menos oportunidades de vir a ser considerada, concomitantemente com a (inconfessa) pretensão de os procedimentos metódicos sobre-estarem ao sujeito, e até mesmo ao objeto, e perfazerem inescapável condição para as ciências se autoafirmarem como domínio único da produção do (auto)-conhecimento de instituição educacional, preterindo-se ética e arte-estética na totalidade educacional; e (c) procedimentos avaliativos passam a ter muito em comum, peculiarmente, práticas administrativas de planejamento estratégico (análise de ambiências para constatação de oportunidades, ameaças, pontos fortes e fracos, a par do apontamento de objetivos, da fixação de metas, da eleição e execução de ações, do acompanhamento e do controle), circunstância que favorece reciprocidade de contágio (e de isenção) quanto à própria falta de qualidade.

\section{Procedimentos autoavaliativos: do alcance estratégico ao caráter "crítico-teoricamente" autoafirmativo}

Para a (inicialmente referida) argumentação ser deflagrada, procura-se demonstrar, neste tópico de texto, que o macrossistema MEC-Inep expõe-se a riscos demasiadamente amplos de assumir imprecisão de componentes de suporte metódico, à medida que os procedimentos avaliativos do ensino superior ocorrem compreendidos em práticas administrativas de planejamento estratégico, práticas que estão a se defrontar com questionamento quanto à sua fundamentação, científica inclusive. 
À primeira vista, tal ocorrência seria justificável, uma vez que, por ora, estaria em pauta apenas a delimitação de um problema de fundo e ainda não mais do que vislumbrado, para não dizer, vitimado a preconceitos: aquele de uma (pré-conceituada e) contínua perda de qualidade por parte do ensino superior que vem sendo promovido, especialmente, pelo segmento privado do correspondente sistema federal. Todavia, até mesmo essa eventual delimitação do problema depara-se com dissonância entre estratégia de política pública sobre qualidade educacional e procedimentos avaliativos desta mesma qualidade.

Estratégia de política pública não tem sido caracterizada por abrangência universalista em sociedades originárias e herdeiras das práticas colonialistas, uma vez que universalismo não veio merecendo atenção nem mesmo nas próprias metrópoles - no caso, Lisboa ou o patrimonialismo junto às cortes portuguesas e, após a independência política, junto a certa elite cuja ampliada reprodução tem tudo a ver com a universidade (que se vem declarando) pública e inclusive filantrópica. Assim, e em tais sociedades, sequer a possibilidade de universalismo, a respeito do que é público, chegou a merecer atenção à altura da pertinente densidade e aprofundamento conceitual. Eis porque, no Brasil, as políticas públicas têm acontecido em relação a públicos-meta (-alvo ou -foco). É que a (presumida) impossibilidade de aquelas políticas serem universalizáveis tem feito com que haja incursão em dualismo legal-regulamentar a respeito de inclusão e exclusão - ambas quanto a acesso à condição de meta, alvo ou foco. Já esse dualismo tem muito a ver com a arraigada assimetria entre resignação e "arrogância reivindicalista" junto às populações nas quais subsiste enraizado. Trata-se de assimetria cuja reprodução muito tem a ver com o "status" legal-regulamentar de intérpretes do alcance público das políticas, a partir da sua (silenciada) situação de incluídos. 
Por implícito que o esteja, dualismo legal-regulamentar também tem sido influente na interpretação do alcance público da política educacional. Trata-se de interpretação cuja fonte não se apercebe de que o seu olhar parte da situação do próprio "status" de sobrepor-se, desde à resignação a insuficiências até à "arrogância reivindicalista" de suficiências, em todos os níveis do processo educativo (infantil, fundamental, médio, superior, pós-graduação). Assim, o alcance do que se admite como público, anteposto a meta, alvo ou foco, costuma vir traduzido como o próprio sobrepor-se, porque este se universaliza na condição de teor político-hegemônico, metódico-epistemológico e material-econômico. Por sua vez, este teor tem estado a cavaleiro de uma vontade que, ao imiscuir-se com desejo (pessoal e/ou corporativamente) incontido, incide em equívocos quanto a seu sentido de coletiva, pública ou universalizada. E, no bojo de tal imiscuição, não há como o atributo (dito) público de uma política apresentar-se com significado construtivo de qualidade, nem mesmo se esta atendesse a (compulsória ou legal-regulamentar) "perspectiva científica e pedagógica formadora" da mais significativa das 10 (dez) dimensões institucionais a serem avaliadas. Ademais, só após o teste de campo dos procedimentos autoavaliativos, tal perspectiva veio a ser menos imprecisamente definida. Isto ocorreu a partir do entendimento que veio a ter a dimensão em causa (a segunda, dentre as inicialmente eleitas, referente a "políticas, normas e estímulos para ensino, pesquisa e extensão") no marco regulamentar das diretrizes para avaliação externa das instituições educacionais (MEC/Conaes/Inep: 2005, 21) ${ }^{6}$.

6 Apesar da explicitação dos conteúdos ter ficado menos imprecisa, resta ainda a implicitude de que "a perspectiva ... pedagógica formadora" não seja científica e, então, ficaria irreconhecível seu significado contributivo para a qualidade. Todavia, com certa boa vontade, há como assumir que pedagógico-formadora seja pertinente ao alcance científico da perspectiva. 
Tal entendimento passou a ser compulsório, além de a relevância da dimensão em foco se tornar mais expressiva (de $10 \%$ para $30 \%$ do total), no sentido de contribuir para a apontada melhoria da qualidade do ensino superior. Esta passagem entrou em dissonância com a (também legal) relevância igualitária dessa mesma dimensão no contexto das 9 (nove) outras, porém, após acabar entendida à base de conteúdos significativamente diversos (sic): "a política para o ensino, a pesquisa, a pós-graduação, a extensão e as respectivas formas de operacionalização, incluídos os procedimentos para estímulo à produção acadêmica, as bolsas de pesquisa, de monitoria e demais modalidades" (item II, art. 3º Lei No 10.861, de 14.04.04).

A própria instituição do Sinaes fora deflagrada como especialidade de política pública em franca dissonância com o alcance universalizado da avaliação a ser promovida. Trata-se de dissonância, em que transparece certa discriminação entre as próprias finalidades do correspondente sistema, conforme os termos do seguinte excerto da pertinente regulamentação.

O SINAES tem por finalidades a melhoria da qualidade da educação superior, a orientação da expansão da sua oferta, o aumento permanente da sua eficácia institucional e efetividade acadêmica e social e, especialmente, a promoção do aprofundamento dos compromissos e responsabilidades sociais das instituições de educação superior, por meio da valorização de sua missão pública, da promoção dos valores democráticos, do respeito à diferença e à diversidade, da afirmação 
da autonomia e da identidade institucional. (Art. $1^{\circ}$, Lei $\mathrm{N}^{\circ}$ 10.861, de 14.04.04. Grifo nosso $)$.

Antes que se ouse interpretar qualidade presente nesse excerto de lei, cumpre alertar que o significado da (pleonástica) expressão "melhoria da qualidade" pretende escudar-se em práticas (bases empíricas) e advirá de uma agregação (traduzida quantitativamente, mediante pesos) de notas (de 1 a 5), exaradas a meio-termo entre objetividade e subjetividade pelos próprios avaliadores, além de se referirem a fenômenos heterogêneos e numerosos. Dessa forma, o recurso a tais notas, para fins de política pública, há que satisfazer um escalar, cujos patamares se traduzem em nada mais do que violência aos fundamentos inescapavelmente singular-particulares do que seja qualidade real quanto a desenvolvimento da pessoa, qualidade já anteriormente definida pela Constituição Federal (Art. 205) e imprecisamente assumida na LDB (Art. $1^{\circ}$, Caput e $\ 2^{\circ}$ ). A mesma tradução deverá vir admitida a propósito de outras expressões, nas quais são insinuadas as categorias correspondentes a eficácia, efetividade, missão e orientação. Por outra parte, não cabe sequer traduzir em conceitos os fundamentos reais correspondentes aos termos: compromissos, responsabilidades, valores, diferença, diversidade, autonomia e identidade, os quais presumem desenvolvimento pessoal, vale dizer, conduta que o desvele.

7 A razão do grifo em "especialmente" reside em certa incoerência entre discurso legal-regulamentar e prática avaliativa, pois a responsabilidade social das IES vem a ser a dimensão 3 dentre as 10 (dez) a serem avaliadas e que, nas diretrizes mais recentemente publicadas, passou a ter peso não compatível com a ênfase assim grifada - apenas $10 \%$, contra $30 \%$ da 2 e $20 \%$ da 5 . (Ver: MEC/Conaes/ Inep. Op. cit. p 21). 
Por preliminares que o sejam, essas considerações servem para argumentar na perspectiva de que a Conaes optou por fazer análises intra- e interorganizacionais com propósitos estratégicos de planejamento, abdicando de recorrer a suporte metódico de pesquisa qualitativa que partisse de um problema suficientemente caracterizado e que lhe possibilitasse solução como objeto denso e aprofundado de conhecimento novo e já imprescindível à causa da educação criticamente universitária. Todavia, com boa vontade e com apelos ideológicos de largo alcance, concede-se que as análises levarão ao fulcro do (presumido ou, talvez, ainda insuficientemente caracterizado) problema federal-sistêmico do ensino superior: meras apostas na (assim dita) contínua melhoria da qualidade, apesar de este ensino ser promovido de forma a buscar ou presumir mais-valia na acepção de "O Capital" (MARX, 1984, p. 246), forma que também prevalece na orientação para a expansão da sua oferta, no desejado aumento da sua eficácia institucional e efetividade acadêmica e social e, especialmente, na ausência de autopoliciamento contra a superficialidade de iniciativas institucionais descompromissadas e socialmente irresponsáveis, as quais, a cavaleiro da missão pública de tal ensino, presumiriam valores democráticos, respeito à diferença e à diversidade, além de afirmação pessoal da autonomia e da identidade - ambas institucionalmente promovidas.

Uma análise, ainda que ligeira, da condição especial que veicula as finalidades do Sinaes, desvela certo ímpeto fragmentário, competitivo e até mesmo ilusionista, o qual é próprio das práticas administrativas, além de restar sob suspeita de contagiar os procedimentos avaliativos a cargo do macrossistema Conaes-Sinaes-Inep. Dentre os modificativos de tal ímpeto, ressalte-se o de ilusionista, tendo-se em conta que irrompem, entre si dissociadas, as expressões que correspondem à melhoria da qualidade educacional e à responsabilidade social 
da IES. Trata-se de dissociação que tem sido notoriamente funcional a preterir qualidade da educação pessoal-desenvolvimentista e a acentuar insustentabilidade coletiva da própria educação universitária, à medida que responsabilidade social só é considerada enquanto iniciativas institucionais cujas oportunidades de se efetivarem incorrem em custos sempre mais elevados, por terem que acontecer fora da ambiência interna da IES e mediante atividades, programas, projetos e setores, os quais tendem a se departamentalizar nesta mesma ambiência. São custos que desandam em elevação das taxas educacionais, ou seja, em exclusão social de candidatos a cursar o ensino superior particular e inclusive público. Tenha-se em conta, ao menos, a possibilidade de tal exclusão, ao se entender responsabilidade social de forma a não buscar, universalizadamente, desenvolvimento pessoal do educando e, por isto, definida segundo os seguintes termos:

[...] significado de sua (IES) atuação, por meio de suas atividades, cursos, programas, projetos e setores, considerando (...) a responsabilidade social da instituição, considerada especialmente no que se refere à sua contribuição em relação à inclusão social, ao desenvolvimento econômico e social, à defesa do meio ambiente, da memória cultural, da produção artística e do patrimônio cultural" (Lei 10.861, de 14.04.04. Art. $3^{\circ}$, Item III. Grifo nosso).

O "especialmente", a propósito desse entendimento da responsabilidade social, é o que motiva certos questionamentos: em ambiência democrática, compulsão (legalidade-regulação) a agir de modo socialmente responsável deixa de incidir em saída utópica? É possível à educação ultrapassar a mera 
ilustração do educando sobre implicações e desdobramentos de suas condutas? Por que sequer tal ilustração é promovida? Até que ponto uma IES precisaria fazer as vezes de organizações diretamente envolvidas com problemas sociais, uma vez que lhe é próprio prevenir estes problemas, em vez de alienadamente vivenciá-los, deixando de incorrer em custos adicionais (e inúteis) da educação que promove? Democraticamente é plausível impor ônus adicional ao custeio da educação, sem consulta e consentimento dos (há tanto) obrigados, ou seja, os próprios estudantes ou seus familiares no caso de IES particular, bem como os contribuintes no caso das públicas? Por que economia, produção e utilidade precisam estar, liminarmente inclusive, excluídas de permear ambiências educativas? Por que respostas a estas e outras questões não serviriam para fazer coincidir qualidade educacional e responsabilidade social? Contrariamente, por que essas mesmas questões e respostas não deixam de ser nulidades, picuinhas e que tais, no discurso legal-regulamentar que torna compulsório, até mesmo, vezo ilusionista de práticas avaliativas?

Com efeito, compromissos e responsabilidades sociais correspondem a condutas e estas necessariamente coincidiriam com ações apoiadas por narrativas de saberes há tanto contextualizadas. Neste sentido, tal coincidência ainda não passa de utopia no ensino superior brasileiro, não por ser nacional, mas por alargamento da própria inadequação a fomentar conduta que é requerida para efetivar avanços científico-tecnológicos, até mesmo aqueles que sejam responsivos às contingências de competir em perspectiva transnacional e, por isso, acabem dissonantes das contextualizadas necessidades pessoais e coletivas. Trata-se de ensino que favorece mera acumulação de narrativas de saberes tidos por conhecimentos, à medida que vezo evolucionista das condutas tem como aprofundar privilégios individuais, corporativos 
e nacionais. De toda forma, nas atuais possibilidades sociogeográficas dos avanços científico-tecnológicos, não caberia a prepostos da educação propriamente universitária serem omissos quanto a enxergar necessidade e eventual suficiência de alteridade de condutas para fazer frente a compromissos e responsabilidades sociais. Alhear-se a essa omissão tem muito a ver com o vezo ilusionista de práticas administrativas, cujo esgotamento de paradigmas teóricos encontra-se em franca aceitação.

Não coincidência entre qualidade da educação e responsabilidade social dos egressos é concomitante com alheamento científico em relação à interface entre forma de sustentar a educação pública e falta de soluções como se fosse a própria solução da sustentabilidade coletiva. Inversamente, essa mesma interface seria aceitável, ao menos como hipótese, no sentido de que qualidade crítica da educação tenha que ser sustentada por contribuições a tanto arrazoadas, em vez de à custa de tributos. A par dessa aceitação e daquela eventualidade, ainda invalidáveis para escudar políticas públicas relacionadas com a educação, no caso a universitária, convém apresentar outro argumento, aquele de que se justifique - apesar da obrigatoriedade de procedimentos avaliativos definidos pelo MEC (Conaes-Sinaes-Inep) e da pertinente imprecisão sobre qualidade educacional-universitária - uma proposta pedagógica a ser ("interdisciplinar" e alterinamente) validada e que tenha como contribuir para que venham a ser, oportunamente fundamentados, os teores da hipótese de trabalho inicialmente levantada. (A próxima subunidade textual volta-se para apresentar os teores desse argumento). 


\section{Alteridade de argumentação quanto à institucionalidade avaliativo-educacional}

No âmbito do macrossistema MEC-Inep, emerge uma determinação de referentes de qualidade inusitadamente sistêmica (de conjuntos) e elementar (IES, curso e estudante), conforme já acima abordada. No caso de uma faculdade isolada, a qualidade sistêmica acaba, a rigor, arbitrada, mediante a integração de níveis avaliativos: institucional (interna e externa), de curso de graduação (autorização, reconhecimento e renovação) e de desempenho dos estudantes (ENADE).

Não há referência sobre interfaces entre aquela determinação e essa integração, mas resta, pelo menos implícito, que o ENADE é um exame para análise dos "conhecimentos adquiridos ao longo do seu processo de formação" (MEC, 2005 , p. 10). E, por ser feito com base em prova por (universo de) curso, incide em abrangência e integração por além desta ou daquela instituição, assim como em homogeneização e até reducionismo quanto ao perfil do egresso. Em tais circunstâncias, não emerge descabido que se desconfie de funcionalidade sociológica a ideologias hegemônicas.

Adicionalmente a tal desconfiança, subsiste uma interface sobre a qual persiste um intrigante silêncio. Vem a ser a (tacitamente admitida) inconciliabilidade do perfil em causa, não apenas com interiorização (e/ou subjetivação pessoal desenvolvimentista) da qualidade educacional-universitária, mas também com alcance contextualizado de narrativas de saberes e, sobremaneira, com conduta singular-particular vinculada também a inequívoco produzir. Ao contrário, é perfil que se ajusta, com extremada afinidade, à metropolização (tendência à sincrônico-topocentria) de atribuída qualidade, cujo inconfesso impingimento perfaz a soltura 
dos discursos que povoam textos oficiosos, oficiais e até mesmo legal-regulamentares. Ainda que esteja a resultar tão somente de acumulação mais ou menos ampla de narrativas de saberes, trata-se de "a" qualidade que incide em condição de o acadêmico, não apenas obter notas de patamar mais ou menos elevado, como também competir por sucesso profissional socialmente convalidado.

Assim, e por força de alheamento quanto à (presumida) qualidade do ensino superior servir à conotação metropolista deste mesmo ensino, a avaliação institucional, ela própria tende a acabar tácita e acriticamente indiferenciadora, reducionista e simploriamente englobalizante dos fenômenos inerentes ao processo educativo. O principal sintoma dessa indicação reside no lidar avaliativo-institucional que persiste estranhado quanto a entender "insumos" como "docência capaz de desenvolver plenamente pessoas". Sobremaneira, há que salientar a obrigatoriedade de pós-graduação, peculiarmente a "stricto sensu", à medida que educador não faz a menor diferença em relação a outros profissionais que apropriam meros "inputs" para os transformar em "outputs" sistêmicos. Em decorrência, a relevância avaliativo-institucional da mera titularidade dos pós-graduados acaba em primarismo humano, pois a eventualidade de existir atuação inequivocamente educacional de docentes, esta ficaria meramente subentendida na ponderação atribuída à dimensão avaliativa correspondente a "perspectiva científica e pedagógica formadora: políticas, normas e estímulos para o ensino, a pesquisa e a extensão" (30\% do total dos pesos, apesar de que políticas, normas e estímulos difiram de ciência e pedagogia, restringindo-se, enquanto perspectiva formadora, aos "umbigos" delas mesmas), além de que, a rigor, essa dimensão tenha tido que perfazer notória ambiguidade com aquela de "responsabilidade social da IES" (20\%, apesar de o perfil de egresso não ultrapassar a condição 
de mero reprodutor de narrativas de saberes). Afinal, até educadores teriam que refletir o fato de serem egressos com perfil nada mais do que aprofundadamente especializado, ou seja, apenas na razão direta do aquilatado progresso como pósgraduados (pós-doutores, doutores, mestres e especialistas). Não se avalia referente algum que faça diferença como "pleno desenvolvimento pessoal", nem mesmo quanto a autodesenvolvimento pessoal dos docentes.

Se a (recém-mencionada) inconciliabilidade for associada às (acima já apontadas) imprecisões quanto à qualidade educacional, fica indicado que padronização referenciadora de qualidade tem a ver com acumulação máxima de narrativas de saberes, enquanto (pretensa) perspectiva pedagógico-formadora, e com especialização a se aprofundar na razão direta de avanço na pós-graduação. Assim, aquela acumulação e esta especialização ficam suspeitas de "estarem" a serviço de acentuados privilégios ocupacionais que apenas subsistem em estreita cumplicidade com tergiversação sobre o que seja propriamente trabalho, sobremaneira quanto ao pertinente alcance de improdutivo. Trata-se de "estado" a condizer com mero escalar de patamares conceituais sobre qualidade de ensino superior.

A interpretação, recém-explicitada, constitui desdobramento da postura de um olhar cuja fonte não se abstrai do vazio em que se situa, seja na totalidade educacional, seja por entre as instituições sob processo (auto)-avaliativo. Se assim não se postasse, "estaria” cega em relação a tal vazio e o converteria em suas próprias costas. Encontrar-se-ia alhures, perdida no interior do conjunto aberto das organizações e no exterior das especificidades enquanto componentes intraorganizacionais. 
É a partir da admissibilidade dessa interpretação que os três aspectos (inicialmente aventados) da hipótese de trabalho passam a fazer sentido. Fica, então, elucidada a existência de (ao menos) suspeitas quanto à presença da iniciativa (indiferenciadamente) privada nas atividades educacionais em contraste com generalidade de "nada consta" quanto à pública. É esta suspeita que não vem perfazendo o fulcro do (presumido) problema que a (auto)-avaliação institucional se propõe a dar conta, seguindo práticas administrativo-estratégicas e não recorrendo a suporte metódico de pesquisa qualitativa em coerência com "objeto" também qualitativo de uma educação que se volte para autoafirmação pessoal-desenvolvimentista a se estender a trabalho, produção e sustentação também coletiva.

A propósito da ausência desse "objeto", cumpre admitir que, dentre as concepções sobre assuntos que dizem respeito ao ser humano, certamente que aquela sobre trabalho situa-se entre as mais compreensivas de equívocos, aporias e subterfúgios. Compreende, inclusive, sua própria antítese, de tal forma que, em matéria de sustentação também coletiva, trabalho incide na questão inevitavelmente administrativoinstitucional da falta de soluções como se fosse a própria solução. Entretanto, sentido inequívoco do que seja trabalho, produção e sustentação não tem intrigado, nem mesmo pedagogias críticas a constarem de diretrizes curriculares.

Adentra-se, neste preciso ponto das argumentações levantadas, ao propriamente inaudito da qualidade de pertinência inequivocamente educativa. Evoca-se, para tanto, a eventualidade de se chegar à coincidência entre, de uma parte, alcance inequivocamente universal de referente de qualidade de uma educação universitária a ser avaliada e, de outra parte, conhecimento do alunado plausível de exame, desde que, previamente a este, o modo inequívoco de produzir encontre 
condições de ser objeto de ensino e objetivo de aprendizagem, ambos a mediarem os conteúdos curricularmente definidos. E estas condições teriam que resultar de pesquisa institucionalmente promovida e a preceder ensino e aprendizagem, perfazendo alternativa institucional de procedimentos avaliativos de qualidade de uma educação a ser promovida.

Com efeito, há como vislumbrar que insuficiências e/ou tergiversação a respeito de educação universitária e de produção justifiquem institucionalidade de avaliações em pedagogia e em ciências administrativas no âmbito de IES. Assim, caráter crítico de pedagogia e de ciências administrativas tem sido solicitado a dar conta de prevenir problemas cuja geração se deve à coincidência de que docentes e administradores se alienam a respeito de inequivocação quanto a produzir e, desta forma, somam-se as alienações e cada profissional acaba por levar ainda mais do que aquelas que previamente já possuía. Em síntese, há admissibilidade de que inequivocação quanto a produzir venha a ser objeto de ambas essas áreas de conhecimento.

Da perspectiva do educando e do educador, a coincidirem com administrando e administrador, a única obrigação (conduta pessoal) a ser institucionalmente universalizável seria aquela de produzir de modo inequívoco, ou seja, como questão estritamente mediadora por entre objetos de ensino e objetivos de aprendizagem. Todavia, não há como essa obrigação ser legal-regulamentar (compulsória), porque incidiria em supressão da liberdade humana que é o fundamento real da cidadania e do direito de ir e vir sem ter que incessantemente dar explicações.

Educação universitária de inequívoca qualidade deve coincidir com aquela voltada para cientificar o educando a respeito de (ainda inauditos) desdobramentos de um seu inequívoco produzir em vez das (sobejamente reconhecidas) 
implicações de não o fazer ou da falta de soluções como se fosse a própria solução da sustentação também coletiva. Já esta falta de soluções não se defrontou com (alteridade de) conduta que a previna e cuja procedência justifique educação de menos duvidoso sentido universitário, ou seja, ensino e aprendizagem do discernimento, a toda prova de veracidade, sobre o significado do que seja produzir.

Então, o mero pensar, correspondente a esse significado, será abertura para autoconhecimento, tendo-se em conta que este somente há de incidir em suficiência de atitudes e condutas, à medida que se estatele contra a (até então irreconhecível) custosidade pessoal de produzir de modo, não só inequívoco (custosidade cujo não arrostamento explique, sem que acabe justificada, a existência de sujeição passiva ou ativa a trabalho), como também e sobremaneira, opcional ou real-dinamicamente liberto. (Trata-se de modo cuja ausência explica a falta de soluções prevalecer como se fosse "a" solução do alcance também coletivo da sustentabilidade). Já a própria custosidade há de reportar-se à "gratuidade" de uma proporção das atividades que são imprescindíveis ao atendimento das necessidades natural-humanas também de estranhos.

Ao se defrontar com essa estranheza, o educando adentrará um dilema existencial-real e ainda inevitável nas vigentes condições institucionais: ou terá que ser, paradoxalmente, vítima e cúmplice de algozes na condição de empregado, padecendo geração de "gratuidade", por além do devido inclusive, ou então, virá a competir pelo privilégio de sobreestar como algoz, capacitando-se a impor tal "gratuidade" a outrem, mediante criação de condições para conduzir-se de forma preponderantemente mercenária ou de mover-se tão somente à conta de certeza e ampliação de recompensas. 
Neste último caso, entretanto, cumpre reconhecer que conduta desnaturada e desumana houve de ser seguida, tendo-se em vista que a dinâmica reprodutiva da espécie, sobremaneira por além do coletivo natural-mínimo, sempre implicou proporção involuntariamente gratuita das atividades, ou dos resultados destas, há tanto necessária e "por parte" dos capazes - nunca "por todos", circunstância pela qual a parte, enquanto e apenas tal, explica-se e é justificada em relação à totalidade. Ao contrário de tal conduta, "Gratuidade" e Razão teriam que estar desimpedidas para reciprocamente se afirmarem, apesar de que, para tanto, as oportunidades têm sido usurpadas, à conta da realização da mais-valia que é indissociável de autoentrega à dinâmica do desejo.

A partir da percepção desse tácito e inescapável dilema, o senso de responsabilidade do educando será evocado e este despertará para o que tem sido supérfluo em objetos de ensino e objetivos de aprendizagem, à medida que, em ambos (objetos e objetivos), ele passará a entrever inconfessa tergiversação sobre produzir e subreptícia justificação para apropriar ou alargar propriedades, enquanto conduta de antemão validada e validável. Ficará, então, aberto ao sentido do que lhe há de significar "crítico-teoria", vale dizer, uma espécie de "substrato-chave" para acesso contextualizado ao (auto)-conhecimento, de forma densa e aprofundada.

Chega-se à interpretação dos fundamentos do dilema acima exposto, graças ao discernimento entre produzir e apropriar. E é este discernimento que deverá perfazer inequívoco e universal referente de qualidade do processo educativo em sua totalidade e, circunstancialmente, também elementar, ao permitir que sejam contextualizados os objetos de ensino e os objetivos de aprendizagem. Paralelamente, surgirão oportunidades para pesquisar questões de qualidade, 
peculiarmente aquela a respeito de uma já imprescindível e desalienante educação de adultos inseridos no mundo do trabalho.

Neste ponto da apresentação do argumento em pauta, um crítico contra-argumentaria que o objeto em consideração já estaria superado. Produzir desanda em nada mais do que apropriar, paralelamente ao que sucederia com educar e avaliar, ou seja, formar e institucionalizar privilégios. Com efeito, e por tácito que o esteja, é o que está a ocorrer pelo agigantamento de certa interface entre formalidade e institucionalidade, a desandar em outra interface entre empregabilidade não universalizável e tecno-cientificidade educacional. Todavia, tais interfaces se agigantam tirante a "salto no escuro" (alcance também coletivo da sustentabilidade encontra-se sempre mais prejudicado, o que transparece nas desigualdades políticas, nas disparidades econômicas e nos desníveis de acesso à tecno-ciência, em perspectiva pessoal, regional ou mesmo continental). Este salto traduz tendência que se acentua apenas, há muito pouco tempo, para que suas múltiplas implicações acabem interpretadas à altura do desafio que representam. Nesta perspectiva histórica, cabe ressaltar o que ainda subsiste de real-concretamente fundamental.

Educar, a princípio, não é avaliar. E, de fato, educar faz sentido e perfaz sua própria razão de ser. Nas mesmas condições, educador não é avaliador institucional, porém faz sentido, assim como incide na sua própria razão de ser, ele dedicar o máximo possível de suas energias, talento, tempo e meios, para dar conta de nada mais do que educar. Tudo o que lhe for impingido, dizendo respeito sempre menos direto com inequívoco educar, fica-lhe gradativamente disfuncional, inútil, prejudicial inclusive. Urge, então, arguir que avaliar melhoria de qualidade de uma educação, sobremaneira 
em alcance institucional, vem a ser ocupação privilegiada de impingir, a outrem, estado paradoxal de vítima e de cumplicidade em relação a tal impingimento, além de tacitamente denunciar-se na condição de atividade alienada quanto a produzir até educação. Tem havido alienação a respeito de produzir inequivocamente e tal alienação tenderá a ser estrutural, caso o produzir educação, além de inequívoco, não venha a ser opcionalmente assumido.

Efetivamente, e antes de tudo na perspectiva meramente institucional, avaliar não tem coincidido com educar. Sobremaneira, e sem importar de que forma ou modo, não tem (assim) coincidido com produzir educação de modo também coletivamente sustentável. Todavia, tem subsistido uma larga intercessão entre forma institucional de avaliar e procedimentos administrativos de acompanhamento e controle no âmbito da função de planejamento. E, se esta função se tornou estratégica, isto pouco ou nada tem tido a ver com produção inequívoca, mas com insuficiências de uma produção que, além de inequívoca, viesse a ser opcionalmente empreendida.

Significado estratégico tem incidido, para todos os efeitos, na privilegiada ocupação de impingir a outrem padecimento de atividades parcial-forçosamente gratuitas, inclusive como autoadmitida produção do impingidor que dela se beneficie. Administrar não tem sido produzir. Ao contrário, faz-se imprescindível (institucional, em rigor), porque, em última instância e à conta dos resignados de sempre, produção coerente com sustentação também coletiva não tem ocorrido sem que algozes imponham, a outrem, estado paradoxal de vítima e de cumplicidade em relação a tal impingimento. E é em tal perspectiva que educação houve de ocorrer alienada, estranhada ou alheada, quanto a se (auto)-produzir de modo inequívoco e, por ainda referencial-utópico que o seja, de 
modo também opcionalmente assumido. Assim, a educação se torna propensa a até mesmo se suicidar, inclusive porque, à custa das futuras vítimas, acaba funcional a realimentar a formação dos exploradores.

Reforça-se, então, o caráter alterino do argumento, vale dizer, veracidade qualitativa de uma educação significará que esta evolva, avance ou mude no sentido de se identificar com objeto de ensino e objetivo de aprendizagem, ambos coincidentes com discernimento, a toda prova, do que seja produzir. Contrariamente, ou seja, enquanto ensino persistir alienado em relação a tal coincidência, qualidade educacional persistirá imprecisa, para não dizer, ilusionista, ensejando oportunidade para o seu fundamento real-concreto acabar parasitado por burocracias, ainda que disfarçadas por alcance institucional de avaliações.

A alteridade do argumento em apreço reside na interface entre contextualizar entendimento sobre relações entre inequívoco produzir e mudança educacional, esta na perspectiva de se achegar a conhecimentos, graças à mediação de sentido "crítico-teórico" em que o discernimento em causa há de incidir. Já esse sentido da mediação, por decorrer de abertura ao caráter também coletivo de toda particularidade sustentatória, contrapõe-se a perspectivas pedagógicas escudadas em mera acumulação de narrativas de saberes tidas por conhecimentos, sobremaneira se tal acumulação for estimulada e, por isto, fadada a fomentar soltura de reivindicalismo criador de insustentabilidade coletiva. À conta dessa contraposição, há como avaliação até coincidir com educação, desde que ocorra mediada por inequívoca produção de questionamento reconstrutivo de conhecimentos, ou seja, mediante contextualização de narrativas de saberes em alcance interiorizado, pessoal e/ou sociogeograficamente. Eis, em síntese, o sentido inaudito do argumento! 


\section{Cientificidade da pedagogia - síntese de um problema ainda em aberto}

Eventual cientificidade de uma proposta pedagógica também há de constituir resposta à ameaça de insustentabilidade coletiva à qual se expõe uma IES isolada e interiorizada. Todavia, até a mera busca dessa cientificidade assume significado de humildade e ousadia. Humildade, porque depende de inequívoca produção intelectual. Ousadia, porque esta produção possibilita levantar, ao menos hipótese, quanto à própria cientificidade.

Nas universidades, ou mesmo nos centros universitários, assim como fora do respectivo curso, a pedagogia não assume o "status" sequer de didática transversa. Em seu próprio campo de atuação, outros campos se fazem valer, o que chega a insinuar que ela perfaça uma espécie de vazio, de vacuidade ou de mera nominalidade a servir de endereço para numerosas ciências serem ensinadas. $\mathrm{Na}$ atualidade, ciências comunicacionais e psicológicas estão a esvaziá-la até mesmo da condição de teoria das práticas didáticas, das quais sempre se valeu para deter esta condição.

$\mathrm{Na}$ Antiguidade Clássica, sem perder sua referência à ação de um escravo acompanhante de crianças que se reuniam com outras para memorizarem narrativas poéticas, se iniciarem em leitura, escrita e música, além de praticarem exercícios físicos, a pedagogia esteve prestes a se emancipar como ambiente de acesso e discussão de propostas filosóficas. Entretanto, segundo Kosick (2002, p. 215), para um historiador que separe a solução da problemática, o pensamento filosófico desandou "de dramático cenário da verdade" em "cemitério de categorias mortas". 
Segundo uma referenciada e sintética pesquisa de Saviani (2007a, p. 15-17), a cientificidade da pedagogia ainda representa uma incógnita. Mas, esse pesquisador aponta que o caminho de ela acabar se colocando como ciência é aquele de se ter em vista "a constituição de algo como uma segunda natureza" do homem, a par de que urge chegar ao pertinente estatuto epistemológico, sobre cuja base precisa-se "estruturar o curso correspondente".

Diversamente, caberia "crítico-teorizar" que se trate de estruturação não apenas em alcance endógeno ao curso, pois o que constituiria problema há de residir em a pedagogia deixar de ser um mero departamento no âmbito de uma IES, inclusive no caso de uma faculdade isolada. Se a instituição é educacional, o objeto da pedagogia terá de mediar toda a pertinente composição.

A partir das três considerações acima explicitadas, cumpre ter em conta que a trajetória existencial do "homem" (ente filosófico) tem sido aquela de construir o absurdo do seu próprio fenômeno, cabendo propriamente à pedagogia apontar esta trajetória e, com isto, opor alteridade de via humanoemancipatória. O fulcro desta via será "gratuidade", a ser opcionalmente gerada. Já esta geração incidirá em atuações cujo campo ainda carece de denominação que signifique ir e vir por entre horizontes de ultrapassagem de toda sujeitação a outrem, desde aquela do antigo escravo até a atual do professor movido a soldo. Entretanto, tal "gratuidade" não perfaz nem mesmo problema no atual contexto das ciências da educação. Em desfecho, adentra-se a uma problematização no sentido de fazer com que uma necessidade seja, enfim e ao menos, assumida como tal. É o que cumpre efetivar, no capítulo logo a seguir apresentado. 



\section{Instrumentalização para a busca de veraz qualidade e de precisa cientificidade da educação a promover}

\section{A. A notícia sobre uma situação real-concretamente básica e inarredável}

A princípio, anuncia-se relação entre duas situações da condição já adulta do ser humano: (a) "situação epistêmica" que significa sobre-estar propriedades extrínsecas à pessoa como instrumento de se garantir autossustentação, ilimitadamente; e, (b) "situação hipostêmica" que traduz subestar tais propriedades enquanto condição autossustentatória.

Essa (anunciada) relação tem correspondido a mero vazio de saber e, por isso, este vazio incide na carência de razão para existirem as duas situações. Estas, por sua vez, refletem necessidades de conhecer fontes do que apropriar no exterior da condição adulta do ser humano. Então, o confronto das diferenças correspondentes a tais necessidades também há de perfazer razão de existir aquele vazio com seus não sensoriais objetos.

Existe necessidade de autofundamentação na "situação epistêmica", pois esta tem sido ainda irreconhecível característica da condição do observador que precisa manter e/ou expandir fontes do que apropriar no exterior de si mesmo. Estas fontes têm de ocorrer como especificidades que 
também lhe são exteriores, enquanto ele próprio se encontra em um ponto, dentre incontáveis outros, na totalidade real. Assim, o real-concreto de tal apoio perfaz insignificância, assim como conveniência de restar irreconhecível, uma vez que reproduz a extemporaneidade do apoio da pessoa não mais naturalmente autoinsustentável e cujo pensar acabou alheio à sua original inocência no âmago do coletivo natural-mínimo, que lhe constituíra posse até que esta acabasse substituída por propriedades de objetos extrínsecos a sua própria pessoa.

$\mathrm{Na}$ "situação hipostêmica" existe necessidade de desalienação, pois ela tem sito característica da condição real-concreta, também ainda irreconhecível, de inequívoco produtor que, enquanto tal, não tem tido como observá-la. Trata-se de condição que permanece usurpada, por ser imprescindível ao atendimento da extemporânea autoinsustentabilidade de adultos excessivamente apropriadores. Já esse atendimento presume atividades, e/ou resultados destas, a terem de ocorrer, em crescente parte, no exterior da propriedade da pertinente fonte, ou seja, forçosamente gratuitas.

Cumpre, então, ultrapassar o que permanece ainda irreconhecível e a perfazer ambas aquelas "situações", alcançando-se uma síntese que passe a ser denominada de "ínfero-referencial" (situação alterina à "epistêmica" e à "hipostêmica", ocorrendo por entre assumir opcionalmente gerar "gratuidade", ou então, criar o absurdo da propriedade enquanto matriz de incontavelmente mais problemas do que soluções $\left.{ }^{1}\right)$. Trata-se

1 Conforme Bergamo (2007, p. 139-140). Trata-se de argumento que influenciou a busca de saída para a problemática em que a docência se vê imobilizada por uma espécie de "camisa de força". Só a gratuidade lhe permite mover-se. (Assunto acima já abordado, em II, D). A criação de incontavelmente mais problemas do que soluções será discutida mais à frente (III, B, 1). 
de síntese que tende a coincidir com "situação diastêmica", básica e inarredável, e que teria sido buscada por Sócrates ${ }^{2}$.

Absurdo criado vem a ser uma sociabilidade eivada de injustificações, ou seja, plena de desigualdades políticas, disparidades econômicas e desníveis de acesso à tecno-ciência, as quais têm ocorrido entre si inseparáveis. Sintoma elucidativo dessa sociabilidade reside em se ter que sempre mais "pagar para produzir", em vez do que é divinamente natural ou naturalmente divino, ou seja, obter resultados, os melhores e mais amplamente possíveis, compensando o esforço de intercambiar com a natureza, direta e organicamente.

Por sua vez, a opcional geração da "gratuidade" ainda permanece represada, ou seja, resta apenas tencional e potencial. Esta geração se explica e é justificada na relação entre pessoa e coletividade, à medida que esta última, ao contrário da primeira, caracteriza-se por não se constituir nem se manter por si mesma, mas ambas, e concomitantemente, são imprescindíveis à reprodução da espécie. Não há como subsistir suficiência de coletividade, sem um excesso de atividades e/ou de resultados destas, excesso este a ocorrer, necessária e ainda insuficientemente, fora da propriedade particular-pessoal. Tal ocorrência há de constituir antídoto à fonte do desejo de acumular propriedades, fonte que, de forma recorrente e predizível, há de renascer, como o mito da "fênix", das cinzas das revoluções contra a mera objetividade do alcance privado da propriedade.

Em síntese, "ínfero-referencial” há de sugerir alteridade de relações humanas, cujo paradigma resida nos teores da relação entre prole ainda autoinsustentável e quem, direta ou

2 Segundo Aristóteles (1984, p. 24), apenas Sócrates abordara "coisas morais, e de nenhum modo do conjunto da natureza", abrindo caminho para Platão o fazer em "outras realidades e não nalguns sensíveis". 
indiretamente, a sustenta. Com efeito, esses teores perfazem relações interpessoais, cuja extrapolação para reais-concretos mais complexos tem sido abortada por falta de mediação pedagogicamente dialética entre "posse e despossessão do coletivo natural-mínimo".

Assim, cabe ao menos hipotetizar que o objeto da pedagogia tem sido uma omissão - um vazio, uma vacuidade ou um abismo. Por sua vez, a condição desse objeto faculta-lhe acabar preenchido, ocupado e colonizado por ideologias, a partir daquelas a respeito de processos humanizadores. Alterinamente, presença de mediação pedagogicamente dialética há de significar objeto preventivo de vitimação a ideologizações, a começar pelo recurso metódico a uma especificidade dialética que perfaça radical real-concretude humanizadora. Porém, antes de recorrer a essa especificidade dialética, cumpre apresentar os fundamentos aos quais foi possível chegar, à conta das considerações até este ponto desenvolvidas a respeito do ensino superior, à base da pertinente prática social, assim como da problematização quanto à qualidade e à cientificidade de tal ensino.

\section{B. "Historização" enquanto "paradigma da insustentabilidade coletiva"}

\section{Absurdidade em construção}

A história, enquanto processo propriamente cultural-civilizatório, desdobra-se em dois mais peculiares e continuados desfechos que têm sido, insistentemente, referenciados por oriental e ocidental. É-lhes comum, todavia, uma cultura a se autoequivocar sobre o que seja produzir, autoequivocação que lhes perfaz um "substrato-chave" mais visível nos contrafortes das estáveis instituições extremo-orientais, porém 
recorrentemente escondido nos bastidores das inconstantes organizações ocidentais. Estas, por sua vez, são assumidas tais como acabaram interpretadas pelo sociólogo Max Weber (1983, 1-15), na introdução de sua ainda inconteste tese sobre alternativa de espírito capitalista. Resta implícito que, sopesadas as correspondentes ideologias, as instituições ocidentais têm assumido um vezo antes agressor do que defensor da imprescindibilidade de um produzir nunca diferenciado de apropriar, o que (ainda) lhes faculta se beneficiarem de uma alegada superioridade de processo cultural-civilizatório.

No Oriente, o que se caracteriza como propriamente institucional tem a ver com a imprescindibilidade de produzir em reciprocidade de coerência com intercâmbio orgânico com a natureza - livre e humana - e com a defesa das condições de prevalecer conformidade com o caráter assim imprescindível de a produção se realizar.

No Ocidente, institucionalidade tem sido resposta socialmente superestruturada por força de um problema culturalmente recriado e bem determinado, o qual diz respeito à inarredável e escondida interessença que motiva a conquista e a preservação do poder. Trata-se de interessença que se traduz na imprescindibilidade artificial-cultural de garantir, a todo custo e previamente, o atendimento das necessidades básicas, inclusas aquelas da espécie, as quais, em si mesmas e a rigor, têm sido avalores, ou mesmo antivalores. A rigor, o que acaba valorado é o pertinente atendimento, em si mesmo, bem como na imediata e mais adequada prontidão dos requeridos meios. Todavia, tal valoração vem acontecendo de forma peculiarmente apropriativa do "intercâmbio material-comunicativo" entre pessoas, entre estas e as organizações e entre as próprias organizações. Por sua vez, essa forma apropriativa vem ocorrendo à conta de autoequivocação, quanto a produzir, devida 
a pessoas e prepostos das organizações. Já aquele intercâmbio, apesar de imprescindível à expansão da produtividade, sempre se encontrou inserido em uma cultura negadora da "gratuidade" da perspectiva de quem a gera, a começar por aquela da natureza livre e, cabalmente, também da humana.

Cumpre, então e ao menos, hipotetizar sobre três fundamentos dessa cultura peculiarmente ocidental: (a) ao negar a natural "gratuidade" humana, os seguidores dessa cultura desvelam seu vezo inercialmente reprodutivo da "posse do coletivo natural-mínimo", o que tem ocorrido por além do período de natural autoinsustentabilidade da pessoa que, na espontaneidade dessa posse, conta com outrem para se sustentar, sob pena de este outrem, alternativamente, sequer ter como subsistir; (b) ao longo da história individual e desavisadamente, equivocar-se quanto a produzir vem desandando em um esfalfar-se racional-operativo, pelo qual se busca compensar, à base de propriedades exteriores à própria pessoa, a perda do originário vínculo de parentesco; e, (c) ao contrário do que se presume como algo imemorialmente ocorrido no passado da espécie humana, "o primeiro ato histórico do homem"3 sempre houve de coincidir com aquele de negar, sem disto sequer se dar conta e na história de cada uma e de todas as pessoas, a "gratuidade" que é inerente à natureza livre

3 A expressão "o primeiro ato histórico" do homem foi suprimida por Marx e Engels do manuscrito sobre a "Crítica à Ideologia Alemã", ao longo da revisão para efeito de vir a ser publicado. Todavia, foram apresentadas, segundo Manacorda $(2007,61)$ "não sem certa ironia", circunstâncias - o quanto possível verossímeis, conforme se presume - em que esse ato poderia ter acontecido, para que se coadunassem com certas posturas dos ideólogos alemães, os futuros e mais prováveis leitores. Nesta perspectiva, ao mesmo tempo irônica e verossímil, cabem ser examinadas aquelas circunstâncias, ao se ter em vista estabelecer distinção entre indivíduos humanos e espécimes animais. É que, segundo a denominação proscrita, o que caracterizaria o alcance humano desses indivíduos "não é o (ato) de pensarem, mas o de começarem a produzir os seus meios de vida". 
e às próprias pessoas, criando-se, por uma parte, escassez de espaço vital, inclusive para o poder coincidente com tal negação e, de outra parte, a necessidade cultural de a obtenção de meios de atender as outras e naturais necessidades ser reduzida ao secreto significado de servir tão somente de pedestal aos poderosos.

A “criação de escassez" de espaço vital tem coincidido com uma sociabilidade cujo fulcro vem sendo a interdependência entre o próprio criador e quem, inequivocamente, o sustenta. Trata-se de fenômeno que usurpa o sentido do coletivo natural-mínimo, substituindo-o por relações sociais a se desvelarem peculiarmente em ambiência citadina. Por sua vez, essas relações se processam de modo sincrônico-topocêntrico, tirante à circunstância que faculta conceituar espaço em física, vale dizer, não houvesse efetivos ou potenciais choques entre unidades de matéria, tal conceituação seria impensável.

O método seguido pela "criação de escassez" de espaço vital coincide com a dinâmica que é própria do açambarcar o que é imprescindível ao atendimento das necessidades básicas, ou seja, das fontes dos meios de vida. A ambiência citadina se "historiza" à base desse açambarcamento, porque dela são projetados tentáculos que servem para impingir e carrear excedentes gratuitamente gerados pela natureza livre, sem que, a esta, seja devolvido um equivalente para sua autorreprodução. À medida que esses excedentes acabem escassos, torna-se necessário promovê-los mediante direta interação com as correspondentes fontes naturais. Para tanto, e até a Revolução Industrial, recorreu-se à exploração da fonte humana de trabalho e, a seguir, à acentuada instrumentalização desta fonte que, por seu turno, vê agigantarem-se as circunstâncias em que ela se torna dispensável, de sobra ou em demasia, porque (inconfessadamente) reduzida a estrito e 
descartável meio de produção. Trata-se de tendência sistêmica e que se processa à base de um impingido reducionismo. É no complicado bojo desse processo que acabam depredados os ainda irreconhecíveis potenciais de "gratuidade" de fonte humana e a efetiva "gratuidade" da natureza livre. Para tanto, ambas - a efetiva e as potenciais - acabam subsumidas sob a ideologia de uma produtividade que, a princípio, seria ilimitadamente intensificável e abrangente.

No alcance sistêmico dessa tendência, impingir geração de excedentes de produção fora da propriedade das respectivas fontes tem sido objetivo ocultamente efetivado e/ou desejado. Uma vez efetivado, este objetivo se concretiza como propriedades exteriores às pessoas dos próprios impingidores. Se desejado, implica em existência imaterial de pertinentes objetos, imaterialidade que há de incidir em infinitude para corresponder à ilimitação que é própria da autoentrega humana à incontinência apropriativa.

Essa imaterialidade sempre deteve "modo de existir "privacional"” (vazio, vacual e não sensorial). Já as propriedades, enquanto reais-concretos perceptíveis, têm "modo de existir "presencial"' (plenista, material e sensorial), caracterizando-se por subsistirem inclusivas de um ou poucos detentores efetivos e excludentes de todos os detentores potenciais que, por isso mesmo, se expõem a tão somente desejá-las.

Ao longo da "historização" da ambiência urbana, desde os refúgios mais primitivos até chegar às metrópoles modernas, a apropriação tem desandado na propriedade e a proliferação desta em incontavelmente mais problemas do que soluções. Tal evolver cultural-civilizatório tem como ser aquilatado, inclusive à base de ciências positivas. Para tanto, há como entender por solução o mero e direto dispor de meios de vida, interagindo tão somente com a natureza livre, apesar de esta 
interação, à conta de requerido desconforto, ter sido, de modo recorrente e predizível, o mais significativo dos problemas em questão. Por sua vez, problema acaba definível também pela necessidade de acessar utilidades no âmbito de propriedades alheias, implicando contratos, além de defesa contra a realização de incontidos desejos de açambarcadores. Assim, haveria tantas soluções quantas fossem as propriedades, mesmo que a proliferação destas acabe por reduzir a possibilidade de constituírem soluções. Entretanto, hão de existir tantos problemas quantos forem as providências defensivas e os contratos para acessar propriedades contíguas e, sobretudo, interpostas entre a própria e as demais. Então, duas propriedades implicariam duas soluções e possivelmente dois problemas. Três delas, significariam três soluções e meia dúzia de possíveis problemas, à conta de que os três precisariam acessar as propriedades de outros dois. A seguir, doze ou vinte possíveis problemas presumiriam quatro ou cinco propriedades, respectivamente. A onipresença da propriedade exigiu o "intercâmbio materialcomunicativo". Mas, até mesmo este intercâmbio e, a seguir, a funcional mediação do dinheiro, ambos acabaram também apropriados. Com isto, passou a ser demandado que a científico-tecnologia dê conta da incomensurabilidade e da complicação dos problemas. Cabalmente, até mesmo a científico-tecnologia está a ser apropriada, perfazendo um desafio que faz o gênio humano adentrar uma fronteira em suas potencialidades.

$\mathrm{Na}$ atualidade, a cibernética, imbricada em instrumentos produtivos, tende a ser tida como promessa de soluções. Entretanto, ela ocorre concebida de forma alheia às implicações da dinâmica apropriativa, o que não a isenta de ilusionismo. 
Trata-se de apontar como as relações sociais, a começar por aquelas de produção, perfazem circunstâncias em que as pessoas têm de sobrar, vale dizer, sentirem-se descartáveis ou constantemente ameaçadas de violência, desde a competitiva até aquela da iminência de exclusão.

O fulcro da análise a ser feita reside no preterir (marginalizar, informalizar e sócio-subjetivar) a relevância humano-científica da obtenção e da destinação dos excedentes que sustentam a reprodução da espécie e das condições objetivas de o próprio coletivo se realizar. Tais excedentes passam a ter que competir com o mero custeio da imprescindível participação no processo produtivo. Já esta participação, por se encontrar exposta à dinâmica apropriativa, tem sido excludente critério de acesso aos resultados desse mesmo processo. Assim, para abordar o fulcro em apreço, cabe recorrer ao método do qual Marx (2003, 246-258) se valeu para analisar a economia política de seu contexto histórico, restringindo-se a análise, entretanto, ao real-concreto da formação dos preços finais dos bens e serviços. Nesta formação, chega-se a apenas duas categorias simples: (a) o que é vendido sem ter sido comprado - mais-valia definida por Marx em "O Capital” (1984, p. 246), diversamente da conceituação contida em "Salário, preço e lucro" (1983, p. 62-65); e, (b) o que é comprado e também vendido, ou seja, custos aquilatados à base de preços que, por sua vez, compreendem outros, em uma cadeia retroativa, cujo ponto de partida é a remuneração de estrita propriedade, cabalmente aquela de direitos sobre resultados da produção, os quais perfazem itens dessa mesma mais-valia.

Os prepostos mais decisivos para a (re)-produção desse real-concreto são aqueles que operam nos labirintos do Estado e do Mercado. Nos labirintos do Estado, vendem-se tributos e naqueles do Mercado retornos privados (líquidos de 
tributos), ambos - tributos e retornos - sem terem sido previamente comprados. Entretanto, desde a captura do Estado pela revolução burguesa, tem acontecido que a expansão dos tributos dependa da perspectiva de expansão dos retornos privados (líquidos de tributos), o que traduz uma espécie de "pacto tácito e, às avessas, entre menos desiguais" (às avessas, porque, até a sustentabilidade da competição e dos conflitos entre os dois partícipes há de resultar em vantagens adicionais para ambos e, à margem, ônus para as fontes de excedentes gerados de forma forçosamente gratuita). Inserção dessas e de outras vantagens e ônus, nos preços dos meios de trabalho, implica em estratégia sistematicamente efetiva para condicionar a destinação das remunerações pessoais, na perspectiva de os beneficiários destas remunerações terem de pagar, sempre mais, para tão só produzirem. Paralelamente, desalienação dos trabalhadores tem desandado em luta contra a exploração deles próprios. Trabalhadores improdutivos também se valem dessa luta para preservarem e/ou expandirem poder aquisitivo das próprias remunerações. Além destes últimos, chegam a emergir nada mais do que lutadores a reivindicarem remunerações cuja contrapartida em termos de responsabilidades tende a se restringir a meras mobilizações sociais em defesa dos próprios direitos. Ao final, desalienação tende a se caracterizar como questionamento da propriedade em si mesma, mas, paradoxal e acentuadamente, volta-se para recriá-la sob a forma de novos direitos sobre os resultados da produção. Ora, nada resulta mais custosamente conflituoso do que a prática de questionamento e de recriação de direitos, urgindo, então, estimular retornos privados para expandir tributos, o que demanda acréscimos na produtividade física (pressão por avanços científico-tecnológicos) e inchaço do trabalho improdutivo (aumento das contraprestações). Cabalmente, o atendimento dessa demanda realimenta a tendência em alcance propriamente sistêmico. 
Em síntese ou em um sempre mais visível desfecho, os excedentes para a reprodução da espécie tendem a acabar competindo com o custeamento privado de participar do processo produtivo, o que passa a ocorrer em "soma zero" (o aumento desse custeamento há de coincidir com diminuição daqueles excedentes ou vice-versa). Em desfecho, tende a se consumar a absurdidade, ou seja, a situação em que os seres humanos se encontrem de sobra, supérfluos ou descartáveis. A escassez de espaço vital favorece a busca de ilusões e impede que estas sejam abandonadas, recorrendo-se ao fetiche da igualdade de oportunidades para consolidar fé profana na tríade constituída por política, epistemologia e economia como inescapável matriz das ciências que passam a substituir o império e o capital na função de explicar e perpetuar as injustificações. Em contraponto, desalienação a respeito dessa fé tende a ser acentuadamente disfuncional ao pacto tácito entre Estado \& Mercado enquanto esconderijo da interessença dos apropriadores do sentido do "intercâmbio material-comunicativo".

\section{Perspectiva de "crise da historização" e seus dois horizontes mais visíveis}

A positividade científica da análise e da síntese, logo acima apresentadas, faculta anunciar uma "crise da historização" que vem sendo endógena aos cinzentos bastidores do processo cultural-civilizatório do Ocidente e em vias de se tornar global.

Essa "historização" tem enveredado por recorrentes e previsíveis descaminhos, dada a circunstância de se resumir ao acúmulo de eventos que decorrem de o ser humano precisar fazer guerra contra tudo, para não guerrear contra si mesmo ou contra a sua própria interessença, ainda que esta e ele próprio se evidenciem demolidores do sentido também coletivo da sustentabilidade. 
Reorientações em tais descaminhos têm ocorrido, em largos traços históricos e em concomitância com mudanças coletivo-sustentatórias a derivarem de "intercâmbio material-comunicativo". Presume-se que este intercâmbio foi deflagrado no Oriente Médio e ao longo das costas do Mediterâneo Oriental (territórios que evocam os nomes de Suméria, Babilônia, Egito, Fenícia, Creta, Anatólia, Hélade, Magna Grécia e Cartago). Em peculiar momento da afirmação histórica de tal intercâmbio, então sob ameaça de acabar contido por prepostos do Império Persa nos séculos $\mathrm{V}$ e IV a.C., houve notório avanço na concepção de constituições democráticas, o que facultou uma mais complexa convivência humana em cidades-Estado. Foi, também em tal momento, que emergiu a Filosofia, assim como avanços em tecnociência, a exemplo daqueles em instrumentos bélicos e em navegação marítima. Mas, a ideologia imperial acabou por prevalecer também naquelas cidades, tendo, por "vazo comunicante", o que está referenciado em Williams (2000, 47-53) como "lacuna metafísica" em Platão e que cabe atribuir também à Política em Aristóteles ${ }^{4}$ e à apropriação da mensagem de Jesus de Nazaré, inicialmente por helenistas tardios e, a seguir, por políticos devotados à preservação do Império Romano ${ }^{5}$. Todavia, em medievais ambiências monásticas, já isoladas em relação à ideologia profano-imperial, tornou-se

4 Em sua obra intitulada Política, Aristóteles $(2007,145)$ declara que, assim como o todo é superior às partes, um homem extraordinariamente virtuoso deve ser governante vitalício, indo ao encontro da convicção desse filósofo quanto à monarquia coincidir com a melhor forma de governo.

5 Para Russel (1982. II, 34), “o Estado (a corte imperial romana) era fraco, incompetente, governado por homens sem princípio, que procuravam defender apenas seus próprios interesses, sem qualquer política que fosse além de expedientes do momento", ao contrário do que ocorria na Igreja que era dirigida por homens "prontos para sacrificar tudo no interesse dela" e, por isso, veio a ser vitoriosa ao longo de todo um milênio subsequente. 
enfim possível conciliar riqueza com até mesmo ascese de inspiração religiosa que, apriormente, sempre a rejeitara:

O paradoxo de todo ascetismo racional, que de forma idêntica fez tropeçar os monges de todas as épocas, está em que o próprio ascetismo racional criou a riqueza mesma que rejeitava (Weber, 1982, p. 380-381).

Anteriormente a essa observação de Weber, Marx já apreciara mudanças materiais possibilitadas, em seu entender, pelo capitalismo de seu tempo. Entretanto, em uma espécie de gesto mecânico, subsumido à sua (desde então até necessária) anatemização da mercadoria, o mesmo Marx jogaria fora com a "sujeira da água do primeiro banho" o renascimento do "intercâmbio material-comunicativo" junto com o avanço da modernidade, gesto que Habermas relativizou, porém não resolveu, ao eleger-lhe o alcance comunicativo e, à conta de redução a instrumental, ao preterir-lhe a materialidade.

Essa atitude de Habermas teria como compor resposta a uma crise na apropriação da base material-planetária do intercâmbio, nos bastidores das Guerras Mundiais, do Holocausto e do bombardeio de Hiroshima e Nagasaki. Por hipotético que tal ajuizamento ainda precise ser assumido, cumpre explicitá-lo à luz de certa repetição, no advento e no avanço da modernidade, do que ocorreu ao longo do ocaso da Antiguidade Clássica. Trata-se de ajuizamento que cabe ao saber acadêmico pesquisar-lhe a fundamentalidade e o assumir, desde que se tornaram inusitadamente conservadoras as circunstâncias em que emergiram o pós-modernismo, o pósestruturalismo e o pós-industrialismo nos atuais horizontes da cultura e da civilização. Além disso, urge que esse saber se reconheça ainda insuficiente para prevenir as injustificações que hão de conduzir a novos descaminhos. 
Em tal perspectiva, resta ao menos admissível que crise ainda detenha significado analógico àquele que remonta à medicina de Hipócrates (460-377 a.C) e que "indicava a transformação decisiva que ocorre no ponto culminante de uma doença e orienta seu curso em sentido favorável ou não" (ABBAGNANO, 2007, p. 259). Esse sentido analógico de crise tem respondido ao alcance miticamente estável das instituições, ou seja, à crença na ausência "de conflitos políticos e sociais insolúveis, de lutas ideológicas, de antagonismos filosóficos e religiosos, a testemunharem a fundamental incerteza ou ambiguidade dos valores da época" (p. 259).

Em desfecho de sua (assim admissível) crise, a "historização" há de se bifurcar em dois horizontes cabalmente mais visíveis: (a) continuidade da extemporânea "posse do coletivo" na esfera da subjetividade, ou seja, na permanência de autoentrega à absurdidade em construção que, por sua vez, também continuará a ser objetivada enquanto artifício a decorrer do seguimento da racionalidade moderna; é seguimento que tem sido alheio ao discernimento entre apropriar e produzir, apesar de este mesmo discernimento adentrar uma espécie de promessa de reverter o vezo fragmentarista do conhecimento, vezo que foi deflagrado pelo enciclopedismo e que se encontra em vias de ser globalizado pela (residual-imperial) insistência de transformar em hegemônicas, para não dizer excludentes, as regras cientificizantes do método; e, (b) admissibilidade de que haja "despossessão do coletivo", na perspectiva da "historicização" da práxis de anuir, em alcance propriamente transpessoal, ao sentido da flexível vital-fertilidade do produzir inequívoco e opcionalmente empreendido - é o que cumpre desde já denominar como "humanização 'crítico-teórica”, vislumbrando-se ultrapassar, em alcance genuinamente acadêmico, insuficiência crítica de teorias em geral. 
Neste horizonte de "historicização", cumpre questionar as circunstâncias vigentes, mediante proposição de alteridade de saída ao menos no âmbito das humanidades. Trata-se de saída pela qual a referência marxista do modo de produção há de acabar substituída por inequivocação quanto a produzir, por aquém do que vem sendo proposto à base de correção do discurso político e de radicalidade normativa. (Tal alteridade de saída tem a ver com questões ainda inadmissíveis cujas sínteses são apresentadas logo a seguir).

\section{Questões alternativamente inadmissíveis}

Subsistem (não escassos) reais-concretos que ainda não têm tido oportunidade de se tornarem fundamento de correspondentes objetos de saber. Nesta altura das questões que devem preceder à abordagem da especificidade dialética, cumpre ter em vista, dentre esses reais-concretos, os três tópicos que se seguem.

Em primeiro e principal plano, emerge a questão de que o significado do que seja propriamente produzir tenha como ser inferível, à base da "relação entre prole e quem, direta ou indiretamente, a sustenta". O real-concreto a que corresponde essa relação sempre houve de coincidir com a sustentabilidade do coletivo natural-mínimo, assim como de perfazer uma referência de (ainda potencial) "historicização", cujo substrato-chave há de incidir em despossessão, ético-educacionalmente mediada, de coletivos progressivamente mais complexos. A dialética dessa despossessão adentraria radicalidade, por incidir em inalienável "real-concreto humanizador" e, por isso, seria também antisseletivista. Ademais, cumpre admitir que a reprodução de elites tem sido radicalmente incompatível com democracia. E, mesmo que 
se tratasse de uma elite acatada como virtuosa, ela teria que se caracterizar por assumir reciprocidade de coerência com essa mesma incompatibilidade.

Racionalidade com relação a fins e a valores é outra das questões em apreço, pela circunstância de se restringir apenas a processos e a pertinentes desfechos. É que essa racionalidade não se volta para sequer a eventualidade de lhe subsistirem pontos cegos ou costas, cuja percepção e interpretação incidam no desvelar-se da razão a si mesma. Há sintomas dessa incidência, dentre os quais destacam-se duas subquestões: (a) aquela da "situação epistêmica", acima já descrita e sumariável como sobrepor-se a diferenças como se fossem identidades (especificidade disto ou daquilo não deixa de incidir na diferença que é própria de uma totalidade), ou então, calar sobre diferenças pertinentes a resultados que presumem funções; e, (b) "criação de escassez", igualmente já exposta e sintetizável como imperceptível acumulação de objetos de desejo ainda irrealizado ou irrealizável, a ocorrer em alcance sincrônicotopocêntrico, ou seja, como matriz de contraditórios aos quais correspondem contradições.

E, já adentrando o limiar de especificidade dialética, há a questão pouco ou nada acessível à própria reflexão e que precisa vir referenciada por "identidade a toda prova". Trata-se da identidade que só é própria à imaterial infinitude em que resulta a imperceptível acumulação de objetos de desejos irrealizáveis ou a ainda serem realizados, vale dizer, ao "modo de existir "privacional"” de tal acumulação, ao qual se chega por força do inescapável ponto de partida da produção intelectual. Tal identidade - primordial produto em dialética - perfaz requisito para a fundamentação do método e da formalidade lógica. Por força de tal princípio ou ponto de partida, é este modo de existir que, em oposição àquele perceptível 
da propriedade, permite deflagrar a determinação da especificidade dialética, ou seja, a fundamentalidade de toda a investigação ora em processo.

\section{Especificidade dialética}

\section{1. "Forma por entre opostos" inerente ao real- concreto da dinâmica do desejo}

Não tem feito sentido algum "o homem" nascer e viver tendo necessidades, sobremaneira as básicas e as da própria espécie, de tal forma que ser livre coincide com o atendimento da (anteriormente mencionada) necessidade histórico-culturalmente criada de avalorar ou mesmo antivalorar o alcance vital-básico de certas necessidades. Esse atendimento significa prevenir inserção em relações de produção, as quais guardem reciprocidade de coerência com intercâmbio orgânico com a natureza. Adentra-se, então, à socrático-platônica dinâmica do desejo, cujo real-concreto se processa dialeticamente. Tal adentramento é logo a seguir apresentado, à base de concepções do que há de perfazer essa dinâmica.

De início, concebe-se um "miolo" de uma totalidade, o qual perfaz, realisticamente, uma forma de existir por entre dois modos. Um destes modos é epistemicamente perceptível, enquanto o outro é ocultamente fenomênico. Ambos se opõem, à base dessa mesma forma e enquanto inescapáveis componentes da própria dinâmica do desejo. Há, então, a condição "presencial" da propriedade - esta, enquanto objetos perceptíveis ou materialmente aparenciais. Trata-se de condição que desperta os sentidos e faz repousar o desejo. Também há a condição "privacional" da falta de objetos, falta esta a incidir em necessidade criada que, de per si, é imperceptível 
e imaterial. Por sua vez, esta condição contém e delimita os sentidos, o que atiça o desejo a ponto de revesti-lo de ansiedade. Então, aquela forma tem como ser inferida em alcance tão existencial quanto ambos esses modos. Assim, a totalidade percepção-inferência-interpretação incide em efetiva produção cultural, inclusive em horizontes da síntese dos opostos na proposta marxiana de inverter a anterior concepção idealista da dialética em Hegel.

Com efeito, à luz da história filosófica das conceituações da dialética em Abbagnano (2007, p. 315-22), chega-se a tal forma de existir, contando-se com procedimentos cuja aplicabilidade serve de apoio para avançar na busca de qualidade em produção cultural. Para tanto, emergem três momentos: (a) coloca-se algo "abstrato e limitado" (aponta-se uma tese, a exemplo daquela de que, na modernidade, "espírito do capitalismo" seja significativo teor do "assunto socrático-platônico" que é pertinente à dinâmica do desejo e, enquanto tal, perfaz objeto abstrato-intelectualmente disputacional ou erístico); trata-se da ilimitável imaterialidade da "escassez criada" a se fundamentar na oposição à limitada realidade da propriedade; (b) suprima-se essa limitada realidade - a propriedade - e haverá inserção em determinado oposto (antítese); trata-se da inserção na estritamente imaterial existencialidade da "escassez criada" (inserção à qual os despossuídos têm tido que se sujeitar desde tempos imemoriais e que precisaria ser vivenciada pelos capitalistas após a marxiana despossessão das fontes objetivas dos meios de vida); e, (c) resulta, daquele fundamentar-se na oposição e desta inserção na antítese, que a imaterial realidade (dos objetos de desejos irrealizáveis ou ainda não realizados) tem tido, por si mesma, como coincidir com a "situação epistêmica", esta enquanto circunstância em que é facultado perceber-inferir-interpretar tudo o que apraz a um apropriador; por isso, a "situação diastêmica" há 
de coincidir com aquela que é imprescindível para se chegar a autoconhecimento (síntese dos opostos, inferencialmente por entre modos de existir e como qualidade na produção cultural de determinado "real-concreto a se humanizar").

Contando-se com apoio assim inferencial, torna-se possível ao menos aventar uma "forma de existir por entre opostos" que subsista tão radicalmente real-concreta quanto o fazem o "modo de existir "presencial"" e o "modo de existir "privacional", além de os três - ambos os modos e aquela forma - serem inseparáveis por inteirarem um todo abstrato-representado que corresponde a um único real-concreto. Porém, a forma se tornará assim (auto)-inferencial tão somente na "situação diastêmica" (na interioridade desse todo). Em sua realidade, trata-se de forma a refletir co-fundamento de um real-concreto e a se inferir tão somente na sua coincidência com este mesmo co-fundamento.

À base desse todo assim abstrato-representado, autoconhecimento há de coincidir com despossessão de coletivos, ou seja, inverte-se a condição da sustentação individual, antes provinda do coletivo natural-mínimo e, desde agora, tendo que ser entendida como imprescindível, além de procedente tão só da pessoa, da parte ou do componente do coletivo. Trata-se de inversão que só ocorre mediada por inequivocação quanto a produzir autoconhecimento, mesmo que este produzir tenha que fazer sua história à margem dos vigentes modos de produção que, por seu turno, se caracterizam por subsistir inseridos na ainda inescapável dinâmica do desejo. Ademais, produzir é prática carente de reflexão por implicar limites ao apropriar exteriormente às partes e, por reciprocidade de coerência, interiormente a esta ou àquela totalidade.

A forma assim situada há de incidir na própria dialética como qualidade procedimental, instaurando-se uma tríade 
metódica que se constitui de: (a) constatação - à conta dos sentidos, inclusive mediante instrumentos - do "modo de existir "presencial"" dos reais-concretos que são abstraídos no processo de conhecimento (fundamentos, realistamente delimitados, que são percebidos e interpretados a partir do miolo da totalidade correspondente à dinâmica do desejo); (b) interpretação do "modo de existir "privacional" por coincidir com ilimitável e real imaterialidade, externamente à propriedade e essencializando o vazio correspondente aos objetos de desejo ainda não realizado e/ou irrealizável; e, (c) "diastemia" como "situação-limite" (fim-começo ou começo-fim), na qual ocorre "incontinuidade-contato" por entre representações correspondentes ao alcance "presencial" e ao alcance "privacional" de um e outro daqueles modos de existir.

Chega-se, assim, à (auto)-inferência da forma enquanto compatível com gnoseogenia, a ser explicitada nos seguintes termos:

"Forma de existir por entre opostos" é aquela que incide em "incontinuidade-contato" por entre dois modos de existir que são entre si cabalmente irredutíveis e que correspondem, de uma perspectiva, ao "presencial" (aquele que desperta os sentidos de quem observa e faz repousar-lhe o desejo) e, de outra, ao "privacional" (aquele que anula os sentidos e atiça o desejo). "Incontinuidade-contato" coincide, em alcance conceitual, com a condição de fim-começo ou começo-fim das delimitações, quer externamente ao (modo de existir) "presencial", quer internamente ao "privacional". Essa coincidência vem a ser "nascimento-morte ou morte-nascimento" dos (entre si irredutíveis) opostos e se traduz na especificidade da forma que, por isto, se desvela tão concretamente real quanto os próprios opostos e, ao mesmo tempo e lugar, coincide com ultrapassagem do contraditório. 


\section{2. "Forma mediativo-configurativa" por entre os sentidos da exurgência das necessidades vital-básicas e do mover-se das funções que as atendem}

Dispondo da conceituação referente à "forma de existir por entre opostos", há como admitir que o "modo de existir "privacional"" esteja a usurpar a cognoscibilidade da condição "ausencial" como ocorre a teleconvergência entre os sentidos do exsurgir das necessidades vital-básicas, inclusas as de reprodução da espécie, e do mover-se das funções que se voltam para atendê-las.

Com efeito, houve de acabar presumido, ou mesmo subsumido, que essa teleconvergência adentre uma tal insignificância que sequer perfaça objeto de estudo. É que o modo de ser das necessidades, por si mesmas, não é diretamente cognoscível (não é objeto imediato de percepção e abstração), o que, entretanto, não impede que se admita sentido, contrário àquele das necessidades, ao modo de ser das funções, também por si mesmas. Assim, por conta desta contrariedade e de que o atendimento das necessidades vital-básicas tem de provir do exterior e se destinar ao interior da pessoa, resta supérfluo ser incognoscível a teleconvergência dos sentidos de ambos esses modos de ser.

As cruciais e entre si irredutíveis realidades dos sentidos de ambos esses modos de ser têm efetivamente teleconvergido, o que faculta inferir "incontinuidade-contato" por entre uma e outra das realidades em questão. Para tanto, incide-se em três momentos: (a) há o sentido do exsurgir das necessidades, o qual, não só procede do interior para a aparência ou para a exterioridade da pessoa, como também coincide com o inevitável e contínuo esvaecer-se das energias, tanto 
conjunturalmente (origem da fome, por exemplo), quanto estruturalmente (origem do envelhecimento); (b) há o sentido do projetar-se das funções, o qual advém do exterior e se orienta para a interioridade da pessoa, coincidindo com o atendimento das necessidades, desde as básicas e as da espécie, até aquelas que derivam das anteriores e que emergem em reciprocidade de coerência com intercâmbio orgânico com a natureza; e, (c) há "incontinuidade-contato" por entre ambos esses sentidos, a qual intervém, como "forma de ser "interflexa", e o faz à base de reciprocidade de pertinência para explicar e de coerência para justificar a individualidade humana, em alcance complexamente relacional entre a pessoa e o coletivo.

Por sua vez, tal reciprocidade faculta intuir o significado do que deva perfazer "razão dialética" que, então, há de coincidir com "situação interflexa" da forma de ser da "incontinuidade-contato" por entre sentidos que guardam reciprocidade de coerência e de pertinência quanto à relação entre coletividade e singularidade humanas. Assim, "incontinuidade-contato" por entre diferenças, por entre identidades, ou ainda por entre uma(s) e outra(s), coincide com o vértice que é interflexo à individualidade e no qual começam e terminam, ou vice-versa, o sentido de uma comunhão de necessidades a se impor como atratividade do que as atende (congraçamento, sociabilidade) e o sentido de uma conexão de funções que correspondem a tal imposição (ética, responsabilidade). Esse vértice se evidencia por entre o que é necessário e o que é funcional, possibilitando integridade da individuação da pessoa e da coletividade, ambas a se objetivarem como realizações. 


\section{Avanço coerente com a história da dialética por entre opostos}

A complicação que caracteriza a abordagem desta subunidade responde ao enigma com que um ente humano pensante se depara ao encarar o artifício histórico-cultural que lhe é presumido ao se abster de produzir a própria existência em reciprocidade de coerência e pertinência quanto a intercambiar diretamente com a natureza. Resta explicável, conquanto nunca justificado, que tal complicação não seja enfrentada. É que exercício de poder dispensa o esforço próprio de discernir os sentidos do exsurgir das necessidades vital-básicas e do projetar-se das funções de as atender. Inversamente, entre apenas desejosos de tal dispensa, tem subsistido excesso de esforço no padecer tal atendimento e, por isso, estes desejosos têm estado de antemão impedidos, sob pena de exclusão até fatal, de se dedicarem a percorrer o labirinto dos pertinentes raciocínios. Assim, impasse se torna óbvio, dada a ausência de contestação enquanto prerrogativa da propriedade do poder.

O "modo de existir "privacional"” da escassez imaterialmente criada tem sido facilmente ideologizável como substituto do "modo de ser 'ausencial"" e, por isto, houve de restar usurpante da "forma de ser "interflexa", o que faz a "historicidade" de discernir entre apropriação e produção estar imiscuída com a "historiedade" de criar a condição imaterial da escassez. Assim, cumpre que se assuma "dialeticidade da razão" (pensar modos de existir em oposição a modos de ser), a qual previna ausência de "incontinuidadecontato" como via de ultrapassagem da separação entre duas determinadas oposições: (a) por entre a diferença do "modo de existir "presencial"" das propriedades e a identidade a toda prova do "modo de existir "privacional"" dos objetos de desejo 
irrealizável e/ou ainda irrealizado; e, (b) por entre os sentidos como exsurgem as necessidades e como se projetam as funções de as atender.

O processar-se desse pensar - por entre existir e ser - há de coincidir com um estrito arrazoar dialeticamente. Já este arrazoar tem sido represado, inclusive desde o tempo em que, segundo Abbagnano (2007, 316-322), a dialética era admitida como assunto propriamente filosófico (método platônico e neoplatônico da divisão) e, notadamente, na modernidade (síntese hegeliana dos opostos e sua inversão marxiana).

Ainda antes de Platão (427-347 a.C.) ter chegado a seu método de dividir a ideia, presumidamente aplicável à (socrática) busca de inequivocação sobre os teores deste ou daquele (acreditado) saber, estava difundida entre pensadores gregos a proposta filosófica de Heráclito (c.540-c.480 a.C.), sobre um excludente e conflituoso princípio a mover os seres humanos e todos os demais entes do mundo. À luz deste peculiar princípio e sob pena de autoentrega, por força deste mesmo princípio, ao estritamente ilusório das meras sensações, não caberia alhear-se às necessidades naturais, a começar pelas básicas e por aquelas da reprodução da própria espécie, cujo atendimento teria tido que impedir o pensar até mesmo filosófico. É que, nesta circunstância, todo pensar teria de se reduzir à mecânica de atender essas mesmas necessidades, sob pena de (auto)-perecimento juntamente com a conflituosa materialidade do mover-se das coisas. A princípio, por tácito que ainda o fosse, Heráclito já explicitava a disputa pelo "alcance culturalmente criado" da necessidade de não padecer o direto atendimento das outras naturais ou materiais, uma vez que a solução desse não padecimento sempre implicou guerra contra tudo, em toda parte e a todo tempo, por não ter como se universalizar outra guerra no âmbito da 
estrita subjetividade humana. Entretanto, resta plenamente admissível que, a exemplo do pensar de Heráclito, ainda não era vislumbrado qualquer sentido em o ser humano nascer e subsistir tendo necessidades assim básicas, apesar de que atendê-las, por além das próprias e das requeridas à autoinsustentabilidade das crianças e dos meios de uso coletivo, teria como justificar a parte (o espécime) em relação à totalidade (à espécie).

Outros filósofos, ao longo desse período em que emergiu a filosofia, buscavam um princípio primordial que explicasse a "physis" (o constituir-se das coisas, também enquanto questão de qualidade). À época, não haveria empecilho de este constituir-se estar a ser por eles concebido como confronto entre "ser" (isento de necessidades ou, talvez, tendo estas sempre e de antemão atendidas) e "não ser" (o próprio modo de ser das necessidades, preterido como vazio, privação, negação, nada enfim). Já o pensar a respeito do "ser" tinha como incidir em resposta à busca de não precisar se submeter ao jugo das próprias necessidades, mediante imemorial recurso ao mais fundante e inequívoco dos significados do que jamais deixou de ser idealizado como poder. Ademais, eram pensadores que preveniam recurso às explicações míticas do mundo ${ }^{6}$, apesar de também buscarem poder (exceto, talvez, Heráclito que teria renunciado a honrarias, dadas as contemporâneas ameaças da expansão persa sobre a cidade herdada de seus antecessores) e presenciavam a influência de legisladores e de mercadores na (re)-apropriação dessa busca, peculiarmente após as cidades-Estado na antiga Grécia terem

6 Cabe ter em conta o que expõe Nunes (1999a, p. 59): “Os amplos campos da filosofia foram sendo constituídos como originários da proeminente experiência cultural e política dos gregos, nos terrenos histórico e político do escravismo dos séculos IV e III a.C., criando, a partir desta realidade, as matrizes que justificariam sua universalização" (Grifo nosso). 
passado a ser hegemônicas ${ }^{7}$. Até então, os deuses, assim como os reis que deles diziam descender, eram tidos como a fonte dos saberes então dominantes e cuja continuidade era objetivo de uma arcaica e conservadora educação (Paideia antiga). Inusitadamente, e por tácito que ainda o estivesse, veio a ser a profano-humanidade de tais filósofos a primordial fonte do pensar e da busca de explicações das coisas ou do mundo.

Com Sócrates (469-399 a.C.), entretanto, passa a ser pensada a impossibilidade de universalizar o atendimento de certas necessidades, embora este filósofo jamais houvesse cogitado a respeito de "escassez criada" de tudo o que as atendesse e cujo imaterial modo de existir sempre se encontrara exposto a ser caracterizado como "privacional" vislumbrar algumas necessidades cujo atendimento era raro, por significar o proceder de uma pessoa sábia, justa e virtuosa, além de previdente, generosa e corajosa. Ao mesmo tempo e em reação à forma sofista de apropriar tal significado, surgiam dúvidas quanto a ser ensinável a prática de virtudes, da ética e do autodomínio.

Com efeito, inequivocação (quanto ao que devia ser entendido por essas e outras qualidades humanas) tornara-se

7 A hegemonia das cidades-Estado tornara-se possível, graças, em parte, à monetarização das trocas de utilidades, a exemplo de artefatos de metais (ouro, prata, cobre, estanho e ferro) e de argila (cerâmicas), tecidos e cereais. Conforme observou Aristóteles (2007, p. 67-70), com essa monetarização tornara-se possível ilimitar a riqueza, o que ele admitia como incompatível com limites naturais da produção de utilidades em geral. Assim, não era de se esperar que, àquela época, fosse declarado por Aristóteles algo a respeito de eventuais influências do enriquecimento de mercadores na destituição dos antigos reis e na investidura dos legisladores no governo das cidades.

8 “(...) como qualquer outro que deseja, deseja o que não está a mão nem consigo, o que não tem, o que não é ele próprio e o de que é carente; tais são mais ou menos as coisas de que há desejo e amor (...)" (PLATÃO, 1975 apud NUNES, 2006, p. 111-112). 
recomendável, para a continuidade da convivência social nas cidades-Estado - estas, à época, caracterizadas por Atenas. Ademais, tinha como incidir em assunto socrático ainda compreendido na dinâmica do desejo, ou seja, a ainda perfazer objeto abstrato-intelectualmente disputacional ou erístico.

Buscava-se inequivocação sobre objetos de presumidos saberes, graças a contribuições de peculiares interlocutores e da notória perícia de Sócrates em os induzir a se depararem com equívocos nos teores que compunham tais objetos. Saberes acabavam aquilatados como opiniões ou meras crenças, mesmo que tidos, até então, como verazes por seus detentores. Em síntese, segundo Nunes (1999a, p. 62), "Sócrates apresentou a conduta moral como aquela que brota do interior do próprio indivíduo e não como mera sujeição coercitiva à lei ou ao Estado, superando a justificação pelo determinismo religioso e a legitimidade estreita da submissão à lei" (Grifo nosso).

A respeito de tal interioridade, caberia formular hipótese sobre inato e primordial potencial a assumir virtude, algo que, inclusive hodiernamente, tem restado liminarmente irreconhecível em favor de aquisições vindas de fora da pessoa - desde mercadorias até favores (tidos por) divinos. É que, já em Platão e sob raciocínios do seu (tido por) interlocutor Sócrates, surgiram propostas de ensinar virtudes, ética e autodomínio, recorrendo-se, para tanto, ao proceder dialético cuja idealidade era traduzida por ascese da alma, conquanto, segundo Williams (2000, p. 54), tenha tido um frustrante desfecho9. Essa ascese, segundo Nunes (2006, p. 134-178),

9 “As oposições radicais da República, entre a realidade eterna e as ilusões do mundo material mutável, não apenas deixaram problemas teórico-filosóficos profundos; elas também frustraram os propósitos éticos de Platão" (Grifo no original). 
iniciava-se como filosofia do amor e devia encerrar-se como amor da filosofia, assumindo um teor retórico.

Platão propõe uma nova retórica, na verdade uma maiêutica, uma elevação da retórica pela reta superação dos sentidos e escansão das sensações, uma verdadeira psicogogia, isto é, uma condução da reflexão pela alma até ideias claras e puras. A esse método de elevação dos sentidos, de subida das sensações às ideias e destas às ideias puras Platão chamou Dialética, para ele a verdadeira e única retórica plausível, a retórica essencialmente filosófica (NUNES, 2006, p. 134. Grifos no original).

A propósito de tal ascese, cumpre destacar a referência platônica de que os governantes, homens ou mulheres, à altura das necessidades da cidade-Estado que ele idealizava na sua obra "A República", precisariam de uma paideia que os tornasse tão virtuosos a ponto de prescindirem da disputa pelo poder e serem capazes de assumir gratuidade nas atividades de governar a cidade.

Se descobrires uma vida melhor do que governar, para os que devem governar, podes conseguir um Estado bem administrado. Pois só nesse mandarão aqueles que são realmente ricos, não em dinheiro, mas naquilo em que deve abundar quem é feliz - uma vida boa e sensata. Se, porém, os mendigos e os esfomeados de bens pessoais entrarem nos negócios públicos, pensando que é daí que devem arrebatar 
o seu benefício, não é possível que seja bem administrado. Efetivamente, gera-se a disputa pelo poder, e uma guerra dessas, doméstica e interna, deita-os a perder, a eles e ao resto da cidade (PLATÃO, 2007, p. 216) ${ }^{10}$.

A seguir, Platão apontou a posse da dialética como riqueza acima da prática do poder, mediante pergunta (que atribui a Sócrates e este a seu interlocutor Glauco): "Achas então que a dialética se situa para nós lá no alto, como se fosse a cúpula das ciências, e que estará certo que não se coloque nenhuma outra forma do saber acima dela, mas que representa o fastígio do saber?" (PLATÃO, 2007, p. 232). De imediato, emerge a conclusão: "É também a melhor prova para saber se uma natureza é dialética ou não, porque quem for capaz de ter uma vista de conjunto é dialético; quem não o for, não o é" (p. 234-235).

À época de Platão, divisibilidade de ideias, a presumir a própria dialética como sua fonte, não teria tido como emergir enquanto "incontinuidade" por entre categorias e "contato" por entre suportes reais destas categorias, bem como mediação qualificadora de concepções, o que significou abertura de flancos a críticas já em Aristóteles. Posteriormente, com os neoplatônicos Plotino e Proclo, tal ausência de mediação acabou aprofundada e, com isso, "incontinuidade-contato" deixou de encontrar oportunidade histórica para se desvelar como especificidade dialética, facultando certa licença para realçar determinada especulação filosófica - aquela de que

10 Cumpre rememorar que Platão (c.427-c.347 a.C.) nasceu e conviveu ao longo da derrocada final de Atenas (431-395 a.C.), embora, anteriormente (479-431 a.C.), tivesse sido a mais representativa das cidades-Estado da Antiguidade Clássica. 
tudo emana do Uno. Tal oportunidade somente viria a ocorrer catorze séculos à frente, quando Marx abriu espaço para incidir em dialeticidade a prática revolucionária de desapossar fontes (estritamente objetivas) dos meios de vida, fazendo com que proprietários destas fontes se vislumbrem ao menos ameaçados de adentrar o "modo de existir "privacional", (vazio, imaterial e não sensorial), mesmo que, inclusive a Marx, este modo fosse ainda inacessível enquanto categoria de pensar.

Quanto às críticas, originárias já em Aristóteles, há duas restrições a propósito da pertinente procedência e a serem examinadas: (a) certa autoentrega à dominação cultural, recorrentemente irreconhecível por até intelectuais críticos, tem induzido enxerto de objeções, seja em cepa originariamente sofista, mediante procederes racional-hedonísticos, seja em cepa formal-logicista, mediante procederes desde aqueles dos estóicos até os de seguir as modernas regras cientificizantes do método; e, (b) a "situação epistêmica" do observador tem incidido em uma insignificância também ainda irreconhecível, por coincidir, seja com um inexpressivo ponto da totalidade real-concreta, seja na circunstância de se estar do lado de fora de toda especificidade; tal "epistemia" tem feito com que o específico não passe de uma totalidade cujos componentes interiores permanecem não observados, além de conterem residuais incertezas quanto às suas possíveis influências na totalização.

Quanto a existir abertura para realçar esta ou aquela especulação filosófica, trata-se de avançar em procederes que contribuam, ainda que não propositadamente, para a ultrapassagem do condicionamento originário da "situação epistêmica" do observador a se pautar pelas modernas regras cientificizantes do método em humanidades. A validade de uma tal pauta 
decorre de dominação cultural que condiciona a aplicação da lógica, mediante pressuposição, em vez de produção, de premissas acriticamente fundamentadas. Já estas premissas, ao contrário dessa validade e mesmo que de antemão presumidas, compõem a totalidade histórica que jamais deixa de se encontrar aberta ao irrestrito, ao ilimitado e ao indeterminado. Caso tais premisssas estivessem assim abertas, o proceder de chegar até elas teria de ocorrer como imersão em um miolo problematizado da mesma totalidade e o resultado desta imersão significaria uma produção de alcance endógeno.

Em desfecho, não causa estranheza que a pressuposta fundamentação do teor de premissas incida em meras obviedades (exemplo: todo homem é mortal; Sócrates é homem) ou denote ser artifício originário de dominação cultural, argumento de autoridade, etc, [ex.: “(...) senhor e escravo têm o mesmo interesse" (ARISTÓTELES, 2007, p. 54)]. Alterinamente, fundamentar o teor de uma assertiva implica "incontinuidade" abstrato-representativa e "contato" entre reais-concretos (coisas, entes, fatos e fenômenos), incidindo-se na forma como "incontinuidade-contato" esteja a mediar inserção de inequívoca qualidade dialética por entre a infinitude vazia da "escassez criada" e cada real-concreto em apropriação. Todavia, ao prevalecer aquele artifício, fundamentar premissas incidiria em proceder unilateralmente, o que equivale a inescapável violência empírico-analítica. Já esta violência decorreria de experimentação, seja esta efetiva (sempre e de antemão autojustificável em relação à natureza livre, além de insistentemente reivindicada em relação à humana), seja presumida (resultados de experimentos têm sido interpretáveis de forma alheia às circunstâncias em que acabam objetos de saber, peculiarmente ao permanecerem assim alheados a respeito de procederes cuja qualidade, ainda que favoreça cientificidade, seja inconveniente à dominação cultural). 
A contribuição de Platão precisa ser admissível como deflagratória, pois se trata da primeira e já técnico-metodicamente rigorosa descrição do proceder dialético. O teor dessa descrição cumpre ser destacado.

“(..) dividir (a ascese da alma enquanto
ideia) segundo gêneros e não assumir
como diferente a mesma forma, ou
como idêntica uma forma diferente"
(apud ABBAGNANO, 2007, p. 316.
São nossos os termos entre parênteses).

A ideia a ser assim dividida há de incidir, mesmo que em alcance ainda hipotético, naquela referente à dinâmica do desejo ou do interesse por poder em sentido amplo. Essa ideia tem como ser divisível entre duas formas: (a) aquela do "gênero-propriedade" (objeto de desejo já realizado); e, (b) aquela do "gênero-escassez-criada" (objeto de desejo ainda irrealizado ou irrealizável). Então, não cabe assumir como diferente a mesma forma (a forma-propriedade é a mesma, seja a referente a um bem de raiz, seja a um direito), nem como idêntica uma forma diferente (a forma de objeto de desejo não realizado ou irrealizável - idêntica àquela da infinitude da "escassez criada" - não coincide com aquela de objeto de desejo já realizado).

Certa mudança na proposta de Platão vai emergir na conceituação dialética dos procederes expostos por Huisman (2004, p. 785) como "exercício dialético" dos pensadores neoplatônicos Plotino e Proclo. Esse exercício foi traduzido (do latim até ao português) nos seguintes termos:

utiliza o método platônico da divisão para distinguir as espécies de um gênero, para defini-las e para chegar aos gêneros primeiros; com o pensamento faz combinações complexas 
desses gêneros, até percorrer todo o domínio do inteligível, depois, por caminho inverso, da análise, volta ao princípio (HUISMAN, 2004, apud ABBAGNANO, 2007. p. 316).

Quanto à especificidade de tal proceder, a divisão significa chegar aos componentes (espécies) de um gênero. Assim, a exemplo dos gêneros inerentes à socrática dinâmica do desejo, há real-concreto apropriado e há "escassez criada", os quais têm como cada qual ser dividido. Para tanto, real-concreto apropriado é definível como objeto de desejo já realizado e a ter "modo de existir "presencial",; e, "escassez criada" é definível como necessidade a estar histórico-culturalmente engendrada e tem "modo de existir "privacional". Assim procedendo, as espécies acabam pensadas, ao se indagar: o que corresponde a objeto de desejo já realizado e tem "modo de existir "presencial"? E: o que perfaz necessidade a estar histórico-culturalmente engendrada e a ter "modo de existir "privacional"'? Então, as respostas levam necessária e suficientemente aos gêneros (real-concreto apropriado e "escassez criada"), constatando-se que eles perfazem, complexamente, gêneros primeiros (não há a considerar outros gêneros mais abrangentes do que eles) em todo o domínio do inteligível (o âmbito da dinâmica do desejo, projetado em uma pólis ideal, apesar de presumidamente sustentada por escravos). Retorna-se, assim, ao princípio (o uno da dinâmica do desejo).

E acrescenta Abbagnano (Ibid.):

Aqui o método platônico da divisão, que para Platão é o segundo momento da dialética, tornou-se o primeiro e a ele foi acrescentado, como segundo momento, "o retorno ao princípio"[...]. 
O primeiro momento em Platão tinha como incidir na ideia socrática da dinâmica do desejo e o segundo na divisão dessa ideia segundo os gêneros de um real-concreto apropriado e da "escassez criada". Ambos e somente eles esgotam a dinâmica do desejo - este, a coincidir com a pólis ideal, ou seja, com a plena certeza de fontes dos meios de vida (terras e escravos, à época) no exterior do próprio desejoso. No caso dos neoplatônicos, o primeiro momento é o da divisão dos gêneros, chegando a espécies (subgêneros), cuja interpretação - análise e síntese - faculta perceber que os gêneros são primeiros, dado que o Uno é a pertinente procedência.

Há uma passagem de Williams (2000), em que a divisão de uma linha deve ser pensada, em acordo com ambos esses momentos históricos na explicitação do proceder dialético. Tal linha é dividida segundo dois domínios da ideia platônica que representa o mover-se da ascese da alma. Por sua vez, este movimento tem origem na experiência do cotidiano (as sombras da caverna) e segue em direção a "mais alta" realidade (aquela iluminada pelo fogo no exterior da mesma caverna) - questão que emerge ao menos candidata a assunto socrático do próprio Platão.

Temos que imaginar uma linha dividida em duas secções. A parte de cima corresponde ao conhecimento, e, também, portanto, àquelas coisas que podemos conhecer; a parte mais baixa corresponde à opinião, e àquelas coisas sobre as quais não podemos ter nada melhor do que opinião. Essas duas partes são novamente divididas em subsecções. Quando consideramos essas subsecções, a ênfase não é tanto nas diferentes coisas das quais podemos ter conhecimento 
ou opinião, mas, antes, em métodos mais ou menos diretos de adquirir conhecimento ou opinião (WILLIAMS, 2000, p. 45-46. Grifos nossos).

Tirante à interpretação do proceder dialético constante desta citação, a ênfase recai sobre filosofia dialético-metódica nos níveis das subseções. Nestes níveis, à época, era impossível que entrasse em cena "incontinuidade-contato" como dialeticidade da razão a mediar aspectos da então admitida ascese da alma, em cuja depuração inexistia alteridade de entendimento quanto a fim-começo ou começo-fim que, na interioridade do próprio pensar, demarcasse passagem, não apenas da opinião para o conhecimento ou vice-versa, como também de um para outro dos métodos de adquirir opiniões e/ou conhecimentos. Em tal circunstância, o ponto de partida teria que residir na socrática dinâmica do desejo, desde que pertinente à especificidade de possuir fontes de meios de vida no exterior do próprio desejoso, pois tal dinâmica sempre houve de perfazer real-concretude, cujo significado, para a qualidade do proceder dialético, seria constituir-se tanto mediação quanto divisibilidade técnica ou metódica (razão dos grifos na citação acima), atendo-se, no âmbito do mundo sensível, a estritas diferenças - a nada mais do que "doxas" (opiniões) em Platão.

$\mathrm{Na}$ atualidade, caberia sugerir que, à época, a ideia da dinâmica do desejo precisasse se originar no "sei que nada sei" (apenas acredito saber) do Sócrates real, em vez de na ascese da alma do Sócrates apropriado por Platão. É que, até hoje, "incontinuidade-contato" por entre modos de existir sequer ameaçou se tornar via intelectual-produtiva de opiniões, de conhecimentos, ou ainda, das próprias vias ou métodos. 
Adotando-se tal sugestão, a ideia de como proceder para que, epistemicamente, um real-concreto seja concebido como um todo - restrito, delimitado e determinado - não prescindiria do "modo de existir "privacional" da "escassez criada". Tal ideia sempre houve de emergir no bojo desta escassez, cujo modo de existir tem identidade a toda prova, dada a circunstância de que subsiste como "não ser" (como vazio, imaterialidade ou "essência" imediata da "necessidade superior”, de cujo vácuo a pessoa há de horrorizar-se por significar impossibilidade de ilimitar o poder enquanto transferência para outrem do atendimento das demais necessidades próprias). Trata-se de identidade que tem sido propriamente criada ao longo da "historização" em que superioridade cultural se impôs de forma dominante. Em prol desta (talvez já) hipótese de não ser prescindível um tal proceder com qualidade dialética, cabe visitar e atualizar o "parricídio do nada" (o platônico assassinato de Parmênides enquanto pai da concepção do "não ser”). Assim, Platão

(...) admitiu o ser do não ser e definiu o nada como alteridade: "Resulta que há um ser do não ser, tanto para o movimento quanto para todos os gêneros, já que em todos os gêneros a alteridade, que torna cada um deles outro, transforma o ser de cada um em não ser, de modo que diremos corretamente que todas as coisas não são e ao mesmo tempo são e participam do ser" (apud ABBAGNANO, 2007. p. 810. Grifo no original).

Ainda que se suspeite de mera paralogia, "o ser do não ser" constante dessa citação teria também como incidir na insignificância da "situação epistêmica" do observador, a 
qual, não apenas se desfaz como pretensa topocentria na (inevitavelmente aberta) realidade, como também coincide com o "fora das especificidades", vale dizer, com o vazio, a imaterialidade ou com o imediato e imperceptível modo de existir da "necessidade superior", cujo alcance político tem como se criar dissenso contínuo, o que houve de ser feito às custas da vitoriosa denegação da gratuidade dos excedentes da inequívoca produção dos derrotados.

Então, é necessário partir do que demarca a "situação epistêmica" duma fonte de procedimentos, fonte que ainda não vislumbra que se encontra imersa em absoluta insignificância, vale dizer, subsumida em um "nada substancial" (imaterial infinitude dos objetos de desejo ainda não realizado ou irrealizável). Trata-se de insignificância que sempre foi a ainda irreconhecível condição de quem se restringe a nada mais do que lógico-formalizar. Ademais, é condição a ter que se desvelar, por força de ser detentora da única identidade de fato possível - aquela ininterruptamente criada da imaterialidade da escassez em si mesma. Assim, por hipotético como isto ainda há de acabar formalizado, procedimentos lógicos se caracterizam pela serventia de prevenir aquela descoberta, preterindo-a ou a reduzindo à condição de "lacuna metafísica".

Já a respeito de tal "lacuna", o proceder especificamente dialético faculta perceber que por entre a ideia da ascese da alma e cada um dos dois saberes genéricos que a constituem, bem como por entre estes mesmos saberes genéricos, emerge o que cumpre ser denominado como questão erística ou disputacional.

Como começa ou termina a opinião (talvez passível apenas de diferença) e tem início ou fim o conhecimento (talvez compreensivo de estrita identidade)? E, dado que ambos 
compõem o todo (a própria ideia platônica da ascese da alma), como é que diferença e identidade não se misturam e o próprio todo seja referência da ideia de tal ascese?

Um "vazio" (lacuna) há de acabar presumido para perfazer começo-fim ou fim-começo de cada diferença e de cada identidade, para que a ideia corresponda ao todo (forma superior).

A ideia assim compreensiva de conhecimento e de opinião, caso tivesse que coincidir com a abstrata-representação da "physis" (substrato cósmico que é permanente) na filosofia clássico-antiga, haveria de adentrar tal "vazio" e este de incidir em "meta" (por além do substrato em causa), vale dizer, tornar-se-ia "metaphysis". Para Platão, tal "vazio" deveria ser a alma e a ascese desta seria um inercial mover-se tirante àquele do substrato cósmico a se eternizar.

Ademais, esse mesmo "vazio" houve de permanecer como usurpação da subjetividade e da real-concretude humana de quem soe observar e ser fonte de saberes. Tal usurpação, à base das modernas regras cientificizantes do método, tem incidido na supressão do sujeito em relação a objeto(s), ou seja, na denegação da teoria do conhecimento. Em contrapartida, a fonte de saberes tem precisado se valer da propriedade do que lhe advém do exterior de si mesma, propriedade que lhe serve de orientação para garantir atendimento da "necessidade superior" de poder ou de contar com garantia de pronto e incondicional atendimento das demais, a partir das básicas e da espécie.

Então e em tese, pessoas têm tido que existir, de uma parte, a perfazerem uma pretensa identidade que coincide com infinitude de objetos de desejo irrealizado ou irrealizável (de propriedades externas à própria pessoa), e de outra 
parte, a se apresentarem com diferenças que decorrem de jamais deterem suficiência de reais-concretos correspondentes a esses mesmos objetos. Em ambos os casos, há de subsistir descontinuidade ou não nulas duração e distância por entre a "escassez criada" (fundamento da identidade a toda prova) e o cotidiano (fundamento das diferenças). Por seu turno, tal descontinuidade há de perfazer a insignificância da "situação epistêmica" - esta, enquanto efetividade (caso de poderosos que usurpam o espaço vital de crianças e de suficiências do coletivo) ou mera pretensão (caso de adultos, enquanto apenas forçosamente produtivos).

Garantir o atendimento da "necessidade superior" coincide com impedir que "diastemia" sirva como alteridade de condição que faculte à razão da fonte de procedimentos se inferir por entre o "modo de existir "privacional"” (vazio, carencial e imaterial) da "escassez criada" e "o modo de existir "presencial"” (plenista, disposicional e material) dos reais-concretos apropriados. Entretanto, a oposição entre a insofismável identidade do modo de existir da "escassez criada" e a diferença do modo de existir de um real-concreto apropriado enseja que "diastemia" acabe em alteridade de circunstância para a razão nela se inferir dialeticamente intelectual-produtiva.

"Situação epistêmica" é própria à pessoa ainda autoinsustentável. Valer-se dessa situação para garantir atendimento da "necessidade superior" tem incidido em procedimento exclusivista. Exclusivismo epistêmico é situação, a partir da qual, conceber ideias desanda em unidimensionalismo ainda irreconhecível.

O "modo de existir "presencial" é bastante aos objetos do saber epistemológico, graças a delimitações superficial-externas, aparentes e perceptíveis dos reais-concretos apropriados, delimitações que hão de adequar-se àquelas do alcance 
humano da sua fonte. Assim, exclusivismo do "modo de existir "presencial"' (entre detentores de garantia de atendimento da "necessidade superior") e devotamento à "criação de escassez" com seu "modo de existir "privacional" (entre despossuídos), ambos têm denotado insistência em anular a fonte socrática da conduta moral "que brota do interior do próprio indivíduo".

Deve haver uma espécie de elo ainda não encontrado na busca de especificidade dialética enquanto qualidade no conceber ideias. Tal elo terá que responder à circunstância de a conflituosidade, já em Heráclito, e a radicalidade da supressão de reais-concretos apropriados (comunismo), ainda em Platão, coadunarem-se com questionamentos socráticos às inerências da dinâmica do desejo, a par de que teores correspondentes a tais inerências ainda deverão ser inferidos como saberes condicionados por "epistemia". Quanto ao comunismo em Platão, já Aristóteles (2007. p. 93) considerou-o errado, pois entendia que (sic): “[...] não são as propriedades e sim os desejos dos homens o que precisa ser igualizado, o que é impossível sem uma educação estabelecida por boas leis". Entretanto, no superior e eterno éter da aristotélica dominação cultural, expansão de propriedades sempre atendeu à necessidade de se ter incomensurável certeza do atendimento das demais, a começar pelas básicas e, sobretudo, por aquelas da espécie.

A esta altura da busca da especificidade dialética enquanto qualidade no conceber ideias, outra etapa já seria admissível, a partir da suspeita de que exclusivismo epistêmico e qualidade dialética não tenham como se coadunarem. Com efeito, dialética provém da junção das palavras "diá" (através) e "légein" (falar) e seu significado implica o coletivo. Já a respeito de tal suspeita, cabe apontar que o "modo de existir "privacional"" 
é próprio da insuficiência no atendimento das necessidades da espécie, ou seja, é próprio da insustentabilidade coletiva; porém, esse mesmo modo deverá conter delimitações que adentrem seu próprio bojo, as quais terão de coincidir com o possível atendimento daquelas necessidades em reciprocidade de coerência com o intercâmbio orgânico com a natureza. Cabe também apontar que há o "modo de existir "presencial"" do corpo e dos meios de mantê-lo saudável, cumprindo ao menos vislumbrar "incontinuidade-contato" por entre a diferença do "presencial" e a identidade a toda prova do "privacional".

"Incontinuidade-contato" ainda terá como perfazer alteridade de circunstância para a razão inferir sustentabilidade também coletiva. Já esta circunstância haverá de incidir em forma "diastêmica" e significará oportunidade para prevenir inércia, por além do que é natural, da autoinsustentabilidade da pessoa. Na pregressa e recorrente ausência desta prevenção, o todo daquela fonte houve de sobrepor-se a outros todos, o que tem ocorrido na insignificância deste ou daquele todo, dentre incontáveis outros, da realidade inteira.

Situação assim alterina ainda não teria chegado a ser objeto nem mesmo de especulação filosófica, conquanto tenha sido como que tangida em uma primeira contribuição de Sócrates e, apenas na contemporaneidade, Marx dela se tenha aproximado ao propor despossessão das (tão só objetivas) fontes dos meios de vida. 


\section{Categorias fenomenicamente compreensivas do que está escondido sob o que está manifesto}

Ao abordar o método em fenomenologia e assumi-lo como filosófico, Novaski (2007, p. 79-85) recorre à dualidade entre as abstrações do manifesto e do oculto.

Mostrar e ocultar, eis aí a estrutura de todo fenômeno. A conjunção $e$ entre os dois verbos é proposital: é para enfatizar a simultaneidade que ocorre entre esses dois componentes de fenômeno: ao mesmo tempo que ele se manifesta, se esconde; ele sempre se oculta nas dobras daquilo que se mostra diretamente. (...) com efeito, na estrutura do fenômeno reside o pressuposto inicial e, por ser pressuposto, não há nada antes dele que o explique. E certamente há uma inquestionável coerência do método com esse pressuposto: se há algo sempre e sempre oculto em tudo o que se me mostra, então estou constantemente obrigado a decifrar o que não consigo sequer lobrigar nas dobras do aparente. Ora, decifrar é o mesmo que interpretar e interpretar, por sua vez, quer dizer desocultar o escondido, trazer à tona o que está no fundo, revelar o velado, denunciar o dissimulado. Esse é o método fenomenológico, embutido na descrição que porventura queiramos fazer do que quer que seja sob nossa percepção (NOVASKI, 2007, p. 81-82. Grifo no original). 
Ao longo da leitura desta citação, é-se desafiado a interpretar a própria interpretação, por alheamento ao pressuposto do oculto - ao oculto do próprio oculto. Antes de tudo, infere-se que a "nossa percepção" tem pontos cegos ou costas, por pressupor, de uma parte, recorrente preterição do significado da "situação epistêmica" em que se encontra o observador, e de outra, o mover-se dialético do interpretar por si mesmo. Com efeito, tal percepção não tem decorrido de se questionar ausência de delimitação enquanto fim-começo ou começofim por entre as abstrações do manifesto e do oculto e sem que o próprio método filosófico tenha sido desafiado a substituir esta mesma ausência. Assim, e inclusive para prevenir "lacuna metafísica", cumpre admitir que interpretar signifique remover o citado pressuposto de cada concepção, não apenas às costas da acepção aristotélica de dialética enquanto lógica do provável, mas também incidindo no entendimento da própria dialética como proceder abstrato-intelectualmente delimitativo ou produtivo. À base de tal proceder, remove-se aquela (escondida) pressuposição. Ademais, não há de ocorrer alheamento à circunstância em que o método sempre se esgotou na relação entre processo e resultados deste, preterindo-se ponto de partida ou primordialidade de princípios, inclusive em humanidades. Adentra-se, enfim, ao miolo de determinado fenômeno, aquele da sociabilidade humana, em que, a princípio, o método fenomenológico acabaria por até mesmo se substancializar ou se essencializar.

Ao se interpretar sociabilidade humana, infere-se dualidade que é inerente ao próprio mover-se da dialetização do mundo, dialetização a ser assumida enquanto história das interações entre seres humanos e entre estes e a natureza livre. No caso, o pressuposto apontado por Novaski há de incidir em "vontade" a se "historicizar" como autoimpulsão subjetiva que se manifeste parcial e efetivamente geradora 
de gratuidade em reciprocidade de coerência com intercâmbio orgânico com a natureza humana e livre. Tal "vontade" será inferível como inescapável princípio à gnoseogênese da singularidade subjetiva. Isto, porque o "“ausencial' modo de ser" da "vontade" terá de coincidir com o direto exercício das funções que se voltem para atender necessidades naturais, peculiarmente as de sustentação da espécie, exercício cujo sentido se projeta do exterior para o interior da pessoa, da prole e/ou do coletivo, contrariamente ao processar-se do sentido da vivenciada sensação das necessidades. Assim, perceber a condição subjetiva de tal contrário, por aquém e diversamente da inversão dialética procedida por Marx com sua objetiva práxis revolucionária, ainda virá a ser antítese que, apesar de ainda não dialetizada nem mesmo como lógica do provável, haverá de colocar-se como delimitação no bojo da infinitude do "privacional' modo de existir" da "escassez criada". Dada a direta imperceptibilidade desta infinitude e da "vontade" subjetivamente assumida, passa a ser possível inferi-las enquanto inequívocas e imediatas identidades. Em desfecho, cabe interpretar o significado da remoção do pressuposto inicial do fenômeno, remoção que, em princípio, deve ocorrer a cada concepção em destaque (entre aspas, ao longo desta investigação).

Entrementes, tem havido outro pressuposto que persiste preterido (às costas, em ponto cego ou por aquém do método fenomenológico) e que condiciona percepções cuja procedência se dá a partir de "situação epistêmica" do observador. Trata-se do caráter íntegro da individuação, o qual perfaz a pessoa, o coletivo natural-mínimo e, por potencial que ainda o precise ser, processos humanizadores acentuadamente complexos. A historiedade desses processos permanece meramente futura ou a depender do exercício de funções, cuja efetivação há de significar alteridade de relações transpessoais. Quanto a esta 
alteridade, inferem-se apenas as (ainda e meras) potencialidades da "afetividade" e da "razão" - "razão", por aquém de racionalidade em relação a fins e valores, e "afetividade", por aquém de sociabilidade imersa na infinitude da "escassez criada".

Para precipitar tal historiedade, cumpre assumir a (acima mencionada) “'ausencial' forma de ser por entre sentidos”, na perspectiva de dinamizá-la enquanto intencionalidade pedagógica a se efetivar na "individuação íntegra" do egresso. Porém, o caráter (assim "ausencialmente") íntegro de tal individuação carece de ser inferido enquanto ainda em "formação". Por sua vez, esta mesma "formação" há de ocorrer por entre uma comunhão de necessidades (a se manifestar do humano para outridade deste, para o inumano inclusive, e no sentido de atrair o que as atende para o interior da pessoa), e, uma conexão de funções (a se manifestar em sentido coerente com tal atração).

A individuação, a se assumir assim íntegra, é ainda meramente futura, devir ou "não ser" em relação a tudo que ora está manifesto. E este tudo ainda não passa de um vazio de produtores e de produtos, os quais permanecem represados ou contidos em estritas potencialidades.

Valendo-se das concepções já descritas, "formação" virá a ser concebida como capacitação a se aperceber e se observar na situação por entre dois sentidos que se encontram fenomenicamente escondidos e, por isso, carentes de interpretação. "Formação" cumpre ocorrer como “"ausencial' forma de ser por entre sentidos”, na convergência entre comunhão de necessidades e conexão de funções, assim como em reciprocidade de coerência e pertinência quanto à condição vital-básica das necessidades e à base de direto e/ou indireto intercâmbio orgânico com a natureza. 
Ainda a respeito do caráter íntegro da individuação logo acima inferida, é necessário entender que integridade de caráter adentra incompatibilidade com totalização epistemicamente compreendida, uma vez que, neste alcance de compreendida, a situação, a partir da qual são projetadas as formas de existir, é "historizada" sob radical descolamento em relação ao significado de inserção "por entre opostos", inserção que, alterinamente, lhe facultaria compor uma totalidade. Tal descolamento, que é traduzido por "epistemia", tem coincidido com a irrelevância quanto a diferenciar um todo (compreensão abstrata) de uma totalidade (individuação íntegra), diferenciação que "não convém que ocorra", ao se buscar esta ou aquela especificidade, nem mesmo como fronteiriço começo-fim (ou fim-começo) de componentes daquele mesmo todo. Por sua vez, uma especificidade, ao subsistir epistemicamente aquilatada, tem tido que perfazer um todo, cuja interioridade ainda precisa permanecer irreconhecível naquilo que residualmente o constitua. Por isso, esta interioridade acaba positivo-cientificamente aceita por conhecida, à conta das funções do todo, as quais, por seu turno, precisam coadunar-se com artifício. Já este artifício tem sido extrinsecamente determinado pelo alcance meramente criado da necessidade de o atendimento das demais - as naturais-básicas e da reprodução da espécie - estar "favas contadas", mediante "cercamento" das fontes dos meios de vida e sujeitação de outrem a contribuir para alargar este mesmo cercamento, sob pena de a subsistência dos sujeitados restar de antemão impossibilitada. Prevenir riscos quanto a contar com essa contribuição tem provocado recorrente e predizível obsessão em fragmentar toda especificidade, inclusive na perspectiva de determinar um limite interior.

Em ciências naturais, forma vem incidindo na delimitação aparencial-externa das especificidades, independentemente do 
grau de fragmentação ao qual estas correspondam. Em ciências humanas, todavia, tal delimitação está a acontecer alheadamente à “"ausencialidade' do modo de ser” dos sentidos pelos quais teleconvergem o exsurgir das necessidades e o mover-se das funções de as atender. A necessidade cultural-civilizatória de contar com incondicional garantia de atendimento das demais necessidades, das naturais-básicas antes de todas, adentra imaterialidade cujas fronteiras externas chegam a tanger enigma e até mesmo mistério. Já as funções têm ocorrido concretamente delimitadas e o afinamento delimitativo tem ocultado a concretude dos seus suportes, além de estarem a incidir em objeto de pesquisa em perspectiva experimental-epistêmica de marginalização, informalização e sócio-subjetivação das pertinentes (e violentadas) essências funcionais.

À medida que se conceitue o ser humano com base em forma de ser por entre os sentidos de uma comunhão de necessidades em "incontinuidade-contato" com uma conexão de funções voltadas para atendê-las, vislumbra-se sua (ainda meramente potencial) individuação, singular e/ou coletiva, como "configuração" de "incontinuidades-contatos" dialeticamente situadas - cada uma destas por entre uma necessidade e o exercício da função que a atende. Assim, a totalidade se torna inteira, havendo reciprocidade de coerência e de pertinência entre modos-e-forma de ser. Todavia, à conta da recorrente mediação da dinâmica do desejo e do apoio no " "presencial' modo de existir" da materialidade finita, o "privacional' modo de existir" da infinitude da "escassez criada" tem usurpado a não aparência do " "ausencial' modo de ser" e, com isto, represado a efetivação do potencial de inteiração das possíveis individuações.

Visualizar a situação da "forma de ser por entre sentidos" presume inequivocação quanto a produzir abstrato- 
intelectualmente, conciliando-se método com sua procedência e com resultados cuja obtenção ele condicione. Resta, então, descabido falar de "modo de produção", uma vez que, por si mesma, produção já é via processual e, por isso, "modo" tem incidido em algo de pleonástico e de antemão supérfluo - em algo irracional tal como tem sido o exercício do poder, a usurpar o exercício das funções organicamente compromissadas com o atendimento do alcance vital-básico das necessidades humanas. Cumpre enfatizar tal conciliação metódica e, especificamente, enquanto ela há de coincidir com princípio humanizador. É o que urge ocorrer, a partir da ultrapassagem do período da natural autoinsustentabilidade da prole e, imprescindivelmente, ao limiar da assunção da adultez. Assim, e não por mera coincidência, este limiar e a frequência à universidade perfazem oportunidade cuja postergação tem feito com que o discurso da qualidade, peculiarmente o da excelência do alcance superior do ensino, chegue a adentrar o perfil de "crime de colorinho branco".

Em desfecho, há de emergir o aperceber-se da "razão material-comunicativa". Trata-se de um aperceber-se de modo objetivado, no âmago da totalidade e fora das subjetividades humano-singulares, coincidindo com intercâmbio de utilidades e de ideias. Já este intercâmbio, por restar represado em suas potencialidades, ainda não logrou favorecer pessoas e organizações no sentido de ao menos vislumbrarem a recorrente circunstância em que se encontram imobilizadas - por entre um dilema de subsistência e uma questão disputacional.

O dilema compreende opostos: (a) o bem-estar individual e geral, que ora é vivenciado, teria como continuar possível apesar de uma inaudita redução do esforço que vem sendo despendido sob coerção institucional e sujeitação informal; 
ou, (b) esse mesmo bem-estar seria, alterinamente, várias vezes maior, se esforço equivalente ao já em efetivação contasse com fissuras, brechas ou poros para ser exercido de modo parcial-opcionalmente gratuito.

Questão disputacional tem a ver com a complicação diversamente de complexidade - em que se insere a percepção dos teores desses mesmos opostos, pois a tentativa de assumilos se depara, de uma parte, com renitente desinteresse dos detentores de poder, e de outra, com inacessibilidade histórico-culturalmente criada para pessoas que mais necessitam de os perceber e interpretar.

Em suma, o acesso a tal "razão" sintetiza a necessidade de educar e a função de atender esta mesma necessidade, ao tempo em que projeta os teores da "relação entre prole e quem a sustenta, direta ou indiretamente" como fonte de inclusive instintiva "alfabetização" (instrumentalização quanto a produzir abstrato-intelectualmente). 


\section{Catarse pedagógico-propositiva}

\section{A. "Crítico-teoria" a descondicionar per- cepção e interpretação do fenômeno pedagógico}

A formação do educando não estaria a incidir na transcendência de um artifício que resulta da transformação de uma natureza primordial em outra tentativamente nominalista? Até que ponto o homem movido a estrito apetite aquisitivo coincidiria com um "fora de si" a perfazer aquele transcendental artifício? Educar significaria internalizar na pessoa o mais demolidor dos seus inimigos?

Em alcance propriamente "crítico-teórico", o processo educativo torna-se delator da atuação pedagógica que lhe é constitutiva, porque esta atuação tem sido socialmente condicionada a se transformar em "agência-propriedade" da tecno-ciência - esta, a se tornar excludente, ou seja, nada há de constituir educação, além dela mesma. Nesta condição, e em estreita cumplicidade com o metropolismo, a atuação pedagógica se torna sempre mais funcional à (re)-concentração da propriedade, inclusive de si mesma (apelo ao professor-robô, este já sistemicamente em gestação e a compor bem-de-capital, pouco ou nada importando se este bem vier a ser privado, público, ou mesmo social).

Pedagogia tem sido lide com equivocações. Na dinâmica desta lide, o seu próprio entendimento tem incidido em 
ambiguidades a decorrerem de lentidão do próprio pensar, vale dizer, tem tido de incorrer em imprecisões que têm necessitado coincidir com insignificância de disjunção entre autocognição (da lide sobre si mesma) e objetos de trabalho perceptíveis e "impróprios" (tomados tão somente do exterior das pessoas do educando e do educador). Já estes objetos têm sido acessados de forma responsiva apenas a ensino que, por sua vez, se processa como comunicação e estimulação, ambas contingenciadas ${ }^{1}$, além de (ser tido por) imprescindível e até mesmo suficiente. Em decorrência, a (auto)-percepção e consequente (auto)-interpretação da própria pedagogia ocorrem circunscritas à estrita instância do que é assim "impróprio” e perceptível.

Em tal "cadinho" (auto)-transformativo, e dado que, por si mesma e de imediato, transformação é imperceptível, além de apenas fenomenicamente interpretável no caso das humanidades, o proceder pedagógico tende a incidir na teimosia de transformar cognição heterógena em fonte de autopercepção, ao invés de autocognição em fonte de heterocognicidade. Chega-se, a propósito de tal proceder, a uma insuficiência autorreflexiva, de que constitui sintoma a inclinação a estar totalmente compreendido por conteúdos "impróprios", ou seja, a existir plenamente invadido, sobremaneira por arte comunicacional e por psico-biologia estimulativa. Acaba, por isso, em proceder usurpado, para não dizer colonizado, por conteúdos de disciplinas, os quais, ao serem incrustados no currículo, não devem ocorrer mediados por objeto propriamente pedagógico, por conta de que, para tal incrustação, as "identidades" conteudais pré-existem metodicamente já obtidas. Em suma, a tecno-ciência conta com o apoio do método para excluir: tudo tem sido processo e apenas processo.

1 Contingenciadas porque implicativas de estados de sistemas, numerosos e particulares, os quais interagem em tempo e lugar, ambos determinados (McLAREN, citando SMITH, apud SILVA: 1993, p. 31). 
Assim totalizado, o proceder pedagógico se confunde com certo ensino, o qual sempre precisou valer-se de reapropriações da prontidão de objetos de saber, cujas formas ou abstrato-representações se tornaram, cabal e especificamente, artifícios a serem reapropriados, inclusive em segunda ou demais mãos ${ }^{2}$. Para tanto, e por tácito que o esteja, tal ensino foi obrigado a também perfazer condutas com vezo (re)-produtivo e conservador. Estas condutas, por sua vez, têm sido respostas ao abrangente meio sociocomportamental que o ensino tem tido que (re)-produzir.

Tudo o que está "impropriamente" contido na pedagogia incide no risco de ser transferido para o educando, pois, também este há de imaterializar-se enquanto suporte de assimiladas abstrato-representações. Estas, por sua vez, correspondem a reais-concretos que se situam, tão só, no exterior da própria pedagogia e provêm de duas origens: (a) da natureza, livre ou mesmo (a assim dita) humana, e enquanto matérias estritamente perceptíveis; e, (b) de realizações cultural-civilizatórias que se dão a conhecer sob o vezo reducionista da transformação de algo diretamente perceptível na outridade de signos também assim perceptíveis. Em acordo com esse vezo, torna-se acessível ao educando o dar-se a conhecer da forma abstrato-representativa desta ou daquela realização cultural-civilizatória.

Entretanto, há transformações de uns fenômenos em outros, ocorrências que se tornam apreensíveis ao educando, à medida que gnoseogênese nele se complexifica. Porém, o que no educando há de estar "impropriamente" contido não se

2 Na perspectiva de prevenir meras reapropriações do saber já acabado, cumpre ter em conta a cientificidade do saber escolar, em vez de dada ciência deste saber, conforme anunciado por Nereide Saviani (apud ALMEIDA; OLIVEIRA; ARNONI, 2007, p. 56) como "reinvenção da cultura". 
restringe apenas às transformações de alcance técnico-científico. Origina-se, também, em realizações de perfil carente de "crítico-teorização", ou seja, em feitos que ameaçam não apenas a primordial e real-concreta humanidade do educando, mas também a ambiência de ensino-aprendizagem e até o meio sociogeográfico.

Conotação "crítico-teorizável" do perfil de realizações cultural-civilizatórias em educação traduz-se como falta de reciprocidade de coerência e de pertinência por entre dois pressupostos, os quais têm restado irreconhecíveis por conta de uma (não mais do que convenientemente subsumida) insignificância existencial: (a) um suporte (de ainda inevitáveis "impropriedades") que é a subjetividade do próprio educando, a par de costas ou pontos cegos (também assim insignificantes) da relação ensino-aprendizagem e, inclusive, da sociabilidade no exterior da escola, a derivar de prévia prontidão educacional de egressos; e, (b) a capacidade de conhecer também imperceptibilidades, capacidade cuja autoafirmação tem sido como que abortada, ao ser preterida em favor do acesso a conteúdos estritamente perceptíveis, "impróprios" e pré-estipulados em currículo.

Aquela falta de reciprocidade de coerência e de pertinência implica ceder expansão de espaço real-concretamente existencial-subjetivo para criações imateriais ou para abstratorepresentações de reais-concretos estritamente perceptíveis, além de artifícios cultural-civilizatórios. Assim, ou à conta de tal cessão, "impropriedades" se transformam nos significantes da pedagogia e do educando, significantes que, ao se tornarem difusos, acabam por usurpar também os significados que são presumidos à própria denominação do que seja pedagogia, educando e educador. Os três desandam em denominações que pressupõem uma tácita absurdidade, ou seja, um 
(irreconhecível) vazio de fundamentos real-concretos - estes a coincidirem com as originárias potencialidades do educando e da própria pedagogia.

Dentre as condições em que essa absurdidade se torna possível, encontra-se uma determinada improntidão educacional de pessoas adultas (de egressos), ou seja, carência de profissionais com suficiência da facilmente universalizável capacitação para visualizar a originária e sustentatoriamente incondicional "posse do coletivo natural-mínimo". O alcance sustentatoriamente incondicional desta posse reside no acesso a meios subsistenciais cuja obtenção ocorra estritamente à conta de outrem. E tal capacitação deixa de acontecer, por força do vezo educacional que reproduz estritas perceptibilidades, vale dizer, que insiste em restringir seus conteúdos àqueles aos quais correspondam reais-concretos tão somente em estado pronto, acabado ou final. Para tanto, recorre-se sempre mais a tal estado dos reais-concretos, apesar de o próprio recurso incidir em procedimento de imprescindibilidade apenas sensorial e em racionalidade com relação a nada mais do que fins-valores. Postergam-se, a perder de vista, apelos à razão autocognoscente ou autorreflexiva, porque produção inequívoca e parcial-opcionalmente gratuita não tem mediado o processo educativo, mas o tem feito uma instância à parte e de forma tão ambiguamente compreensiva que não logra orientar sequer o vislumbre do que precisa ser pensado como potencial ou (ainda a advir) real-concretude do educando.

À medida que a capacidade autorreflexiva do pensar constitui resposta ao que é, também e inatamente, humano no educando, há como prevenir que este se torne vítima da sua exposição a estar substituído por excludentes perceptibilidades e, em decorrência, não se reduza a uma capacitação mimético-estética e meramente reativo-motriz. Já as manifestações 
das características desta capacitação costumam reproduzir artifícios cujas diferenças tendem a replicar aquelas herdadas na cultura ou mesmo no real-concreto da natureza já humanizada. Então, a busca pedagógica de capacitar educandos a "celebrar diferenças" tem como restar circunscrita ao não universalizável (ao privilégio ou elitismo). Sintomaticamente, tal capacitação já está sendo admitida na pós-moderna convivência urbano-metropolista ${ }^{3}$, na qual se admite que ela esteja a se impor entre pessoas ou grupos, à conta de coexistência não explicitamente violenta, apesar da estranheza que perpassa as relações entre apropriadores desavisadamente incontidos. Conquanto incidam em tendência elitista, por ser insustentável universalizar o pertinente acesso, aquela coexistência e essa estranheza estão a se constituir, a rigor, nos horizontes mudancistas ou emancipatórios que ainda restam à teorização considerada crítica do processo educativo na modernidade atualmente vivenciável.

Em decorrência de tal insustentabilidade, persiste notória defasagem, junto a acreditados atores sociais, em questões de como perceber e interpretar as condições sob as quais opera o "cordão umbilical" (fonte de sustentação) da atuação pedagógica. Neste sentido, ainda é insuficiente o acesso à complexidade gnoseogenética, acesso que é necessário para aquilatar a complicação do enredamento sustentatório na ambiência urbano-metropolista, enredamento a incidir em elitista (re)-apropriação do que é vendido sem ser comprado na estipulação do monetizado preço final das utilidades, a partir daquelas que são imprescindíveis para se participar da própria produção, ou seja, para contar com o único critério de prevenir seletividade no acesso dos despossuídos até

3 Conforme aplicação à teoria educacional crítica (BURBULES e RICE, apud SILVA: 1993, p. 182-8). 
mesmo ao processo educativo. Assim, nada impede que essa (re)-apropriação continue a perfazer a mais evolutivamente avançada estratégia de a espécie cometer autodepredação. Em desfecho do sucesso de tal estratégia, incide-se em um já absoluto alheamento quanto a relações entre conhecimentos e condutas, as quais tenham como advir em perspectiva inequivocamente melhor ou mais compatível com íntegra inteiridade da própria questão sustentatória.

Entre educadores, ou seja, entre (pré)-ocupados com o processo educativo, também eles egressos deste mesmo processo, cumpre ao menos desconfiar de que as relações entre conhecimentos e condutas têm ficado escondidas sob nulidades, insignificâncias, silenciamentos e quejandos. Apesar de serem reconhecidos por mestres, há educadores que ainda não se apercebem, com a necessária acuidade, da recorrente obsessão por estritas e imediatas perceptibilidades, obsessão à qual se encontram vitimados e que insistem em transferir para ainda meros candidatos a também se vitimarem.

Emerge, ao final, a questão projetivo-pedagógica do perfil do egresso. Definir quaisquer peculiaridades qualificativas desse perfil é objetivo que se tem estatelado contra uma inamovível mesmice. Na perspectiva de sua prontidão educacional, denota-se despreocupação com autoentrega do ex-educando a medir-se pela própria mesquinhez, vale dizer, de costas para suas originárias potencialidades de assumir condutas fora daquelas circunscritas estritamente às não universalizáveis, preterindo desde as primordialmente compatíveis com íntegra inteiridade da questão sustentatória até as que são imprescindíveis a realizações que favoreçam convivência razoável, justa e responsavelmente emancipada. Egresso fragmentado e fragmentário nas suas formas de pensar torna-se incapaz de conceber tais realizações e, menos ainda, de ser partícipe 
de empreendimentos que se voltem para além do próprio umbigo. Socializa-se às avessas, pois se torna incapaz de perceber a forma como teria que dispensar a presença, ou mesmo a contiguidade, de quem ele, sorridentemente, está a agredir, ou então, lugubremente, a defender-se. Não suporta solidão e, apesar disto, não se dá conta de que tudo faz para que existam condições em que ela não tenha como deixar de prevalecer. Não se liberta de apenas presumir circunstâncias nas quais persistem afirmadas suas contradições intelectivas, por força da perpetuação dos paradoxos que decorrem de suas atitudes e condutas. Insiste em continuar desavisado, ou mesmo iludido, restringindo-se a contribuir para que sociabilidade tenha que acontecer inescapavelmente "sincrônico-topocêntrica" (em metrópole preferencialmente única).

Efetividade desse perfil de egresso traduz-se como insistência em naturalizar as implicações da "injustificação" (da matriz das desigualdades políticas, das disparidades econômicas e dos desníveis de acesso educacional à tecno-ciência). Em rigor, naturalizar é atribuir uma tácita insignificância a tais implicações, cujo substrato humano ou cultural-civilizatório há de restar liminarmente desqualificado em questão de reciprocidade de coerência e de pertinência entre forma de pensar e modos de agir, ambos ainda a se tornarem também coletivamente sustentáveis. A propósito dessa naturalização, cumpre admitir que é o alcance propriamente humano de tal reciprocidade que acaba desqualificado, ou pior, denegado, à base de criação de pontos cegos que condicionam as potencialidades humanas a se efetivarem em subjetivo-humanas faculdades ainda caoticamente abstrato-representadas, além de esse mesmo alcance propriamente humano coincidir com racionalidade restrita à relação entre processo e resultados (deste mesmo processo), ao persistir ainda alheio à situação, não só de a pessoa estar inatamente autoinsustentável, como 
também de soltura ética quanto a estar liberta do alcance ainda irreconhecível de seus limites natural-sustentatórios.

Enfim, cabe não subestimar os riscos de o ensino acabar confundido com o que ele mesmo transfere, atribui e faz existir no educando - uma segunda "natureza", a assumir hegemonia sobre a meramente primeira ou ideologizada como primitiva. Trata-se de confusão que tem tido como mediar toda aprendizagem, em prejuízo de mediação discernitiva que possibilite, além de clareza de abstrações, cultura genuinamente humana. $\mathrm{O}$ que cumpre caber no educando, é-lhe já inato, muito embora, por omissão educacional, tenha persistido mero potencial.

\section{B. Autoconcepção da pedagogia na inteiridade da ambiência acadêmica}

\section{Alternativas e alteridade quanto a fundamentar a pedagogia}

Escudando-se em argumentos, por ora não mais do que intuitivamente sopesados, faz sentido abordar uma proposta de ultrapassagem das vigentes especificidades humano-relacionais que configuram ensino-aprendizagem na totalidade compreendida por educação universitária. A justificativa de assim proceder reside em ser já admissível que insuficiências do sentido, que caracteriza o coletivo educacional, passem a se tornar conhecidas em resposta à circunstância de o fenômeno pedagógico vir a ser ancorado na íntegra inteiridade da questão (auto)-sustentatória, ancoragem que lhe possibilite abranger, a par dos próprios conhecimentos e procedimentos metódicos, também inusitadas atitudes de educadores e de educandos. 
Tal ancoragem cabe ser admitida, graças ao reconhecimento de que é imprescindível haver opção também transpessoal para buscar caráter veraz de qualidade de processo educativo como questão propriamente universitária. Visualiza-se, a propósito, que a referida ancoragem há que evocar atitudes cuja alteridade procedimental seja imprescindível ao autoconhecimento como porta de acesso a heteroconhecimento, à medida que a evocação, por si mesma, constitua via de acesso a imperceptibilidades subjetivas e, graças a esta via, àquelas que sejam carentes de objetivação ${ }^{4}$.

Admite-se, a princípio e em rigor, que a qualificação educacional, em perspectiva, há de avançar por um processo autoconstitutivo, apesar de este processo não estar de antemão reconhecível aos necessitados de que seja promovido. $\mathrm{Na}$ perspectiva de tal autoconstituição, têm sido assim também irreconhecíveis certas influências da educação no próprio meio-atitudinal. Dentre estas influências, cumpre ressaltar aquela que tem sido compungida pela circunstância de os objetos de saber só provirem do exterior para o interior do educando. É que acesso tão somente a tais objetos, dada sua tácita e crítico-teorizável correspondência ao que é perceptível, acaba abortivo da originária e inalienável abertura dos educandos à gratuidade da perspectiva de quem a gera, ou seja, ao que é, também, vital-fertilmente imperceptível e que apenas transparece na generosidade juvenil. Outra dessas influências dá-se a conhecer como fetichização do que é assim imperceptível, fetichização que se desvela como impulsão do educando a se buscar no exterior dele mesmo, ou seja, a não

4 A propósito dessa via, educadores a serviço da UNESCO, preferem apelar ao aprender-a-aprender que, por sua vez, é pressuposto para o aprender-a-conhecer, na educação para o Século XXI. Entretanto, é este último que prevalece nas entrelinhas das análises apresentadas (UNESCO. Educação: um tesouro a descobrir. São Paulo: Cortez; Brasília, DF: MEC: UNESCO, 1998. p 92). 
coincidir consigo mesmo. Por força desta busca, fundamentos da pedagogia hão de incidir em alternativas de reais-concretos que, por sua vez e inescapavelmente, têm origem, andamento e terminação tão só no bojo da propriedade.

Busca de veraz qualidade da educação expõe-se a ter que ultrapassar uma ainda "crítico-teorizável" autoentrega de educadores ao "impróprio dogma profano", segundo o qual a mera acumulação de narrativas de saberes se desdobra em melhores condutas - em mudança destas, como usualmente está implícito a falas e escritos. Trata-se de autoentrega que denota um vezeiro alheamento em relação a três questões de extrema relevância: (a) não se leva em conta que fontes de "melhor conduta" perfaçam, de per si, imperceptibilidades; (b) mudança das condutas não tem tido como se dar a conhecer sem incidir na tácita e conveniente insistência em salvar essa mesma autoentrega, porque, sob esta, esconde-se a própria subjetividade; e, (c) incide-se em alheamento quanto a ser necessário prevenir essa autoentrega, prevenção que só há de ocorrer mediante acesso a discernimento entre autoconstituição e (re)-apropriação do próprio fenômeno pedagógico.

Nesta última questão, disponibilidade de tal discernimento denotaria capacidade de pensar cuja alteridade coincidiria com inserção humana no que é, também, vitalfertilmente imperceptível e, neste sentido, imprescindível para tornar íntegro o processo educativo. Trata-se de coincidir, não apenas com anticolonização da pedagogia, como também, e enquanto inequivocação a propósito de produzir, com alteridade de suporte para o campo de atuação pedagógica, no sentido de esta se fazer dialeticamente mediativa na interioridade de todos os demais campos. Para tanto, todavia, cumpre dialetizar intelectual-produtivamente como será possível uma universidade bem diversa da atual. 
Intui-se que inserção humana na inteiridade do que é vital-fértil (inclusa a autossustentabilidade, obviamente) sempre potencializou aprendizagem que, entretanto, tem sido marginalizada, informalizada e sócio-subjetivada, mas que sempre houve de ocorrer em sentido inaudito, original ou surpreendente, além de coincidir com ensino na conjunção entre meio geográfico e agrupamento humano ${ }^{5}$.

A aprendizagem em causa permanece primordial, radical e opcional, por emergir no âmago do processo de perpetuação da vida. Mas, apesar desta origem, ela persiste não valorada, ou mesmo antivalorada. Mesmo assim, jamais se reduziu ao que fosse imediata e prontamente perceptível, específico, objetivo enfim. Para todos os efeitos, ela própria há de fazer-se válida como imperceptível vital-fertilidade.

Assim, e por rara que sempre tenha sido, a resistência do educando à anulação de seu "espaço vital" (seu potencial de imperceptibilidades subjetivas a ainda serem efetivadas, inclusive como valores) precisa compor alteridade de fundamento da pedagogia. E é este fundamento que está em vias de ser confirmado, graças a certo atalho para chegar até ele, ou seja, às interações entre a imperceptível vital-fertilidade da aprendizagem e o sentido íntegro da inteiridade da sustentação.

5 Indícios de teorização crítica da relação em foco foram colhidos junto ao geógrafo-humano Milton Santos e ao educador Paulo Freire. Ambos recorrem às relações entre meio geográfico e agrupamento humano, nas perspectivas, respectivamente, de "alienação do espaço do homem" (SANTOS, Milton. Pensando o espaço do homem”. São Paulo: Hucitec, 1991) e “'locus dialogal’ do mundo ontológico-natural" (FREIRE, Paulo. Educação na cidade. São Paulo: Cortez, 2005). 


\section{Desconstrução da presumida e imprecisa qualidade da educação}

Até certo ponto, as críticas pós-modernistas, assim como as contrárias a estas, já encarregaram-se da desconstrução em epígrafe, feito que, nesta investigação, está a ser aquilatado na perspectiva "crítico-teórica" de se estar a atingir o "fundo do poço da injustificação" (esgotamento da esperança radical de haver melhores condutas no âmbito do que se totaliza pela conjunção de hegemonia política, de abstracionismo econômico e de objetificação científico-técnica).

Apoio científico-técnicista à perspectiva em apreço provém dos teores do "paradigma da insustentabilidade coletiva", em cuja dinâmica, esse "fundo do poço" há de coincidir com o limite tendencial da automação, vale dizer, com a eventualidade de o custo dos meios de produzir, inclusive os de mera subsistência, acabar totalmente subsumido ao valor vendido e não comprado (aquele compreendido por apenas tributos e retornos de capital, ambos enquanto remunerações de estritas propriedades de direitos sobre os resultados da produção), além de absorver parte sempre maior da remuneração de quem precisa participar da produção como único e procedente critério de acessar resultados tão só encontradiços no mercado. Para todos os efeitos, trata-se de um limite absurdo que, apesar disto, está sendo o pós-moderno "norte" do abstracionismo econômico a se compor com hegemonia política e com a própria objetificação científico-técnica.

Não restam quaisquer dúvidas de que a atuação pedagógica está enredada no avanço da automação, nisto sendo liderada pela unidade entre ensino-pesquisa-extensão, peculiarmente se tal atuação for sustentada, direta ou indiretamente, por 
tributos e demais rendas de estrita propriedade. Com efeito, a obtenção e (sobremaneira) a expansão de tributos precisam ser estimuladas mediante institucionalizadas oportunidades de realização de retornos privados ou de estímulo à incontinência (re)-apropriativa. É que, após a vitória da burguesia, aumentos de tributos passaram a depender da perspectiva de positividade na taxa de retornos de capital, destes deduzidos os próprios tributos, tendência que é reforçada pelo endividamento do Estado - pelo "calcanhar de Aquiles" da democracia que está a ser impingida à base de pacto tácito entre Estado \& Mercado, ou seja, sob a obsessão de "fazer voto \& dinheiro" a todo preço.

À luz do (acima mencionado) discernimento entre autoconstituição e (re)-apropriação do que constitui o fenômeno pedagógico, torna-se demonstrável que a incontinência (re)-apropriativa, hoje (tida por) conduta capitalística, seja reforçada por ensino com qualidade conceitualmente referenciada e fixada por estímulos à base de estritas perceptibilidades.

Com efeito, e por escondido que o esteja ocorrendo, estimulação implica em o educando buscar vantagens (lucro em sentido amplo), ao invés de empreender a própria educação de modo inequívoco e opcionalmente. Em tal busca de vantagens, e sob o respaldo organizacional-corporativo, há autoentrega do próprio educando a sucesso narcisista, de alcance simultaneamente político, econômico e científicotécnico, porém incompatível com a íntegra inteiridade da sustentação coletiva, a começar por aquela da sua própria educação.

Em sentido verazmente qualitativo, o educando há de não mais restar abandonado à própria sorte (reduzido a código burocrático), mas adentrar condições de pró-agir em 
reciprocidade de coerência e de pertinência ao caráter íntegro das interações entre alcance pessoal e sentido coletivo da sustentação.

As condições, em que atualmente precisaria emergir tal pró-ação, ocorrem nas antípodas dessa reciprocidade, motivando uma intrigante pergunta: alteridade de condições educativas ainda estaria a ser abortada, ao custo de se niilizar o educando enquanto pessoa singular e esta, para defender-se, precise renunciar à vigente sociabilidade?

Da imperatividade de tal renúncia, seriam sintomáticas duas recorrências: (a) aquela de que o ensino, com sua atualmente presumida qualidade, terá de reforçar o alcance técnico-científico do "fundo do poço da injustificação", uma vez que tende a permanecer técnico-cientificamente escudado e autoentregue à própria incontinência (re)-apropriativa; e, (b) aquela de que a busca de inequívoca qualidade da educação há de persistir alheada ao sentido opcional e ao absurdo da condição forçosa do ato produtivo, a começar pelos atos produtivos que são inerentes à relação entre ensino e aprendizagem.

\section{Autoconstituição da práxis educativa}

Entra em pauta a autoconstituição da práxis educativa, em sentido que seja, o menos possível, eivado de equívocos. Não por mero acaso, tal pauta é aberta pela procedência, mesmo que ainda intuitiva, de um determinado limite das tendências de tal práxis, as quais conduzem ao esgotamento da esperança ou ao aprofundamento do desespero, ambos a serem radica- 
lizados ${ }^{6}$. Com efeito, no âmbito da mera nominalidade da transformação, não tem existido esperança que não se contraponha a desespero, por imperceptível que isto esteja a ocorrer. É que tudo tem tido que acontecer no bojo da propriedade e ali constituir expressão da autoanulativa dualidade compreendida por inclusão e excludência.

Assim, ou melhor, com o fim dos presumidos e incessantemente (re)-apropriados fundamentos do desespero e da esperança, abrem-se horizontes para alteridade de práxis educativa sempre menos eivada de equívocos. Da mesma forma, e antes de tudo o mais, o sentido desta alteridade há que ocorrer fora da propriedade, ou seja, totalmente exterior aos onipresentes tentáculos da incontida conduta (re)-apropriativa.

Os (potenciais) promotores do sentido da alteridade sempre foram os despossuídos de fontes de meios de vida exteriores às próprias pessoas - os inequívocos e anônimos produtores. Eles têm sido vítimados à ilimitação (re)-apropriativa dessas fontes, especificamente por também constituírem-nas. Trata-se de vitimação que, da perspectiva "crítico-teórica", jamais os inocentou em relação ao desejo de também contarem com oportunidades de acessar propriedades assim exteriores e ilimitadas. Têm sido pessoas incessantemente tangidas por necessidades, peculiarmente pelas subsistenciais, situação que

6 Cabe, neste ponto, reafirmar o questionamento de Goergen (2001, p. 36): "Será mesmo que temos que nos resignar à condição de seres resultantes do acaso?” E, mais à frente, emerge uma resposta: "Depois do grande boom do conhecimento, da informação, das habilidades técnicas volta com toda força a necessidade do formativo. Além dos conhecimentos necessários para vencer na vida no contexto de uma sociedade regida pela informação, o educando precisa adquirir a capacidade de orientar-se em meio ao cenário caótico e desdiferenciado, aprender a reconhecer quais são, efetivamente, as questões fundamentais para o ser humano, para a vida e para a convivência. A grande questão é como fazer isto na realidade contemporânea que, como vimos, se caracteriza pela ausência de princípios orientadores" (p. 78. Grifo no original). 
coincide com aquela de não se dispor de condições para transferir a outrem a direta ou inequívoca obtenção dos meios de as atender, apesar e até por conta do avanço científico-tecnológico. Entretanto, e por isso mesmo, não lhes tem sido possível visualizar sentido nas próprias necessidades, inclusive porque sempre ficaram a mercê dos abortadores deste mesmo sentido, vale dizer, dos algozes recorrentemente sovados por eternos e incautos desejosos de imitá-los na busca de lucros a todo preço. Tais abortadores têm sido pessoas que usualmente não deixam de se esfalfar, por além inclusive do que tem ocorrido com as suas vítimas, para promoverem o que, por isto e de modo inconfesso, lhes houve de restar, antes de tudo o mais, conveniente - a ocultação do absurdo que é, para eles, nascer e subsistir tendo necessidades naturais, a serem atendidas, rotineiramente e sob pena de perecimento. E é tal transferência que, em primeiro e pessoal ato "historizado", tem sido uma espécie de confissão da absurdidade em causa.

$\mathrm{Na}$ (vigente) pedagogia, por oculto que ainda o esteja, incide-se em "blasfêmia humanista", ao se admitir que, em alcance propriamente econômico de atividades humanas, a utilidade faça sentido e, por isso, sua inequívoca geração venha a se tornar mediadora do processo educativo. Exemplo de tal incidência, certamente não contextualizada, é a seguinte citação de Erich Fromm (apud SILVA: 1995, 9): "A economia como essência da vida é uma enfermidade mental". Em contraponto, ao menos duas nuances da admissão desse sentido da utilidade precisam vir mais esclarecidas: (a) cumpre não subestimar as circunstâncias sob as quais, na modernidade, os povos que superaram a (elitista e hegemônica) vergonha por avocarem a si condutas abertamente utilitaristas (peculiarmente Grã-Bretanha, sucedida pelos Estados Unidos da América) tornaram-se potências mundiais no exercício do domínio político, do abstracionismo econômico e da 
objetivação científico-técnica; e, (b) em recôndita e pouco ou nada conhecida instituição de ensino superior, ultrapassa-se essa mesma vergonha, ao se assumir que a utilidade adentre sentido, porque, e antes de tudo o mais, também o fazem a pessoa ter nascido e subsistir tendo necessidades, a começar pelas básicas e por aquelas da reprodução da espécie.

Por inaudito que o precise ser, tal sentido se volta para admitir como será possível abalar a sincrônico-topocentria a se originar no bojo da tríade conformada por imperialismo político, epistemismo lógico-formal e objetivismo econômico. Para tanto, basta que sejam abertos horizontes para inequivocação quanto a produzir, enquanto alteridade atitudinal de "crítico-teoricamente" perceber e interpretar fenômenos cuja determinação tem precisado, incondicionalmente inclusive, proceder daquele bojo.

Em alcance "crítico-teórico", faz sentido assumir condutas coerentes com íntegra inteiridade da questão sustentatória, ou seja, constata-se que gratuidade opcionalmente gerada sempre foi imprescindível à subsistência do coletivo natural-mínimo e passa a ser paradigma do soerguimento de coletivos mais complexos, em que a "injustificação" ainda deixará de ser solução à conta de esta somente ser possível ao implicar tantos problemas quantos o forem necessários ao vezo particularista da apropriação das fontes dos meios de vida, dado que inercial autoinsustentabilidade tem incidido em extemporânea e antinatural relação de parentesco com propriedades extrínsecas à pessoa. Ademais, gratuidade forçosamente gerada acabou em injustificável solução sustentatória da complicação institucional que tem sido inerente aos coletivos de existência mais complexa que aquela do natural-mínimo. E a mais convincente das explicações da forçosidade em apreço reside em o processo de gerar gratuidade implicar inevitável e a tanto 
imprescindível exercício de poder. À base deste processo é que o poder houve de ser impingido como solução à custa de criar a própria falta de soluções. Em contraponto, à luz de gratuidade opcionalmente gerada, uma forma acentuadamente "menos pior" do exercício do poder teria como advir de opcional devotamento à antidepredação da própria espécie humana. Caso isto ocorra, será anulada a absurdidade de precisar ser forçosa a geração de gratuidade.

\section{Ultrapassagem de equívocos quanto a identificar faculdades humanas}

Faz sentido assumir opcionalmente geração de gratuidade, porque tal atitude há de coincidir com o exercício da inequívoca "vontade" pessoal-humana. Neste seu sentido, "vontade" seria denotada pela circunstância de ser efetiva a práxis pela qual se dissolvem entre si desequivocação quanto a produzir e ocorrência deste mesmo produzir, ou seja, com a ultrapassagem da "historização" da pessoa que se vitima à exploração, inclusive "de" e "por" ela própria. Isto presume autopoliciamento a favor do que é liminarmente indesejável, por ser inclusive antiprazeroso, vale dizer, a favor de assumir, também fora da propriedade própria, esforço e/ou resultados deste. Ademais, inequívoca identidade do que é assim indesejável terá de substituir o absoluto prático ou histórico-dialético do materialismo, ao facultar que se interprete divisão do trabalho enquanto também trabalho e este se anule por compreender tese e antítese de si mesmo. Com tal substituição seria visualizável o que signifique propriamente "vontade", tendo-se em conta impulsão para exercer atividades humano-produtivas a acontecerem, em boa parte, fora da propriedade e, sobremaneira, fora do desejo de a pessoa se restringir ao alcance prazeroso do apropriar. 
Em uma situada perspectiva alternativo-institucional, somente antipredação incidiria em justificativa para a "vontade" restar como que subsumida à perceptibilidade de exercício de poder, pois, neste caso, ela teria que se "historicizar" como impulsão para coibir abuso de incontinência do desejo ou de ilimitação do acesso a propriedades. Ausência de antidepredação, a par da circunstância de a geração de gratuidade estar sendo postergada para a esfera do liminarmente irreconhecível, ambas - ausência e circunstância - são situações em que se torna sobre-humano exercer inequívoca "vontade". Todavia, o que faz propriamente sentido é a sobrehumanidade desse exercício, pois somente ela há de ao menos tanger inequivocação quanto à própria questão de sentido.

Dentre as procedentes oportunidades de produzir de modo inequívoco e parcial-opcionalmente gratuito, há de advir, antes das demais, a busca de veraz qualidade de uma educação pelos próprios educadores. Nesta perspectiva, a busca, por ela mesma, terá de se voltar para a "individuação íntegra" do educando, ou seja, para a ultrapassagem da sua originária autoinsustentabilidade ainda a corresponder ao estado caótico das interações entre as suas potenciais e represadas faculdades. Trata-se de procedimento que visa a abrir oportunidades para a "vontade" pessoal evadir-se de equivocações sobre si própria e seu exercício, o que significará prevenir vitimação do educando à extemporânea continuação daquela sua autoinsustentabilidade. Neste horizonte procedimental, terão que fazer sentido, tanto a utilidade que é inerente às questões sustentatórias (abertura à crítica na condição de teoria), quanto a despossessão do coletivo (desafio de pedagogia propriamente "crítico-teórica"), ambas - utilidade e despossessão - pertinentes à construção de condições que favoreçam acesso, o quanto possível precoce e aprofundado, 
ao "discernimento entre apropriar e produzir", ou seja, à via "crítico-teórica" para autoconhecimento e à via interpretativa para heteroconhecimento.

A “individuação íntegra" ocorrerá, porque o "ausencial” sentido do modo de ser da "vontade" implicará em a sua inequívoca identidade vir a ser, não apenas a antítese da identidade do "modo de existir "privacional" da "escassez criada", como também o vértice em que virá a se tornar inferível uma cabal incontinuidade - minimalidade de distância e duração - por entre aquele sentido e tal escassez. E será concomitante, a tal inferência, a oportunidade de a escassez deixar de ser criada ou de produção ser opcionalmente empreendida, tornando-se enfim perceptível o "ex-desejo incontido" (a "afetividade", enfim também inequívoca, graças à generosidade que lhe é característica como "meninice" a jamais se esgotar na "historicidade" da pessoa). Já aquela incontinuidade há de incidir, por si mesma, no momento de a "inteligência" se enxergar "interflexa" (em reciprocidade de coerência e de pertinência) entre "afetividade" e "vontade", incidência que perfaz, também subjetivamente, a relação espaço-tempo. Por sua vez, a situação assim "interflexa” da inteligência facultará à razão se assumir como "incontinuidade-contato" por entre as autoafirmações do sentido do modo de ser da "vontade inequívoca" (exercício de funções a atenderem necessidades naturais) e da "afetividade inequívoca" (emotividade humana a se externar como congraçamento intersubjetivo no exercício de funções). Então, os signos correspondentes a "forma" e a "formação" também devem se afirmar, uma vez que os correspondentes fundamentos hão de se tornar inferíveis, perceptíveis e interflexos desde o "miolo" da pessoa. Tais fundamentos hão de corresponder a uma tríade minimamente grupal-natural de faculdades humanas, não apenas possíveis, como também entre si irredutíveis ("afetividade-razão-vontade"). 


\section{Projeto pedagógico, a abrir-se à própria alteridade}

\section{1. "Alteridade de concepção dialética" de ser humano e de sociabilidade}

A individualidade humana nasce potencialmente capaz de se reproduzir e de cooperar na reprodução da totalidade da qual emerge e na qual subsiste. Trata-se de potencialidade que se efetiva, à base de "intercâmbio material-comunicativo" e em reciprocidade de coerência e de pertinência quanto ao fazer sentido das próprias e naturais necessidades, uma vez que a condição para ele começar e permanecer a existir implica a natureza, a livre e a de seus semelhantes.

Todavia, não lhe é de antemão facultado efetivar tal potencialidade, porque, nesta questão e ao exercer liberdade que também lhe é característica, somente lhe tem sido possível remediar, em vez de prevenir, implicações quanto a incidir em omissão própria ou dos seus pares. Ademais, a natural condição de o indivíduo nascer e subsistir tendo necessidades, a começar pelas básicas e de atendimento rotineiro, constituilhe vivência cuja interpretação ele conceitua, não apenas a partir do seu interior ou em circuito fechado, como também do seu exterior ou em circuito aberto. Em ambas estas procedências, há um ativo adentramento em estranheza, ruptura, ou mesmo violência, com relação à natureza, inclusive à de seus semelhantes, sendo que, em relação a si mesmas, pessoas têm transferido e/ou padecido este mesmo adentramento, em vez de encará-lo.

As concepções pessoais, correspondentes às vivências, tornam-se marcos subjetivos e, nesta condição, facultam à 
pessoa se situar, assim como inferir e aquilatar decorrências de se posicionar, ativa ou passivamente. Caso se negasse a assim se situar, necessitaria que algo ou que outrem lhe fizesse as vezes, ou então, pereceria. Mas, tal situar-se tem como ser aquilatado, pela própria pessoa, em uma dualidade de perspectivas: (a) assumir diretamente intercâmbio orgânico com a natureza; ou, (b) agir no sentido de condicionar algo ou outrem a dar conta de tal intercâmbio, o que, por seu turno, tem incidido no alcance mais originário do significado de (auto)-instrumentalização.

Não restam quaisquer dúvidas de que instrumentalização tem prevalecido. Com efeito, a evolução da sociedade se desvela ou se "historiza" como criação de instrumentos e como apelo a estes, ou mesmo a outrem que a tanto tem estado coagido e/ou sujeitado, para que o alcance orgânico daquele intercâmbio com a natureza tenha como indiretamente se efetivar. E, a prosseguir tal "historização", o desfecho há de incidir em substituição do ser humano por robô, por este emergir de antemão apropriado e, desta forma, conceder a seu senhor a condição de "eleito" para o adventício "paraíso" da automação.

Entretanto, este desfecho não deve terminar em soluções nas quais cumpriria apenas acreditar, mas em problemas a se enredarem em uma espiral de contraditórios e de correspondentes contradições. É que inequívoca solução implicaria em alteridade de questionamento das vigentes formas de propriedade, as quais têm constituído excludentes critérios de acesso aos resultados de atividades em processo preferencialmente automatizado de obtenção dos meios de vida. Trata-se de questionamento cuja intestina conflituosidade há de se defrontar com uma provável combinação de duas renovadas circunstâncias: (a) desperdícios ecossocialmente insustentáveis 
para remediar conflitos em acentuada proliferação; e, (b) explicação em bases científico-tecnológicas das recorrentes injustificações.

Com efeito, beiraria contrassenso duvidar de que aumente a probabilidade de se incidir em tal combinação, tendo-se em conta a drasticidade de adentramento em estranhezas, rupturas e violências, cujos reais-concretos os indivíduos hão de abstrair nos circuitos dos seus pensamentos, sem ainda terem ultrapassado o primitivismo de seus critérios no condicionar algo ou seus semelhantes a dar conta da reciprocidade de coerência e de pertinência quanto ao alcance orgânico do intercâmbio com a natureza.

Qual ser humano e qual sociedade seriam capazes de se familiarizar com um tal contexto das relações de apropriação dos resultados do processo produtivo?

Busca de resposta a esta indagação não tem como ser deflagrada, sem que se recorra a alguma especulação filosófica em relação ao mundo do trabalho. Por sua vez, esta especulação se limitará a propor que tão somente no exterior de toda propriedade será possível aventar alteridade de saída para ultrapassar o primitivismo de critérios no condicionar algo ou seus semelhantes a meros instrumentos. Aventa-se, para tanto, insuficiência da positividade das ciências, inclusive das requeridas metodologias, adentrando-se dialeticidade inerente ao real-concreto da dinâmica do desejo e ao da "individuação íntegra", assim como à fenomênica estrutura entre o que se encontra oculto e o que está manifesto na vigente sociabilidade.

A extemporânea continuidade da "posse do coletivo natural-mínimo", à base da relação entre pessoa e suas extrínsecas propriedades, coincide com a reprodução de um 
condicionamento do pensar. Assim, descondicionar o pensamento do educando em tempo oportuno há de significar cooperação com a natureza que lhe é estrutural, assim como oportuna abertura cultural à despossessão daquele coletivo. Todavia esta abertura tem tido como acabar prevenida, mediante criação de injustificações a coincidirem com prevalência de privilégios no âmago da vigente sociabilidade. Trata-se de prevenção que denota, aponta e até delata omissão educacional, no sentido de antecipar "discernimento entre apropriar e produzir" com inusitados desdobramentos atitudinais, a partir do que ocorre na própria relação ensinoaprendizagem.

Ultrapassar tal omissão adentra desafio que, ao ser enfrentado, prenuncia três e sucessivos momentos na relação entre ser humano e sociedade: (a) individualidade ainda naturalmente autoinsustentável, com seu pensamento a ter origem na situação tempestivamente epistêmica, assim como na incondicional "posse do coletivo natural-mínimo", coletivo este que lhe constitui experiência de sociabilidade alterina e carente de evocação; (b) indivíduo que já intenciona buscar autossustentação em alcance também coletivo, com sua "dialeticidade da razão" já biogeneticamente madura para confrontar, de uma parte, autoentrega à dinâmica do desejo "versus" parcial-opcional empenho na geração de gratuidade, e de outra, despossessão do coletivo natural-mínimo "versus" substituição da posse deste coletivo por propriedades extrínsecas à própria pessoa; vale dizer, em vias de conceber e assumir sociabilidade aberta à sua própria alteridade; e, (c) "individuação íntegra" com sua "crítico-teoria" em plena evidenciação, a assumir sustentação também coletiva e a vivenciar situação básica e inarredável, tão duradoura quanto a própria espécie humana - aquela situação que há de corresponder a uma espécie de "ínfero-referencial" 
("incontinuidade-contato") por entre, de uma parte, apetite para construir a absurdidade, e de outra, "afetividade inequívoca" (congraçamento) a se apoiar em razão dialética paradoxalmente ousada e modesta, além de favorecedora, respectivamente, de alteridade de relações humanas e de enfrentamento do desafio de produzir de modo inequívoco e opcionalmente empreendido.

Cumpre referenciar tais momentos a condições vivenciadas por correspondentes avanços em aprontamento educacional: (a) estudante a frequentar, desde pré-escola, passando por educação fundamental, até concluir o ensino médio; (b) universitário, ou indivíduo, em fase de assumir condição de inequívoca adultez; e, (c) egresso do processo educativo, desde o nível universitário até pós-doutoramento, assim como especificidade da pós-graduação para educadores que sejam capacitados a fazer com que o real-concreto do campo da pedagogia passe a mediar, sobremaneira em sentido autodescolonizante, todo o complexo de uma universidade à altura dos desafios ora enfrentados pela humanidade.

Em desfecho, a cientificidade do saber escolar, uma vez dialeticamente entendida, há de assumir condição categorial de área de saberes, ao par com as demais. Então, os reaisconcretos que perfazem o campo da práxis educativa teriam como não continuarem reduzidos a pedestais de dominação. A contextualização desses saberes tem como prevenir a reprodução das injustificações, mas, para tanto, o momento da instrumentalização da pedagogia histórico-crítica incidiria em criticidade, carecendo da aprofundada mediação a provir de especificidade dialética, tirante à acima apresentada. 


\section{Práxis coletiva, conexa à "interdisciplinari- dade" e à "avaliação também por produção"}

Práxis coletiva, em reciprocidade de coerência e de pertinência ao caráter íntegro da individuação, há de ancorar-se em inequivocação ou "crítico-teoria" quanto a efetivamente produzir, ancoragem que requer "interdisciplinaridade" e “avaliação por produção”. Em seu sentido propriamente "crítico-teórico" e por denotar atitude a ocorrer emancipada e emancipadora, tal práxis precisa emergir ancorada no caráter opcional da geração de gratuidade, o que lhe constitui "vacina" contra vezo injustificador das relações sociais. Por sua vez, essa ancoragem passa a servir de referência, fundamento, base e até espaço vital, para que seja constatável produção de índole "interdisciplinar".

Nas antípodas da pretensiosa intencionalidade de sobrepor-se a quaisquer totalidades, há o sentido do inequívoco modo de ser da "vontade", cuja "ausencialidade" (direto ou imediato caráter imperceptível) guarda reciprocidade de coerência e de pertinência à opção de se ser parcialmente gratuito nas atividades de cunho educativo, diretas ou indiretas. Percepção e interpretação do sentido do modo de ser da "vontade" tornam-se imprescindíveis para que ocorram atitudes, ou mesmo condutas, as quais denotem caráter verazmente coletivo das atividades assim educativas. É que esse caráter não significa presença dos educadores em reuniões, porém "dialeticidade da razão" enquanto "incontinuidadecontato" por entre "vontades" e "afetividades", denotando caráter íntegro de cada qual e de todas as pessoas empenhadas em buscar veraz qualidade e precisa cientificidade da educação a promover. 
Chegar a essa denotação é processo que presume reflexão a respeito da prática docente, aquilatando-se grau de acesso ao sentido do modo de ser da "vontade", ou seja, à inequivocação quanto a efetivamente produzir. Por sua vez, esta inequivocação se dá a conhecer, mediante real-concretizações a perfazerem produção de índole "interdisciplinar" e prontamente exposta a ser avaliada. Paralelamente, "afetividade" se torna inequívoca ou livre de interesse, ao ser consentânea com produção e à medida que produzir coincida com subtração da "vontade" ao desejo não realizado e/ou irrealizável. Enquanto tal produção não acontecer, a "vontade" continuará fadada a emprestar o inalienável sentido do seu (homogêneo, incomensurável e aberto) modo de ser à incontinência apropriativa da dinâmica do desejo, nos modos e na forma de esta dinâmica existir. Então, para a "vontade" coincidir com sua subtração ao desejo torna-se imprescindível que haja oportunidade de educandos e educadores produzirem de modo inequívoco e opcionalmente empreendido, ainda que este produzir tenha que ocorrer enquanto mero rito de passagem. Para tanto, cumpre recorrer a "trabalhos interdisciplinares", em cuja execução incidam duas ou mais disciplinas. Assim, a aplicabilidade de teores disciplinares passa a ser aquilatada em um único produto que, já ao ser projetado, confere sentido também operativo às especificidades dos conteúdos de ensino.

$\mathrm{Na}$ (pós)-modernidade, produzir implica que reais-concretudes correspondentes a objetos de ciências venham a se constituir em um amálgama, ao longo da produção de um bem ou serviço, ambos a deterem utilidade. Todavia, esses objetos correspondem a fundamentos reais-concretos que subsistem, cada qual segundo modos e forma especificamente determinados e que, por si sós, não perfazem tal amálgama. Têm de entrar em contato uns com os outros, o que se traduz como 
objetivos cuja efetivação depende de suas diferenças - entre si incontínuas e reciprocamente inferíveis - corresponderem a determinadas funções. Assim, tem de existir profissionais, ou seja, pessoas conhecedoras de fundamentos reais-concretos para que estes entrem em mútuo contato, à base das funções que lhes expressem as especificidades. No caso, e antes de acontecer esta ou aquela produção de um bem ou serviço, aquele "tem de existir" corresponde à necessidade-problema cujo atendimento-solução implica em "interdisciplinaridade" e que, ao longo do processamento do bem ou serviço, há de perfazer "interdisciplinarização".

Em tal contexto, "interdisciplinaridade" responde à necessidade-problema de se chegar, antes de tudo o mais, à "individuação íntegra” desta ou daquela pessoa. Trata-se, então, de educar de modo inequívoco e opcionalmente empreendido. Todavia, educar só ultrapassa mera intencionalidade, porque "tem de existir" (é "interdisciplinar") sua própria utilidade, determinação que é deflagrada ("interdisciplinarizada") pela mediação do discernimento do que seja produzir em contraponto a apropriar, no âmbito de cada campo de atuação e de cada real-concreto ou fundamento de disciplina. Para tanto, é insuficiente, apesar de imprescindível, o mero ensino de tal discernimento. Atividades-fim "têm de existir" (perfazem caráter "interdisciplinar"), a par de que as pertinentes produções têm de coincidir com o que fundamenta o significado do que cumpre ser admitido como “avaliação por produção".

A propósito desse fundamento, resta até mesmo truístico sopesar que esteja presumido entendimento sobre inequivocação quanto a efetivamente produzir, a começar pelo produzir serviços educacionais. 
Caráter "interdisciplinar" de trabalhos implica produção e esta faculta aquilatar aprendizagem, em sentido que previna reducionismo avaliativo, a exemplo de prevenir apelo a um escalar em que notas restem hierarquizantes de diferenças de pessoas e de coisas, diferenças que acabem (pseudo)-identificadas por funções generalizadamente atribuídas. Contrariamente a tal reducionismo, produção inequívoca e opcionalmente empreendida denota "individuação íntegra". E é em prol desta individuação que se torna admissível o caráter propriamente "interdisciplinar", à medida que este caráter traduza autoafirmação de inequívocas faculdades humanas.

Com efeito, as energias vitais da pessoa se esgotam até mesmo em pleno repouso do organismo, fenômeno cuja emergência faculta conceituar necessidades, a exsurgirem do interior para a aparência da pessoa. Entretanto, energias vitais precisam ser repostas no sentido do exterior para o interior do indivíduo e à conta de funções a serem exercidas coerentemente com este mesmo sentido. Para tanto, ao menos três faculdades humanas "têm de se fenomenizarem" em alcance mais inferível: (a) "afetividade" (desvelamento da necessidade de outrem, no congraçamento entre pessoas e a provir da subjetividade); (b) "razão dialética" (fulcro da interpretação dos sentidos entre si contrários, segundo os quais se movem as energias vitais); e, (c) "vontade" (vértice, a partir do qual as energias vitais acabam por seguir sentido contrário àquele das energias em esgotamento).

Reciprocidade de coerência e de pertinência, quanto ao mover-se das energias no âmbito de uma mesma pessoa, coincide com a faculdade de aplicar tais energias, ainda antes que se esvaeçam mecanicamente, para que outras tenham oportuna reposição. Há, ao final, real-concretização do indivíduo, porém o caráter íntegro do pertinente fenômeno responde 
primordialmente à autoafirmação da "vontade", uma vez que reversão do sentido das energias vitais precisa ocorrer no exterior da pessoa, ocorrência que fundamenta o significado do que seja utilidade. Diz-se no exterior da pessoa, porque o inevitável esgotamento das energias vitais tem como ser preventivamente aplicado no sentido inverso àquele do emergir das necessidades, desde que sejam despendidas na obtenção de fontes de reposição daquelas que se esvaem, o que tem de ocorrer com sobras em relação às efetivamente esgotadas. Todavia, ao ocorrer no exterior da pessoa e dada a multiplicidade de pessoas, tal obtenção de fontes tem sido transferida a outrem, cuja sujeitação tem como substituir a (inequívoca e denegada) "vontade" do sujeitador e do próprio sujeitado. Neste caso, energias vitais de sujeitados "têm de estar" aplicadas em lugar daquelas de pessoas que denegam a própria "vontade", por subsumirem-na como "motor" do próprio desejo. Para tanto, e por si mesma, a utilidade se torna "pomo da discórdia", o que explica, sem que se justifique, a intrigante conveniência de ela não compor educação. É que essa conveniência tem ocorrido como educação "cidadã", própria da "pólis" a se metropolizar e do apelo a uma determinada democracia que "tem de se historizar" como igualdade de oportunidades não universalizáveis. Já esta igualdade tem emergido (aparentemente) fundamentável tão só em direitos e, em contrapartida, houve de ocorrer escudada na desigualdade do exercício de obrigações, exercício que, apesar de obviamente passível de universalização, tem sido represado no âmbito da subjetividade. Assim, o sujeitado tem incidido em exclusão do acesso à gnoseologia, o que presume a preterição da gnoseogênese ou do específico meio para a atuação da pedagogia.

Em síntese, a "maiêutica da vontade" (subtração do mover-se pessoal para fora da dinâmica do desejo, vale dizer, dispor-se, opcionalmente, a gerar "gratuidade") coincide com 
o deflagrar do processo de o ser humano e de a sociabilidade se tornarem íntegros. Apesar disso, "vontade" tem sido forçada a não se manifestar em sua inequívoca identidade, pois, no caso de se manifestar, não subsistiria o que persiste de oculto na "historização" da política e da pólis. Para uma desequivocação do que seja propriamente "vontade" cumpre aventar brechas, fissuras ou poros, os quais têm sido ocultados pela incontida apropriação do "intercâmbio material-comunicativo".

\section{3. Às costas da pós-modernista "atitude limite"}

Atitudes anti-injustificadoras da vigente sociabilidade presumem empenho pessoal de educadores e de educandos na perspectiva de chegarem ao caráter íntegro da própria individuação, assim como da objetivação desta como atitudes e reais-concretizações de significado assim anti-injustificador. E, a propósito desse objetivo-desafio, entram em pauta, de imediato, certos questionamentos em pedagogia crítica ou inconforme com pertinente pós-modernismo, os quais traduzem desespero a propósito da invalidação do conhecimento e abdicação de iniciativas educacionais que visem a ultrapassar implicações do sistema de dominação. São questões que já extrapolam a condição de desafios, adentrando verdadeiros impasses.

Apesar da pouca ou mesmo nula utilidade de revisitar dialogações em busca de saídas junto a certa amostra de autores, peculiarmente Shapiro (apud SILVA, 1993, p. 103-140), assim como Morrow e Torres (apud TORRES, 2003, p. 229-263), cumpre destacar a insistência no que cabe, segundo Kisiltan e outros (apud SILVA, 1993, p. 220-225), entender por "atitude limite", apenas paralógica no âmbito do iluminismo e tirante 
à via filosófica seguida pelo feminismo. Partindo da conduta do "scholar" kantiano e passando pela descrição foucaultiana dessa mesma atitude, haveria como prevenir paralogia (tardiamente) iluminista na confluência de dois horizontes: (a) rejeição da autoevidência da contraposição entre unicidade do todo social e dualidade inerente a este todo, à medida que o próprio vínculo social deixa de estar naturalizado e passa a compor uma parte do projeto pelo qual cada pessoa intenta constituir-se na própria autonomia; e, (b) busca de um caráter público (participado, comum) de uma educação na qual a pessoa se veja em uma espécie de labirinto cujos muros se dispõem, autonomamente, ao avanço de quem busca saída.

Já a via feminista, ora revisitada como promessa quanto a assumir alcance paradigmático no âmbito de ambos esses horizontes, traduz-se nas relações implícitas, porém negadas, entre os seguintes pares de signos: Verdade x Poesia; Razão x Loucura; Lógica x Paixões; Significado x Corpo; e Ser x Absurdo ou não existência. Atribui-se uma espécie de "coeficiente de feminilidade" aos segundos termos desses pares, os quais, porque servem de necessárias contrapartidas aos primeiros, acabam como que silenciados, secundarizados, enfim, naturalizadamente diferenciados.

Ainda que críticos venham a dizer que abordagem de tais contrapartidas tenha que constar tão somente em nota de rodapé, urge tecer um argumento cuja formulação mereceu reforço a partir de considerações de Habermas (2003. II, p. 159-170) a respeito de "uma mudança na compreensão paradigmática do direito” (p. 162-163), dada a (exemplar) circunstância de que "A materialização do direito, que a princípio visava a eliminar a discriminação das mulheres, produziu efeitos contrários (...)". É, todavia, desmentida a condição daquelas contrapartidas por uma inegável subjetividade feminina a 
efetivamente se emancipar, peculiarmente ao longo da atual ou tardia modernidade, em que até o sujeito gnoseológico está em franca exclusão do seu tradicional estatuto categórico. Assim, em contexto (de paradoxal simultaneidade) de ousadia e modéstia, o que real-concretamente estaria a explicar tal emancipação talvez resida em mulheres estarem a trabalhar duas ou três vezes mais do que o faziam anteriormente, dado que o moderno "intercâmbio material-comunicativo" lhes possibilita conquistas que ultrapassam, já a perder de vista, aquelas vivenciadas pelas mulheres entre povos helênicos, inclusive antes dos séculos IV e III a.C., quando elas lograram se tornar cidadãs.

Cumpre ressaltar que o sentido da procedência da práxis coletivo-pedagógica, avaliada por produção ou "interdisciplinarizada", não chega a se indispor contra essa "atitude limite", mas não tem como navegar ao largo da circunstância de que também essa mesma atitude esteja a incidir em (re)-apropriações de signos e fundamentos reais destes, vale dizer, continue perfazendo sociabilidade funcional ao avanço das injustificações, assim como à insignificância de disjunção por entre agressão e defesa.

A título de teste corroborativo da validade de tal "atitude limite" e da diferença feminista, considere-se o alegado silêncio a respeito do corpo, vale dizer, preterição do sentido de nascer e subsistir tendo necessidades, as básicas e as da espécie, antes de todas as demais. Ora, até ao senso comum sempre foi admissível que o corpo feminino, associado a abundâncias no meio geográfico, jamais deixaram de se constituir no "norte" da ocupação do Planeta, vale dizer, se a feminilidade e seu corpo, em vez de a "meninice afetiva" neles recorrente e por eles motivada, não estão a ser apregoados de cima dos telhados, este fato não impede que a dominação política e a 
ambiguidade agressivo-defensiva, ambas exercidas sobrepostamente à feminilidade e ao corpo, sejam menores do que as dos pertinentes signos, para efeitos de intercâmbio apenas parcialistamente comunicativo. Ademais, em sano senso comum, quem não admitiria que a humanidade teria chegado, já em tempos imemoriais, ao fulcro de todas as utopias, caso discernimento e práxis inequivocamente produtivas tivessem como se constituir em imprescindível condição do acesso ao corpo do outro? A emergência da possibilidade de descolonizar a feminilidade e seu corpo teria como prevenir as mesmas injustificações que a própria colonização sempre reproduziu?

No contexto desta investigação, a procedência da práxis coletivo-pedagógica ${ }^{7}$, avaliada por produção ou "interdisciplinarizada", é imprescindível à busca de inequivocação a propósito de qualidade e de cientificidade em educação. Para tanto, ela precisa estar ancorada no produzir de modo inequívoco, além de contar com, pelo menos, abertura à potencialidade de esse produzir acabar opcionalmente assumido. Entretanto, tal ancoragem tem de incidir em paradoxo comportamental: ou perfaz atitudes às quais se acessa no processo educativo ou é injustificada implicação da criação de obrigações apenas para outrem, criação que perfaz desde o cotidiano mais sofrido até as mais extraordinárias realizações cultural-civilizatórias.

7 A procedência em apreço não tem como dispensar ousadia e modéstia, peculiarmente no que diz respeito à (acima intuída) "incontinuidade-contato" ou "dialeticidade da razão". Paralelamente, entra em cena a urgência em compensar a teimosia que insiste em se esconder nos labirínticos resultados de pesquisas quanto a procedimentos "interdisciplinares", resultados que sequer chegam a ultrapassar meros "cercamentos", compungidos por busca de como "lotear" conteúdos de disciplinas (PAVIANI; BOTOMÉ, 1993. JANTSCH; BLANCHETTI, 2001). 
No caso dessas realizações, entra em pauta tudo o que (anteriormente) já está explicitado, a respeito de se estar a cavaleiro da confusão entre produzir e apropriar, assim como tudo o que se volta para antitetizar essa confusão enquanto ao menos hipóteses em reciprocidade de coerência e de pertinência à real-concreticidade do caráter íntegro da individuação do ser humano.

No que perfaz atitudes, todavia, há uma questão pouco ou nada trazida a debate, sobremaneira e intrigantemente, nestas poucas décadas de (admitida) pós-modernidade. Trata-se do sentido da liberdade como valor intangível (questão a ser abordada na unidade da síntese logo adiante discutida).

Entrementes, cumpre retornar ao alcance extraordinariamente situado do sentido histórico-crítico da pedagogia, na perspectiva do exame sobre o deslocamento do horizonte da modernidade em Habermas (1990, p. 11-18), uma vez que "o fato de fenomenólogos ainda não terem engendrado o seu 'pós' os torna quase suspeitos” (p. 11). É que os "pós-ismos” (pós-modernismo, pós-metafisismo, pós-estruturalismo, pósempirismo e pós-marxismo) compreendem determinações históricas:

(...) o elemento especificamente moderno, que atingiu todos os movimentos do pensamento, não reside tanto no método, como nos motivos do pensamento. Quatro motivos caracterizam a ruptura com a tradição. Os tópicos podem ser caracterizados da seguinte maneira: pensamento pós-metafísico, guinada linguística, modo de situar a razão e inversão do primado da teoria frente à prática, ou seja, superação do logocentrismo (HABERMAS, 1990, p. 14. Grifo no original). 
Desses motivos, cumpre assumir aquele do "modo de situar a razão", porém, contra a racionalidade mesma, à medida que, nesta, a própria razão estaria a se instrumentalizar. Incidir-se-ia, então, em um (ainda hipotético) situar-se que seria capaz de exercer influência nos outros três.

Nessa (hipotética) perspectiva, a "inversão do primado da teoria frente à prática" há de acabar surpreendida nos contrafortes da colonização da pedagogia, em que "a psicologia do desenvolvimento de Piaget e a teoria da linguagem de Vygotski encontraram evidências suplementares que comprovam que nossas realizações cognitivas estão enraizadas na prática das relações pré-científicas que existem entre pessoas e coisas" (HABERMAS, 1990, p.15). À base de tais assertivas, o pensar espontâneo teria tido que ser pós-modernistamente erradicado e substituído por artifícios cuja instrumentalidade reste no mínimo suspeita. Já "dialeticidade da razão" há de opor, ao artifício do logocentrismo, gnoseogenia a emergir do interior para a superfície da subjetividade, denotando vivência das necessidades, vivência que, ao se fazer presente nas espontâneas atividades do cérebro, teria como atilar o substrato natural-humano dos sentidos e, com isto, favorecer o pensar.

\section{Qualidade e cientificidade da educação a promover}

A título de antecipar o que precisa advir à relação ensinoaprendizagem em decorrência da implementação do projeto pedagógico, conforme logo acima fundamentado, urgiria que educadores intuam o significado de eles já terem dialetizado autoconhecimento e se apercebido de que isto também lhes facilite acessar heteroconhecimento. 
Tal intuição tenderá a evocar uma surpreendente capacidade de atribuir valor a objetos de conhecimento, uma vez que estes hão de corresponder a fundamentos reais-concretos mediados por sentido.

Em tal perspectiva, a própria urgência em assim intuir assumirá seu sentido. É que o caráter dialético do autoconhecimento há de incidir em acentuada aversão à mesquinhez humana, a começar pela pessoal-própria e ou por aquela mais domesticamente cultivada. Trata-se de aversão que decorrerá do autoconvencimento quanto a ser imprescindível assumir atividades parcial-opcionalmente gratuitas, a par de que anuir a esse autoconvencimento coincidirá com guerrear contra nada mais do que sua própria fonte e sem outro ônus do que aquele de se desabsurdizar.

A princípio, autoconvencimento a assumir gratuidade haveria de se defrontar com as inconsequências do mais cínico dos conservadorismos, não fosse o heteroconhecimento quanto a alternativas de se continuar a guerrear contra tudo e contra todos, no bojo da propriedade, o que tem coincidido com entregar-se à absurdidade em construção.

Por isso, uma tal restrição heterocognitiva significará que a pessoa se depare com horizontes entre si radicalmente opostos e que, de imediato, possibilitarão que ela, enfim, se situe em condições de coincidir consigo mesma, ou seja, dar-se conta de que, até então, estivera autoestranhada ou fora de si.

Será esta descoberta que fará a educação encontrar seu imprescindível sentido.

Educar tem sido imprescindível ou, a rigor, alterinamente institucional, porque, antes e acima de tudo, tem havido autoentrega à mesquinhez humana nas ainda inescapáveis relações sociais em que se enredam as possíveis, ou 
mesmo já reais, vítimas da alienação. Proliferam injustificações (exploração, coerção e sujeitação), inclusive na própria e pseudoautônoma subjetividade, da qual talvez seja o mais notório exemplo a possessão pelo "espírito do capitalismo" em Max Weber (1983).

São relações a se processarem de forma açambarcante, hierárquica e de fora para dentro da pessoa, porque mediadas pela (ainda imperceptível) intencionalidade político-dominativa que institui até mesmo definições curriculares.

Para ultrapassar tal institucionalidade da educação, não bastam "virtudes comunicativas" a mediarem as práticas políticas e as (ditas) formativas. Estas práticas carecem de abertura a opções de sentido radicalmente alterino, vale dizer, abertura para processar-se como (auto)-produção inequívoca e opcionalmente empreendida - a rigor, nas antípodas da mesquinhez.

Urge, então, que sejam engendradas opções curriculares, mediadas por "crítico-teoria" ou por discernimento entre apropriar (oportunidades de educar de forma equivocadamente institucional) e produzir (serviços educacionais de modo inequívoco e opcionalmente empreendido).

A procedência desse sentido alterino se fundamenta na tensa coexistência entre liberdade e autossustentação, ambas em alcance inequívoco.

8 Têm a ver com práxis educativa mediada pelo abstracionismo econômico, a se sobrepor, na pós-modernidade, ao próprio vezo político-dominativo: “[...] tolerância, paciência, respeito pelas diferenças, uma disponibilidade para ouvir, uma inclinação para admitir que se pode estar enganado, a capacidade para reinterpretar ou traduzir as suas próprias preocupações de forma que as tornem compreensíveis para outros, a autoimposição de uma disciplina de forma que outros possam 'ter vez' para falar e a disposição para se expressar honesta e sinceramente” (BURBULES; RICE, apud SILVA: 1993, p. 197). 
Por isso, entrarão em pauta inauditas oportunidades para educar as novas gerações, além de vir a ocorrer incessante recurso a algo que se assemelhe a certo teor "aborígene" da "dialeticidade da razão".

Apelo a significado aborígene dessa razão será imprescindível para contemporizar assimetria entre aprendizagem qualitativamente dinamizada e (ainda inaudita) mudança criticamente produtiva, contemporização a ocorrer entre a generosidade juvenil e a ambiência educacional, assim como entre generosidade de egressos e o futuro da ambiência humano-geográfica local e regional.

Por último, mas não menos situadamente "interflexa", emerge a admissibilidade de a "individuação íntegra" se constituir em antídoto de (sempre mais ameaçadoras) frustrações.

Com efeito, insucessos pessoais, grupais, ou mesmo macrossociais, no que diz respeito a (auto)-realizações, passam a ter como justificativa, anterior e mais profunda que outras também disponíveis, precocidade e intensidade da carência de tal individuação.

Assim, ao contrário do que se apregoa aos quatro ventos sobre "a" vigente qualidade, ou mesmo a excelência, do ensino superior, a justificativa em causa consola e reanima na perspectiva de enfrentar o (inglório) cotidiano, além de ir ao encontro de situações já contempladas na metanarrativa cristã do servir e na marxiana epopeia contra a exploração.

Basta a evocação desse antídoto para que se caracterize um inaudito avanço em qualificação e cientificização do processo educativo. 


\section{Das percepções sincréticas à síntese}

\section{A. Autoridade educacional e a questão do valor intangível da liberdade}

Da perspectiva da juventude e na ausência de também cultural despossessão do coletivo natural-mínimo, educação sempre se desvelou como algo de antemão impingível por autoridade que se faz valer já em tal coletivo e na ambiência escolar. Não fosse algo assemelhado com inata generosidade, a provir da própria subjetividade e em resposta a atenções a ela eventualmente devotadas, educar teria de acabar incidindo em uma espécie de "injeção indolor" de imaterialidades (signos e seus significados, ideias, conceitos, valores, hábitos, atitudes e habilidades). É que, por paradoxal que o seja, estudantes têm precisado ser generosos para se capacitarem, não apenas para não mais o serem, mas inclusive para darem conta de como quantificar e aquilatar o quanto lograrão fazer do que seja contrário à sua juvenil generosidade.

Educadores se encontram condicionados por uma pregressa formação. Ainda que esse condicionamento não esteja a contribuir para injetar gananciosidade em seus alunos, não há como negar insuficiência de capacitação pedagógica para evocar generosidade. Já a formação dos alunos tem ocorrido curricularmente determinada no sentido de chegar a um perfil de egresso que manifeste assimilação das mencionadas imaterialidades, ao tempo em que esta assimilação não 
ocorre mediada nem mesmo por discurso sobre gratuidade da perspectiva de quem a gera. Cabe, então, indagar: haveria na ambiência assim formativa uma omissão a se traduzir como "venda e compra" de uma sócio-subjetivada antítese da generosidade? Tratar-se-ia de uma fenomênica particularização do sentido comunicativo do intercâmbio, pela qual esse sentido se torna manifesto à custa de ocultar o alcance também material deste mesmo intercâmbio?

Admissibilidade desses questionamentos e de correspondentes respostas passa pela desocultação da "vontade" humana que tem estado recorrentemente subsumida ao alcance " privacional' do modo de existir" da "escassez criada".

Com efeito, a condição "ausencial" do sentido do modo de ser da "vontade" tem impedido que se avalie o grau de influência da inequivocação quanto a efetivamente produzir na ambiência acadêmica. Já este impedimento tem desandado em prevalência da liberdade como questão de valor intangível. Por sua vez, a prevalência desta questão de valor tem feito com que indiferenciação entre apropriar e produzir se encontre, por tácito ou inconfesso que o ocorra, convenientemente insignificante.

Em contraponto a tal conveniência, a própria insignificância constitui mote para a práxis coletiva de gerar gratuidade se autoafirmar sem risco de se expor a usuais intolerâncias. Ademais, a opcionalidade quanto a ser partícipe de tal autoafirmação acomoda as ideologias que se escudam no intangível valor da liberdade, enquanto, por si mesma, a opcionalidade não frustra, antes até previne, inequivocação quanto a caráter veraz de qualidade educacional. Assim, para convalidar sua "historicidade", a autoafirmação daquela práxis há de presumir que se perscrute a questão da liberdade nos labirin- 
tos ideológicos em que esta mesma questão acabou instalada desde tempos imemoriais.

Alcance intangível da liberdade tem sido realização cultural-civilizatória. Já inequivocação quanto a ser livre presumiria percepção e interpretação da diferença entre apropriar e produzir, ambas - percepção e interpretação - a decorrerem de a "crítico-teoria" se traduzir em práxis coletiva de gerar gratuidade, mesmo que esta tradução tenha que ser conjunturalmente experienciada pelo educando sob a conotação de mero rito de passagem ao longo da frequência à academia.

Já a procedência desta assertiva reside na circunstância de que o exercício da liberdade teria que ocorrer em reciprocidade de coerência com sustentabilidade também coletiva, sob pena de inescapável incidência em injustificações. Por sua vez, tal circunstância não viria a "cair do céu" e a sua eventual existência significaria "alteridade institucional", ou seja, produção inequívoca acabaria opcionalmente empreendida por ser interpretada como imprescindível à liberdade de todos, em vez daquela "historizada" para ser efetiva apenas a poucos, ou mesmo a um só - o senhor, o rei ou o dono do poder.

Assim, a opcionalidade de produzir de modo inequívoco comporia o exercício da liberdade, em vez de o suprimir tal como vem sendo cultural-civilizatoriamente assumido. Trata-se de supressão que tem sido insistentemente criada, à base de sempre mais privilegiada autoinclusão em direitos e autoexclusão das obrigações que são imprescindíveis ou naturalmente institucionais, além de se reportar a ideologias que apregoam universal inclusão em direitos e silenciam sobre discriminada heteroincludência em obrigações não rejeitáveis, mesmo que se perceba e se interprete como injustificada a atribuição (destas mesmas obrigações) apenas aos politicamente menos iguais. 
É em tal perspectiva que nada há de estranho em a mediação político-dominativa, com sua intencionalidade recorrentemente imperceptível nos bastidores do atual e globalista abstracionismo econômico, estar acompanhada por um (místico) encantamento com a prerrogativa científica do método e com os avanços científico-técnicos. É que ambos - método e avanços - vêm perfazendo condições liberatórias da fonte humana de obrigações inequivocamente produtivas, além de incidir em oportunidade de os liberalistas "salvarem positividade de saldos" para a expansão dos seus patrimônios em sentido o mais amplo possível. Para tanto, esta expansão tem de estar cabalmente ideologizada como produção, ainda que, para tanto, os partícipes das ideologias precisem se esconder atrás de biombos organizacionais e ali se transformarem em fontes de recorrentes e multifacetadas condutas apropriativo-particularistas, hoje denominadas capitalísticas. Afinal, não têm existido melhores condições do que aquelas dos labirintos das organizações para, inadvertida e facilitadamente, a pessoa humana se alienar em propriedades que lhe são extrínsecas e ter como se devotar a nada mais do que criar obrigações para estranhos, para despossuídos de tais propriedades e de, a estes, transferir a direta e inequívoca obrigação de obter meios de vida em reciprocidade de coerência com intercâmbio orgânico com a natureza e com o caráter também coletivo da sustentabilidade.

Alterinamente, ainda há de fundamentar-se a única autoridade procedentemente real, ou seja, a educativa, pois a nenhuma outra cumpre arbitrar suspensão da liberdade, por mais que isto ainda precise se delimitar a mero rito de passagem. Já a necessidade ou o problema da passagem por esse rito tem a ver com as recorrentes oportunidades para egressos consentirem em acabar sustentados de forma injustificada e injustificante, à conta da sujeitação de outrem que lhes gere 
sobras de produção, a tanto, cultural-institucionalmente transformadas em direitos. Por seu turno, esta transformação desanda em requisito para silenciar a respeito do sentido de aquelas sobras serem gratuitas. E este silêncio perfaz condição para que essas sobras sejam forçosamente impingidas. Todavia, à base de autoridade educacional, torna-se oportuno, imprescindível inclusive, o apoio do caráter dialético da razão.

Perceber, conhecer e remediar, ou mesmo prevenir, exercício equivocado da liberdade, a desandar em obrigações discriminatórias contra outrem, têm sido desafios cujo enfrentamento talvez precise ocorrer sob efetiva influência de minorias aborígenes, peculiarmente de pele parda e negra, porque ainda não aceitaram as lições de como se obcecarem por ilimitada acumulação de propriedades. É que, à conta dessa obcecação, seria ingênuo admitir que tais desafios sejam encarados até mesmo no discurso politicamente correto, inclusive naquele da razão comunicativa oriunda da teoria crítica e mediadora de uma teoria educacional também igualmente crítica. Por indispensável que esse discurso tenha sido à busca reconstrutiva do conhecimento, cumpre alertar que ainda se encontra tergiversantemente liberalista ao se omitir de imputar significância ao discernimento entre apropriar e produzir, assim como à práxis deste discernimento.

Em sentido inequivocamente alterino e apesar de ainda não se ter sobressaído na história, uma (eventual e assim aborígene) razão há de se refletir e de se realizar em três horizontes do "espaço vital" para o futuro da própria espécie: (a) horizonte em que há de se tornar acentuadamente visível a absurdidade da ilimitável exploração humana, associada à da natureza livre; (b) horizonte em que acabará ridícula a mesmice comportamental de fontes de poder e de (re)-concentração sincrônico-topocêntrica (metropolista) da fixação, 
obtenção e destinação de excedentes gratuitamente obtidos, (re)-concentração atualmente puxada por economicismo precificista e financeirista; e, (c) horizonte de contraposição, a ambos os anteriores, da alteridade atitudinal de assumida fonte de gratuidade, o que, em sentido desalheadamente emancipatório, há de se tornar imprescindível à instauração de sintonia entre as gratuidades de fonte humana e natural-livre.

Apelo à procedência aborígene da "dialeticidade da razão", conquanto de antemão excluso da superioridade cultural, há de reforçar acesso à alteridade de opções curriculares, pois está em pauta a íntegra inteiridade do processo educativo. Ademais, e apesar de o fenômeno pedagógico compreender comunicação interpessoal e estimulação biológico-psíquica, os saberes aprendidos na academia se expõem a estar mediados por opaca intencionalidade político-administrativa e a incidirem em riscos de serem totalizados em alcance tão somente particularizado e específico, ou seja, são ameaçados de redução a estrito teor científico-técnico. Já os riscos, em apreço, têm origem em descolamento, a ocorrer por recurso à comunicação e à estimulação, assim como, e em decorrência deste recurso, a desandar em geração de "lacuna metafísica" por entre forma e conteúdo. Recorrendo-se ao sentido estritamente comunicativo do intercâmbio, tal descolamento tem acontecido por entre significado e significante e em resposta a um outro que tem sido criado à base de estímulos, aquele entre significante e seu real-concreto artificial e só posteriormente (pseudo)-fundamentante. Ambos são descolamentos que não passam de insignificâncias disjuntivas e, por isso, implicam em instituir a (in)-justificação de si mesmos, tendo-se em conta que esta (in)-justificação se faz mediante (re)-apropriação de imaterialidades, estas a se multiplicarem fragmentadas e fragmentárias - como condições existenciais inercial e institucionalmente também criadas. 


\section{B. Uma "pequena narrativa" da (in)-justifica- ção das instituições vigentes}

Alheamento ao alcance também material do intercâmbio, à conta de estímulos ao descolamento entre significante e seu artificial e (pseudo)-fundamentado real-concreto, tem desandado na preterição do caráter íntegro da totalidade do intercâmbio e favorecido que a racionalidade comunicativa se "historize" como particularização da razão humana, apesar das sinalizações em contrário, as quais, recorrentemente, têm incidido em ensaio para a dialeticidade desta mesma razão ser intuída como alteridade de desalheamento.

A excludente superioridade cultural-civilizatória do Ocidente tem respondido a estado particularizado da razão, o que acarreta o paradoxo de que injustificada e injustificante imaterialidade contraste com abundante riqueza material. É que imaterialidade tem sido indissociável de desejo e de interesse no sentido de constituir e até substituir riqueza e, por isso, houve de persistir como primitivismo de incapacidade quanto a prevenir a usurpação do natural esgotamento do parentesco pelo acesso a propriedades extrínsecas à pessoa. Paralelamente, o que importa considerar é a recorrente autoentrega da política educacional, inclusive da educação política que é inerente à competência pedagógica, à reprodução dessa usurpação e daquela superioridade.

Um sintomático registro de tal primitivismo, a se perpetuar na particularização do alcance comunicativo do intercâmbio, já emergiu em versos do memorável estadista ateniense Sólon (apud ARISTÓTELES, 2007, p. 67): "O homem não conhece, porém, nem fim nem medida Que a natureza imponha a arte de enriquecer". 
Obviamente que nada tem sido mais primitivista do que autoentrega às dinâmicas do desejo e do interesse. Por sua vez, essa autoentrega está sendo estimulada por imaterialidades que perfazem, inclusive na atualidade e segundo Saviani (2005, 12), a natureza da educação, por estranho que ressoe uma tal concepção de natureza. Ademais, estimulação coincide com falso atendimento da necessidade ou falsa solução do problema de o parentesco (ou de a "posse do coletivo naturalmínimo”) não se esgotar em termos culturais, o que, levado às últimas implicações, significaria retornar à condição fetal ou ao reencontro com o "paraíso perdido" do cordão umbilical no ventre materno.

Antítese a essa via de permanecer primitivista acabou também registrada, por inconfesso e tácito que o tivesse de ocorrer, nas entrelinhas de texto sobre intercâmbio entre as tribos dos (ditos) bárbaros, texto da lavra daquele mesmo filósofo.

$\mathrm{Na}$ família primitiva, tudo era comum a todos, mas, quando ela se dividiu em partes, os objetos foram também divididos entre estas, ficando alguns privados de algumas coisas; daí a necessidade de trocas. Essa prática é verificada ainda hoje (época de Aristóteles) entre inúmeros povos bárbaros: se uma tribo tem de sobra o que falta a outra, elas trocam o que possuem a mais; por exemplo, trocam vinho por trigo, e assim por diante. Este gênero de transação não está, pois, contra a natureza nem constitui uma espécie separada da ciência da riqueza, visto que, na origem, 
não tinha outro fim senão o da satisfação das necessidades da natureza (Aristóteles, 2007. p. 68. Nossos os termos entre parênteses).

A propósito dos teores dessa citação, resta preterido algo que explique, sobremaneira que justifique, a divisão da família primitiva. Esta família era e ainda é, em resíduos aborígenes, "o" todo, cujo fechamento à totalidade tem ocorrido à base de comum familiaridade com fetiches. Os concretos de pensamento estavam a se restringir à produção que, por sua vez, sempre fora determinada por necessidades naturais e atendimento destas. Trata-se de determinação que não tem sido mediada por discernimento entre o particular (propriedade) e o coletivo (devoluto), dado que a vital-fertilidade humana tem como espontaneamente se dividir entre uma parte "propriamente" autorreprodutiva e outra "impropriamente" heterorreprodutiva. Na insuficiência da espontaneidade desta divisão, adentra-se um dilema: ou o parentesco se mantém estreito pela proliferação de meras tribos, ou então, o trabalho é culturalmente criado em seu alcance enfim sígnico, ao compreender o impingimento da obtenção do "impropriamente" heterorreprodutivo também para estranhos, o que houve de fazer com que a estranheza se tornasse objeto cultural de interesse ou de conveniência e a oposição entre a cultural estranheza e o natural parentesco implicasse transformação social do todo em totalidade - sociedade.

Historicamente, não há como admitir que a desventura das Cidades-Estado gregas, assim como a ventura daquelas que as sucederam até o advento do mercantilismo, sejam explicadas por restrição à “arte de enriquecer”, paralelamente à "historização" das venturas e desventuras a que 
recorrentemente foram expostas as atividades comerciais e bancárias de populações de origem semítica ao longo das suas diásporas, inclusive forçosas e irreversíveis, no Oriente e no Ocidente.

Enquanto separada de conteúdo, forma tem tido sucessivas denominações (notoriamente, a dialética ou ideia superior de Platão, o intelecto agente de Aristóteles e a razão iluminista), o que não impediu a expansão da índole de criar impérios, desde o persa, passando pelos helenistas e romanos, até chegar aos desvarios fascistas e nazistas, entre os anos de 1920 a 1945 do século XX d.C. Durante esse longo período, apropriação particularista da forma em questão só foi ameaçada pela então importância de certo princípio, quando, segundo Russel (1982, p 37), o bispo Ambrósio (340-397 d.C.), em sua popularmente apoiada e heróica não entrega de uma igreja de Milão à ariana imperatriz Justina, deflagrou uma tentativa, conquanto ainda tópica e logo a seguir desvirtuada, de religação entre forma e conteúdo. Ambrósio "demonstrou que havia matérias em que o Estado devia submeter-se à Igreja, estabelecendo, assim, um novo princípio, que mantém até hoje sua importância" (Grifo nosso).

Em tal perspectiva, não resta despropositado recorrer à "dialeticidade da razão" para precipitar alcance íntegro da totalidade do intercâmbio, indo ao encontro de um horizonte que Marx abriu, certamente sem disto se aperceber, à base do que, segundo Manacorda (2007, p. 64), constituiu "flerte" com a dialética no seu pensar por contradições a se fundamentarem na real concretude de contraditórios. Nesse específico recurso, entram em consideração as contradiçõoes que constituem mediação por entre as categorias simples dos valores de uso e de troca. 
Com efeito, intercâmbio tem como ser interpretado a partir do miolo da própria totalidade, miolo que coincide com "incontinuidade-contato" (forma) por entre seu alcance material e seu sentido comunicativo ou imaterial. Para tanto, todavia, o valor de uso ou a utilidade das atividades humanas, e/ou dos resultados destas, precisariam guardar consentida reciprocidade de coerência e de pertinência à sustentabilidade também coletiva, o que implica reciprocidade com trocas orgânicas com a natureza, livre e/ou humana.

Assim, ao se considerar que a própria totalidade do intercâmbio ainda tem sido insuficientemente dinamizada na história, torna-se admissível que as instituições tenham apresentado prerrogativas cuja criação ocorra mediada por imaterialidade recorrentemente separada de materialidade e a separação entre ambas tenha permanecido, interesseira e convenientemente, sempre irreconhecível. Paradoxalmente, a socialização do ônus, correspondente aos sempre mais agigantados desperdícios em que incide tal separação, tem implicado excesso de gratuidade forçosamente impingida à fonte humana e à natureza. Já ultrapassar tal paradoxo não significa retornar à precariedade material anterior ao capitalismo, tal como tem sido pronta e convenientemente alegado; mas, engendrar alteridade de processo cultural-civilizatório, a partir da negação do "nada" (do "não ser" a que tem sido reduzida a gratuidade pelo incontido apropriativismo).

Entretanto, a particularização do sentido comunicativo do intercâmbio já emerge omissa, para não dizer contraproducente, quanto a tal negação, e assim tem permanecido na história da proliferação da espécie humana. Tal omissão se "historiza" em cada um e em todos os indivíduos, sem ultrapassar seu mais radical primitivismo, a coincidir com estágio epistêmico ou autoinsustentável das partes, cujas 
singularidades, por isso mesmo, não se explicam, nem acabam justificadas. Assim, a totalidade humana ainda não se tornou íntegra, porque "incontinuidade-contato", por entre ambos os principais gêneros de componentes do intercâmbio, ainda não é confrontada com o "estar em situação " epistêmica" em relação à perceptibilidade de objetos apropriados e no bojo da escassez criada, nem é assumida como o "ser dialeticidade da razão" por entre o sentido do modo de ser das necessidades e o sentido do modo de ser das funções que as atendem. Esses "não é confrontada" e "nem é assumida" perfazem condição para aventar uma "pequena" narrativa, a respeito da origem e da "historização" das vigentes instituições, indo-se ao encontro do (pós-modernamente admitido) esgotamento da procedência das correspondentes "grandes narrativas", ora sob suspeita de incidirem em meros "fetiches" intelectuais". Ademais, partindo-se desta "fetichização", haveria de permanecer inquestionável que a conquista do poder preceda o privilégio de exercê-lo na gênese da própria dominação.

Quanto a esta precedência, cabe, com apelo a admissíveis verossimilhanças, conjeturar que os primitivos humanos acabaram por se deparar com escassez do que pura e simplesmente apropriar, após proliferarem em espaços onde a vital-fertilidade da natureza lhes era fonte dos melhores e

1 Crise do processo cultural-civilizatório seria aventável como negação da procedência das "grandes narrativas". Em passado longínquo, a emergência do budismo como religiosidade sem deus foi um caso digno de lembrança, diante do alcance mítico do impasse para a ultrapassagem do indiscernimento entre apropriação e produção. $\mathrm{Na}$ atualidade, emergem casos parecidos, a exemplo do "ateísmo cristão" de Luc Ferry (2007) e de André Comte-Sponville (2005), frente à marxiana involuntariedade da inserção nas relações sociais e à consolidação das "injustificações" (desigualdades políticas, das disparidades econômicas e dos desníveis de acesso à tecno-ciência), inclusive entre continentes e ao capricho do individualismo que, por isso ou por complicação da pertinente problemática, não apenas se revigora como ideologia, mas inclusive cria-se áurea de autojustificação. 
mais abundantes meios de vida. Isto sempre significou que suas efetivas referências ou fontes de orientação tenham sido a vital-fertilidade dos corpos das fêmeas, em recorrente e predizível associação com aquela vital-fertilidade da natureza. Ambas essas vitais-fertilidades são espontâneas, materiais e, na pertinente complexidade (ecossistemia, caos e outras propostas de paradigmas), sempre incidiram em heterofagia no nível dos componentes e autofagia enquanto totalidade. Apesar de se dizerem humanos, têm subordinado a tais vitais-fertilidades suas capacidades de pensar, agir e sentir, priorizando, segundo "a lei do menor esforço", aquilo que já esteja pronto, do melhor ao pior. Em decorrência, e desde tempos imemoriais, emergiram desequilíbrios entre necessidades e disponibilidades dos (naturalmente aprontados) meios de vida. Eram desequilíbrios, cujos determinantes, ao início, incidiam em insuficiências do que lhes fosse melhor. Isto houve de induzi-los a disputas. Todavia, as insuficiências tinham como desandar em falta, inclusive do que veio a ser pior, ou mesmo necessário, radical e fatalmente. Então, aquelas disputas tendiam a se tornar fatais e assim tiveram que permanecer, até que, em oásis isolados ou lugares cuja anterior devastação fosse preventiva da presença de novos predadores, alguém se descobrisse capaz de promover a existência de meios de vida, ou mesmo de prevenir até ameaças de que esses meios viessem a faltar. Mas, a condição objetiva da prontidão desses meios continuava a expô-los ao imediatismo de incontidos predadores. Todavia, por serem humanos e mesmo que ainda primitivos, tais predadores acabaram por atinar para a circunstância de que não lhes convinha matar os assim capazes de obter meios de vida. Convinha, sim, arrebatar-lhes uma parte dos resultados que lograssem obter, porém sem prejudicar o necessário para que continuassem exercendo suas capacidades e seu "gosto pela vida", este, tão originário, 
quanto o horror a morrer. Dentro de certos limites, ampliar essa parte arrebatada teria como induzir a que os assim capacitados se tornassem mais produtivos, pois a situação era tal que a única saída possível teria sido aquela de gerarem resultados sempre maiores do que aqueles que lhes tocassem. Então, o próprio predador haveria de se dar conta de que, por força da sua intervenção - estressante, antes de tudo o mais, a ele mesmo e às suas vítimas - teria havido um aumento do exercício das capacidades e dos resultados. Ele próprio passaria a se entender como fonte de referências. E estas, ao serem impingidas, lhe criariam a convicção de serem imprescindíveis, inclusive por ele dispor de meios para evitar que outros predadores ousassem invadir seus domínios, ou mesmo, que constituíssem mera ameaça de tal invasão. Ademais, conviria contar com auxiliares em tais atividades, desde que estes houvessem demonstrado eficiência e jamais viessem a ameaçá-lo, individual ou coletivamente. Tal pactuação entre (um originariamente verossímil) predador-mor e seus cúmplices ter-se-ia "historizado", desde então, em uma institucionalidade (hoje, constituição) pela qual a divisão dos potenciais oponentes garanta que o poder se consolide e se mantenha. Enfim, não seria estranho que, já em seu imemorial primitivismo ou nas suas plurais e recorrentes "historizações", os seres humanos tenham deixado de seguir referências natural-originalmente significativas, apesar de que eles já nasçam com ao menos o potencial de se desenvolverem também em sentido produtivo; especificamente, no sentido de toda pessoa associar sua inata vital-fertilidade àquela que é inerente à natureza.

Eventual sucesso de um tal modelo de sociedade teria possibilitado que a população se expandisse e que aparecessem pessoas em situação díspar no contexto dos próprios vitimados por predação. Ter-se-ia então estabelecido favorabilidade de condições para os mais assim vitimados padecerem 
exploração por parte dos menos vitimados que, por sua vez, teriam tido como se valerem dessas mesmas condições para impingirem a geração de excedentes destinados ao predadormor e a seus prepostos, assim como para quem os explorasse. Enfim, o indubitável produzir teria acabado na hodierna humildade dos extremamente mais vitimados no processo apropriativo, este enquanto organização de todos os predadores, pouco ou nada importando se efetivos (algozes) ou apenas desejosos (vítimas). Mas, limites têm sido inevitáveis, seja à gratuidade, seja à pertinente obtenção. Produtividade nesta obtenção, mediante apoio científico-técnico, torna-se injustificada e injustificante, pela circunstância de esta obtenção só acontecer de antemão e totalmente apropriada, o que implica em incontavelmente mais problemas do que soluções. É que propriedades significam, aos seus detentores, maior probabilidade de acesso a meios de vida, coincidindo com objetos de desejo já realizado. Por sua vez, a incontinência deste desejo faz os objetos apropriáveis se tornarem infinitamente escassos e, como tais, expostos a infindáveis disputas, assim como a recorrentes e sempre mais custosas defesas. Os meios absorvidos no enfrentamento de tais disputas e defesas sempre tiveram como corresponder a meros desperdícios, que são até alargados pela sustentação das instituições voltadas para tal enfrentamento. A insustentabilidade coletiva já é visível em um horizonte em que os conflitos civis passam a substituir as guerras do passado. Disputar e defender propriedades, mesmo que aquelas de estritos direitos, sempre tenderam a usurpar os conteúdos e até o sentido do que propriamente seja educar.

A sustentação dos prepostos do poder sempre jogou papel decisivo na interdependência entre possuidores e despossuídos, o que fez com que esta mesma interdependência se perpetuasse. Mudam esses prepostos, porém não muda a escassez de suportes de poder. Trata-se de escassez que se tornou infinita, 
assumindo o modo "privacional" (vazio, imaterial e não sensorial) como existe a "escassez criada", em radical oposição àquele "presencial" (sensorial, material e plenista) como existem as propriedades que, por mais que sejam expandidas, jamais deixam de ser finitas ou insuficientes. E a dialeticidade que perfaz tal oposição tem como ser abstraída no pensamento e, nesta condição, desdobrar-se em quatro hipóteses: (a) a dinâmica do desejo é real-concreto cuja inerente dialeticidade é apreensível e a própria apreensão incide em inequívoco (auto)-produzir intelectual; (b) dessa apreensão resulta a identidade do modo "privacional" como existe a "escassez criada", identidade que assegura procedência à lógica formal por ter sido, apesar disto ainda ser irreconhecível, a única à qual tem correspondido fundamento real-concretamente inequívoco; (c) quanto ao que acarreta alcance negativo da qualidade em assuntos humanos (dialética do mal), a relação entre perceptível objeto apropriado e "escassez criada" subsiste como via de acesso ao autoconhecimento e ao heteroconhecimento; e, (d) em antítese a esse alcance negativo da qualidade em assuntos humanos, chega-se a alternativas de instituições (fontes de forçosa atribuição de obrigações, a serem inescapavelmente cumpridas por só emergirem no bojo da propriedade) e, por ousado e modesto que o tenha de se "historicizar" (dialética do bem), à "alteridade institucional” (à geração de excedentes de utilidades, fora da propriedade de quem os gera).

A seguir, essas quatro hipóteses se tornam referências de alcance mediativo-dialético. São referências que facultam inferir, às costas ou em ponto cego das alternativas institucionais, o modo "ausencial" como convergem, entre si, os sentidos da exsurgência de necessidades e do exercício de funções para as atender. É inevitável que este sentido e aquela exsurgência guardem, entre si, "incontinuidade-contato" a se desvelar como "razão por entre sentidos" ou como "radicalidade 
dialética de um determinado real-concreto humanizador". Para tanto, o ser humano há de dialetizar-se (conceber-se) por entre apropriar e produzir, ambos e entre si radicalmente desequivocados.

Para deflagrar essa autoconcepção, não seria descabido difundir, entre jovens, a questão de virem a se tornar parcialmente gratuitos em suas atividades e de que é desta conduta que lhes advirão os meios de se sustentarem ou de assumirem adultez. Trata-se de difusão que, diversamente de outras, haverá como futuramente ser explicada e justificada, à base de "dialeticidade da razão" que acabará por deparar-se com a procedente diferença entre apropriar e produzir. À luz dessa razão, também material, será evidenciado que o esforço despendido fora de toda propriedade teria como ser diminuído em uma dominante proporção ou facultaria bem-estar várias vezes maior.

$\mathrm{Na}$ atualidade, o ingresso na educação universitária é o momento mais propício para experienciar "autodialetização" (concepção da própria individualidade, inequívoca e opcionalmente empreendida), ao menos enquanto "rito de passagem".

Todavia, em um mundo do trabalho que se "historiza" no inescapável bojo da propriedade, mediado por competição ou por "criação de escassez", resta óbvio que tal experienciação seja imediatistamente pré-conceituada como disfuncional até a mera sobrevivência.

Nas antípodas de tal disfuncionalidade, certeza sobre a construção do absurdo, em contraponto ao desafio de exercer atividades parcialmente gratuitas, há de gerar tranquilidade e segurança na intimidade da pessoa que passará a entender, em bases real-concretamente fundamentadas, porque têm 
persistido as injustificações das desigualdades políticas, das disparidades econômicas e dos desníveis de acesso à tecnociência. A par disso, torna-se questão, inclusive de sanidade mental, extirpar ilusões, mediante autoconvencimento sobre o que seja algo inequivocamente ético. Todavia, se o próprio processo cultural-civilizatório tem subsistido até o presente, não há de significar "o fim do mundo" conviver com ilusões, ou mesmo admitir que pessoas façam questão de permanecerem iludidas.

Já a contraposição entre construir o absurdo e exercer atividades parcialmente gratuitas facultará ao indivíduo ficar atento às brechas, poros e interstícios, a cujo acesso o "intercâmbio material-comunicativo" tem como ser favorável, para neles instalar um "fractal" de mudança na devida via "críticoteoricamente" emancipatória. Saberá que o ponto certo para instalar esse "fractal" será um espaço ocupacional em que seja ao menos prudente reduzir o absurdo de se ter que pagar sempre mais para produzir. Para tanto, não importa o tipo de ocupação, pois o que está em foco é a fragilidade de quem se ocupa de modo parcialmente gratuito, fragilidade que carece de inusitada mudança institucional para ser protegida.

Em ambiências educacionais, cumpre reconhecer que chegar a tal mudança institucional é desafio que adentra o dilema segundo o qual, ou é despertada a imprescindível competência política no miolo da competência pedagógica ou incompetência pedagógica há de permanecer no bojo da incompetência política. Ademais, não perder de vista a contraposição em causa significará adentrar (o já acima mencionado) "ínferoreferencial" (situação de certezas básicas e inarredáveis, tão duradouras quanto a própria espécie humana), cuja mediação há de coincidir com inusitado congraçamento entre educadores, tendendo a implodir competição na interioridade da 
ambiência educativa, sem prejuízo, antes o contrário, à dinamização das atividades em geral. Profissionais da educação, uma vez assim situados, hão de propender ao reconhecimento de que se deparam com um novel dilema entre serem partícipes do que só teria que dar certo, ou então, assumir, de vez, que toda competição tem dois lados, dos quais o indesejável nem sempre coincidirá apenas com aquele do (tido por) perdedor.

\section{Projeto político-pedagógico}

\section{Projeto enquanto opção inerente à própria concepção}

Projeto é concepção em duplo alcance, por constituir uma formulação, o que é até truístico e, por esta mesma formulação, corresponder a conteúdos que ainda devem se tornar realidade. Assim, o que cabe considerar é a determinação - ato político - dos seus possíveis conteúdos. No caso de estes conteúdos serem pedagógicos, tem-se em conta que tal determinação já emerge circunscrita a um campo de atuação humana e em menor abrangência do que a totalidade deste mesmo campo. Contudo, mesmo que assim circunscrito, o ato político não tem como acabar dispensado de ocorrer enquanto escolhas destes ou daqueles conteúdos da própria pedagogia.

Chega-se, assim, ao que caberia admitir como carência de emancipação da pedagogia, no sentido da necessidade de ela própria não mais deter flancos escancarados à fragmentação que é própria dos objetos de conhecimento, a começar pela multiplicidade de concepções de ser humano e sociedade. 
Por inusitado que o tenha que ser, buscar essa emancipação precisa constituir objetivo primeiro e último de um projeto político-pedagógico. Para tanto, os atos políticos de escolha hão de concretizar-se como atuações que, por sua vez, terão como perfazer pedagogia na situação de "incontinuidade-contato" por entre os dois sentidos do modo de ser "ausencial" de como humanizar, ou seja, por entre o sentido da exurgência de necessidades natural-básicas e o sentido do exercício de funções para as atender em reciprocidade de coerência com intercâmbio orgânico em relação direta ou indireta com a natureza.

No contexto político-educacional vigente, esses sentidos não contam com suas próprias diferenças, pois ainda se "historizam" insuficientemente livres as atuações nas quais ocorrem, vale dizer, escolhas, enquanto relações sociais, não acontecem suficientemente mediadas pelo discernimento entre opção e imposição. $\mathrm{Na}$ ausência de tal mediação, o significado atribuído ao que seja pedagógico torna-se problemático, por necessitar e não dispor de especificidade a toda a prova, especificidade cuja ausência seja consentânea com compreensão dos seus conteúdos na hegemônica condição de estritas práticas didáticas. Trata-se de condição que, por sua própria forma, exclui "incontinuidade-contato" por entre os sentidos de humana e de humanizante dessas suas práticas.

Paralelamente a essa exclusão e ao menos em alcance hipotético, eventuais crises da pedagogia seriam respostas à circunstância de as práticas didáticas não terem como se "historizar" senão à base de conteúdos que vêm sendo ideologizados para que não se evidencie a sua imposição. Saída assim ideológica - que previna tal evidenciação - reside na conduta de sobre-estar narrativas de saberes, cujos fundamentos ou correspondentes reais-concretos somente provenham 
do exterior do educando, peculiarmente se admitidos como reais-concretos humanos. Trata-se de conduta que tem como presumir velada pretensão de que os objetos narrados se tornem universais, mesmo que situados e, com isto, a universalidade da sua imposição tenha como culturalmente se consolidar.

Nesse contexto, encarar a problematicidade das atuações incide em ato político que, por hipotético que precise ainda subsistir, há de acontecer com o caráter ético de "apear da perceptibilidade de objetos apropriados" (deixar de apoiar-se tão somente em objetos externos à pessoa e cuja perceptibilidade os faça serem válidos de forma inconteste) e passar a se perceber na "incontinuidade-contato" por entre, de um lado, o modo plenista, sensorial ou material como existem os objetos apropriados, e de outro, o modo vacual, imaterial ou não sensorial como existe a escassez que é criada à conta de desejos não realizados ou irrealizáveis. Trata-se de perceber "formação" cuja real-concreticidade seja inequivocamente específica, ou seja, que se evidencie mediante radicalidade dialética na oposição entre a identidade a toda prova do modo de existir da "escassez criada" e as diferenças pelas quais dá-se a conhecer o modo de existir dos objetos apropriados. Por isso, cumpre entender que identidade a toda prova ainda há de acabar evidenciada como fundamento primeiro e último da lógica formal, tornando-se imprescindível a toda concepção ou formulação.

Todavia, o perceptível modo de existir dos objetos apropriados, em cuja presença há realização ou repouso de correspondentes desejos ou interesses, não se traduz em suficiente garantia para que esse mesmo repouso seja definitivo. Assim, à conta dessa insuficiência, aqueles objetos não têm deixado de estar sob ilimitável expansão e/ou transformação. Já ameaça de expropriações, basicamente de tudo o que direta 
ou indiretamente venha a garantir o atendimento da necessidade culturalmente criada de estarem de antemão satisfeitas as natural-básicas, faz com que, finalmente, possuidores e/ ou interessados em assim se garantirem percebam aquele alcance vacual, imaterial e não sensorial do modo de existir da "escassez criada", atingindo autoconhecimento e abertura a heteroconhecimento.

Obviamente, o ato político correspondente a "apear da perceptibilidade de objetos apropriados" ainda não ultrapassa gestos de renúncia a propriedades estritamente pessoais, o que ocorre, em rigor, sem razão que os explique e a própria renúncia seja justificada. Tais gestos têm desandado em autoentrega a propriedades comunitariamente administradas, de forma justaposta ou mesmo contraposta às de outrem indivíduos, famílias, ou mesmo, outras comunidades. Max Weber (1982, p. 380-381) argumenta que tais gestos acabam contraditórios, pois a renúncia deixa de fazer sentido à conta de criação de riqueza. Além disso, o próprio Weber (1983, p. 4) assume explicitamente que, em "toda espécie e condições de pessoas", existiu e existe "impulso para o ganho" ou "ânsia de lucro". Todavia, interessado em "fenômenos culturais dotados de um desenvolvimento universal em seu valor e significado" (grifo no original), exclusivos da Civilização Ocidental, esse sociólogo clássico dispensa-se de considerar, ao menos no tópico em questão, a problemática de que aquelas criações de riqueza têm ocorrido, em todo tempo e lugar, alheias à parcial e imprescindivel gratuidade das fontes dos meios de vida. Se injustificações continuavam a ocorrer, inclusive no contexto doméstico do mais ideal-típico Ocidente, no exterior deste, elas estavam em franca dinamização, inclusive em alcance continental (notoriamente, na África, na América Latina e no Sul-Suleste da Ásia). 
Assim, conteúdos pedagógicos em sentido humanizador precisam ser buscados no âmago do que tem sido preterido, quer dizer, no bojo da condição marginalizada, informalizada e sócio-subjetivada, no qual tem acontecido a "relação entre prole e quem, direta ou indiretamente, a sustenta”. A reprodução da espécie responderia a meros instintos feminis ainda incontroláveis, deixando constante margem à interpretação de que todos já nascem "demais", tendo que competir por "um lugar ao sol" (propriedades autoincludentes e heteroexcludentes). Competição não seria fenômeno propriamente cultural, mas premência inata e inalienável, o que explicaria e justificaria as instituições vigentes e pertinente ônus sustentatório. Por terem de ocorrer no bojo da propriedade, existiriam, no máximo, alternativas a essas instituições. "Alteridade institucional" sequer tem entrado em cogitação, pois, nem mesmo esta cogitação teria como ocorrer fora da propriedade, vale dizer, ocorrer como gratuidade vital-fértil que é efetiva na natureza livre e ainda meramente potencial na humana (tida por) adulta.

Dar-se conta da gratuidade, no âmbito da relação entre prole e quem a sustenta, há de incidir no embrião da "historicidade" da razão dialética, daquela ainda a se situar no modo de ser "ausencial" (imperceptível) como convergem os sentidos do mover-se das necessidades e do mover-se das funções de as atender.

Com efeito, faz sentido valorizar, a despeito da ameaça de continuar a prevalecer o contrário nas relações sociais, o inevitável esvair-se das energias corpóreas, desde que tal inevitabilidade seja voluntariamente assumida como oportunidade de a pessoa se dar a própria existência, mediante avisada e prudente conversão daquelas mesmas energias em funções que se voltem para atender necessidades, a começar pelas natural-básicas, pessoais e da espécie. 
Ademais, à base do dar-se conta da gratuidade, evoca-se o que urge ser entendido como "crítico-teoria", ou seja, como evidenciação de que as instituições sempre se "historizaram" seguindo a estratégia de canalizar tal geração da gratuidade para possuidores das respectivas fontes, estratégia que se dá a conhecer pela criação de condições (propriedades externas à pessoa e ilimitadamente garantidas), as quais têm servido para separar, entre si, a exsurgência das necessidades e o exercício das funções para as atender. É essa separação, culturalmente criada, o que explica e injustifica essas propriedades.

À luz dessa "historização" das instituições, resta cristalinamente evidenciável que a gratuidade e sua efetiva fonte adentrem a mais extremada das fragilidades. Por isso, há de restar, também assim frágil, a autoafirmação de conteúdos pedagógicos, tanto humanos quanto humanizantes. Mas, proteger tal escolha incidiria em "alteridade institucional", ainda que em alcance apenas "menos negativo" (com menor ônus sustentatório).

Em decorrência, e na presença daquela autoafirmação pedagógica, um projeto político-pedagógico teria como visar tal proteção, sem que esta, para subsistir, tenha que ser invasora da oportunidade de gerenciar "impulsão para o ganho".

\section{Sentido propositivo-pedagógico de transitar por entre política e ética}

Extemporaneidade usurpadora da relação entre prole ainda naturalmente autoinsustentável e quem a sustenta tem sido culturalmente reproduzida, para não dizer salva, por força da (inercialmente exercida e convenientemente irreconhecível) relação entre dominação política e exterioridade (à pessoa) dos objetos apropriados. Tal reprodução tem ocorrido 
à conta da incontinência apropriativa que sempre desandou em fortalecimento de poucos e enfraquecimento de muitos. Por sua vez, esse fortalecimento tem ocorrido em alcance como que genético-cultural, cuja inercial prevalência na história tem implicado interdependência entre fortes e fracos. É que os fortes têm transferido para os fracos o enfrentamento da inequivocação quanto a efetivamente produzir. Todavia, tal transferência e privilegiada distância desse enfrentamento, além de se equivalerem, têm implicado omissão educacional. Já esta omissão tem correspondido a não compensar redução da natural-finita autoinsustentabilidade juvenil por capacitação adulta a se autossustentar em reciprocidade de coerência com a coletividade e com o intercâmbio orgânico em relação direta ou indireta com a natureza.

A princípio, cabe afirmar que padecimento da sustentação alheia pelos despossuídos de fontes de meios de vida e transferência da sustentação própria pelos possuidores têm sido gestos antieticamente políticos e sempre careceram de uma inversão dialética que os transmute em antipoliticamente éticos, vale dizer, em universal enfrentamento da sustentação própria, assim como da prole ainda disto incapaz e do soerguimento das condições para existir a coletividade em que tal inversão se reproduza incessantemente.

\section{a) Da política à ética}

A exemplo do que já ocorre desde tempos imemoriais, peculiarmente do que acontecia ao longo da Antiguidade Clássica, tem coincidido com dominação política o modo de vida cuja dinâmica presume excedentes de alimentos gerados no exterior das cidades. Em rigor, a geração desses excedentes tinha e ainda tem por contrapartida a prestação de garantias a direitos de propriedade sobre os resultados do 
trabalho alheio. Já estes resultados vêm sendo obtidos à conta de potencial ou efetiva exclusão do acesso à propriedade das fontes de meios de vida - da própria corporeidade (no caso de escravos) e dos recursos naturais. Ao longo da história, gratuidade de capazes de produzir tem sido imprescindível ou institucional. Por ocorrer tão só no interior da propriedade, ela há de destinar-se a outrem que não seja a sua própria fonte, enquanto a pertinente geração também há de ser forçosamente impingida. Neste caso, sua imprescindibilidade está usurpada e seu caráter institucional é alternativo, pois, à medida que ninguém a gera opcionalmente, resta explicada a pertinente imposição, além de apenas ideologicamente justificado o alcance improdutivo do trabalho correspondente àquele de impingi-la.

Todavia, caso fosse possível saber que gratuidade opcionalmente gerada signifique não mais ser explicável sua imposição e acabe por injustificar o alcance improdutivo do trabalho de impingi-la, então os (enfim) sábios se deparariam com "alteridade institucional", no sentido de que a imprescindibilidade de serem gratuitos explique a singularidade pessoal por sua relação com a coletividade e a suficiência desta justifique tal singularidade. Neste caso, os beneficiários teriam que ser crianças e/ou pessoas incapazes de autossustentação, assim como o soerguimento de radicalmente inovadas condições da existência da coletividade.

Na histórica vigência do alcance alternativo da institucionalidade, negar-se a ser parcialmente gratuito tem desandado em ameaça e efetividade de heteroexclusão por parte de possuidores de fontes objetivas de meios de vida, por força da recorrente e implacável ameaça de os despossuídos de tais fontes não terem como acabar beneficiários de resultados do processo produtivo. Este desfecho tem evocado o medo 
da privação, inclusive extrema, insuflando-se o instinto de preservação. Assim, a necessidade de remediar e de prevenir tal privação passa a favorecer estratégias de impor geração de gratuidade aos despossuídos. Trata-se de seguir difusas estratégias político-dominativas, as quais sempre implicaram capacitações para perceber, observar, interpretar e conceituar o potencial e/ou a efetividade de esforço produtivo, porém, tão somente no exterior de si mesmo e no interior das propriedades dos próprios estrategistas. Por sua vez, essas capacitações têm incidido em fenômenos pedagógico-epistemológicos, dos quais derivam insuficiências, ou mesmo ausências, dos presumidos esforços gratuitos, implicando, da parte dos incapacitados, esforços gratuitos maiores do que os justificáveis, ou seja, do que os inequivocamente devidos.

Cabe, então, questionar a recorrência da falta de uma conceituação de injustiça, cujo fundamento real-concreto coincida com a renitente omissão quanto a se comprometer com a devida gratuidade do esforço próprio e com o indevido excesso do esforço alheio. E a resposta há de incidir na inferência de que essa omissão quanto a se comprometer denote falta de autoconhecimento enquanto fonte de dominação política.

A respeito de tal recorrência, resta ao menos admissível que os remotos antecessores do pensar hoje denominado epistemológico (os pais da nova paideia clássico-antiga: filósofos, legisladores e mercadores) passaram a exercer dominação política contra as fontes da mitologia (os pais da velha paideia: sacerdotes, reis antigos e poetas). Entrementes, na história da pessoa singular, tal passagem é recorrente, pois, insuficiência ou mesmo falta total de gratuidade, na esfera desta história, tem desandado em incontrolável "criação de escassez" de espaço vital, a partir de difusos e localizados esgotamentos e/ 
ou "cercamentos" da gratuidade provinda de fontes naturallivres, estas sob acentuada pressão para contrarrestarem com ilimitados aumentos de produtividade. Mediante tal "criação de escassez", a político-dominativa transferência da geração de gratuidade de fonte própria para fonte alheia sempre precisou ocorrer com o apoio de potencial ou efetiva epistemologia, vale dizer, mediada por concretos de pensamento, aos quais correspondem reais-concretos humanamente objetivos - pessoas inequivocamente produtivas, inclusive por insuficiência ou mesmo falta de acesso à própria epistemologia.

Com efeito, significam autodenegações de se tornarem fontes de gratuidade os atos de perceber, observar, interpretar e conceituar reais-concretos apenas transcendentes às pessoas que assim atuam, inclusive os reais-concretos correspondentes a estas mesmas pessoas. Ocorrem tais autodenegações, porque a imprescindibilidade de a pessoa se tornar parcialmente gratuita se encontra liminarmente marginalizada, informalizada e sócio-subjetivada, apesar, ou por conveniência político-dominativa, de se constituir na fundante contraparte de tributos e demais lucros, a decorrerem de (também político-dominativamente criados) direitos de estrita propriedade sobre resultados da produção.

A via de marginalizar, informalizar e sócio-subjetivar a geração de gratuidade, a começar pela pessoal, desanda em obsessão por excedentes que, em decorrência, acabam de antemão justificados, para não dizer que se autoimpõem sob fetichização da produtividade.

A via, em foco, tem estado escondida sob proporção do preço final dos bens e serviços, os quais, para tanto, precisam ser levados a mercado. Neste, o ato político da anuência a contratos de compra e venda, característica de cada uma e de todas as transações, difunde-se e se perpetua, transformando 
conjunturas sincrônico-topocêntricas (ao mesmo tempo e, de preferência, em um único lugar) na estrutura diacrônicotopocêntrica (em épocas sucessivas e, de preferência, em um único lugar) das acumulações de propriedades disparmente acessadas. Porém, é dessas acumulações de propriedade que emana o critério de acesso aos resultados da produção, ou seja, ao sempre mais predominante alcance artificial dos reais-concretos, estes com origem em significantes (pseudo)fundamentais. E é assim que também emana a crescente proporção de tributos e demais direitos de estrita propriedade, proporção que ocorre embutida nos preços monetizados dos meios de trabalho. Já estes meios, que também perfazem aqueles mesmos resultados, desandam em suporte procedimental para a criação do absurdo de se ter que, sempre mais, "pagar para produzir", vale dizer, tornar-se vítima da mais decisiva causa da exclusão social.

Assim, as pessoas que dependem de produzir para acessar resultados, inclusive das próprias atividades, prefeririam também se ocupar com impingir e usar tributos e demais lucros, os quais são criados como direitos a se transformarem em propriedade. Já criação de direitos incide em ato políticodominativo a desandar em "arrogância reivindicalista".

A urgência em obter excedentes sempre mais amplos pressiona por avanços científico-tecnológicos em ciências naturais e em automação, apontando para uma relação direta entre desumanização e depredação da natureza, pelo menos enquanto persistir a político-dominativa insistência em ideologizar desumanização e depredação como se fossem os pertinentes inversos (humanização e produção). Neste caso, ficará ainda mais fenomenicamente oculta a circunstância de que escolha - ato político - de objetos de saber precede ciên- 
cias e estas jamais tenham sido neutras, ainda que reduzidas a estritos instrumentos.

Em perspectiva "crítico-teórica", sempre houve coincidência entre, de um flanco, a incapacidade de a própria pessoa se descobrir e se efetivar fonte de gratuidade e, de outro, o alcance epistemológico da racionalidade em cujas implicações o jugo patronal se torna individualisticamente "menos pior" do que o jugo das necessidades. Já o sentido de "menos pior" adentra valor e, por isso, responde à ética, inclusive enquanto pretexto para perpetuar a moderna vitória da burguesia em bastidores pouco ou nada sondados do individualismo sustentatório, a se refugiar por trás de biombos empresariais e até institucionais.

Quanto ao caráter epistemológico da racionalidade, é imperativo considerar que a condicionalidade da originária "situação epistêmica" tem como acabar reforçada pelo "gosto de viver", ou seja, pelo alcance prazeroso do atendimento das necessidades próprias, a começar por aquelas de contar com a familiaridade do esforço de outrem, isto é, com o que é estrita e endogenamente vivenciado desde a concepção. Trata-se de atendimento que se esgota naturalmente, emergindo contradição como concreto de pensamento a corresponder ao contraditório real-concreto entre escassez potencial ou efetiva e disponibilidade efetiva ou potencial. Escassez há de advir do subjetivo para o objetivo e à conta de desconforto, peculiarmente insegurança subsistencial, enquanto disponibilidade terá de provir do objetivo para o subjetivo e de coincidir com o restabelecimento do conforto, graças a doações, aquisições ou mesmo conquistas. Por sua vez, ao não ter como provir do "gosto de viver", o esforço tem implicado em um recorrente e predizível retardamento cultural - não natural - da percepção do contraditório entre 
escassez e disponibilidade, incidindo-se na propensão pela qual a faculdade de se impulsionar (intencionar-se) e a de racionalizar (relacionar idealmente) se autoentregam a nada mais do que ao atendimento das necessidades próprias, às custas de prévia prontidão dos meios a tanto imprescindíveis e disponibilizados por outrem.

Tal racionalidade tinha que usurpar o espaço da razão em si mesma, ou seja, daquela que confronte, entre si, "criação de escassez" e disponibilidade, além de dialetizá-las genética e genericamente e, com isto, produzir em sentido intelectualinquívoco.

Quanto às implicações epistemológico-racionais de o jugo patronal se tornar "menos pior" do que o jugo das necessidades, elas se desvelam como criação de valores predominantes, segundo três estratos: (a) hedonismo - valoração pela qual o "gosto de viver" desanda em obsessão pelo estritamente prazeroso e, com isso, conserva o contraditório à superfície da realidade, reduzindo-o a falsas dicotomias e destinando o sentido produtivo da dialeticidade para uma "pseudo-transcendência" (princípios ou leis evolutivas; "mão invisível do mercado"; apriorística autonegação da gratuidade humana); (b) fechamento racionalista às relações entre meios e fins - valoração que adentra visões de mundo de conotação excludentemente sistêmica; e (c) material ou subsistencial - obsessão pelo estrito atendimento das necessidades próprias e históricoculturalmente criadas (nunca foram valoradas as necessidades por si mesmas), de forma que acabe inadmissível que seja diretamente assumido o atendimento das necessidades vital-básicas próprias, mas deixado para trás, em uma condição tirante a “aquencendência" (por aquém do próprio "não ser”).

Valores predominantes traduzem éticas que estão descoladas de um produzir dialético, pelo qual o indivíduo se 
descobriria singular e se aperceberia da sua relação com as fontes dos meios de atendimento das próprias e vital-básicas necessidades. E, dada a ausência deste indivíduo, sempre houve como coincidirem ética e política, para não dizer que ambas jamais se tenham diferenciado. É que, sem disponibilizada contrapartida subjetiva em idear, intencionar e aprontar meios de vida, sempre houve que ocorrer inevitável e objetiva escassez da imediata presença desses meios, na perspectiva da melhor para a pior prontidão. Cria-se, em decorrência, antagonismo entre interesses para acessar a melhor prontidão e, à conta de "acessar antes" (chegar primeiro), o real-concreto da incontinência apropriativa. Sucesso de uns em assim apropriar desanda em insucesso de outros para "chegarem primeiro" ao prontamente melhor, depois ao que é "menos melhor", a seguir ao necessário, até que o acesso ao imprescindível adentra o dilema entre disputar - criar o antagônico - ou perecer. É o que caracteriza o fenômeno político: vitória ou derrota, de tal forma que, na derrota, cumpre construir a vitória e, na vitória, cumpre prevenir a derrota - a paz implica a guerra por antecipação. Sucesso, por vezo de origem, é não universalizável e, todavia, solitariamente descabido. Ademais, buscar sucesso tornou-se arriscado e, sobretudo, esfalfante, convindo autoentrega à instintividade de atribuir a outrem o inequívoco ônus de chegar até ele e de concentrar, preferencialmente em si mesmo como único beneficiário, o acesso aos resultados, inclusive como alternativa de hierarquizar interesses. Em desfecho, valoração sincreticamente hedonista, racionalista e materialista é presumida à substituição do jugo das necessidades por outro, desde aquele de conotação hierárquica (caso das castas indianas), passando pelo alcance coercitivo-estatista (caso da cidadania na "pólis" helênica) e chegando ao vezo político-epistemológico-econômico (caso das modernas relações sociais). 
Historicamente, a vitória da burguesia tem evitado sua própria derrota pela racionalidade sistêmica de promover alianças em duas frentes, às quais é comum a valoração ao mesmo tempo materialista e hedonista do "gosto de viver": (a) cumpre extirpar as oportunidades de aprender a produzir no âmbito familiar, microempresarial e comunitário, estimulando-se a preferência pela renda nominal-monetarizada em dicotomia com acentuado descrédito da renda real-concreta; e, (b) criam-se oportunidades de os prepostos do poder regulamentar-político endividarem o Estado para atender demandas sociais em franca inchação, o que pressiona o aumento da carga tributária e da margem de rendas privadas líquidas; estrategicamente, da margem que incide sobre serviços de dívidas públicas, precipitando-se, não só o imperativo de pagar sempre mais para se ter acesso a ocupações formalmente remuneradas, como também a competição precipitadora de interesses individualistas em busca de imprescindível saída (auto)-sustentatória.

É na trama daquela preservação da vitória da burguesia que urge entender a transformação da escola em departamento a dar conta da especialidade de promover valoração do "gosto de viver", a par da capacitação para a cidadania confundida com "arrogância reivindicalista", ambas - valoração e capacitação - socialmente funcionais ao incremento de tributos e/ ou do endividamento do Estado. Para tanto, há de acabar de antemão preterido o contraditório entre o permanecer no que é familiar (no "gosto de viver") e adentrar estranheza (participar de um processo de produção cuja dinâmica implica renúncia à inconfessa melhor parte dos imprescindíveis resultados). É em tal contraditório que se configura a tendência à metropolização do modo político ou antiético de conviver. Cria-se uma realidade em que a imprescindível sustentação pessoal se torna acentuadamente privilégio, à medida que 
direitos se tornam propriedade a se reconcentrar, graças à garantia conferida à propriedade exterior à pessoa, ou seja, ao "norte" sistêmico.

Entretanto, universalizar (democratizar) acesso à propriedade não tem como incidir em questão de direito, pois feriria, custosa ou proibitivamente, interesses vitoriosos e, como tais, transformados na propriedade de direitos. Com efeito, remediar conflitos apropriativos tem implicado a própria e onerosa existência das instituições e, por isso, inexiste algo de mais custoso do que a contestação da propriedade, sobremaneira aquela de direitos. Ademais, a recorrente remediação de conflitos contestatórios da propriedade de direitos tem incidido, prévia e calculadamente, no impingimento à produção de acentuada produtividade e isto, ao presumir ilimitação de excedentes, não passa de saída cuja enigmática teleologia permanece inacessível aos (próprios e elitistas) beneficiários.

Em desfecho, apropriação privilegiada se torna tão imprescindível quanto a produção mesma, o que implica estimular retornos privados líquidos como requisito, também imprescindível, para que tributos sejam gerados.

$\mathrm{Na}$ modernidade ora vivenciada, a história pessoal continua totalmente à mercê do epistemologismo, cujo reflexo tem estado no político-dominativo apelo a avanços em ciência e tecnologia, na (ainda irreconhecível e ilusória) pressuposição de que, para vitoriosos inclusive, não sobrevenha o "inferno" (abundância da escassez criada, a coincidir com gratuidade negada, apesar de o real-concreto da própria gratuidade se constituir na imprescindível contrapartida dos componentes da mais-valia - tributos e rendas privadas líquidas). Em desfecho, política tende a desandar em antiética "arrogância 
reivindicalista", peculiarmente ao se tentar democratização do pertinente exercício.

\section{b) Da ética à política}

A emergência do contraditório conflituoso presume a escassez que, por sua vez, é criada pela incapacidade de a pessoa descobrir-se e se efetivar fonte de imprescindível gratuidade. O efetivo alcance humano da situação dessa pessoa é aquele de incapacidade de obrigações (antieticidade) ou de inescapável cessão parcial da capacidade própria de direitos (heterocondicionamento político).

Já a "criação de escassez" coincide com efetiva e/ou desejada autonegação da gratuidade de fonte própria nas relações sociais de produção, negação cuja efetividade procede de precoce anuência a valores na esfera da subjetividade e é inercializada como fenômeno sociocorporativo. Inferência de tal efetividade presume recurso à dialética que perfaz a dinâmica do desejo, uma vez que o caráter coletivamente imprescindível da geração de gratuidade tem sido cultural-institucionalmente atribuído aos mais fracos e estes jamais deixaram de almejar a situação oposta. Por isso, e se os atores em jogo forem adultos capazes, a dicotomia fraco-forte há de compreender contato, ou mesmo intercessão, dos contrários. Em tal jogo, ninguém é suficientemente forte que previna toda ameaça de assalto às propriedades extrínsecas a própria pessoa. Da mesma forma, nunca se é tão fraco que não seja possível exercer funções em algum proveito próprio.

Na perspectiva de que é inevitável enfrentar o jugo da necessidade e na anuência à "sujeitação" (preferência pela relação patrão-empregado), a experiência da involuntária produção inequívoca não faculta intuir a "situação diastêmica" (situação mediativo-dialética) da pessoa por entre as 
abstrações correspondentes à prole e a quem 'sustenta. Nesta "diastemia", ao contrário do que ocorre naquela "sujeitação", a espécie será perpetuada à conta de relações entre espécimes que, por sua vez, hão de explicar-se como fonte da gratuidade que é absolutamente imprescindível à prole e serão justificados pela suficiência das condições de perpetuação da espécie da qual procedem. Explicação e justificação da pessoa singular hão de ocorrer em bases "sincrônico-topomúltiplas" (ao mesmo tempo e em muitos lugares) e "diacrônico-topoúnicas" (em tempos sucessivos e em um mesmo lugar, vale dizer, em bases que precisam caracterizar o modo urbano de convivência). Escassez terá como ser prevenida; porém em acordo com limitações que são naturais ao sentido inequívoco e opcionalmente empreendido do produzir.

Um ainda irreconhecível determinante das limitações do poder e da fraqueza tem emergido na trama das relações sociais implicadas no modo urbano de vida, tendo-se em vista que a ambiência citadina presume "intercâmbio material-comunicativo" em cuja dinâmica sempre surgiram oportunidades de ultrapassagem do "panóptico" controle da produção campesina que não prescinde de um durável e exposto acesso à condição objetiva da terra em que tem seu lugar.

A propósito do esgotamento de tal controle, já as antigas cidades helênicas encontraram precedentes de suas constituições em suas similares no imemorial "berço" (terras adjacentes e águas do Mediterrâneo Oriental) do "intercâmbio materialcomunicativo".

Controlar de modo "panóptico" as relações sociourbanas incidiria em "insustentabilidade coletiva" (em custo proibitivo, por presumir exacerbação de conflitos apropriativos nos contrafortes sociais da obtenção dos meios a tanto imprescindíveis). A avolumação dessas relações veio a ser a principal 
característica da urbanização, que se acentuou com a modernidade. Na história atual, até as atividades rurais já assumiram conotação urbana, na perspectiva de que se tornou impraticável a autossuficiência do pertinente empreendimento.

Em decorrência, a insustentabilidade material do controle social como real-concreto da prática política tende a incidir em insustentabilidade institucional, cujo reflexo é incidência em abertura de espaços democráticos como precedentes da oportunidade para autogoverno - este, a requerer um humanismo de perfil mais universalista no nível da singularidade pessoal.

Todavia, a busca de um tal humanismo resulta inconciliável com o reducionismo tecnicista que está a absorver todo o potencial de aprendizagem da pessoa para que esta se garanta sua mera subsistência, inclusive enquanto partícipe da elite a se esfalfar para manter e ampliar propriedades com as quais chega a até mesmo se confundir. Insuficiência de percepção dessa inconciliabilidade traduz-se na disputa entre maximização do Estado e minimização do Mercado ou inchação deste e minguamento daquele, disputa que houve de ocorrer de forma alheia à emergência de oportunidades emancipatórias a serem assumidas como "ínferos referenciais" de "alteridade institucional", de incondicionamento político, ou ainda, de referenciação ética.

Eticidade se torna historicamente oportuna na acentuação da insustentabilidade institucional. A rigor, ela procede do questionamento das instituições, à medida que estas são apropriadas pelos seus prepostos, o que houve de acabar subsumido nas injustificações que decorrem da forma de obtenção dos meios sustentatórios de tal apropriação, tendo por inescapável desfecho a valoração da sincrônico-topocentria do metropo- 
lismo, a decorrer da involuntária inserção dos sustentadores nas relações sociais, a partir daquelas de produção.

Eticidade e involuntariedade são radicalmente antitéticas. Todavia, eticidade há de emergir consentânea com "alteridade institucional", bem ainda com subjetividade e com emancipação. Assim, para que ética entre em pauta como "assunto socrático", torna-se imprescindível que se questione uma institucionalidade que sempre se impôs de modo topocêntrico, bem como a cumplicidade entre o exclusivismo da objetividade da Ciência, em apontar o que "teria de" fazer história, e o legalismo da Norma, em coibir o que "deveria não" fazer história.

Institucionalidade e eticidade carecem de inequivocação quanto ao que seja "o" imprescindível, pois este facultaria a ambas uma referência comum. Sabe-se, antes de tudo o mais, que "o" imprescindível é a espécie se reproduzir, mediante produção de meios de vida "por aquém" dos requisitos sustentatório-metropolísticos - estes, estritamente individualistas e/ou corporativistas. De fato, este "por aquém" coincide com atitudes (como que) "aquencendentes" à racionalidade precificista e/ou financeirista, esta a se caracterizar por funcionalidade sociológica à obtenção de tributos e demais rendas de estrita propriedade e por disfuncionalidade humana a dar conta da autoinsustentabilidade da prole. Por sua vez, esta prole tem de subsistir mediante excedente de produção a se originar em outrem que, ao prescindir de parte do que lhe pertence por inequívoco mérito, assume gratuidade de parte do seu próprio esforço produtivo ou dos resultados deste. $\mathrm{Na}$ ausência de tal "irracionalidade", a procriação teria de conformar-se a interesses e incidir em contrassenso emancipatório e em sócio-subjetivação sustentatória da prole. Já esta conformação, ao avançar do metropolismo, passa a ser 
fonte de inusitados contraditórios, a começar por aquele de “impositividade de emancipação". Paralelamente, autoinsustentabilidade se transmuta em violência, à conta, não apenas da postergação cultural do seu natural esgotamento à chegada da adultez humana, como também da perda das suas referências moral-culturais.

Em suma, incide-se em situação existencial-pessoal que tende a se traduzir como "estar demais", por implicar competir por um (tácito) absurdo que é inerente à circunstância de a emancipação ser compulsória em vez de opcional ou de a dependência ser livre em vez de involuntária. Trata-se de circunstância que desanda em falta de autenticidade no "intercâmbio material-comunicativo" ("afetividade" apenas nas aparências e a refletir agressividade latente, ou então, agressividade nas aparências a refletir "afetividade" latente). Esse "estar demais" é patogênico, ao transformar o "escapismo" mítico de antanho em "internalizacionismo" alheante (a pessoa tem que existir como "sendo" o que, não importa como, the seja inicialmente inculcado e finalmente por ela mesma buscado, apropriado, conquistado, sequestrado, consumido, conhecido enfim ${ }^{2}$ ), assim como em "apetite" para construir o absurdo, mediante obsessão por estrita prática. Aproxima-se, caso não já estiver efetiva, uma crise de referenciação cuja ultrapassagem requer que a imprescindibilidade

2 A conotação histórico-cultural da pedagogia apontaria para tal "artificialização" da pessoa, à medida que certo psicologismo estaria a intentar engendrar a consciência do ser social. A propósito, cabe reproduzir um excerto de texto de L.S. Vigotsky (FORMOSINHO, KISCHIMOTO E PINAZZA, 2007 apud PIMENTEL, p. 225): “Qualquer função psicológica superior foi externa (e) social antes de ser interna... Todas as funções no desenvolvimento cultural da criança aparecem duas vezes ou em dois planos... Aparecem primeiro entre pessoas como uma categoria intermental (interpsicológica), e depois no interior da criança como uma categoria intramental (intrapsicológica). Isso é igualmente verdadeiro para a atenção voluntária, para a memória lógica e para a formação de conceitos" (grifo nosso). 
de inequivocação quanto a produzir se torne comum ao que é institucional e ao que é ético, incidindo em mediação dialogal-dialética entre ambos.

A rigor, está a emergir uma crise da falta de discernimento entre o restar absurdo do "estar demais" e o fazer sentido do "gosto pela vida". A persistência dessa crise se traduz em uma encruzilhada entre, em uma direção, incondicionalidade política enquanto eticidade não mediada por inequivocação quanto a produzir e, em outra direção, condicionamento político enquanto eticidade mediada por essa mesma inequivocação, questão que se candidata a incidir em "assunto socrático".

Nesta última direção, entraria em questionamento o dilema entre ser ou não ser absurdo "estar demais", a menos que persista uma pertinente autoentrega ao "gosto pela vida", assim como uma conexa inciência. É que emerge, ainda na adolescência, a natural necessidade de emancipação autossustentatória, necessidade que, após a Revolução Industrial, se defronta com sempre mais abrangente impasse resolutivo quanto ao pertinente atendimento, evocando o dilema entre "ser" ou "não ser" absurdo "estar demais". E, na ausência de resposta à altura do pertinente problema, uma eventual e radicalmente "crítico-teórica" percepção do absurdo quanto a "estar demais" tem como desandar em precoce desespero. Caberia, então, questionar: até que ponto seria possível prevenir a percepção do "estar demais"? Qual a influência do "internalizacionismo" dos fatos culturais? Não se estaria a evocar o "estar demais" para precipitar violência juvenil? Seria de antemão descartável a hipótese de que a violência seja ao menos correlata ao "internalizacionismo" que caracteriza a pedagogia colonizada por psicologismo histórico-cultural? 
A propósito de tais questões, seria utópico retornar aos tempos em que a autossustentação se diluía naquela domiciliar e/ou comunitária. Em contraponto, o novel e metropolístico isolamento pessoal, peculiarmente em alcance também autossustentatório, induz à percepção do atendimento da estranha necessidade de não se ter as demais, a partir das básicas e daquelas da própria espécie na imediata condição do espécime. E isto constitui a esteira cujo movimento faz adentrar ao contraditório de se incidir em vítima ou em algoz da "sujeitação" própria ou alheia, respectivamente.

Nas histórias pessoal e social, torna-se oportuno questionar a falta de sentido de nascer e subsistir tendo necessidades, a começar pelas básicas e da espécie. $\mathrm{Na}$ ausência de tal sentido, atendê-las mediante produção também não faria sentido. Mas, se produção, própria ou alheia, tem de existir, ela há de assumir um significado que lhe é inalienável. Ademais, a automação total (ainda) resta utópica, porque, antes de tudo o mais, teria que ocorrer fora da propriedade de excludentes direitos sobre os pertinentes resultados e dos meios de estes serem obtidos. Assim, acesso a tal sentido terá que, ao contrário do que sempre se verificou, incidir em mais do que "nada", para se ir ao encontro do natural esgotamento da autoinsustentabilidade, em contraponto ao "internalizacionismo" que tem sido alheio às naturais e singulares potencialidades pessoais.

Por hipotético que ainda o tenha que persistir, impõe-se questionar a involuntariedade da inserção nas relações sociais, a começar por aquelas de produção. E tal questionamento há de inaugurar eticidade referenciada no sentido de produzir de modo inequívoco e opcionalmente empreendido. 


\section{3. "Alteridade institucional": proteção à fragilidade da autoafirmação propositivo- pedagógica}

A conjunção entre sentido humanizador das atuações pedagógicas e opcionalidade em as assumir há de significar alteridade àquela entre involuntária inserção nas relações sociais de produção e sociabilidade historicamente hegemônica. A propósito de ambas essas conjunções, tenha-se em vista o teor de uma assertiva em franca aceitação na IES em causa: "inequivocação quanto a produzir é o único assunto que há de ser considerado em todo tempo e lugar, porque, se a produção inequívoca não for opcionalmente empreendida, a sua imprescindibilidade se torna "ocasião que faz o ladrão" (constitui-se na oportunidade de a dominação ideologizar sua própria justificativa). Por que tal assunto tem pré-estado banido da prática educativa por inexplicável omissão das práticas políticas, tanto de educadores, quanto de prepostos institucionais?

Ainda que precise não ultrapassar mera hipótese, há uma lição contida nessa assertiva: determinada educação política tem como incidir em mudança qualitativa das relações inerentes à instituição em que ela própria se processa, ao passo que política educacional depende de inequivocação quanto a humanizar os prepostos e partícipes do processo político, dependência que responde à referida omissão, esta a se reproduzir na própria ambiência educativa e naquelas em que atuam os egressos vitimados por essa mesma omissão.

Em decorrência, cabe questionar a fundamentalidade do significado do que seja institucional em sua relação com o fenômeno político. Desse questionamento, infere-se que tal significado não tem como se desvencilhar de ranço ideológico, 
urgindo que seja esvaziado de quaisquer pretensões de inconteste justificativa.

Para início de arrazoamento dialético, não há como continuarem entre si desvinculados o que é naturalmente imprescindível e o que está culturalmente instituído como tal. Trata-se de desvinculação em que se encontra enredado o processo educativo, sem que os seus prepostos e partícipes se apercebam de que esse mesmo enredamento tem a ver com interessença em uma proposta pedagógica que se torne hegemônica, à medida que competência pedagógico-técnica passe a perfazer o emergente primado da competência tão só científico-tecnológica. Trata-se de competência em cujos domínios chegar-se-á à total anulação de conteúdo propriamente humano, anulação a ocorrer em duas e visceralmente cúmplices perspectivas: (a) por superfluidade, excrescência ou sobra, de tudo o que, alterinamente, houvesse de provir do interior para o exterior da pessoa; e, (b) por conteúdo tão somente adquirível ou a proceder de fora para dentro da pessoa que passa a se confundir com suas propriedades.

Por mediato que o precise ser abordado, a primeira dessas perspectivas tem sido resposta inerente à circunstância de a científico-tecnologia só emergir no bojo da propriedade, o que implica contestação do critério de o acesso aos resultados da produção guardar proporcionalidade direta com a extensão das propriedades. Para tanto, têm sido criados, em bases político-institucionais, direitos sobre tais resultados a serem transformados nessas propriedades, estando, à testa do processo, tributos e rendas privadas (líquidas de tributos), com suas inevitavelmente privilegiadas destinações.

Trata-se de contestação cuja processualidade desanda em guerra sem fronteiras, tirante à concepção heraclitiana do princípio filosófico-explicativo do mundo. "A" saída tende 
a incidir na determinação das injustificações em bases científico-tecnologicistas, bases que, a partir da história atual, venham a ultrapassar a logicidade natural-imperativa, tirante àquela registrada por Aristóteles a respeito da vocação dos bárbaros para serem escravos. Por sua vez, essa logicidade já ultrapassara, como se presume, a imemorial origem mítica das castas entre povos sul-asianos. Ademais, tal saída é de antemão incompatível com a prevalência dos valores da democracia e da cidadania. Assim, ou estes valores acabam preteridos, ou a pertinente "salvação" incidirá em "arrogância reivindicalista" e decorrente acirramento de conflitos, realimentando-se, não apenas os custos de sustentação do Estado, como também o preço da "sedução" dos empreendedores para gerarem meios que cubram estes mesmos custos. Em síntese, a absurdidade em construção tende a se tornar visível, até mesmo àqueles que não a admitem senão pela via fatal - por revolução às avessas de acabarem, real-concretamente, por ela atropelados.

Retornando às duas enunciadas perspectivas, a segunda, de acordo com a qual o conteúdo humano se reduz ao que é estritamente adquirível, tem a ver com alienação inercialmente autoconstruída. A pessoa é máscara ou estrita expressão de fenômenos reduzidos a um único, ela própria, a coincidir com uma acumulação de propriedades, cujos suportes advêm tão somente de fora para dentro. E este "dentro" é estrito resultado de fenômenos que têm de se transmutar em um suporte "aquencendente" (assimétrico a transcendente). A pessoa mesma não se admite enquanto originalidades inextinguíveis, mas existencialidade estritamente multideterminada e a se historizar em sincrônico-topocentria. Ela é não valoradora, ou mesmo antivaloradora, de limites natural-materiais. Estende-se por além da própria corporeidade e, para tanto, cerca espaços vitais que ela confunde com a sua própria existência e que passam a revesti-la. Ela, todavia, 
assume o "modo de existir "privacional"” (vazio, imaterial ou não sensorial, em que há de subsistir não mais do que desejo de si mesma e em cujo vácuo só cabem propriedades). Não fossem estas propriedades, a pessoa estaria totalmente esvaída, indeterminável e indefinível. Assim, à conta desta condição, as propriedades têm de subsistir atropeladas umas pelas outras, carentes de espaço para ocuparem e, ao mesmo tempo e lugar, extinguindo-o a todo custo ou preço.

É óbvio que ambas aquelas alternativas (de acabar anulado o conteúdo propriamente humano) devam ser rejeitadas, ao se considerar o significado de competência propriamente pedagógica. No bojo desse significado e apesar da inciência a seu respeito, persiste ao menos potencialidade de conteúdo inato, inalienável e imprescindível, ou seja, potencial de gratuidade. Em prol de tal rejeição, cabe discernir, em âmbito dominativo, o alcance animalesco da heterofagia apropriativa a acabar seletivamente aculturado como se produção o fosse e, no âmbito emancipatório, a radicalidade dialética do que restou deixado para trás, na irreconhecível esfera da mera generalidade, a (não menos animal) gratuidade de um excesso de intercâmbio orgânico com a natureza. E este excesso sempre se constituiu no que é mais radicalmente imprescindível à espécie (propriamente) humana, ou seja, à sua própria (re)produção ou à sustentabilidade também coletiva.

À base de tal discernimento, ainda a coincidir com um primeiro ato alterinamente cultural, é que a razão dialética viria a coincidir consigo mesma e a aperceber-se intelectualprodutiva. Tal ato assumiria procedência radicalmente diversa daquela do objeto filosófico da ideia hegeliana, a coincidir, conforme Habermas (1982, 28-43), com o (auto)-exame das condições de ela por si mesma se historiar. Por sua vez, este historiar-se já emerge no bojo da apropriação. Por isso, na 
imanência da propriedade, acabam por dissolver-se, um no outro, o modo de existir "privacional" da escassez criada e o modo de ser "ausencial" da "vontade". Sutilezas? Sim, não fosse também assim emergirem o alcance materialista da dialética em Marx e o caráter comunicativo da razão em Habermas, implicando que o proceder dialético, em ambas as circunstâncias, incida em alternativas e não em alteridade ou em inequivocação quanto a produzir intelectualmente.

Ao expor como o proceder dialético na comunicação racional em Habermas sucede ao materialista em Marx, Heck (1982) sumariza:

[... A pedra de toque da dialética materialista é o trabalho e não a conversão do homem. [...] cumpre dialetizar tal concepção de saber (dialética enquanto trabalho) com dados sócio-antropológicos como interação, comunicação, linguagem, poder. Para uma teoria do conhecimento, não pode ser indiferente, segundo Habermas, se o trabalho é encarado como um proceder instrumentalista ou se, como grandeza comunicativa, ele medeia também as leis que em Marx o regulam. Tal a priori dialético do materialismo, isto é, a incapacidade de negar seu princípio naturalista faz, de acordo com Habermas, que a teoria da sociedade se encontre apenas embrionária em Marx, que o fim da gestação desta teoria implique o corte do cordão umbilical que liga Marx às forças produtivas do século passado (XIX). (p. 15. Grifos no original. Nossos os termos entre parênteses). 
A respeito de dialetizar concepções de conhecimento, não há como prescindir de cada uma e de todas elas serem divididas. Na dialética materialista, trabalho não tem como emergir de antemão dividido, pois o próprio dividir-se já incidiria em trabalho, a não ser que se crie "lacuna metafísica" entre ideia de dividir trabalho e ideia da ação deste dividir. Assim, subsiste tão somente uma alternativa para a dialética materialista se libertar de metafísica, aquela de admitir, de uma vez por todas, que divisão do trabalho tem de significar autoafirmação e autonegação do próprio trabalho, prevenindo-se que ideologização de tal contraditório signifique também trabalho. A par disso, não se incide em nenhum deslize intelectual ao se reconhecer que tal ideologização tem coincidido com indiscernimento entre apropriar e produzir. Negar-se a trabalhar implica apropriar, uma vez que humano algum é anjo, ou seja, estar pura e simplesmente vivo significa já estar de antemão remunerado em termos de sustentabilidade. Esfalfar-se com impingir dominação nunca foi, é ou será inequívoco trabalho, ainda que na acepção de improdutivo. Entretanto, não é precisamente a tal impingir que Habermas se reporta, mesmo que admita dialetizar poder. Por isso, este aparece na citação acima como dado sócio-antropológico e em uma sequência tirante àquela de uma sucessão de notícias midiaticamente comunicadas.

Inferência cabível, ainda que hipotética, daquela exposição de Heck reside na preterição do alcance material do intercâmbio, às costas ou em ponto cego da concepção de trabalho em Marx e de sentido comunicativo da razão em Habermas.

Marx - custa não o admitir - subestimou, em seu método da economia política, a relevância histórica da categoria simples cujo real-concreto tem sido o intercâmbio de utilidades, ainda 
que o tenha abordado com especificidade diversa daquelas preferidas pelos economistas clássicos. O objeto propriamente científico da economia incide nas trocas de utilidades, em vez de nas circunstâncias em que as próprias trocas acabam incontidamente apropriadas (ranço politicista da economia, tão abundante nas análises de Marx). Na ausência de trocas, delimitações da produção se tornam impeditivas de propiciar amenização do padecimento do jugo da necessidade.

Quanto a Habermas, também custa não admitir que esteja a postergar o alcance material do intercâmbio, para não dizer o próprio intercâmbio enquanto matriz de fissuras, brechas e poros à emancipação no monólito da propriedade. Tal postergação ainda há de acabar atribuída à "situação epistêmica" da qual se projeta o olhar do observador. A propósito de tal situação, Freitag e Rouanet (1980), ao apontarem a perspectiva epistemológica na obra de Habermas, especificamente no livro intitulado "Conhecimento e Interesse", deixam transparecer que o real-concreto correspondente ao alcance material do intercâmbio sai de cena em favor de outro cujo concreto de pensamento incide em conhecimento instrumental (em oposição a comunicativo):

O conhecimento instrumental permite ao homem satisfazer as suas necessidades ajudando-o a libertar-se da natureza exterior (por meio da produção); o conhecimento comunicativo o impele a emancipar-se de todas as formas de repressão social (ou de seus representantes intrapsíquicos). Ambos estão, portanto, a serviço da emancipação. Esta é ao mesmo tempo um fim em si e um marco dentro do qual 
a teoria crítica consegue perceber as demais ciências, e a si própria, como interessadas (FREITAG e ROUANET, 1980. p.13. Grifo no original).

À luz dos teores dessa citação, cumpre indagar se o interesse emancipatório da própria teoria crítica emergiria isento de dominação, ou se, contrariamente, o próprio interesse não desandaria em "lacuna metafísica" (vazios espontaneamente subentendidos por entre categorias do pensar).

Em princípio, uma resposta seria alcançável, recorrendo-se ao proceder especificamente dialético, à base do qual, a teoria crítica (conhecimento) seja divisível entre os gêneros instrumental e comunicativo. Já estes gêneros também são divisíveis em espécies: o instrumental é definível como material e libertador do homem contra a natureza, enquanto o comunicativo é definível como imaterial e emancipador contra a repressão social. Chega-se, então, à inevitabilidade de se inferir vazios por entre as formas de imaterial e de emancipador, vale dizer, não se sabe como termina o imaterial e se inicia o emancipador ou vice-versa. Ignora-se, também, como a forma do comunicativo se superpõe às formas das suas espécies, sem que ocorra fim-começo ou começo-fim por entre forma superposta (dominativa) e formas subpostas (dominadas). Igualmente, a forma instrumental se superpõe a ambas as formas das suas duas espécies e por entre estas espécies há distância nada mais do que subentendida. Ademais, tem que existir fim-começo ou começo-fim por entre as formas genéricas de instrumental e de comunicativo. Tal inferência de vazios tem permanecido insignificante, nula ou um zero à esquerda. Entretanto, é nesta mesma insignificância que estão inevitavelmente a se apoiar os pés do observador. Assim, a sustentação do observador, na ausência 
de intercâmbio, teria que estar de antemão assegurada pela sociedade: a (ainda juvenil) autoinsustentabilidade do observador estaria a depender de ele ser proprietário da teoria crítica, assim como de criar escassez de tal propriedade. Todavia, "intercâmbio material-comunicativo" tem permitido a Habermas trocar suas publicações, assim como suas atividades de pesquisador e de professor, por utilidades que lhe têm possibilitado sustentar-se e contribuir para a sustentação coletiva, mediante pagamento de impostos e outras contribuições.

$\mathrm{Na}$ ausência das trocas, especificamente das sobras levadas a intercâmbio, a produção nunca ultrapassaria seu estágio (ainda e até mesmo) pré-bárbaro. Por isso, não resta de antemão descabido admitir aquela subestimação em Marx e essa postergação em Habermas. Ambas talvez procedam de eventual carência de análises comparadas entre mudanças sociais ao longo da emergência das cidades-Estado clássico-antigas e da urbanização moderna.

Em desfecho, uma eventual matriz de fissuras, brechas e poros emancipatórios, a perfazer o real-concreto do "intercâmbio material-comunicativo", continua deixada para trás, postergada ou preterida, de forma tão inciente a ponto de que "produzir educação" equivaleria a apelar para espantalhos, inclusive entre educadores meramente "noticiados" a respeito da dialética histórico-materialista.

Todavia, esses mesmos educadores não se cansam de reivindicar uso de tributos para sustentar suas atividades, de forma alheia à radical incompatibilidade entre tributação e humanização crítica. Paralelamente, eles não avançam em competência educativo-política para procedentemente argumentarem no sentido de a destinação de tributos ao processo 
educativo assumir reciprocidade de coerência com sustentabilidade também coletiva ou com parcial gratuidade de quem gera esses mesmos tributos, persistindo no imaturo e deseducativo discurso da gratuidade na perspectiva de quem apenas a recebe, nega ou apropria.

\section{Síntese dialeticamente arrazoada}

Livres empreendedores e prepostos do Estado precisam se dar conta de que, no pós-marxismo, eles deixam de ser, respectivamente, diretos e indiretos exploradores do trabalho humano, para serem vistos, junto à "arrogância reivindicalista", como detentores de riqueza ilimitada. Pouco ou nada importa tentarem explicar e, sobremaneira, justificar condição diversa. Por que, então e pragmaticamente, não acumular retornos de capital e arrecadar tributos, a todo custo ou preço? Prepostos do Mercado e do Estado estariam a se expor a surpresas dialeticamente arrazoadas? Qual o vínculo entre educação e a eventualidade de tais surpresas?

Ao que desde já é admissível ao menos conjeturar, nada impediria que mudança social provenha do ainda embrionário significado educacional da situação de "ínfero- referencial" (por entre o sentido de se ser parcialmente gratuito nas atividades docentes e o absurdo de se ter que sempre mais "pagar para produzir" serviços educativos). Antes de tudo, essa situação há de significar surpresa que emerge arrazoada, em bases dialéticas ou intelectual-inequivocamente produtivas.

Com efeito, alcance universitário da educação presume abertura, ao menos esta, à mediação que coincide com "incontinuidade-contato", esta enquanto parte por entre partes (ética e arte-estética) da totalidade (a própria educação) e, por força de tal mediação, o que significa universitário há 
de perfazer diferença própria e de forma onipresente às diferenças das demais partes (ética e arte-estética). Assim é que autoconhecimento, enquanto fulcro (razão) de um processo humanizador a se desdobrar também em ética e arte-estética, tem como ser deflagratório da busca de sentido propriamente universitário da educação. E, se esse fulcro não se autoafirmar por entre as diferenças das partes e a partir do "miolo" da totalidade (ética, razão e arte-estética), esse mesmo sentido não se coloca, nem mesmo em hipótese.

Deflagra-se o processo humanizador, a partir da percepção pelos mestres e pelos discípulos do caráter básico e inarredável da situação do "ínfero-referencial" (momento da "dialeticidiade da razão" que se depara situada por entre "absurdidade em construção" e geração de "gratuidade" coerentemente com "sustentabilidade também coletiva"). Este lugar-momento há de ser propriamente histórico e de coincidir com dialeticidade em si mesma. Nesta coincidência se "disformam" (opõem-se) razão e ciência. Em um (enfim) visível horizonte, ciência tem implicado desumanização a perfazer o binômio política-técnica (autoentrega à capacitação para construir absurdidade). Em outro (também enfim) visível horizonte, razão ainda há de facultar humanização em que ética e arte-estética detenham as próprias diferenças e, concomitantemente, estejam em mútuo contato. Em tal condição, ciência e técnica hão de interagir mediadas pela totalidade humana configurada por ética, razão e arte-estética, graças à opção pessoal por capacitar-se a mudar, no sentido de se ser coerente com "sustentabilidade também coletiva".

Tal coerência refletirá autoconhecimento e este coincidirá com porta de acesso a heteroconhecimento, à medida que valoração e rejeição de reais-concretos passem a afetar a relação ensino-aprendizagem e isto tenha como favorecer 
percepção e interpretação. Ademais, desalheamento quanto à mediação intelectual-produtiva há de perfazer condição de discernimento e de este facultar que os termos discernidos entrem real-concretamente em contato. Contrariamente, imotivação a conhecer tem respondido à estranheza dos reaisconcretos cuja mensurabilidade se torna excludente critério de perfazer o cosmo.

Há possibilidade de dinamização do acesso a heteroconhecimento, não apenas enquanto "afetividade" inerente à relação entre ensino e aprendizagem, como também enquanto congraçamento entre as próprias pessoas na ambiência universitária.

Quanto a prevenir estranheza, cumpre ter em vista que o natural esgotar-se da autoinsustentabilidade individual urge ser compensada por contrapartida cultural que, ademais, carece de coerência com sustentabilidade também coletiva. Mas essa compensação tem sido postergada, inclusive indefinidamente, à conta de omissão educacional. Já remover tal omissão há de incidir em razão mediativa por entre imaturidade e desequivocada adultez. Por seu turno, o significado mediativo da razão reside em prevenir "salto por sobre limites" da imaturidade e da própria adultez. A oportunidade de essa prevenção ser deflagrada coincide com a idade em que os jovens passam a se preocupar com autonomia, com profissionalização e/ou ingresso na universidade. Deflagrada, neste nível educacional, tal prevenção há de extravasar, à montante e à jusante, a atual graduação universitária.

A propósito desse nível, um sutil alerta é encontradiço nas entrelinhas do texto de Pistrak (2000, p. 169-223) sobre a auto-organização dos alunos e enquanto, também, fundamento da escola do trabalho. Essa auto-organização acabou - seria impossível negá-lo - por se "historizar" como 
estimuladora do interesse (em vez de evocadora da generosidade) na juventude comunista. Por sua vez, esse estímulo poderia ter aberto flancos a interpretações, até antitéticas ao que seja trabalho, a respeito da denominação de "trabalho improdutivo" que, segundo esse mesmo autor, "não é feliz" (p. 84). Trata-se de infelicidade que se confirmou com a futura derrocada do socialismo. Esta já era previsível aos próprios educadores soviéticos, logo após a Revolução de 1917, na postura política, formada ainda na juventude, que acabou silenciosamente cúmplice dos desmandos de Stalin, apesar dos milhões e milhões de egressos da "escola soviética do trabalho" cuja denominação talvez fosse mais verídica caso se denominasse "escola soviética da apropriação do poder". "Mutatis mutandis", o mesmo acontece na atualidade dos escritos de Mészáros (2005, p. 74-5), nos quais emergem imbricadas educação continuada e "prática significativa de autogestão", pressupondo que, a ambas, preceda universalização do ensino e do "trabalho como ativididade humana autorrealizadora" (p. 65). É que o significado desta última expressão emerge dialógico-alheado à inequivocação quanto a produzir, algo que o apelo à categoria "trabalho" efetivamente nunca supriu. Autogestão ainda carece de evocar mudança institucional no sentido de reduzir a própria negatividade, protegendo a condição radicalmente frágil de toda fonte de gratuidade. 


\section{Educação universitária em Barreiras e no extremo-oeste da Bahia}

\section{A. Missão}

Ao início, a missão da IES estava implícita naquela de índole organizacional da sua mantenedora, o Instituto Avançado de Ensino Superior de Barreiras - IAESB. Mas, assim que a prática educativa passou a ser mediada por pesquisa-ação a respeito de aspectos aplicados do paradigma da insustentabilidade coletiva, tornou-se possível explicitar uma primeira tentativa de formulação, a qual veio a ser apresentada mediante os seguintes teores: "certa educação universitária, cuja diferença qualitativa signifique, tanto economia de conhecimentos para educandos mais ameaçados de exclusão em sentido amplo, prevenindo-lhes inadvertida vitimação a macrotendências inerentes ao próprio processo cultural-civilizatório, quanto motivo de reflexão sobre o significado ético-competitivo da afirmação pessoal e corporativa, para os mais seguros de sua inclusão em largo alcance" (Grifo nosso).

Obviamente que o recurso à expressão "economia de conhecimentos" persistirá sendo funcional a interpretações na perspectiva de facilidades ou de ensinar menos conteúdos, a despeito do que precisa prevenir e da reflexão a ser motivada. Em decorrência, pesquisa-ação há de persistir voltada para suplementar, ou mesmo substituir, o termo "economia" daquela síntese formulativa, uma vez que a apropriação 
ideológica desse termo continuará impossibilitando que ele seja percebido e interpretado fora da mesquinha relação entre "arrogância reivindicalista" e liberalismo educacional. Essa arrogância, por sua vez, precisará ser prevenida no sentido de deixar de ocorrer sob particularizações ou equivocadas apropriações do significado de desalienação, desde aquele correspondente a "não se deixar explorar", até aquele já adotado pelo jovem Stalin e aceito pelo também jovem Lênin: pilhar o que for possível, para precipitar a inevitável revolução anticapitalista.

Com o avanço da pesquisa-ação o significado do termo economia aproxima-se daquele de inequivocação quanto a produzir, inclusas neste as atividades de acessar narrativas de saberes e interpretá-las na realidade imediata do educando, no sentido de esta interpretação facultar operagem e consolidar conhecimento, além de incidir em coerência com sustentabilidade também coletiva ou com o caráter alterinamente institucional da gratuidade. Esta, por sua vez, cumpre perfazer princípio que faculte ir ao encontro da "individuação íntegra" do educando.

Assim, inequívoca produção há de corresponder ao pensar que se descobre determinado, também e definitivamente, pela espontânea emergência das necessidades natural-básicas, a serem atendidas em reciprocidade de coerência com intercâmbio orgânico com a natureza, intercâmbio que deixa de ser direto e carece de condizente instalação no mundo das trocas. Trata-se de emergência a acontecer do interior para a aparência da pessoa e que, nesta, determina atividade cerebral por via antagônica àquela dos cinco sentidos. Por sua vez, o alcance antagônico dessa via, com seu próprio e emergencial sentido, não tem influenciado as concepções de método, inclusive a própria dialética. É que, nas vertentes do 
experimentalismo e do positivismo, apenas o estofo funcional das especificidades tem sido bastante para fundamentar objetos que atendam às regras cientificizantes do método. Mas, a via assim antagônica, ao ser também influenciável, há de preceder aquele estofo e de co-determinar método para inferir caráter íntegro da individualidade humana. Em suma, a mediação do discernimento entre apropriar e produzir há de significar religação entre os teleconvergentes sentidos do mover-se das necessidades vital-básicas e do mover-se das funções de as atender.

Compõe a missão da IES perceber, interpretar, conceituar e "crítico-teorizar" o caráter íntegro da individualidade humana, assumindo posicionamento em prol da promoção deste caráter junto aos educandos, peculiarmente junto àqueles que se encontram no limiar de assumir a própria adultez.

Entrementes, cabe-lhe constatar dissonância entre um tal posicionamento e aquele de tão só as funções das especificidades constituírem fundamentos dos objetos de conhecimento. Para tanto, cumpre desenvolver a pessoa humana em sua singularidade, evocando-lhe a "dialeticidade da razão". Neste horizonte de autoatribuições, a própria razão-de-ser da pessoa há de se dialetizar por entre opcional geração de gratuidade e cultural-civilizatória construção da absurdidade, mediante difusão de argumentos a respeito de que a premência por avanços científico-tecnológicos, de índole antes de tudo devastatória do Planeta e das potencialidades de seus habitantes, tem tido, por contrapartida, um recorrente impasse junto às humanidades em perceber, interpretar, conceituar e "crítico-teorizar" a negação da gratuidade, a começar pela humana. Urge-lhe, então, posicionar-se em prol, não só da ultrapassagem de tal impasse, como também de mudança na concepção de tecno-ciência, facultando que esta se emancipe 
do reducionismo inerente à incontida artificialização do meio ambiente e passe a também promover a diversidade vital-fértil da natureza, a começar pela humana.

Em síntese, a missão da IES propende a promover educação que se torne mediadora entre desconstrução da absurdidade e soerguimento do que, em sua própria concepção dialética, veio a ser denominado de inequivocação quanto a produzir serviços educacionais. Será a prestação destes serviços, graças a determinado perfil de seus egressos, a via de influir junto aos determinantes do futuro de Barreiras e do Oeste da Bahia. Para tanto, cumpre priorizar funções que precisam ser exercidas à base da especificidade do processo educativo, resistindo, no âmbito dos limites regulatórios, ao assédio de prepostos do poder que teimam em transformar as IES em agências-propriedades da construção do absurdo, inclusive ao onerá-las com obrigações físicas fora da ambiência propriamente educativa.

\section{B. Objetivos}

Desde a pertinente projeção, os objetivos da IES hão de emergir no contexto da práxis coletiva que, para tanto, cumpre se desdobrar em ousadia desconstrutiva da absurdidade e em humildade de produzir de modo inequívoco e opcionalmente empreendido. Ambas - ousadia e humildade - constituem necessidades e, uma vez emergentes, hão de evocar funções de as atender.

A práxis coletiva, por si mesma, cumpre assumir conotação de absoluto material e precisa ser vivenciada como pedra de toque da especificidade dialética que perfaz, por aquém 
da ambígua idealidade de trabalho, a instrumentalização do processo a ser seguido.

Todavia, a conotação de absoluto material da práxis coletiva há de permanecer mera hipótese e ter como operar relativizada, dada a contingência da opcionalidade, a par de que há de guardar reciprocidade de coerência com as demais hipóteses - estas levantadas, ao longo da investigação, e aprofundadas em seus teores até ao ponto de contagiar os fundamentos aos quais se reportam. Em suma, é dessa reciprocidade de coerência que há de provir apoio para decisões político-institucionais cuja premência não tem como ficar à deriva de que, um dia, a ciência propriamente pedagógica se liberte de suas colonizações.

Reciprocidade de coerência também precisa vir sopesada entre os próprios objetivos, inclusive já ao serem projetados. E esta projeção há de escudar-se em horizontes dialético-procedimentais que favoreçam "historicidade" do minguamento da falta de interação até lograr "incontinuidade-contato" por entre diferenças de ambiências educativas, correspondentes à IES e às demais. Neste sentido, cumpre de antemão entender que a proposta educacional não é exclusiva da Instituição, peculiarmente, pela ênfase em se voltar para o princípio constitucional (Art., 205) de a educação promover o desenvolvimento da pessoa, princípio que continuou impreciso na formalidade da LDB (Art. $2^{\circ}$ ).

Nessa perspectiva, entra em cena a função da responsabilidade social da IES, sob a delimitação da sua missão especificamente educacional. Trata-se de objetivar como a educação universitária há de emancipar-se da sua social e estritamente exógena multideterminação, passando a influir, em sentido acentuadamente dinâmico, no futuro da socioambiência local e regional. É-lhe solicitado reavivar a 
epopeia anti-isolacionista dos fundadores de Barreiras, graças a "intercâmbio material-comunicativo" por entre os espaços mais centrais do Centro-Oeste e do Nordeste do Brasil.

Cumpre priorizar qualidade e cientificidade do perfil dos egressos, à medida que a mediação dialética do discernimento entre apropriar e produzir vier a perfazer, por hipotético que ainda o seja, não apenas objeto da pedagogia e esta deixe de se resignar à condição de vazio a ser colonizado, como também a especificidade da própria área de conhecimento e esta especificidade deixe de estar marginalizada, informalizada e sócio-subjetivada na totalidade da ambiência acadêmica.

Paralelamente, urge ser confirmado, junto ao caráter opcionalmente empreendido da práxis coletiva, que tal discernimento há de perfazer o "fundo do poço" em termos de fragmentação das humanidades.

Então, o acesso da docência à inequivocação quanto a produzir há de incidir em inusitado caráter "interdisciplinar" do ensino e de facultar avaliação da aprendizagem por produção.

Aos prepostos da IES, assim como aos educadores que nela atuam, cumpre que se apercebam do significado propriamente universitário da qualidade e da cientificidade da educação a ser promovida e que tal significado há de favorecer o desenvolvimento da atual Faculdade para Centro Universitário e finalmente Universidade.

\section{Resultados alcançados}

Por sua exposição ao vezo das incontinências apropriativas, resultados costumam ser muito restritos e contar com 
excludente paternidade que os acredite mais relevantes do que propriamente o sejam. Entretanto, os resultados da pesquisaação acima relatada emergem disfuncionais a esse vezo. Isto se deve, antes de tudo, à sua paternidade, que é um coletivo, e à circunstância de os resultados procederem de empenho inarredavelmente opcional. A par disto, o caráter assim coletivo e opcional thes constitui inalienável critério de qualidade. Quanto a serem ou não serem restritos, há um paradoxo a ser considerado e que os situa por entre aparente inexpressividade e um ainda incomensurável alcance, ao se ter em conta determinado ponto cego do pensar pós-metafísico, ou seja, ponto que perfaz princípio pelo qual o indivíduo há de se explicar e de se aperceber justificado na sua relação com coletivos sempre mais complexos e a partir do natural-mínimo.

Com efeito, há o princípio segundo o qual produzir de modo inequívoco seria o único fenômeno que caberia ao ser humano ser obrigado a assumi-lo. Todavia, quis a natureza, ou mesmo a própria deidade, que tal obrigação jamais se justifique, pois a atividade de assim obrigar, por mais resultados que possibilite, nunca incidiu diretamente em produção, mas na antítese desta. Por sua vez, tais resultados sempre corresponderam a condições culturalmente criadas, além de admitidas na perspectiva de sujeitar outrem a produzir de modo inequívoco e forçosamente gratuito. Assim, esta sujeitação tem coincidido com o fulcro cultural-civilizatório que perfaz a própria história. Então, em humanidades, caráter inarredavelmente opcional quanto a empreender inequívoca produção é garantia de qualidade enquanto critério de fundamentar caráter também humano de ciências. É que, de per si, cientificidade nada mais traduz do que mera fundamentação de a ciência ser possível, o que, fenomenicamente, tende a estar oculto sob o que tem estado manifesto enquanto ciências humanas. 
Então, em perspectiva desocultadora, expressões entre aspas compuseram o contexto das conceituações formuladas ao longo da investigação, assim como emergem recuperáveis no glossário que consta das páginas iniciais deste texto. No caso de corresponderem a propostas de mudança qualitativa e científica do processo educativo, as conceituações são tidas por ainda hipotéticas e precisam, em relação à individualidade humana, guardar reciprocidade de pertinência ao serem corroboradas e de coerência com justificação. Por sua vez, a individualidade humana há de assumir alteridade de relacionamento social na contingência das alternativas deste mesmo relacionamento, alternativas que se caracterizam pela marxiana involuntariedade da inserção nas relações de produção, a começar pela produção de serviços educacionais.

Ao final do processo investigativo, chegou-se ao que veio a ser hipotetizado como "ínfero-referencial", cujo objeto é projetado como básico e inarredável por desvelar "razão material-comunicativa" no educador e, a partir deste, o potencial de essa "razão" se difundir na ambiência educativa cuja particularização ou especialização precisa ser explicada e, enfim, justificada no contexto social. A expressão "ínfero-referencial" se torna na síntese das demais, precisando ser antecipadamente comunicada, porque este procedimento facilita comunicar e perceber o significado de todas as demais.

Para chegar ao cabal significado de "ínfero-referencial", o que só ocorreu já ao desfecho da pesquisa-ação, contou-se com um outro, intermediário, aquele de "crítico-teoria". Por seu turno, este resultado intermediário seguiu a três outros, em uma sequência gnoseogenética que responde à emergência das necessidades a partir do interior da pessoa. 
Destes três outros resultados, o primeiro havia emergido já anteriormente e sua observação restava ainda muito tosca. Mas, por incidir em objeto de contínua revisitação ao longo das atividades de pesquisa, veio a ser conceituado como "paradigma da insustentabilidade coletiva". Assim, o aprofundamento dos teores deste paradigma respondeu à circunstância de que uma primeira percepção e correspondente interpretação vieram a mediar educação universitária, a partir do ensino da economia política, bem como da possibilidade de essa mediação atingir campos de atuação humana ou de cursos profissionalizantes e, no âmbito destes cursos, mediar teores de disciplinas. Em decorrência, o que compunha ainda toscamente a interpretação inicial logrou contínua "crítico-teorização" do seu entendimento, seja em alcance de ciência positiva, seja por confronto com a "dialeticidade da razão". Esta, por sua vez, passou a mediar a obtenção de conceituações subsequentes, dentre as quais aquela de "discernimento entre apropriar e produzir" e, no bojo deste discernimento, "gratuidade", ou melhor, resultados e/ou atividades parcialmente fora da propriedade da pertinente fonte.

Por modesta que ocorresse ao seu início e por sua perspectiva de influenciar mudanças na interioridade do processo pedagógico, a práxis (coletiva e assim mediada) da educação universitária veio a favorecer que, sucessivamente, fossem inferidos outros significados: "sustentabilidade também coletiva" - precocemente guindada a paradigma - com os seus pedagógicos componentes de "posse e despossessão do coletivo natural-mínimo”, ambas - posse e despossessão - inerentes à "relação entre prole e quem, direta ou indiretamente, a sustenta". O significado de "despossessão do coletivo naturalmínimo”, ao ser vislumbrado como mediador de atividades em que convergiam disciplinas do Curso de Comunicação 
Social, possibilitou que se consolidasse um situado entendimento a respeito de "trabalho interdisciplinar", cujos resultados práticos se aproximavam de efetiva produção de grupos de alunos, facultando que, mais adiante, fosse projetada a meta institucional de ser feita "avaliação também por produção" e, por inferência, passou a ser possível aprofundar o teor correspondente a tal avaliação.

Entrementes, exercícios de reflexão das práticas docentes, conduzidos por uma experiente pedagoga e educadora à frente do que se convencionou denominar Programa de Apoio aos Docentes (PAD), responderam por certos avanços nos teores da proposta pedagógica. São avanços que apontam para o horizonte da "individuação íntegra" da pessoa, à qual há como chegar mediante determinada revisitação da "maiêutica" socrática. Para tanto, a filosofia procedimental de Sócrates acabou atualizada como desequivocação dolorosamente parida das faculdades humanas da "vontade" (autoimpulsão para assumir "gratuidade"), da "afetividade" (sociabilidade isenta de desejos interesseiros) e da "razão" (inteligência por entre "vontade" e "afetividade", assim desequivocadas).

A busca de mediação de teorias pedagógicas externas à IES veio a reforçar o teor procedimental-dialético da pesquisa-ação, à base de três temáticas de pesquisa (já referenciadas na Introdução), as quais são investigadas na Faculdade de Educação da Universidade Estadual de Campinas (FE/ UNICAMP): (a) a dinâmica do desejo como "assunto socrático" da filosofia clássico-antiga, dinâmica cujos labirintos disputacionais influenciaram a concepção da (então) nova paideia; (b) a acentuada recorrência à dialética na efetivação de pesquisas educacionais, paralelamente ao avanço da concepção dialética do processo educativo; e, (c) a antisseletividade 
(tácita às conotações de democrática, ou mesmo de política, da educação) que também diz respeito ao entendimento do sentido histórico-crítico da pedagogia.

Dessa busca resultaram os entendimentos sobre o suporte existencial da "forma por entre opostos". Trata-se de suporte tão real-concretamente fundamentado quanto os "modos de existir privacional e presencial", respectivamente, "privacional" enquanto característica dos objetos de desejo ainda não realizado ou irrealizável e "presencial" enquanto característica sensível de propriedades extrínsecas à pessoa.

De modo contraposto, assim como oculto nas dobras do fenômeno da individualidade e assimétrico à "situação epistêmica" do observador, interpreta-se, nos contrafortes do "paradigma da sustentabilidade também coletiva" e à base dos teores da "relação entre prole e quem, direta e indiretamente, a sustenta", o fulcro essencial da " forma' por entre sentidos" do "modo de ser 'ausencial", respectivamente, sentido da exsurgência das necessidades naturais e da convergência das funções de as atender.

A garantia de cientificidade aos entendimentos a respeito do "paradigma da sustentabilidade também coletiva", da "gratuidade" e do "discernimento entre apropriar e produzir" resulta ao menos defensável, à base dos teores da "relação entre prole e quem, direta ou indiretamente, a sustenta". Esses teores constituem referência, a partir da qual se torna possível inferi-los. De fato, resta descabido duvidar da procedência desses entendimentos, salvo direito a dúvidas, ou mesmo, apelo ao livre arbítrio, os quais previnem chegar até eles. Paralelamente, perfazem teores que têm sido reduzidos a nulidades, dada a circunstância de estarem marginalizados, informalizados e sócio-subjetivados no bojo da indiferenciação entre apropriar e produzir. 
Em contraponto, cabe ao caráter emancipado - opcional e parcialmente gratuito - do sentido coletivo da práxis pedagógica, assim como à efetividade desta mesma práxis, constituírem garantia da qualidade e, por decorrência desta, da precisão da cientificidade daqueles entendimentos. Assim, nesta práxis, há de acabar interpretável o que permanece oculto, nas dobras do que está manifesto, a respeito do fenômeno da individualidade. Cumpre, então, auscultar tal interpretação, à base das falas dos docentes, constante dos textos-testemunhos que foram produzidos no contexto dos encontros realizados pelo Programa de Assessoramento aos Docentes (PAD).

Com efeito, as expressões acima referenciadas aparecem nesses testemunhos. Dentre elas, as mais recorrentes são as que reportam ao "discernimento entre apropriar e produzir" (68 vezes); "paradigma da sustentabilidade também coletiva" (67); "gratuidade" (42); "avaliação também por produção" (28); "trabalho interdisciplinar" (21); "paradigma da insustentabilidade coletiva" (18); e, antisseletividade (13). Apesar de serem as menos recorrentes, estas duas últimas expressões acabam sendo as mais significativas, pois a antisseletividade constitui a principal interface da proposta pedagógica com o caráter histórico-crítico da pedagogia, enquanto o entendimento do que seja "insustentabilidade coletiva" coincide com o multifacetado determinante da própria seletividade, ou seja, com a circunstância de se ter que pagar acentuadamente mais para apenas produzir, dado o inchaço da proporção correspondente a tributos e demais rendas (isentas de tributos) de estrita propriedade na formação do preço final dos meios de trabalho. Por outra parte, tirante à dificuldade de interpretar textos marxianos de economia política, há veladas reclamações (31 vezes) a respeito de ser inicialmente 
muito complicado acessar os fundamentos da proposta pedagógica. A este respeito, merece ter em vista que elucidar os fundamentos da economia política, inicialmente junto ao alunado e posteriormente junto à docência, veio a se constituir na razão de a proposta pedagógica ser deflagrada.

A proporção dos testemunhos, em que ocorrem as expressões em causa, também é um indicador do avanço da práxis pedagógica coletivamente assumida. Assim, a porcentagem dos testemunhos em que constam dizeres pertinentes à expressão "paradigma da insustentabilidade coletiva" (inclusa a dificuldade inicial de entender a proposta) é de 67\% (31 dos 51 testemunhantes); "discernimento entre apropriar e produzir" também é de 67\%; "gratuidade" é de 49\%; "avaliação também por produção" é de 33\%; "trabalho interdisciplinar" é de 24\%; "paradigma da insustentabilidade coletiva" (exclusa a dificuldade inicial) é de 29\%; e, antisseletividade é de $16 \%$. A dificuldade inicial de acessar os fundamentos ocorre em $45 \%$ dos testemunhos. Os docentes do curso de Pedagogia, os quais compõem 18\% dos testemunhos, foram responsáveis por 31\% das expressões explicitadas (cerca de dez por testemunho), inversamente ao que ocorreu com os demais, $82 \%$ dos testemunhos e 69\% das expressões (cerca de cinco por testemunho).

Cabe admitir, afinal, que há indicação de que a proposta pedagógica esteja a vingar na IES, ao se ter em conta que $45 \%$ dos docentes se prontificaram a contribuir com a elaboração de testemunhos, a par de que tal contribuição foi mais significativa no curso de Pedagogia do que na média dos demais.

Entretanto, seria até injusto aquilatar as contribuições dos docentes estritamente à base do apelo a algo que tenha como acabar tachado por "chavões". Estes, ademais, costumam denotar condutas de apropriadores recorrentemente 
alheios a respeito de que, para tanto, se encontram necessariamente apoiados em "situação epistêmica", vale dizer, na posse extemporânea do coletivo natural-mínimo ou na usurpação das oportunidades de a suficiência do coletivo implicar explicação e justificação do indivíduo. Assim, urge citar contribuições na perspectiva de suplementar as falas dos docentes.

Nesta perspectiva, faz diferença que não haja explicitação de restrições à proposta. Contrariamente, cabe projetar aceitabilidade em franca difusão.

As contribuições ultrapassam apelo a expressões-chave. Por isso, é delas mesmas que emanam critérios para aquilatálas, sob três posicionamentos medianamente mais assumidos: autoabandono a dificuldades iniciais; rendição ao imperativo da prática ou à defasagem teórica; e, franca abertura a avanço também teórico.

Autoabandono a dificuldades iniciais dá-se a conhecer, ao ser apontada complexidade - complicação a rigor - a respeito das condições de acesso aos fundamentos da proposta. Neste aspecto, resta implícito que muitas falas emergem vitimadas a implicações do "paradigma da insustentabilidade coletiva", cuja complicação tem respondido, ao menos em parte, pela resistência em admitir que utilidade, economia, ou mesmo produção frequentem ambiências tidas por educacionais. Trata-se de complicação entre cujos determinantes sequer é cogitado que se encontre omissão educacional quanto a dinamizar inata generosidade do educando, mas, ao contrário, que neste esteja a ocorrer internalização de interesse culturalmente criado. Entretanto, interesse não combina com esforço que, por sua vez, é necessário à dinâmica do processo ensinoaprendizagem, seja da parte do educando, seja do educador. De todo modo, não há apelo a desculpas que veladamente 
rejeitem a proposta educacional, inclusive porque resta a alternativa do anonimato (55\% dos professores não formularam textos-testemunhos).

Rendição ao imperativo da prática ou à defasagem teórica aparece em falas, nas quais emerge anuência à proposta porque desta advêm faíscas teóricas que atingem o mundo da prática. A anuência traduz certo substrato histórico da aprendizagem, aquele de que o produzir inequívoco acabou retardado até o limite do possível, graças a oportunidades de tão só apropriar. Disto resultou ideologizada a imediata prontidão dos meios de vida como prevalente determinante da qualidade, ou seja, do que é aquilatado como melhor. Rendição à ideologia desanda na escassez do que é melhor e, com esta escassez, tornou-se também melhor o saber de aprontar aqueles meios. Na verdade, tornou-se melhor para outrem que contasse com poder para transferir o ato de aprontar e até o próprio saber. Assim, resta tácito que a aceitação da proposta sinalize para insuficiência de teorias vigentes e anteriormente acessadas, sem excluir precariedade em tal acesso. Com isso, favoreceu-se percepção e interpretação da relevância da "gratuidade" da perspectiva de quem a gera, com eventual explicitação ou pressuposição do que possibilita fundamentá-la ("discernimento entre apropriar e produzir") e ao que conduz seu significado ("sustentabilidade também coletiva"). Entusiasmo pela proposta é frequentemente declarado, mas não há como negar que se encontre tacitamente a se generalizar. Não raro, ensaiam-se ajuizamentos de largo alcance sobre o significado da proposta em sua totalidade.

Franca abertura a avanço também teórico emerge como promessa de a proposta vir a vingar, apesar das implicações do "paradigma da insustentabilidade coletiva". No caso, as próprias contribuições perfazem "avaliação também por 
produção", desvelando ou presumindo "interdisciplinaridade" para explicitá-las.

A seguir, são apresentados excertos de textos, os quais traduzem tal promessa e que foram dispostos, segundo três orientações: (a) de direta ou indireta autorrealização da docência; (b) de desempenho do processo ensino-aprendizagem; e, (c) de (ainda escassos) desdobramentos no meio sociogeográfico:

a) de direta ou indireta autorrealização da docência

"A proposta pedagógica da FASB oferece um conjunto de fundamentos capazes de ressignificar nosso modo de interpretar a realidade que nos cerca. (...) acredito piamente na 'reciprocidade de coerência' evocada pelas categorias de análise no movimento da práxis educacional".

“(...) a organização do trabalho pedagógico da Faculdade está alicerçada em termos teóricos, de procedimentos e de hipóteses de trabalho na questão sustentatória, constituída na dinâmica entre apropriar e produzir, traduzida no atingimento da meta de "Avaliar Também por Produção". Isso implica em lançarmos um olhar investigativo-reflexivo sobre a práxis educativa e necessariamente estabelecermos uma relação dialética entre o processo ensino-aprendizagem e a avaliação. (...) a Proposta constitui uma troca dialógica daquilo que se produz em sala de aula e das dificuldades que o Ensino Superior enfrenta na busca da alteridade educacional, estabelecendo uma relação dialética com os pressupostos do Paradigma da Sustentabilidade Coletiva. Preenche, pois, os vazios existentes no espaço acadêmico, o que somente é possível com o produzir inequívoco e espontaneamente empreendido. Assim, possibilita não apenas a construção dos processos de relações 
sociais acadêmicas ancoradas na sustentabilidade e comprometidas com o coletivo, como também a modificação dos eixos centrais da gestão, que promove a geração de ideias numa produção social e numa rede de relações campartilhadas. (...) Acredito que, diante da insustentabilidade global, todo gestor comprometido com a sustentabilidade, precisa enxergar o ser humano com necessidades a serem atendidas e as funções de as atender e reconhecer que a gratuidade foi historicamente anulada, negada, extirpada. Daí a importância em encontrar fissuras, brechas, ou frestas, criando espaços vitais que evoquem a potencial fonte humana de gratuidade em termos coletivos". (...) O trabalho empreendido aqui na FASB é um desafio, uma utopia possível e principalmente um convite a todos os envolvidos a pensarem e a realizarem o quefazer pedagógico de modo a evocar, em cada educando, a potencial fonte humana de gratuidade, ou seja, a produção inequívoca e opcionalmente empreendida".

"No ano de 2006, com a sistematização dos estudos e discussões pelo Programa de Assessoria ao Docente" a instituição pôde consolidar o processo de construção de sua proposta pedagógica”.

“(...) a Instituição FASB tem uma missão - promover uma educação de qualidade, oferecendo uma 'economia antisseletiva' de conhecimento para os menos favorecidos deste patrimônio histórico-cultural e uma grande reflexão para os mais favorecidos, ou seja, ensinar significativamente aqueles que necessitam de melhorar seus conhecimentos e oferecer caminhos que levam à reflexão para aqueles, que porventura detêm certo grau de conhecimento, contudo não sabem utilizá-lo para o bem coletivo”.

“(...) educar é ensinar a alguém a não ser parasita dos outros e/ou da natureza. (...), pois se apenas (nos) apropriamos 
de verdades estabelecidas estaremos realizando um verdadeiro atentado contra a inteligência humana. (...) necessitamos traduzir o conhecimento em estilo de vida, em comportamento efetivo, numa reinvenção do sentido do mundo".

"Existe toda uma desconstrução a ser feita em todas as esferas - pessoais e institucionais - para que estes novos paradigmas se concretizem".

"No meu entender a FASB se diferencia da maioria das instituições educacionais por fomentar a discussão acerca da educação que desenvolve. (...) Uma nova ciência e uma nova conduta devem possibilitar a criação de condições da sustentabilidade coletiva. Compreender e discernir os condicionamentos históricos do apropriar e do produzir foi o ponto mais significativo que inicialmente compreendi e que serviu de referência a meu trabalho pedagógico”.

"A primeira visão da gratuidade de um profissional que foi moldado, em sua formação, de que seu trabalho só tem valor quando consegue fazer com que seu patrão obtenha lucros, já é de se esperar que não foi muito fácil, e essa visão aos poucos foi clareando, à medida que somos inseridos nesse processo, e isso aconteceu aqui na FASB. Atualmente, podemos ver resultados de que uma sociedade justa e sustentável não é utopia, e pode facilmente ser implantada, desde que acreditemos nela. (...) Estou grato por poder enxergar algo mais em minha vida, e com certeza, grato de poder devolver parte de minhas experiências com meus alunos, e ainda, poder viver melhor, com minha consciência tranquila e feliz, e assim, é claro produzir mais e cada vez com mais qualidade".

"Aqui, com essa proposta, deixei de me sentir um tolo, e hoje me considero mais professor do que nunca". 
“(...) a proposta FASB é hoje uma construção a ser trabalhada diariamente, traduz (e com certeza) que os convencimentos em torno das ideias e sua aplicação devam acontecer na vida pessoal primeiramente à sua utilização/aplicação em sala de aula”.

"Fiquei muito surpresa ao perceber que a ideia do Paradigma da Sustentabilidade Coletiva andava lado a lado com algumas concepções que eu havia desenvolvido ao longo do curso de Mestrado, no qual vivenciei um grande processo de desconstrução de uma visão cartesiana da realidade".

"Entendo os pressupostos teóricos do Paradigma da Sustentabilidade Coletiva como o início de um processo promissor na educação".

"Hoje, a proposta fasbiana de educação vem tomando formato próprio, já que o paradigma da sustentabilidade coletiva vem gradativamente quebrando paradoxos, substituindo velhos hábitos inseridos nas mentes de educadores e educandos de um grupo numericamente e qualitativamente significativo".

"A proposta de educação fasbiana tem me ajudado a reconhecer e confirmar que é necessário romper os velhos paradigmas e tem ajudado a aproveitar o que o aluno pode produzir cientificamente no processo de avaliação acadêmica. (...) em princípio ficou claro que não há como se fazer educação sem levar em conta a sustentabilidade coletiva. Este, num futuro próximo, deverá ser um princípio a ser observado em todas as ações dos indivíduos".

"Em meio a uma enorme diversidade de pensamentos individuais (pessoas), nas mais diversas áreas do conhecimento, cada professor navega conforme seus valores e capacidades, elementos que de certa forma constituem-nos individualmente, 
mas que através da Proposta Fasbiana criam uma construção coletiva do conhecimento".

"Os pressupostos (...) permitiram-me a redução dos conflitos com o corpo discente, em especial por estarem promovendo uma educação menos apropriativa - simples reprodução dos conceitos, antes considerados como únicoverdadeiros -, conflitos ainda mais agravados quando não avaliados também por produção, ou seja, que se oportunize ao discente demonstrar sua evolução (crescimento) como pessoa estudante e profissional. (...) Comparando alguns textos destes pensadores (Smith, Malthus, Ricardo e Mill) com a teoria da insustentabilidade coletiva, observei que os problemas que a desencadeiam estão relacionados não só com o modo de produção, mas também com a ausência (ou o ocultamento) do discernimento do produtor inequívoco 'versus' apropriador".

"O exercício da reflexão permitida pela Proposta Pedagógica mostra conquistas seguras, dinâmicas e abertas a novas possibilidades, daí o alcance das perspectivas. (...) Em discussões realizadas, no colegiado, a troca de relatos nos permitiu evidenciar que as angústias não estavam resumidas apenas a um só, coletivo no grupo experimentavam tais situações. A diferença se fez na aceitação da proposta, que a princípio teve de ser internalizada pelo próprio professor para então ser colocada em prática com o nosso alunado".

b) de desempenho do processo ensino-aprendizagem;

"Os dois primeiros semestres foram difíceis pelo conflito entre professor e alunos. O que me acalentava é que esse problema não se restringia somente à minha pessoa". (...) A partir da aplicação dessa Proposta, os conflitos foram esvaecendo e as descargas de adrenalina, momentos antes de entrar numa 
sala de aula e durante a explanação oral de determinado conteúdo, foram, também, despercebidamente esquecidas".

"Percebo que não devo ser um repetidor de conteúdos inúteis para mim e para os outros, meus alunos".

"Tratamento e relação aluno-docente passam a ser mais individualizados no sentido do acompanhamento. A metodologia em sala de aula que passa a ser constituída a partir da necessidade de que o aluno gere conhecimento não somente do que está escrito nos livros, mas da observação sistemática; o pensar na perspectiva da mudança, o sentir na dialética da percepção ambiental, etc. A contribuição para autorreflexão e pró-ação dos alunos a partir de trajetórias individuais (autobiografia). A produção, e de sinais desta, quando o aluno deixa de ser o acaso da história e passa a ser o responsável por si mesmo - "autônomos" (agir segundo as leis e com base em princípios que guiem as suas condutas)".

“(...) enfrentava no curso de Fisioterapia muitas dificuldades com relação à aprendizagem e a falta de interesse de alguns alunos. (...) Hoje verifico que a inserção do projeto interdisciplinar faz com que o aluno se integre mais no mundo acadêmico, com uma versão crítica do seu futuro como profissional. Os professores se sentem mais seguros e incorporam essa atividade como parte de sua disciplina, fazendo com que este projeto seja espelho do desempenho dos alunos e professores no curso".

"Percebi que os alunos passaram a refletir mais sobre a realidade que os cerca e principalmente, que nós precisamos produzir para o outro, ou seja, para o coletivo, a fim de evitar o colapso das relações humanas de sobrevivência”.

"A forma de moldar os conceitos da nossa proposta para a sala de aula foi e é o grande desafio ainda presente, porém 
existe uma grande revolução neste sentido, pois a simples internalização das bases teóricas da proposta proporciona uma mudança de atitude espontânea do educador inserido nesta reflexão".

c) de desdobramentos no meio sociogeográfico:

"A materialidade da produção extrapolou os limites da sala de aula e felizmente temos exemplos de pessoas tomando as rédeas de suas histórias".

"A proposta me fez perceber com mais clareza a necessidade do ensino se tornar significativo ao estudante, do ponto de vista profissional e humano".

"A proposta fasbiana favoreceu um melhor planejamento metodológico na medida em que possibilitou instigar o aluno a encontrar o ponto certo ou o encaixe perfeito da disciplina estudada no pragmatismo do dia-a-dia”.

As falas acima apontadas servem para corroborar, por efêmero que o pareça, as hipóteses ainda toscamente formuladas no projeto de pesquisa-ação. Cumpria expô-las à aquilatação, inclusive em alcance também teórico-crítico e fora da IES de origem. Até certo ponto, elas haviam emergido à revelia do metropolismo, além de influenciadas por sociabilidade mais espontaneamente constituída. A rigor, precisam refletir civilidade que surgiu em profundezas isoladas e pouco ou nada controláveis do domínio privado que foi característico da sesmaria nos mais retirados sertões nordestinos.

A primeira dessas hipóteses foi estipulada de forma sintético-referencial e nos seguintes termos. 
Conduta coerente com sustentação também coletiva, por mais que ainda tenha que se restringir a mero "rito de passagem" e que precise acontecer somente após acesso ao discernimento entre apropriar e produzir, há de significar instauração de condições para a qualidade educacional ser assumida em três perspectivas: (a) da primordialidade da atitude de produzir de modo inequívoco e opcionalmente empreendido, interiorizando o sentido emancipatório do conflito na esfera da subjetividade, a custos materiais insignificantes ou mediante apelo à imprescindibilidade $\quad(=$ institucionalidade alternativa) do produzir inequívoco que, inclusive, perfaz substrato animal da condição humana; (b) de ciência enquanto estrita instrumentalidade para que o caráter primordial da atitude assim produtiva encontre chance histórica de ocorrer; e, (c) de mudança ambiental - esta última perfazendo autossustentação dos egressos, assim como contribuição destes mesmos egressos a interações humanas sempre menos conflituosas e a desperdícios sempre menores no custeio do exercício das funções institucionais.

As demais hipóteses acabaram formuladas em uma perspectiva analítico-constitutiva da generalidade da anterior. Perfazem um conjunto e um subconjunto, este último de alcance mais instrumentalizante. 
Em potenciais antípodas da mesmice atitudinal e da funcionalidade desta ao vezo a-historicamente apropriativo, inequívoca alteridade de condutas tem tido seu próprio potencial represado por ausência de historicização da práxis do produzir enquanto racional-materialmente discernível do apropriar, apesar de que, ao longo da história, a prática forçosa desse produzir já tivesse sugerido a condição de utopia-de-referência à efetivação da alteridade em apreço.

Discernimento entre produzir e apropriar evoca senso natural-grupal de responsabilidade, a partir do substrato sensitivo-racional que é comum aos espécimes inequivocamente adultos, inclusive no contexto da vida animal: a conduta de gerar gratuitamente excedentes de meios de vida, por além do necessário à subsistência de quem os gera ou para atender as necessidades da prole, vale dizer, conduta operante em coerência com sustentabilidade também coletiva. (Perfazem a racional-materialidade do discernimento em apreço):

- exercer atividades parcialmente gratuitas ou gerar excedentes fora da propriedade da respectiva fonte tem sido uma espécie de tabu cultural, cuja autofundamentação se traduz por conduta humanamente tão custosa que sempre significou o alcance penoso de inequívoco trabalho, alcance cujo 
enfrentamento tem sido ambientalevolucionistamente postergado, até que ameaça à autossustentação pessoal-social se configure como fatalidade tempestivamente visível;

- o alcance humano da interação entre prole e progenitores tem conotação de propriedade, havendo como afirmar que a prole, até adquirir capacitação a atuar em grau de autossustentabilidade, exerce uma posse tácita do coletivo ao qual pertence, a par de que a extrapolação dessa posse, por além do período que é necessário e suficiente à efetivação do potencial de se autossustentar, não apenas coincide com o vezo a-historicamente apropriativo de atitudes pessoal-corporativas, como também denuncia omissão educacional à conta de alheamento profano-científico sobre esse mesmo vezo; e,

- acumulação de propriedades extrínsecas à pessoa atende a uma necessidade culturalmente instalada no tecido social e que corresponde àquela de estar apriormente garantido o atendimento das demais necessidades, à medida que estas não fazem sentido senão enquanto meramente instrumentalizadas como suporte metódico da historização do vezo apriormente apropriativo.

Esta, forçosa e/ou seduzidamente, fonte de gratuidade tem sido imprescindível "fundamento real" (artifício culturalmente soerguido) de uma sociabilidade 
cuja prevalência sempre "justificou", não apenas funções institucionais privilegiadamente remuneradas, como também conveniência em alhear-se ao significado da imprescindibilidade de existirem ocupações parcialmente gratuitas, "fundamento" no qual o sempre esteve enredado.

Ao se ter em conta a intangível opcionalidade em contribuir para a elucidação dessas hipóteses, custa admitir que elas deixem de ultrapassar a própria condição hipotética, dada a reciprocidade de coerência e de pertinência quanto ao caráter íntegro do todo ao qual se reportam. Desde os primeiros ensaios na pertinente formulação, emergiram mediadas pelo "paradigma da insustentabilidade coletiva" e eram colocadas na perspepctiva de constituírem fissuras no monólito da propriedade a se fazer presente no vezo metropolístico que, por força do próprio marco regulatório, perpassa o ensino superior brasileiro.

Assim, os resultados da pesquisa-ação suprem a necessidade ou o problema de escudar decisões no sentido de buscar inequivocação quanto a veraz qualidade e a precisa cientificidade da educação a ser promovida, até que as (alegadas) ciências da educação estejam disponíveis. 


\section{Considerações finais}

No perfil do egresso dos hodiernos sistemas educacionais, ainda continua sendo reproduzido o primitivismo de o indivíduo se omitir quanto a abraçar, generosamente, atividades relacionadas com a contínua construção do coletivo, pois, na ausência de sedução e/ou sujeitação a assumir responsabilidades, ele se dispensaria do esforço adicional que é imprescindível a tal construção. A alternativa a essa dispensa teria de incidir em ameaça de morte ou de ele não dispor da suficiência mínima de bem-estar que coincide com a pura e simples satisfação de estar vivo. A reprodução de tal primitivismo tem a ver, ao menos em hipótese, com determinada omissão educativa. Trata-se de não lhe ser evocada generosidade ao longo do processo de ensino e aprendizagem. Ao contrário, na atualidade, o (tido por) educando enfrenta o paradoxo de ser generoso para se capacitar a não mais o ser. Ao longo do que os educadores denominam formação, interesse é que lhe é despertado, para não dizer incutido.

Em contraponto, cabe admitir, também ao menos em hipótese, que a generosidade em abraçar atividades relacionadas com a contínua construção do coletivo tem como ser evocada, no sentido de contribuir com imprescindível ou institucional excesso gratuito sobre o beneficiar-se isoladamente.

Isolamento de indivíduo(s) e/ou de coletivo(s), mediante autocircunscrição em propriedades externas à pessoa, é o fenômeno pelo qual se desvela tal primitivismo. À medida que expansão populacional implica insuficiência de tais 
propriedades, acentua-se o problema de estas mesmas propriedades precisarem suplementar o parentesco enquanto garantia contra a emergência de riscos ao atendimento das necessidades humanas, imediato no caso das natural-básicas e mediato no caso da reprodução da própria espécie. Assim, expansão de propriedades torna-se obsessiva, sendo imediatistamente efetivada sempre que possível e/ou mediatamente desejada na circunstância de estar presentemente inalcançável. A relação entre carência de propriedades e desejo de as expandir ilimitadamente desanda na criação da escassez, ou seja, no fulcro gerador de reais-concretos inerentemente contraditórios e na possibilitação de a condição imaterial das meras representações destes contraditórios conformar o vazio que perfaz a contradição em si mesma, a absurdidade em construção.

Ruptura de tal primitivismo há de significar ultrapassagem da autocircunscrição em propriedades extrínsecas à pessoa, assim como do natural esgotamento do que tem sido mais familiar e/ou da interveniência de acentuadas estranhezas, ambos - esgotamento e interveniência - a decorrerem de ameaça de insustentabilidade coletiva imiscuída com expansão populacional.

Violência contra estranhos e/ou contra a natureza constitui sintoma de resistência a ultrapassar isolamento ou primitivismo, apesar da inserção de pessoas e de populações em coletivos sempre mais complexos. Quebrar tal resistência vem sendo implicação de se ter que produzir utilidades para intercâmbio material-comunicativo com outras pessoas e/ou populações.

As utilidades eram inicialmente encontradas prontas na natureza, mas, a partir de certa época, precisaram ser parcialmente aprontadas à base de intercâmbio orgânico com a natureza. Todavia, a relação entre o já pronto e a precisão 
de aprontar tem tido como se repetir na história da pessoa. Trata-se da ainda potencial ruptura com o primitivismo ou com a inércia de neste permanecer. Essa ruptura tem sido inevitável na esfera do coletivo, mas não tem ocorrido na esfera da subjetividade em cujos labirintos ainda resta incólume o traço mais decisivo do primitivismo. Este traço coincide com a reprodução de algo que vem tendo pouca ou nenhuma explicação na objetividade em que produzir se tornou imprescindível ou definitivamente institucional. Paradoxalmente, tem sido curioso que ainda não tenha despertado curiosidade a circunstância de o indivíduo nascer naturalmente ainda não propriamente produtivo e de esta sua inata condição não ter sido percebida e interpretada como naturalmente provisória e culturalmente autorreproduzida.

Tal paradoxalidade tem como se coadunar com outra, aquela de a pedagogia estar colonizada por conhecimentos de objetos de outros campos de atuação e de ela mesma não contar com objeto próprio, a menos que se entenda como forma das práticas didáticas e incida na mera presunção de se hegemonizar como "forma das formas" dessas mesmas práticas. Assim, não tem tido como deixar de vitimar-se à fragmentação do conhecimento e à disparidade de práticas didáticas.

Cabe então hipotetizar, ao menos isto, que, não só suprir carência de especificidade de objeto da pedagogia, como também prevenir colonização dessa carência por objetos fragmentados de outros campos de atuação, são objetivos simultaneamente realizáveis à base do objeto do que seja produzir de modo inequívoco e opcionalmente empreendido. Trata-se, ademais, de objeto que precisa mediar o alcance coletivo-adulto do ensino e o sentido individual-juvenil da aprendizagem, tornando-se, assim mediativamente, antídoto 
à falta de reciprocidade de coerência e de pertinência dos demais objetos quanto à integridade do conhecimento.

Por seu turno, a condição fragmentada dos conteúdos curriculares tem encontrado respaldo na cultural-civilizatória ideologização do caráter intangível da liberdade cujo exercício tem permanecido residualmente isolacionista ou primitivista, o que só continua possível porque tal persistência se encontra conveniente e injustamente ultrapassada no âmbito do coletivo. Mas, na esfera da subjetividade, ainda se acha em crônica insuficiência.

Sintoma que corrobora aquela carência de especificidade de objeto da pedagogia tem residido na circunstância de a ideia correspondente a produzir ainda não ter ultrapassado o senso comum ou permanecer indiferenciada em relação à ideia de apropriar, além de incidir no seu mais antipático objeto colonizante - a economia.

Um desdobramento daquela mediação do objeto do que seja propriamente produzir há de acabar sendo admissível à base de desestimulação de disputas por espaços de poder em contraponto com simultânea dinamização de congraçamento entre educadores. É que esse objeto tende a reverter tendência de os demais, correspondentes a aspectos da real-concreticidade dos campos de atuação humana, distanciarem-se entre si ao serem fragmentados como disciplinas ou tópicos destas. Assim, há de acabar confirmado que a fragmentação do saber seja consentânea com sociabilidade competitiva e que antídoto a esta fragmentação incida em alteridade de princípio determinativo das relações interpessoais.

Desequivocação junto à docência e inequivocação junto ao alunado, a respeito do que seja um produzir dialeticamente oposto à incontinência do apropriar, adentra alteridade 
institucional cuja emancipação se traduz na específica e inescapável autoridade de pedagogo. A vivência de tal emancipação não ultrapassa rito de passagem, pois a liberdade é valor intangível e caracteriza adultez humana. Por isso, cumpre, qualitativo-cientificamente, vir a ser exercida com precisa noção do próprio significado. Já produzir de modo inequívoco e opcionalmente empreendido, ainda que "pegando carona" na generosidade juvenil e perfazendo rito de passagem, virá a ser assumido à base de determinada interdisciplinaridade cujo enfrentamento pela docência adentra um inescapável dilema: irracionalidade subsumida ao oportunismo de estratégias até mesmo sobrevivenciais, ou então, questionamento da marxiana involuntariedade da inserção nas relações sociais, a começar por aquelas de produção de serviços educativos.

Resta qualitativamente ético-político que o primeiro teor desse dilema há de já estar ultrapassado, juntamente com o seu rol de implicações, a partir daquela da incidência em (auto)-avaliação reducionista que tem sido mediada por escalares de notas abstratas e que está a suceder o reducionismo compreendido pelo soldo devido à (auto)-sujeitação a gerar mais-valia, o qual, por seu turno, já sucedera a mítica (auto)justificação das castas sociais.

Paralelamente, o segundo teor, aquele do questionamento da marxiana involuntariedade, há de adentrar desequivocado ensino e inequívoca aprendizagem do sentido de ser pedagogo. Eis o desfecho do texto acima elaborado! Ousada e modestamente, os inescapáveis labirintos dessa elaboração foram percorridos, ao menos em reciprocidade de coerência e de pertinência quanto à íntegra individuação do fenômeno pedagógico, até que saída acabasse inferível nos próprios vazios, vale dizer, no modo de ser ausencial da gratuidade ou da alteridade institucional. E o desfecho faz jus ao objeto sob 
pesquisa-ação: educar adentra veraz e opcionalmente empreendido produzir.

Produção inequívoca e opcionalmente empreendida urge existir e este mesmo existir se apoia na própria ausência. Assim, a existência da pedagogia emancipada há de contar com a pesquisa-ação recém-exposta e a ser entendida enquanto começo - algo diverso de nada, por mínimo que ainda o precise ser.

O campo de atuação, com o qual a pedagogia guarda coerência e pertinência, torna-se vertente de problemas a exigirem programas de estudos especializados, assim como projetos de pesquisa nos níveis de pós-graduação "sctricto sensu" de mestrado e doutorado.

Abrem-se horizontes para a IES buscar seu futuro, a ser inclusive mais rapidamente antecipado mediante intercâmbio com outras que se encontrem em melhor situação, ou mais lentamente, se continuar abandonada à própria sorte, o que há de continuar a se constituir em oportunidade para persistir na sua autoafirmação com a autenticidade instigada pelo isolamento exogenamente determinado e endogenamente inaceitável.

Cumpre insistir na busca do universal nas particularizações, como saída de o que é propriamente universitário ser assumido na perspectiva antimetropolista. Porém, este objetivo há de se contrapor à artificialista intensificação da complexidade de coletivos humanos que, até o presente e em excesso, têm incidido em sociedades em que proliferam desigualdades políticas, desníveis de acesso a científico-tecnologia e disparidades econômicas.

Em busca de tal objetivo, torna-se inadiável propor postura antipredatória às instituições vigentes, a começar pelas 
educacionais. A estas cumpre assumir a condição de fontes de elucidação sobre alteridade de conduta.

Essa condição, por sua vez, não significa que o egresso de IES venha a ser incapaz de competir, se a tanto for vitimado pelas circunstâncias. Ao contrário, a competição será sempre "menos pior" a ele e ao próximo, porque tem conhecimento de causa sobre a razão de ela estar a persistir. O que há de caracterizar tal egresso será o próprio ajuizamento sobre o que seja produção. Há de assumir como absolutamente certo que tudo o que lhe importa, inequívoca e opcionalmente, é ser ou não ser produtivo. Assim, não será volúvel aos assédios das tentações para fetichizar objetos ilusórios.

A partir da FASB será assumido o veraz significado do que seja autoridade educacional. Professores e suas ambiências ocupacionais são, em alcance tanto natural quanto cultural, promotores da experiência de produzir de modo inequívoco e opcionalmente empreendido. Para tanto, cumpre que vivenciem tal produzir, verazmente ou ao menos enquanto rito de passagem.

Ademais, por inaudito que o precise ocorrer, instituições educacionais passam a se enxergar como exclusivas fontes de testemunho de que um egresso tenha demonstrado já entender e vivenciar o que seja inequivocação quanto a produzir. Tal testemunho há de emergir, por paralelo e informal que acabe tendo de acontecer, como alteridade de diplomação.

Não restam dúvidas de que tais atitudes antipredatórias serão prejulgadas utópicas, pois o que tem imperado é o "santo" (separado) espírito da sincrônica-topocentria, em cujos horizontes nada há de mudar. Por isso, urge começar sem alardes, ousada e modestamente. A inserção local e regional da "proposta pedagógica fasbiana" de educação está, 
talvez, a acontecer em condições que lhe sejam imprescindíveis. Então, ela há de fazer jus ao passado anti-isolacionista de Barreiras e do significado de persistir no aprofundamento do sentido atribuído ao caráter "produtivo" da atuação local de seus "coronéis". Local-regionalmente, a astronômica assimetria entre absurdidade em construção (inerente à fronteira científico-tecnológica de esgotamento dos cerrados, dos rios perenes e de outros recursos naturais regionais) e seminal geração de gratuidade (desde os pioneiros ribeirinhos, passando pelos meeiros-vaqueiros, pequenos lavradores e remeiros de saudosas barcas, até e enfim chegar a humildes e ousados educadores). Em suma, a educação a ser promovida há de ir ao encontro da histórica anuência ao intercâmbio materialcomunicativo, pela qual se projetou a cultura dos ribeirinhos fundadores de Barreiras, com seu atilado senso de enxergar e promover fissuras no monólito da propriedade. Urge que eles intuam que a gratuidade tem como se agigantar e explodir a bolha da escassez criada pela incontinência apropriativa. 


\section{Referências}

ABBAGNANO, N. Dicionário de filosofia. São Paulo: Martins Fontes, 2007.

ALMEIDA, J.L.V.; OLIVEIRA, E.M.; ARNONI, M.E.B. (Orgs.) Mediação dialética na educação escolar: teoria e prática. São Paulo: Edições Loyola, 2007.

ARISTÓTEleS. Política. São Paulo, SP: Martin Claret, 2007.

Metafísica: livro 1 e 2; Ética a Nicômacos; Poética. São Paulo: Abril Cultural, 1984. (Os pensadores).

BARBULES, N.C.; RICE, Z. Diálogo entre as diferenças: continuando a conversação. In: SILVA, T. T (Org.). Teoria educacional crítica em tempos pós-modernos. Porto Alegre, RS: Artes Médicas, 1993. p 173-204.

BERGAMO, P. The Collective Insustainability Paradigm. The International Journal of Environmental, Cultural, Economic \& Social Sustainability. V. 3. N. 6. p. 137-143.

BOTOMÉ, S.P. Pesquisa alienada e ensino alienante: o equívoco da extensão universitária. Petrópolis/RJ: Ed. Vozes, 1996. p. 27-29. 
BUENO, F. S. Grande dicionário etimológico-prosódico da língua portuguesa. São Paulo: LISA, 1988.

COMTE-SPONVILle, A. A filosofia. São Paulo: Martins Fonte, 2005.

CHAUÍ, M. A universidade em ruínas. In: TRINDADE, $H$. Universidade em ruínas: na república dos professores. 3 ed. Petrópolis, RJ: Editora Vozes / Rio Grande do Sul: CIPEDES, 1999a. p. 211-223.

A universidade operacional. REVISTA

ADUNICAMP, jun./1999b. p. 6-9.

CUNHA, L.A. Educação e desenvolvimento social no Brasil. Rio de Janeiro: Francisco Alves, 1978.

A universidade crítica: o ensino superior na República Populista. Rio de Janeiro: F. Alves, 1983.

A universidade reformanda. Rio de Janeiro: $F$. Alves, 1988.

. Qual universidade? São Paulo: Cortez, 1989.

DEMO, P. Função social da universidade e algumas considerações a partir da política social. Educação Brasileira, V. $1-$ N. $1-1^{\circ}$ Sem. Brasília, CRUB, 1978. s/n.

Avaliação qualitativa. São Paulo: Cortez : Autores Associados, 1987. 
1985.

Ciências sociais e qualidade. São Paulo: ALMED,

DIAS SOBRINHO, J. Concepção de universidade e de avaliação institucional. In: TRINDADE, Hélio. Universidade em ruínas: na república dos professores. 3 ed. Petrópolis, RJ: Editora Vozes / Rio Grande do Sul: CIPEDES, 1999. p. 149-169.

FERRY, L. O homem deus ou o sentido da vida. 2 ed. Rio de Janeiro: DIFEL, 2007, 82-91.

FREIRE, Paulo. Pedagogia da autonomia: saberes necessários à prática educativa. 23 Ed. Rio de Janeiro: Paz e Terra, 2002.

A educação na cidade. São Paulo: Cortez, 2005.

GASPARIN, J.L. Uma didática para a pedagogia histórico-crítica. 4 ed. Campinas, SP: Autores Associados, 2007.

GOERGEN, P. Pós-modernidade, ética e educação. Campinas, SP, Autores Associados, 2001.

HABERMAS, J. Conhecimento e interesse. Rio de Janeiro: Zahar, 1982.

Pensamento pós-metafísico: estudos filosóficos.

Rio de Janeiro: Tempo Brasileiro, 1990.

Direito e democracia: entre facticidade e validade.

2 ed. Rio de Janeiro: Tempo Brasileiro, 2003. 
HUISMAN, D. Dicionário dos filósofos. São Paulo: Martins Fonte, 2004.

KISILTAN, M.U; BAIN, W.J.; KANIZARES, M. A. (1993) Condições pós-modernas: repensando a educação pública. In: SILVA, T. T (Org.). Teoria educacional crítica em tempos pós-modernos. Porto Alegre/RS: Artes Médicas, 1993. p. 205-232.

KUBO,O.M.; BOTOMÉ, S.P. Ensino-Aprendizagem: uma interação entre dois processos comportamentais. INTERAÇÃO, Curitiba/PR: PUCPR, 2001, v. 5, p. 133172.

LESSA, S. Trabalho e proletariado no capitalismo contemporâneo. São Paulo: Cortez, 2007.

McLAREN, P. Pós-Modernismo, pós-colonialismo e pedagogia. In: SILVA, T. T. (Org.). Teoria educacional crítica em tempos pós-modernos. Porto Alegre/RS: Artes Médicas, 1993. p. 9-40.

MANACORDA, M. A. Marx e a pedagogia moderna. 2 ed. Campinas, SP: Edit. Alínea, 2007.

MARX, K. Prefácio à contribuição à crítica da economia política. In: MARX e ENGELS. Textos. São Paulo: Edições Sociais, 1977.

O Capital: crítica da economia política. 9 ed. São Paulo: DIFEL. 1984. L. 1. 


\section{Contribuição à crítica da economia política.}

São Paulo: Martins Fontes, 2003.

. e ENGELS, F. Obras escolhidas. Lisboa: Edições

"Avante"; Moscovo: Edições Progresso, 1982. T. I.

Obras escolhidas. Lisboa: Edições "Avante";

Moscovo: Edições Progresso, 1983. T. II

A ideologia alemã: $1^{\circ}$. Capítulo, seguido das

Teses sobre Feuerbach. São Paulo: Edit. MORAES, 1984.

Obras escolhidas. Lisboa: Edições "Avante”;

Moscovo: Edições Progresso, 1985. T. III

MEC/Conaes/Inep. Avaliação Externa de Instituições de Educação Superior: Diretrizes e Instrumento. Brasília/ DF: Conaes/Inep, 2005.

Diretrizes para a avaliação das instituições de Educação superior. Brasília/DF: Conaes/Sesu/Inep. s/d.

. Roteiro de autoavaliação institucional: orientações gerais. Brasília/DF, 2004.

MELLO, G. N. Magistério de $\mathbf{1}^{\mathbf{0}}$. Grau: da competência técnica a competência política. 12 ed. São Paulo: Cortez, 1998.

MÉSZÁROS, I. A educação para além do capital. São Paulo: Boitempo, 2005. 
MORROW, R.A. e TORRES, C.A. Jürgen Habermas, Paulo Freire e a pedagogia crítica: novas orientações para a Educação Comparada. In: TORRES, C.A. (Org.). Teoria crítica e sociologia política da educação. São Paulo: Cortez: Instituto Paulo Freire, 2003. p. 229-263.

MUNIZ, A. J. O. e FARIA, H. A. Teoria geral da administração: noções básicas. 4 ed. São Paulo: Atlas, 2001.

NOSELLA, P. Compromisso político e competência técnica: 20 anos depois. Educação e Sociedade. V. 26. n. 90 , Jan./Abr. 2005. p. 223-38.

NOVASKI, A. Fenomenologia: o método. PróProposições/Universidade Estadual de Campinas, Faculdade de Educação. Campinas, SP: v. 18, n. 1 (52), jan./ abr. 2007. p. 79-85.

NUNES, C. A. As origens da articulação entre filosofia e educação: matrizes conceituais e notas críticas sobre a paideia antiga. In: Lombardi, J.C. (Org). Pesquisa em educação: história, filosofia e temas transversais. Campinas, SP: Autores Associados: HISTEDBR: Caçador, SC: UnC, 1999a. p. 57-75.

A universidade entre a autonomia e a venalidade.

REVISTA ADUNICAMP, nov./1999b. p. 31-38.

. Educar para a emancipação. Florianópolis, SC:

Sophos, 2003a.

Filosofia, dialética e educação. In: Lombardi, J.C.

Globalização, pós-modernidade e educação: história, 
filosofia e temas transversais. Campinas/SP: Autores Associados, 2003b, p. 155-195.

\section{Platão e a dialética entre a filosofia do amor} e o amor da filosofia: um estudo pedagógico de ética sexual. Campinas, SP: FAE/UNICAMP, 2006.

e GAMBOA, S. Filosofia e Dialética: tópicos para uma retomada do debate sobre as tendências epistemológicas em educação. Revista de Educação - V. I. Nº 1 - Set./1998. Pirassununga/SP, Faculdade de Educação de Pirassununga. p. 81-99.

PALEARI, Giorgio. Religiões do povo: um estudo sobre aculturação. São Paulo: AM Edições, 1990.

PIMENTEL, A. (2007) Vygostky: uma abordagem histórico-cultural da educação infantil. In: OLIVEIRAFORMOZINHO, J., KISHIMOTO, T.M. e PINAZZA, M.A. Pedagogia da infância: dialogando com o passado - construindo o futuro. Porto Alegre, RS: Artmed. 2007. p. 219-248.

PISTRAK, M.M. Fundamentos da escola do trabalho. São Paulo: Expressão Popular, 2000.

PLATÃO. A República. São Paulo, SP: Martin Claret, 2007.

RIBEIRO, D. A universidade necessária. Rio de Janeiro: Paz e Terra, 1969. 
ROCHA, G. O Rio São Francisco: fator precípuo da existência do Brasil. 3 ed. São Paulo: Editora Nacional; [Brasília]: CODEVASF, 1983.

RUSSELL, B. História da filosofia ocidental. Brasília/ DF: Edit. UnB, 1982. II.

SÁNCHEZ GAMBOA, S.A.S. A dialética na pesquisa em educação: elementos de contexto. In: FAZENDA, I. (Org). Metodologia de pesquisa educacional. 4 ed São Paulo: Cortez, 1997. (Biblioteca da Educação, Série 1. V. II, p. 91-115.

. Pesquisa em educação: métodos e epistemologias. Chapecó, SC: Argos, 2007.

SANTOS, M. Pensando o espaço do homem. São Paulo: Hucitec, 1991.

SAVIANI, D. Educação: do senso comum à consciência filosófica. 16 ed. Campinas, SP: Autores Associados, 2004.

Pedagogia histórico-crítica: primeiras aproximações. 9 Ed. São Paulo: Cortez; Autores Associados, 2005.

A nova lei da educação: LDB: trajetória, limites e perspectivas. 10 ed. Campinas, SP: Autores Associados, 2006.

. Epistemologia e teoria da educação. Pró-

Proposições/Universidade Estadual de Campinas,

Faculdade de Educação. Campinas, SP: v. 18, n. 1 (52), jan./ abr. 2007a. p.15-27. 
Escola e democracia. Ed. 39. Campinas, S.P: Autores Associados, 2007b.

- (2007c) História das idéias pedagógicas no Brasil. Campinas, SP: Autores Associados, 2007.

SILVA, M.A. Intervenção e consentimento: a política educacional do Banco Mundial. Campinas, SP: Autores Associados : São Paulo: Fapesp, 2002.

SHAPIRO, S. O fim da esperança radical? O pós-modernismo e o desafio à pedagogia crítica. In: SILVA, T. T (Org.). Teoria educacional crítica em tempos pós-modernos. Porto Alegre/RS: Artes Médicas, 1993. p. 103-121.

TORRES, C. A. (Org.). Teoria crítica e sociologia da educação. São Paulo: Cortez: Instituto Paulo Freire, 2003.

WACHOWICZ, L. A. O método dialético na didática da educação superior. In: CASTANHO e CASTANHO. Temas e textos em metodologia do ensino superior. Campinas, SP: Papirus, 2001. p. 37-46.

WEBER, M. A ética protestante e o espírito do capitalismo. 3 ed. São Paulo: Pioneira, 1983.

WILLIAMS, B.A.O. Platão: a invenção da filosofia. São Paulo: Editora UNIESP, 2000. 


\section{Sobre o livro}

Este livro foi impresso na Gráfica Universitária da UEPB.

Formato: 14 × $20 \mathrm{~cm}$.

Tipologias utilizadas: Bembo Std 11pt / 13pt.

Papel: Apergaminhado $75 \mathrm{~g} / \mathrm{m}^{2}$ (miolo) e Cartão Supremo $250 \mathrm{~g} / \mathrm{m}^{2}$ (capa). 